\title{
The Pathoparasitology of Nonhuman Primates: A Review
}

\author{
JOHN D. TOFT, II
}

\section{Introduction}

Most people who have had more than cursory experience in the husbandry of nonhuman primate colonies will agree that parasitism is one of the most common disease entities that affects these animals. Numerous protozoal and metazoal genera have been described as infecting the members of all major nonhuman primate groups. Many of these are considered to be nonpathogenic, or at least their detrimental effects upon the host have yet to be eludicated. A large number, however, can produce lesions that result in serious debilitation and can create opportunities for secondary infections that may be fatal. This process appears to be exacerbated by the stress of capture and confinement.

This paper discusses the anatomic features of protozoan and metazoan parasitic infections of nonhuman primates. Since the paper is essentially a review of the literature, an extensive bibliography is included for those readers who wish to pursue the subject in greater detail. All tables in the text follow a published system [290]. Major nonhuman primate groups are classified according to a published taxonomy system [621]. Prosimians include the species in the families Tupaiidae; New World monkeys include the species in the families Callitrichidae and Cebidae; Old World monkeys include the species in the family Cercopithecidae; and the great apes include the species in the families Hylobatidae and Pongidae.

The numerous articles published previously that discuss the subject of nonhuman primate parasitology as a specific entity, or as a part of an overall discussion of general parasitology, systemic pathology, or the broad topic of nonhuman primate diseases, are outlined as follows: enteric and somatic protozoa [23, 72, 90 , $338,369,370,433,443,529,604]$; hemoprotozoa $[2,123,135,140,236,320$, $372,556,797,874,928]$; nematodes [650]; trematodes [147, 482]; cestodes [ 608]; acanthocephalans [770]; arthropods [92, 207, 281, 290, 302, 395, 405, 413, 457, 938]; pentastomids [788]; general parsitology [32, 339, 416, 427, 484, $487,497,499,528,530,531,791,810]$; systemic pathology [21, 97, 367, 429, $542,572,594,774,820,846]$; and nonhuman primate diseases [14, 34, 35, 112, $134,312,373,407,424,431,438,440,461,469,508,570,584,585,742,746$, 869].

In addition, there are many papers in the literature concerning parasitological surveys and parasite checklists for specific species of nonhuman primates. These 
are referenced as follows: rhesus monkey, Macaca mulatta $[1,220,434,435$, 447, 680, 716, 741, 859, 912]; cynomolgus monkey, Macaca fascicularis [1, 45, 362, 393, 763, 912]; pig-tail monkey, Macaca nemestrina [912]; bonnet monkey, Macaca radiata, [912]; stump-tail monkey, Macaca arctoides [912]; Barbary ape, Macaca sylvanus [91]; Formosan rock macaque, Macaca cyclopis [490, 494]; African green monkey, Cercopithecus sp. [518]; silvered leaf monkey, Presbytis cristatus [3, 658, 659, 660]; chacma baboon, Papio ursinus [336, 578]; yellow baboon, Papio cynocephalus [485, 497, 616]; olive baboon, Papio anubis, syn. P. doguera [486, 488, 611]; baboons, Papio sp. [1, 573, 609, 610, 626, 823]; gelada baboon, Theropithecus gelada [493]; tamarin, Saguinus fusciollis [148]; owl monkey, Aotus trivirgatus [895]; squirrel monkey, Saimiri sciureus [584]; New World monkeys [121, 437, 492]; slender loris, Loris tardigradus [477]; tarsiers, Tarsius bancanus [61, 387]; chimpanzee, Pan sp. [284, 491, 613, 863]; and laboratory primates $[712,764,911,912]$.

References for additional reading on nonhuman primate parasitology, associated lesions, and related subjects outside the scope of this paper are as follows: pathology [290, 406, 427, 428, 742, 791]; necropsy techniques [910]; recognition of parasites [607]; comparative parasitology [127]; experimental parasitology [483, 643]; identification of parasitic eggs [421]; identification of parasites in tissue sections [128, 307, 848]; parasitic zoonoses [417, 432, 529, 931]; and parasite control [155].

\section{Protozoan Parasites}

\section{Flagellates}

The enteric flagellates and hemoflagellates described in nonhuman primates are listed in Table 45.1. All of the enteric flagellates are considered nonpathogenic except Giardia lamblia, which has been reported to cause diarrhea in monkeys $[290,742]$. The ability of Giardia to cause disease is controversial, however, and the factors that govern its pathogenicity are not completely understood [529]. The majority of the hemoflagellates reported from nonhuman primates are also considered to be nonpathogenic. An exception is Trypanosoma cruzi, which is an important pathogen and is the cause of Chagas disease in humans. Many species of wild and domestic animals have been found to be infected with this parasite, including nonhuman primates, and it is speculated that most mammals are susceptible. In addition, since it is an important pathogen of humans, it has potentially serious public health implications and will be discussed in detail below.

\section{South American Trypanosomiasis (Chagas Disease)}

The cause of this disease, the hemoflagellate Trypanosoma cruzi, is distributed throughout South and Central America with extension into the southern and southwestern regions of the United States. Dr. Chagas made the original description of this parasite in Callithrix penicillata from Brazil [23, 109]. He also reported the first case of natural infection in the squirrel monkey [110]. Natural T. cruzi infection has been reported from numerous New World primate species (squirrel monkeys, marmosets, spider monkeys, cebus monkeys, and uakaris) [6, $20,25,32,88,159,160,212,219,290,511,559,812]$. Trypanosoma cruzi also 
TABLE 45.1. Parasitic flagellates described from nonhuman primates.

\begin{tabular}{|c|c|c|c|c|c|c|}
\hline $\begin{array}{c}\text { Parasite } \\
\text { genus-species }\end{array}$ & $\begin{array}{l}\text { Location in } \\
\text { host }\end{array}$ & $\begin{array}{l}\text { Pro- } \\
\text { simians }\end{array}$ & $\begin{array}{l}\text { New World } \\
\text { monkeys }\end{array}$ & $\begin{array}{l}\text { Old World } \\
\text { monkeys }\end{array}$ & $\begin{array}{l}\text { Great } \\
\text { apes }\end{array}$ & References \\
\hline \multicolumn{7}{|l|}{ Hemoflagellates } \\
\hline Trypanosoma & & & & & & \\
\hline cruzi & $\begin{array}{l}\text { Blood, RE cells, } \\
\text { muscle, heart, } \\
\text { other tissues }\end{array}$ & & $\mathrm{x}$ & $\mathrm{X}$ & $\mathrm{X}$ & $\begin{array}{l}6,20,23,25, \\
32,88,109, \\
110,159,160, \\
212,219,290, \\
511,559,560, \\
782,789,812\end{array}$ \\
\hline $\begin{array}{c}\text { Trypanosoma } \\
\text { sanmartini }\end{array}$ & Blood & & $\mathrm{X}$ & & & $\begin{array}{l}23,212,290 \\
324\end{array}$ \\
\hline $\begin{array}{c}\text { Trypanosoma } \\
\text { minasense }\end{array}$ & Blood & & $\mathrm{X}$ & & & $\begin{array}{l}23,109,159 \\
161,212,290 \\
559,560,728\end{array}$ \\
\hline $\begin{array}{l}\text { Trypanosoma } \\
\text { rangeli }\end{array}$ & Blood & & $\mathrm{X}$ & & & $\begin{array}{l}23,212,290 \\
342,343,528\end{array}$ \\
\hline $\begin{array}{l}\text { Trypanosoma } \\
\text { saimirii }\end{array}$ & Blood & & $\mathrm{X}$ & & & $\begin{array}{l}23,162,212 \\
290,728\end{array}$ \\
\hline $\begin{array}{l}\text { Trypanosoma } \\
\text { diasi }\end{array}$ & Blood & & $\mathrm{X}$ & & & $\begin{array}{l}23,162,163 \\
212,290\end{array}$ \\
\hline $\begin{array}{c}\text { Trypanosoma } \\
\text { lambrechti }\end{array}$ & Blood & & $\mathrm{X}$ & & & $\begin{array}{l}23,166,212 \\
559,560\end{array}$ \\
\hline $\begin{array}{l}\text { Trypanosoma } \\
\text { primatum }\end{array}$ & Blood & & & & $\mathrm{X}$ & $\begin{array}{l}23,72,218 \\
290,713,778 \\
779,936\end{array}$ \\
\hline $\begin{array}{c}\text { Trypanosoma } \\
\text { brucei }\end{array}$ & Blood & & & $\mathrm{X}$ & & 23 \\
\hline $\begin{array}{r}\text { Trypanosoma } \\
\text { perodictici }\end{array}$ & Blood & $\mathrm{X}$ & & & & $\begin{array}{l}23,37,40 \\
41,72,388 \\
713,779\end{array}$ \\
\hline $\begin{array}{c}\text { Trypanosoma } \\
\text { irangiense }\end{array}$ & Blood & $\mathrm{X}$ & & & & $\begin{array}{l}23,39,41, \\
388\end{array}$ \\
\hline Trypanosoma sp. & Blood & $\mathrm{X}$ & & & & $\begin{array}{l}136,205,213, \\
354,357,496, \\
620,933\end{array}$ \\
\hline \multicolumn{7}{|l|}{ Enteric flagellates } \\
\hline $\begin{array}{l}\text { Trichomitus } \\
\text { wenyoni }\end{array}$ & Cecum, colon & & & $\mathrm{X}$ & & $90,290,898$ \\
\hline $\begin{array}{l}\text { Trichomonas } \\
\text { buccalis }\end{array}$ & Mouth & & & $\mathrm{X}$ & & 371,742 \\
\hline $\begin{array}{l}\text { Trichomonas } \\
\text { tenax }\end{array}$ & Mouth & & & $\mathrm{X}$ & $\mathrm{X}$ & $\begin{array}{l}90,290,371 \\
391,529\end{array}$ \\
\hline $\begin{array}{l}\text { Trichomonas } \\
\text { foetus }\end{array}$ & Intestine & $\mathrm{X}$ & & & & 61 \\
\hline $\begin{array}{l}\text { Trichomonas } \\
\text { hominis }\end{array}$ & Intestine & & & & $\mathrm{X}$ & 491,494 \\
\hline Trichomonas sp. & Intestine & $\mathrm{X}$ & $\mathrm{X}$ & & & $168,387,895$ \\
\hline $\begin{array}{l}\text { Pentatrichomonas } \\
\text { hominis }\end{array}$ & Cecum, colon & & $\mathrm{X}$ & $\mathrm{X}$ & $\mathrm{X}$ & $\begin{array}{l}290,369,371, \\
529,680\end{array}$ \\
\hline $\begin{array}{l}\text { Enteromonas } \\
\text { hominis }\end{array}$ & Cecum & & & $\mathrm{X}$ & $\mathrm{X}$ & $\begin{array}{l}90,290,491 \\
530,712\end{array}$ \\
\hline $\begin{array}{c}\text { Retortamonas } \\
\text { intestinalis }\end{array}$ & Cecum & & & $\mathrm{X}$ & $\mathrm{X}$ & $\begin{array}{l}90,290,529 \\
530\end{array}$ \\
\hline
\end{tabular}

(Continued) 
TABLE 45.1. (Continued).

\begin{tabular}{|c|c|c|c|c|c|c|}
\hline $\begin{array}{c}\text { Parasite } \\
\text { genus-species }\end{array}$ & $\begin{array}{l}\text { Location in } \\
\text { host }\end{array}$ & $\begin{array}{c}\text { Pro- } \\
\text { simians }\end{array}$ & $\begin{array}{l}\text { New World } \\
\text { monkeys }\end{array}$ & $\begin{array}{l}\text { Old World } \\
\text { monkeys }\end{array}$ & $\begin{array}{l}\text { Great } \\
\text { apes }\end{array}$ & References \\
\hline $\begin{array}{l}\text { Chilomastix } \\
\text { mesnili }\end{array}$ & Cecum, colon & & $\mathrm{X}$ & $\mathrm{X}$ & $\mathrm{X}$ & $\begin{array}{l}90,290,369, \\
371,485,491, \\
530,609,654, \\
680,712\end{array}$ \\
\hline $\begin{array}{l}\text { Chilomastix } \\
\text { tarsii }\end{array}$ & Intestine & $\mathrm{X}$ & & & & $61,387,685$ \\
\hline Chilomastix sp. & Intestine & & $\mathrm{X}$ & & & 885 \\
\hline Hexamita pitheci & Cecum, colon & & & $\mathrm{X}$ & $\mathrm{X}$ & $156,290,529$ \\
\hline Hexamita sp. & Cecum & & & $\mathrm{X}$ & $\mathrm{x}$ & $\begin{array}{l}90,290,369 \\
896\end{array}$ \\
\hline Giardia lamblia & $\begin{array}{l}\text { Anterior sm. } \\
\text { intestine }\end{array}$ & & $\mathrm{X}$ & $\mathrm{X}$ & $\mathrm{X}$ & $\begin{array}{l}90,290,491 \\
529,530,742\end{array}$ \\
\hline Giardia sp. & Intestine & & $\mathrm{X}$ & & & 168,895 \\
\hline
\end{tabular}

has been reported from Old World monkeys that originated in Asia (Macaca sp. and rhesus monkeys) [23, 290, 789, 791] and great apes (gibbon) [782]. Despite the reports in nonhuman primates other than New World monkeys, the question of whether or not $T$. cruzi exists outside the Western Hemisphere remains unanswered. A review of some of the earlier reports of this parasite in Asian monkeys concluded that infection was most probably acquired after the animals were in captivity [23]. Two additional cases have been reported involving rhesus monkeys that were members of colonies which were part of long-term research projects. Infection in these monkeys was considered also to have occurred during captivity, especially since they were housed outdoors in an endemic area of the United States [132, 436].

Two forms of $T$. cruzi are found in susceptible animals. The trypomastigote (trypanosomal) form occurs in the blood. The amastigote (leishmanial) form is found in groups in the cells of skeletal and cardiac muscle, the reticuloendothelial system, and other tissues. The life cycle is indirect with species of several genera of triatomid bugs belonging to the family Reduviidae (cone-nose bugs, assassin bugs, or kissing bugs) as biological vectors. For a detailed description of the morphology and life cycle of this parasite, the reader is referred to the following references: $290,528,530$, and 791 .

Infection with $T$. cruzi causes rather nonspecific clinical signs [290]. Generalized edema without necrosis or hemorrhage is said to be common. Anemia, hepatosplenomegaly, and lymphadenitis also can occur [290, 791]. Depression, anorexia, weight loss, and dehydration were seen in the case involving the gibbon [782]. Electrocardiographic patterns consistent with that of right bundle branch block are reported from the cebus monkey [88]. Also, a case of intrauterine death from congenital trypanosomiasis in marmosets has been reported [549].

The lesion mentioned most frequently in all of the naturally occurring cases of T. cruzi infection in nonhuman primates is myocarditis, which results in the destruction of myocardial fibers $[88,290,511,782]$. Histopathologically, the infected myocardium contains numerous, randomly scattered, cystic structures of varying sizes, occupying individual myocardial fibers. These structures are pseudocysts that contain many individual circular to oval-shaped organisms from 
1.5 to $4 \mu$ in diameter, with a central nucleus and a prominent bar-shaped structure (kinetoplast). The kinetoplast is an intracellular organelle that is diagnostic for this parasite and aids in differentiating it from the intracellular forms of sarcocystis and toxoplasmosis. These organisms can also be seen filling the cytoplasm of large mononuclear reticuloendothelial (RE) cells, some of which can be multinucleated and have the characteristics of giant cells. Degenerating pseudocysts elicit a focal mononuclear cell inflammatory response, and there may be mild dystrophic mineralization of individual myocardial fibers in some of these areas [436].

The diagnosis of $T$. cruzi can be made by demonstrating and identifying the parasites in blood or other body fluids or in histological sections. Thin and thick blood smears should be stained with Giemsa preparations and examined for the presence of trypanosomes. Animal inoculation and xenodiagnosis can also be used to allow the organism to complete its life cycle. Xenodiagnosis involves the examination of known vectors for trypanosomes after they have been allowed to feed on suspected hosts [23, 290].

Because $T$. cruzi can cause serious disease in humans, all people involved with the care and use of nonhuman primates should exercise extreme care to avoid exposure either by accidental inoculation with trypanosomes or by contamination of mucous membranes or skin with infected material. This should be especially true for those persons working with New World monkeys or with any nonhuman primate maintained in an endemic area in the United States [23, 290].

\section{Sarcodines (Ameba)}

The parasitic sarcodines described in nonhuman primates are listed in Table 45.2. All are considered nonpathogenic except Dientamoeba, which sometimes can be pathogenic, and Entamoeba histolytica, which can cause severe enteric disease in humans and nonhuman primates. Entamoeba histolytica will be discussed in detail.

\section{AMEBIASIS}

The cause of this disease, Entamoeba histolytica, has a world-wide distribution and has been reported in New World monkeys (spider monkeys, cebus monkeys, woolly monkeys, howler monkeys, squirrel monkeys, and marmosets), Old World monkeys (rhesus monkeys, pig-tailed macaques, bonnet macaques, cynomolgus monkeys, colobus monkeys, proboscis monkeys, African green monkeys, baboons, and langurs), and the great apes (gibbons, orangutans, and chimpanzees) $[10,38,51,92,172,207,222,285,290,299,329,330,369,376,423$, $437,445,486,491-494,544,545,588,599,601,661,712,742,746,747,769$, $791,863,929]$. Infection is said to be common in Old World monkeys but uncommon or rare in New World monkeys obtained from their natural habitat [200, $742,791,869$ ]. Young monkeys and New World monkeys are reported to sustain more severe lesions from infection with this parasite $[46,90,207,223,704$, $742,869]$.

The morphology of this parasite has been discussed $[90,182,290,389,529$, $530,748,791]$. Two races of $E$. histolytica are recognized, separated on the basis of size. The pathogenic race is the larger form; the trophozoites measure $20-30$ 
TABLE 45.2. Parasitic sarcodines described from nonhuman primates.

\begin{tabular}{|c|c|c|c|c|c|c|}
\hline $\begin{array}{c}\text { Parasite } \\
\text { genus-species }\end{array}$ & $\begin{array}{l}\text { Location in } \\
\text { host }\end{array}$ & $\begin{array}{l}\text { Pro- } \\
\text { simians }\end{array}$ & $\begin{array}{l}\text { New World } \\
\text { monkeys }\end{array}$ & $\begin{array}{l}\text { Old World } \\
\text { monkeys }\end{array}$ & $\begin{array}{l}\text { Great } \\
\text { apes }\end{array}$ & References \\
\hline \multicolumn{7}{|l|}{ Ameba } \\
\hline $\begin{array}{l}\text { Entamoeba } \\
\quad \text { histolytica }\end{array}$ & Cecum, colon & & $\mathrm{X}$ & $\mathrm{X}$ & $\mathrm{X}$ & $\begin{array}{l}3,10,38,90, \\
168,172,207, \\
222,285,290, \\
300,329,330, \\
339,369,485, \\
486,487,491, \\
493,494,529, \\
530,588,599, \\
601,610,611, \\
616,654,661, \\
665,684,686, \\
687,712,742, \\
769,791,829, \\
863,868,869, \\
903,939\end{array}$ \\
\hline $\begin{array}{l}\text { Entamoeba } \\
\quad \text { hartmanni }\end{array}$ & Cecum, colon & & & $\mathrm{X}$ & $\mathrm{X}$ & $\begin{array}{l}57,90,290, \\
485,491,494, \\
529,530,611 \\
616\end{array}$ \\
\hline Entamoeba coli & Cecum, colon & & & $\mathrm{X}$ & $\mathrm{X}$ & $\begin{array}{l}90,168,290, \\
485,486,487, \\
491,493,494, \\
529,530,578, \\
616,654,680, \\
712,741,863\end{array}$ \\
\hline $\begin{array}{c}\text { Entamoeba } \\
\text { chattoni }\end{array}$ & Cecum, colon & & & $\mathrm{X}$ & & $\begin{array}{l}90,290,444, \\
445,485,491 \\
529,530,616\end{array}$ \\
\hline $\begin{array}{l}\text { Entamoeba } \\
\text { gingivalis }\end{array}$ & Mouth & & & $\mathrm{X}$ & $\mathrm{X}$ & $\begin{array}{l}90,290,371 \\
529,530,742\end{array}$ \\
\hline $\begin{array}{l}\text { Entamoeba } \\
\text { polecki }\end{array}$ & Cecum, colon & & & & $\mathrm{X}$ & $491,494,611$ \\
\hline Entamoeba sp. & Cecum, colon & & $\mathrm{X}$ & $\mathrm{X}$ & $\mathrm{X}$ & $\begin{array}{l}486,487,491, \\
494,573,578, \\
895\end{array}$ \\
\hline $\begin{array}{r}\text { Iodamoeba } \\
\text { buetschlii }\end{array}$ & Cecum, colon & & $\mathrm{X}$ & $\mathrm{X}$ & $\mathrm{X}$ & $\begin{array}{l}90,207,290, \\
369,371,485, \\
486,487,493, \\
494,529,530, \\
553,611,616, \\
712,897\end{array}$ \\
\hline $\begin{array}{c}\text { Iodamoeba } \\
\text { wallacei }\end{array}$ & Intestine & & & $\mathrm{X}$ & & 719 \\
\hline Iodamoeba sp. & Cecum, colon & & $\mathrm{X}$ & $\mathrm{X}$ & & $\begin{array}{l}493,494,573, \\
578,895\end{array}$ \\
\hline Endolimax nana & Cecum, colon & & $\mathrm{x}$ & $\mathrm{X}$ & $\mathrm{X}$ & $\begin{array}{l}90,207,290, \\
369,371,485, \\
486,487,493 \\
494,529,530, \\
553,611,616, \\
654,712,741\end{array}$ \\
\hline
\end{tabular}


TABLE 45.2. (Continued).

\begin{tabular}{|c|c|c|c|c|c|c|}
\hline $\begin{array}{c}\text { Parasite } \\
\text { Genus-species }\end{array}$ & $\begin{array}{l}\text { Location in } \\
\text { host }\end{array}$ & $\begin{array}{l}\text { Pro- } \\
\text { simians }\end{array}$ & $\begin{array}{l}\text { New World } \\
\text { monkeys }\end{array}$ & $\begin{array}{l}\text { Old World } \\
\text { monkeys }\end{array}$ & $\begin{array}{c}\text { Great } \\
\text { apes }\end{array}$ & References \\
\hline $\begin{array}{l}\text { Endolimax sp. } \\
\text { Dientamoeba }\end{array}$ & Cecum, colon & & $\mathrm{X}$ & & & 895 \\
\hline fragilis & Cecum, colon & & & $\mathrm{X}$ & & $\begin{array}{l}90,290,371, \\
467,486,487, \\
529,530\end{array}$ \\
\hline
\end{tabular}

$\mu \mathrm{m}$ in diameter. The smaller nonpathogenic race has trophozoites that measure 12-15 $\mu \mathrm{m}$. Only the pathogenic organisms ingest red blood cells; the presence of erythrocytes within trophozoites is helpful in distinguishing pathogenic from nonpathogenic amebae. Cyst forms are $10-20 \mu \mathrm{m}$ in diameter and contain four nuclei and rodlike chromatin bodies.

These organisms reproduce by binary fission [90, 290, 530]. Prior to producing the cyst form, the amebae become round and small. A cyst wall is formed; the nucleus divides twice, resulting in four small nuclei. These nuclei divide upon rupture of the cyst wall. Thus, each original organism separates into eight small amebae. Each of these in turn develops into a trophozoite.

Infection with $E$. histolytica produces mild clinical signs or none at all. There is a great variability in virulence among strains of organisms [90, 290, 529, 791]. Pathogenicity is affected by the host species infected, the nutritional status of the host, environmental factors, and the bacterial flora present in the gastrointestinal tract $[90,290,529,567,791]$. Entamoeba histolytica usually lives in the intestinal lumen where it is nonpathogenic [529]. Only when it invades the mucosa does it become pathogenic and may lead to amebic dysentery [529]. Clinically, affected animals show the following signs: lethargy, weakness, dehydration, anorexia, vomiting, and severe diarrhea that may or may not be hemorrhagic or catarrhal $[90,223,290,379,385,461,530,588,665,704,829,868,869,890]$. The gross and microscopic lesions associated with amebiasis in nonhuman primates have been described $[57,60,90,290,300,461,588,665,704,742,791$, $829,869]$. At necropsy, a mild to severe necroulcerative colitis can be seen. Entamoeba histolytica trophozoites can be found in wet smears from material from the colon of clinically ill animals or from the colonic contents overlying the lesions seen at necropsy [461]. Histologically, the colonic mucosa is necrotic and ulcerated down to the level of the muscularis mucosae; typical flask-shaped ulcers may be seen. These ulcers can be as small as a few millimeters or may become large and confluent and involve extensive areas of the colon. Trophozoites may be seen in or adjacent to the ulcers. Often, the host response is minimal unless secondary bacterial invasion has occurred [290, 461, 704, 791]. Extensive hemorrhage with neutrophilic and mononuclear inflammatory cell infiltrates has been described in lesions from New World monkeys [461]. Gastric amebiasis and death resulting from infection with $E$. histolytica has been reported in the silver leaf monkey, douc langurs, proboscis monkey, and colobus monkey [299, 330, 544, 545, 601, 661]. Some trophozoites may enter lymphatic channels or even the venules of the mesenteric vasculature. Most are filtered by the regional lymph nodes; a few, however, may be carried to distant parts of the 
body where they can produce the so-called amebic abscesses, particularly in the liver, lungs, or central nervous system [290, 300, 588, 665, 791]. Fatal amebiasis with abscess formation has been reported in a baboon [300], a chimpanzee [588], an orangutan [665], a group of spider monkeys [10], douc langurs [299], and several colobus monkeys [299, 544, 545].

The diagnosis of amebiasis depends upon the microscopic recognition of the causative organisms in the feces or in intimate association with typical lesions. These organisms are also common as nonpathogenic commensals in the digestive tract of nonhuman primates. Their presence in the feces of animals with clinical signs is not definitive evidence that protozoa are the cause of the gastrointestinal disease $[290,530,791]$. Wet-mount preparations may be used to examine the feces for trophozoites. This requires a fresh sample that must be placed immediately in a saline or buffer solution and examined while the preparation is still warm. The movement of the organisms can be seen. Entamoeba histolytica makes the most obvious kinds of progressive movement of all the intestinal amebae. Smears may be stained with Lugol's iodine solution, which identifies the nuclei and stains glycogen. Smears also may be fixed in Schaudinn's fluid and stained with Heidenhain's iron hematoxylin $[90,791]$. Nuclear morphology can be used to distinguish pathogenic $E$. histolytica from nonpathogenic species [146].

Entamoeba histolytica causes amebic dysentery in humans; therefore, this organism in nonhuman primates poses a serious potential public health problem. The disease has been transmitted from laboratory primates to humans [48, 329]. These primates should be considered potential sources of infection, and proper care should be exercised in all phases of their management.

\section{Sporozoans and Neosporans}

The parasitic sporozoans and neosporans described from nonhuman primates are listed in Table 45.3. Infection with the coccidian parasites is considered essentially innocuous; there are no known lesions or diseases associated with their presence in the nonhuman primate gastrointestinal tract. Since Cryptosporidium sp. has been described recently in the gastrointestinal tract of monkeys, it will be discussed in greater detail. In addition, the malarial parasites, toxoplasmasids (sarcocystis and toxoplasma), piroplasmids (babesia and entopolypoides), and neosporins (encephalitozoon) will be discussed in detail.

\section{CRYPTOSPORIDIOSIS}

This disease, caused by the coccidian parasite Cryptosporidium, has been reported in the digestive tract of the rhesus monkey [138, 472], cynomolgus monkey, and bonnet monkey [906]. In one study, the organisms were seen in the epithelium of the common bile duct, the intrahepatic and pancreatic ducts, and the gallbladder of one monkey [472]. Histologic changes consisted of epithelial hyperplasia and mucosal inflammation. In another study, cryptosporidial organisms were found in the small-intestinal epithelium of seven rhesus monkeys and in both the small- and large-intestinal epithelium of one infant monkey. There were no lesions associated with the organisms in any of the monkeys except the infant. In this infant, the changes were characterized by atrophy of villi associated with many parasites in the brush border of the epithelium lining the villi and intestinal crypts [138]. 
TABLE 45.3. Parasitic sporozoans and neosporans described from nonhuman primates.

\begin{tabular}{|c|c|c|c|c|c|c|}
\hline $\begin{array}{c}\text { Parasite } \\
\text { genus-species }\end{array}$ & $\begin{array}{l}\text { Location in } \\
\text { host }\end{array}$ & $\begin{array}{l}\text { Pro- } \\
\text { simians }\end{array}$ & $\begin{array}{l}\text { New World } \\
\text { monkeys }\end{array}$ & $\begin{array}{l}\text { Old World } \\
\text { monkeys }\end{array}$ & $\begin{array}{l}\text { Great } \\
\text { apes }\end{array}$ & References \\
\hline \multicolumn{7}{|c|}{ Coccidian parasites } \\
\hline Eimeria galago & Intestine & $\mathrm{X}$ & & & & $90,290,678$ \\
\hline Eimeria lemuris & Intestine & $\mathrm{X}$ & & & & $90,290,678$ \\
\hline Eimeria otolicni & Intestine & $\mathrm{X}$ & & & & $90,290,678$ \\
\hline $\begin{array}{l}\text { Eimeria } \\
\quad \text { pachylepyron }\end{array}$ & Intestine & $\mathrm{X}$ & & & & 139 \\
\hline Eimeria tupaiae & Intestine & $\mathrm{X}$ & & & & 604 \\
\hline Eimeria modesta & Intestine & $\mathrm{X}$ & & & & 604 \\
\hline $\begin{array}{l}\text { Eimeria } \\
\quad \text { ferruginea }\end{array}$ & Intestine & $\mathrm{X}$ & & & & 604 \\
\hline Eimeria sp. & Intestine & $\mathrm{x}$ & & & & 168,387 \\
\hline $\begin{array}{l}\text { Isopora } \\
\quad \text { arctopitheci }\end{array}$ & Intestine & & $\mathrm{X}$ & & & $\begin{array}{l}90,290,377 \\
378,727\end{array}$ \\
\hline Isopora callimico & Intestine & & $\mathrm{X}$ & & & 217,400 \\
\hline Isopora papionis & Intestine & & & $\mathrm{X}$ & & 576,578 \\
\hline Isopora sp. & Intestine & $\mathrm{X}$ & & & $\mathrm{x}$ & $\begin{array}{l}90,290,485 \\
678,722\end{array}$ \\
\hline $\begin{array}{l}\text { Cryptosporidium } \\
\text { sp. }\end{array}$ & Intestine & & & $\mathrm{x}$ & & $\begin{array}{l}138,472,791 \\
906\end{array}$ \\
\hline Klossiella sp. & Kidney & $\mathrm{X}$ & & & & 97,776 \\
\hline $\begin{array}{l}\text { Haemogregarina } \\
\text { cynomolgi }\end{array}$ & Blood & & & $\mathrm{X}$ & & $\begin{array}{l}54,290,505 \\
525,899\end{array}$ \\
\hline \multicolumn{7}{|c|}{ Piroplasmasid parasites } \\
\hline Babesia pitheci & Erythrocytes & & & $\mathrm{X}$ & & $\begin{array}{l}23,290,315 \\
385,386,449 \\
738,837\end{array}$ \\
\hline Babesia sp. & Erythrocytes & $\mathrm{X}$ & & & & 72 \\
\hline $\begin{array}{l}\text { Entopolypoides } \\
\text { macaci }\end{array}$ & Erythrocytes & & & $\mathrm{X}$ & & $\begin{array}{l}23,269,290 \\
332,363,485 \\
564,565,596\end{array}$ \\
\hline Theileria cellii & Erythrocytes & & & $\mathrm{X}$ & & $98,99,290$ \\
\hline \multicolumn{7}{|l|}{ Malarial parasites } \\
\hline $\begin{array}{l}\text { Plasmodium } \\
\text { cynomolgi }\end{array}$ & Erythrocytes & & & $\mathrm{x}$ & & $\begin{array}{l}70,143,180 \\
236,239,243 \\
290,316,415 \\
563,602,702 \\
772,773\end{array}$ \\
\hline $\begin{array}{l}\text { Plasmodium } \\
\text { knowlesi }\end{array}$ & Erythrocytes & & & $\mathrm{X}$ & & $\begin{array}{l}80,126,243, \\
290,318,466 \\
502,773,797 \\
925\end{array}$ \\
\hline $\begin{array}{l}\text { Plasmodium inui } \\
\text { syn. }(P . \text { shortti) }\end{array}$ & Erythrocytes & & & $\mathrm{x}$ & & $\begin{array}{l}70,71,186, \\
236,237,290, \\
353,399,415, \\
502,795,796, \\
816\end{array}$ \\
\hline $\begin{array}{l}\text { Plasmodium } \\
\text { coatneyi }\end{array}$ & Erythrocytes & & & $\mathrm{X}$ & & $\begin{array}{l}236,240,241, \\
244,290,561, \\
658,660,662, \\
881\end{array}$ \\
\hline Plasmodium fieldi & Erythrocytes & & & $\mathrm{X}$ & & $\begin{array}{l}236,242,290 \\
374,881\end{array}$ \\
\hline $\begin{array}{l}\text { Plasmodium } \\
\text { gonderi }\end{array}$ & Erythrocytes & & & $\mathrm{X}$ & & $\begin{array}{l}68,290,322, \\
733\end{array}$ \\
\hline
\end{tabular}


TABLE 45.3. (Continued).

\begin{tabular}{|c|c|c|c|c|c|c|}
\hline $\begin{array}{c}\text { Parasite } \\
\text { genus-species }\end{array}$ & $\begin{array}{l}\text { Location in } \\
\text { host }\end{array}$ & $\begin{array}{l}\text { Pro- } \\
\text { simians }\end{array}$ & $\begin{array}{l}\text { New World } \\
\text { monkeys }\end{array}$ & $\begin{array}{l}\text { Old World } \\
\text { monkeys }\end{array}$ & $\begin{array}{l}\text { Great } \\
\text { apes }\end{array}$ & References \\
\hline $\begin{array}{l}\text { Plasmodium } \\
\text { fragile }\end{array}$ & Erythrocytes & & & $\mathrm{X}$ & & $180,290,703$ \\
\hline $\begin{array}{l}\text { Plasmodium } \\
\text { siminovale }\end{array}$ & Erythrocytes & & & $\mathrm{X}$ & & $180,181,290$ \\
\hline Plasmodium sp. & Erythrocytes & & & $\mathrm{X}$ & & 236,290 \\
\hline $\begin{array}{l}\text { Plasmodium } \\
\text { brasilianum }\end{array}$ & Erythrocytes & & $\mathrm{X}$ & & & $\begin{array}{l}165,206,211, \\
290,337,690, \\
835\end{array}$ \\
\hline $\begin{array}{l}\text { Plasmodium } \\
\text { simium }\end{array}$ & Erythrocytes & & $\mathrm{X}$ & & & $\begin{array}{l}164,165,290 \\
291,317\end{array}$ \\
\hline $\begin{array}{l}\text { Plasmodium } \\
\text { pitheci }\end{array}$ & Erythrocytes & & & & $\mathrm{X}$ & $290,329,353$ \\
\hline $\begin{array}{l}\text { Plasmodium } \\
\text { malariae } \\
\text { syn }(P . \text { rodhaini })\end{array}$ & Erythrocytes & & & & $\mathrm{X}$ & $\begin{array}{l}68,69,290 \\
321,730,731\end{array}$ \\
\hline $\begin{array}{l}\text { Plasmodium } \\
\text { reichenowi }\end{array}$ & Erythrocytes & & & & $\mathrm{X}$ & $\begin{array}{l}65,66,71, \\
290,321,329, \\
714,801\end{array}$ \\
\hline $\begin{array}{l}\text { Plasmodium } \\
\text { schweitzi }\end{array}$ & Erythrocytes & & & & $\mathrm{X}$ & $\begin{array}{l}67,70,81, \\
290,732\end{array}$ \\
\hline $\begin{array}{l}\text { Plasmodium } \\
\text { hylobati }\end{array}$ & Erythrocytes & & & & $\mathrm{X}$ & $\begin{array}{l}71,141,290 \\
329,729\end{array}$ \\
\hline $\begin{array}{l}\text { Plasmodium } \\
\text { eylesi }\end{array}$ & Erythrocytes & & & & $\mathrm{X}$ & 290,882 \\
\hline $\begin{array}{l}\text { Plasmodium } \\
\text { jefferyi }\end{array}$ & Erythrocytes & & & & $\mathrm{X}$ & $290,883,884$ \\
\hline $\begin{array}{l}\text { Plasmodium } \\
\text { youngi }\end{array}$ & Erythrocytes & & & & $\mathrm{X}$ & 244,290 \\
\hline $\begin{array}{r}\text { Plasmodium } \\
\text { silvaticum }\end{array}$ & Erythrocytes & & & & $\mathrm{x}$ & 325,542 \\
\hline $\begin{array}{l}\text { Plasmodium } \\
\text { girardi }\end{array}$ & Erythrocytes & $\mathrm{X}$ & & & & $\begin{array}{l}84,290,319, \\
320\end{array}$ \\
\hline $\begin{array}{l}\text { Plasmodium } \\
\text { lemuris }\end{array}$ & Erythrocytes & $\mathrm{X}$ & & & & 290,404 \\
\hline $\begin{array}{l}\text { Plasmodium } \\
\text { foleyi }\end{array}$ & Erythrocytes & $X$ & & & & 319,320 \\
\hline $\begin{array}{l}\text { Hepatocystis } \\
\text { kochi } \\
\text { syn. (H. simiae) }\end{array}$ & Erythrocytes & & & $\mathrm{X}$ & & $\begin{array}{l}2,68,290, \\
313,314,323, \\
452,487,488, \\
518,524,578, \\
586,610,652, \\
674,823,867\end{array}$ \\
\hline $\begin{array}{l}\text { Hepatocystis } \\
\text { semnopitheci }\end{array}$ & Erythrocytes & & & $\mathrm{X}$ & & $\begin{array}{l}237,238,290 \\
465,681,714\end{array}$ \\
\hline $\begin{array}{l}\text { Hepatocystis } \\
\text { taiwanensis }\end{array}$ & Erythrocytes & & & $\mathrm{X}$ & & 70,290 \\
\hline $\begin{array}{l}\text { Hepatocystis } \\
\text { foleyi }\end{array}$ & Erythrocytes & $\mathrm{X}$ & & & & $70,84,290$ \\
\hline Hepatocystis sp. & Erythrocytes & & & & $\mathrm{X}$ & $\begin{array}{l}174,175,573, \\
594\end{array}$ \\
\hline $\begin{array}{l}\text { Sergentella } \\
\quad \text { anthropopitheci }\end{array}$ & Blood & & & & $\mathrm{X}$ & 173,290 \\
\hline
\end{tabular}


TABLE 45.3. (Continued).

\begin{tabular}{|c|c|c|c|c|c|c|}
\hline $\begin{array}{c}\text { Parasite } \\
\text { genus-species }\end{array}$ & $\begin{array}{l}\text { Location in } \\
\text { host }\end{array}$ & $\begin{array}{l}\text { Pro- } \\
\text { simians }\end{array}$ & $\begin{array}{l}\text { New World } \\
\text { monkeys }\end{array}$ & $\begin{array}{l}\text { Old World } \\
\text { monkeys }\end{array}$ & $\begin{array}{c}\text { Great } \\
\text { apes }\end{array}$ & References \\
\hline \multicolumn{7}{|l|}{ Toxoplasmasids } \\
\hline Sarcocystis kortei & $\begin{array}{l}\text { Striated muscle, } \\
\text { oral cavity, } \\
\text { heart, tongue, } \\
\text { esophagus }\end{array}$ & & & $\mathrm{x}$ & & $\begin{array}{l}23,192,290 \\
349,361,471 \\
555,638\end{array}$ \\
\hline $\begin{array}{c}\text { Sarcocystis } \\
\text { nesbitti }\end{array}$ & $\begin{array}{l}\text { Striated muscle, } \\
\text { oral cavity, } \\
\text { heart, tongue, } \\
\text { esophagus }\end{array}$ & & & $\mathrm{X}$ & & $23,290,555$ \\
\hline Sarcocystis sp. & $\begin{array}{l}\text { Striated muscle, } \\
\text { oral cavity, } \\
\text { heart, tongue, } \\
\text { esophagus }\end{array}$ & $\mathrm{X}$ & $\mathrm{X}$ & $\mathrm{X}$ & & $\begin{array}{l}26,168,290, \\
369,376,573 \text {, } \\
578,623,697 \text {, } \\
834,932\end{array}$ \\
\hline $\begin{array}{l}\text { Toxoplasma } \\
\text { gondii }\end{array}$ & $\begin{array}{l}\text { Brain, lungs, } \\
\text { liver, heart, } \\
\text { kidney, lymph- } \\
\text { nodes, blood, } \\
\text { other tissues }\end{array}$ & $\mathrm{X}$ & $\mathrm{X}$ & $\mathrm{X}$ & $\mathrm{X}$ & $\begin{array}{l}12,23,36, \\
37,81,82, \\
119,178,183, \\
290,381,418, \\
470,527,578, \\
579,581,628, \\
633,706,707, \\
708,709,726, \\
783,817,831, \\
842,858,913, \\
934,935\end{array}$ \\
\hline \multicolumn{7}{|c|}{ Neosporan parasites } \\
\hline $\begin{array}{l}\text { Encephalitozoon } \\
\text { cuniculi }\end{array}$ & $\begin{array}{l}\text { Brain, kidneys, } \\
\text { heart, lungs, } \\
\text { adrenals, other } \\
\text { tissues }\end{array}$ & & $\mathrm{X}$ & & & $15,79,656$ \\
\hline $\begin{array}{l}\text { Microsporidian } \\
\text { sp. }\end{array}$ & Intestine & & $\mathrm{X}$ & & & 781 \\
\hline $\begin{array}{l}\text { Haplosporids } \\
\text { Pneumocystis } \\
\quad \text { carinii }\end{array}$ & Lungs & & $\mathrm{x}$ & & $\mathrm{X}$ & $\begin{array}{l}117,543,679 \\
721,820\end{array}$ \\
\hline
\end{tabular}

A recent report documents severe intestinal disease in four juvenile macaques resulting from infection with Cryptosporidium sp. [906]. Two of the animals died naturally and the other two were humanely killed as a consequence of the illness, despite extensive therapy. Clinical signs in these young monkeys consisted of depression, dehydration, weight loss, and intractible diarrhea [906]. At necropsy, the animals were considered to be underweight for their age and dehydrated. The intestines were distended with gas and liquid. The mesenteric lymph nodes were enlarged in three of the four monkeys [906]. Histopathologically, the lesions in the small intestine consisted of blunting and fusion of villi, variation in height of the intestinal epithelium, necrosis of individual epithelial cells, and an increased mitotic index in the crypts. Variable numbers of organisms with both light microscopic and ultrastructural morphologic features consistent with Cryptosporidium sp. were seen adherent to enterocytes along the tips and side of villi, as well as within the crypts [906]. 
These cases indicate that cryptosporidial infection in young macaques can be a severe and potentially fatal disease. The cryptosporidia were associated with ultrastructural changes in the enterocytes that can result in malabsorption, as well as fluid loss in the infected host [906].

\section{MALARIA}

This disease, caused by parasites in the family Plasmodiidae, genus Plasmodium, affects both humans and animals [32, 71, 290, 742, 791, 874]. Malaria is one of the most important hemoprotozoal parasitic diseases of primates in the tropical and semitropical regions of the world. Spontaneous infection is universal among nonhuman primates with the exception of a few species: rhesus monkey, tamarins and marmosets (Callithrix sp. and Saguinus sp.), and owl monkeys. The malaria parasites that infect the anthropoid apes are a different group of Plasmodia than those that afflict monkey species. They are also homologous to the malaria parasites of humans, and they are considered to be indistinguishable morphologically. Cross-infection to humans has been documented. In the natural host, these organisms do not produce severe disease-there are no outward signs of disease seen and usually no fever. There may be a slight anemia associated with a lowgrade parasitemia in some animals, but they appear outwardly normal. In the aberrant host, infection with malarial parasites produces severe disease and debilitation that often leads to death.

Malaria parasites can be classified on the basis of the host infected-human, monkey, or anthropoid ape-or on the basis of the type of cyclic fever produced. Thus, quotidian malaria has a 24-hour cycle, tertian malaria cycles every 48 hours, and quartan malaria has a 72 -hour cycle. The periodicity of the cyclic fever is determined by the length of time the organisms parasitize the host erythrocytes.

The life cycle of malaria parasites has been reviewed in detail $[135,140,236$, $290,530,556,791,874]$. It is indirect with numerous mosquitoes in the genus Anopheles serving as biological vectors. Basically, the life cycle consists of two major phases: the sexual or sporogonic phase in the mosquito vector, and the asexual or shizogonic/gametogonic phase in the vertebrate host. The schizogonic phase is further divided into the exoerythrocytic or liver phase and the erythrocytic or blood phase.

The clinical signs reported in nonhuman primates infected with malaria consist of hepatosplenomegaly, fever, depression, listlessness, anorexia, and weight loss. Thrombocytopenia, leukopenia, progressive anemia, and reticulocytosis also have been reported. Diarrhea may be an accompanying symptom $[290,791,816$, 874]. Hematocrit, hemoglobin, mean corpuscular volume, and erythrocyte values are reported to be lower in infected nonhuman primates [186]. In general, young animals exhibit more severe symptoms than older animals [874]. Fever in infected nonhuman primates is less severe than in their human counterparts. The onset of fever coincides with the rupture of the parasitized erythrocytes and the release of toxic metabolic products into the bloodstream. Depending on the species of Plasmodium involved, this event can occur at 24-, 48-, or 72-hour intervals. Usually the natural host of a species of Plasmodia is asymptomatic.

Histopathology consists of functional and structural changes in the liver and pigment (hemazoin) deposition in the liver, spleen, and bone marrow. Hemor- 
rhages in the brain, splenic rupture, and lower nephron (tubular) necrosis of the kidney have been reported $[290,542,737,791,874]$.

The diagnosis of malaria depends on the demonstration and identification of the organisms in erythrocytes in thin or thick blood smears stained with Giemsa's or Wright-Giemsa stains [290,791].

Malaria in most nonhuman primates is generally not fatal. However, it may cause debilitation, and overt disease can be precipitated by stress, concurrent disease, splenectomy, or immunosuppression. Infected primates may also serve as sources of infection for humans provided the required mosquito vectors are present. All people actively working with or caring for nonhuman primates should be alert to the possible existence and potential liabilities of malarial infection.

\section{The Malaria of Old World Monkeys}

Plasmodium knowlesi. This is the only known quotidian (24-hour) malarial parasite. It is distributed geographically throughout Southeast Asia, and the natural hosts include the cynomolgus monkey, leaf monkey (Presbytes melalophus), and the pig-tailed macaque.

Plasmodium knowlesi produces a virulent infection in the rhesus monkey that is almost always fatal and resembles acute $P$. falciparum infection of humans $[70$, $80,126,236,243,290,318,466,502,542,773,797,874,925]$.

Plasmodium cynomolgi. This is a tertian malarial parasite with a geographic distribution including the East Indies, Southeast Asia, and the Philippine Islands. The natural hosts include a wide variety of Macaca species including the cynomolgus monkey, Toque monkey, pig-tailed macaque, bonnet macaque, Formosan rock macaque (Macaca cyclopis), and several species of leaf monkeys (Presbytes cristatus and $P$. entellus). Infection in the rhesus monkey with this organism is not as severe as with $P$. knowlesi and usually consists of low-grade parasitemia of long duration. This organism is similar to $P$. vivax of humans and is also transmissible to humans $[70,143,180,236,243,290,316,542,563,602$, $702,773,874]$.

Plasmodium gonderi. This tertian malarial parasite is distributed throughout west Africa and tropical central Africa and is the only simian Plasmodium found in Africa. Natural hosts include mangabeys (Cercocebus sp.) and drills (Mandrillus sp.). This parasite produces a high, chronic parasitemia in the rhesus monkey. Baboons (Papio sp.) and guenons (Cercopithecus sp.) are also susceptible. Humans have proven to be susceptible in experimental studies [68, 135, 290, $322,337,542,733,797,874]$.

Plasmodium fieldi. Plasmodium fieldi is a tertian malarial parasite found on the Malay Peninsula. Natural hosts include the Asian species of Macaca including the cynomolgus monkey and the pig-tailed macaque. Infection with $P$. fieldi produces a severe disease in the rhesus monkey that is often fatal. Humans seem to be resistant to infection with this organism [242, 290, 374, 542, 874, 881].

Plasmodium fragile. This is also a tertian malarial parasite with a geographic range throughout southern India and on the island of Sri Lanka. Natural hosts include the Toque monkey (Macaca sinica) and the bonnet macaque. Infection in 
the rhesus monkey produces severe disease that often kills the host $[135,180$, $290,542,703,874]$.

Plasmodium siminovale. This tertian malarial parasite is found on the island of Sri Lanka. The natural host is the Toque monkey. Even though the parasitemia is not particularly severe, a pronounced anemia has been reported as accompanying this infection. This parasite is considered to be similar to $P$. ovale of humans [181, $290,542,874]$.

Plasmodium coatneyi. This species of malarial parasite causes a mild tertian malaria in susceptible hosts. Its geographic distribution includes the Malay Peninsula and the Philippine Islands. The natural nonhuman primate host is the cynomolgus monkey. It is quite closely related morphologically to $P$. knowlesi, and the infection in the rhesus monkey is similar to $P$. knowlesi, producing a severe and often fatal disease accompanied by severe anemia [240, 241, 244, $263,290,542,874,881]$.

Plasmodium inui. Plasmodium inui is a mildly pathogenic species that produces a quartan malaria in susceptible hosts. It is very widespread throughout Southeast Asia and extends from India to the Philippine Islands. The natural hosts include the Asian species of Macaca, cynomolgus monkey, and pig-tailed macaque. It has also been reported from members of the genus Presbytis and the Celebes black ape (Cynopithecus niger). This infection is frequently encountered in Asian monkeys and can persist for at least several years even in animals removed from endemic areas. The parasite is considered to be homologous to $P$. malariae of humans, and humans are susceptible to infection with this organism $[70,71,236$, $237,290,353,399,502,542,773,795,796,874]$.

Plasmodium shorti. This quartan malarial parasite is found in India and on the island of Sri Lanka. Natural nonhuman primate hosts include the Toque monkey and the bonnet macaque. This organism has been transmitted experimentally to humans $[70,236,290,795]$.

\section{The Malarial Parasites of New World Monkeys}

Plasmodium simium. This is a tertian malarial parasite with a geographic distribution in the region of southern Brazil. The natural nonhuman primate hosts are howler monkey(Alouatta sp.) and woolly spider monkeys (Brachyteles arachnoides). The organism is similar to $P$. vivax of humans, and infection with this parasite has been reported in humans [135, 164, 290, 291, 317, 542, 874].

Plasmodium brazilianum. Plasmodium brazilianum is sometimes a markedly pathogenic species and is the commonest malarial parasite of New World monkeys. The natural nonhuman primate hosts include howler monkeys, spider monkeys (Ateles sp.), woolly spider monkeys, uakaris (Cacajao sp.), titis (Callicecus sp.), bearded sakis (Chiroptes sp.), capuchin monkeys (Cebus sp.), woolly monkeys (Langothrix sp.), and squirrel monkeys (Saimiri sp.) [2, 135, 211, 290, 337, $542,690,835,874]$. The geographic distribution ranges from Mexico throughout Central America and into South America down to Peru. Plasmodium brazilianum causes quartan malaria that can produce severe symptoms, and even adult monkeys have been known to die from this infection $[542,835]$. Usually it is seen as an infection at equilibrium having a low parasitemia that may persist for several years [874]. This organism is considered to be the same as $P$. malariae of 
humans, and humans are susceptible to experimental infection. This species may actually be $P$. malariae introduced into the New World by early explorers and modified through numerous passages in wild monkeys [206, 290].

\section{The Malaria of Anthropoid Apes}

Plasmodium pitheci. This is a tertian malarial parasite that was originally described in 1907 from Borneo in an orangutan (Pongo sp.) [353, 542]. Orangutans are the only nonhuman primates in which this parasite has been reported, and there are few details about the organism and the disease it produces. It has proved to be noninfectious for gibbons and monkeys in limited experimental studies.

Plasmodium rodhaini. Plasmodium rodhaini is found in west to central tropical Africa where it causes quartan malaria in its natural nonhuman primate hosts, chimpanzees (Pan sp.) and gorillas (Gorilla sp.). There is no morphological difference between this organism and Plasmodium malariae of humans, and these two parasites are considered to be synonymous. This is the only malarial parasite that occurs as a natural infection in humans and nonhuman primates to any great extent. Infection is easily transmitted from humans to chimpanzees and vice versa $[68,69,290,321,542,730,731,874]$.

Plasmodium reichenowi. This mildly pathogenic species occurs in west, central, and east tropical Africa. The natural nonhuman primate hosts include chimpanzees and gorillas. Plasmodium reichenowi causes a mild quartan malaria in these species. This organism is very similar to Plasmodium falciparum of humans. There is only a slight morphological difference between the two organisms, but attempts to transmit $P$. reichenowi to humans have been unsuccessful $[65,66,68$, $70,71,290,321,542,714,801,874]$.

Plasmodium schwetzi. Plasmodium schwetzi is a mildly pathogenic plasmodium species found in west Africa. The natural nonhuman primate hosts are chimpanzees and gorillas, and this parasite causes a mild tertian malaria in these species. The disease is often subclinical and not obvious unless the animal if splenectomized. Plasmodium schwetz $i$ is very similar to $P$. vivax of humans. This organism can infect humans and has been transmitted from chimpanzees to humans via mosquitoes. The disease in humans consists of a mild febrile period followed by a spontaneous cure $[67,70,71,81,290,542,732,874]$.

Plasmodium hylobati, Plasmodium eylesi, Plasmodium jefferyi, Plasmodium youngi. These four closely related parasites are found in the East Indies. They produce a quartan malaria in gibbons (Hylobates sp.), which are the natural nonhuman primate hosts for these parasites. Plasmodium hylobati, $P$. youngi, and $P$. eylesi are reported to be pathogenic. A febrile response associated with the parasitemia has been seen in gibbons infected with $P$. hylobati and $P$. youngi. Details of the clinical disease and pathology have not been reported [141, 244, $290,542,729,874,882-884]$.

\section{Hepatocystosis}

This disease is caused by parasites classified in the genus Hepatocystis in the family Haemoproteidae. The species reported to occur in nonhuman primates are listed in Table 45.3. 
Hepatocystis kochi was formerly classified in the family Plasmodiidae as Plasmodium kochi and currently has several other synonyms including $H$. joyeuxi, $H$. cercopitheci, $H$. bovilliezi, and $H$. simiae [290]. These sporozoan parasites are distributed in India to the East Indies subcontinent and throughout the African continent south of the Sahara Desert. Nonhuman primates reported to be affected with Hepatocystis sp. include Old World monkeys (African green monkeys, guenons, mangabeys, baboons, patas monkeys, colobus monkeys, Formosan rock macaques, other Macaca species, and leaf monkeys) and great apes (gibbons) [2, $174,175,290,313,323,487,542,557,794,867,874,884]$.

The incidence of Hepatocystis can exceed that of malaria [542] and has been reported from $42 \%$ to $56 \%$ in nonhuman primates obtained from west central Africa $[68,290,524]$ and from $40 \%$ to $75 \%$ in species from east central Africa [290, 586, 674, 823, 867].

The life cycle of Hepatocystis is indirect with midges (Culicoides sp.) serving as the biological vector $[290,323,542,791]$. Hepatocystis kochi is the only species in which the life cycle is completely known [313, 314, 530, 586]. The life cycle resembles that of Plasmodium sp. with the major exception that asexual schizogony does not take place in the host's erythrocytes. Schizogony in the liver produces grossly visible cysts called merocysts [290, 542, 874].

Hepatocystis infection in the nonhuman primate produces no cyclic fever or waves of parasites in the blood as occurs with malaria. Parasitemias are usually not too great, and evidently there is no adverse effect to the monkey's health.

Grossly, infected nonhuman primates have numerous, randomly scattered, grayish-white, translucent foci on the surface of the liver that correspond to the mature merocysts $[290,542,867]$. Histopathologically, there is no tissue reaction in the liver until the merocysts are formed. After the cyst develops, there is usually a neutrophilic exudate surrounding it. Following rupture of the cyst and release of the merozoites, a chronic granulomatous inflammatory reaction ensues with the infiltration of lymphocytes and macrophages. Healing results in fibrosis in and around the area where the cyst was located. These appear as white foci grossly [290, 542, 867].

Diagnosis is based on demonstration and identification of the parasite in thick blood smears or finding the typical hepatic lesions at necropsy and/or on histologic sections [290, 674, 867].

There are no public health considerations with this parasite since Hepatocystis sp. are not known to infect humans [290].

\section{TOXOPLASMOSIS}

The cause of this disease, Toxoplasma gondii, is a cosmopolitan protozoan parasite. Spontaneous infection with $T$. gondii has been reported in New World monkeys (squirrel monkeys, spider monkeys, sakis, owl monkeys, uakaris, marmosets, tamarins, woolly monkeys, titi monkeys, howler monkeys, woolly monkeys, and cebus monkeys), Old World monkeys (rhesus monkeys, stump-tail macaques, cynomolgus monkeys, and baboons), great apes (chimpanzees), and prosimians (Malayan tree shrew, ring-tailed lemur, ruffed lemur, and slow loris) $[12,23,36,37,81,119,178,183,290,381,418,470,527,579,581,628,633$, $706-709,726,783,817,831,842,858,913,934,935]$. New World monkeys are reported to be more susceptible to this disease $[23,381,429,581,742,791$, 
913]; marmosets are very susceptible and may die within 5-6 days after contacting the disease [37]. There is some question as to whether or not the infection reported in the baboon (Papio cynocephalus) and the chimpanzee was acquired naturally since both animals had been inoculated intracerebrally with material from guinea pigs and rabbits shortly before death [23, 742]. Also, there is some doubt about the validity of the diagnosis regarding two fatal cases of toxoplasmosis in lemurs (Lemur catta) from Japan [23]. The diagnosis was based on the microscopic demonstration of the parasites, and the published photomicrographs are reported not to be entirely convincing [23].

The morphology of $T$. gondii has been reviewed previously $[290,303,426$, 530]. Toxoplasma tachyzoites (formerly called trophozoites) are crescent- or banana-shaped structures that measure $4-8 \mu$ by $2-4 \mu$. One end is pointed, and the other is rounded and contains a centrally located nucleus. Tachyzoites can be found in various cells throughout the host and also in blood and peritoneal fluid. Initially, they occupy vacuoles in the host cells (current preferred terminology, group stage or colony) [303, 791]. As they multiply, a cyst forms around them. The encysted forms are known as bradyzoites (formerly called merozoites). The oocysts seen in the intestinal epithelial cells and feces of the cat measure $10 \times$ $12 \mu$ and are the smallest of the three common cat coccidia.

For an in-depth discussion of the life cycle of this interesting parasite, the reader is referred to the following references: $290,302,303,426$. Briefly, the life cycle consists of an enteroepithelial phase, which occurs only in the definitive host, and a extraintestinal or tissue phase, which occurs in all susceptible species (intermediate hosts). Asexual reproduction (endodyogony, endopolygony, and schizogony) and sexual reproduction (gametogony), which leads to the production of oocysts, occur in the intestinal epithelium of various domestic and feral members of the family Felidae. Unsporulated occysts are shed by these animals, the only known definitive hosts, and sporogeny occurs in the feces. In the extraintestinal cycle multiplication of tachyzoites occurs by endodyogony in all other tissues of the intermediate hosts, which include a wide variety of domestic and wild animals (including cats), birds, and some nonmammalian species [290, 302, 303, 791].

Infection with Toxoplasma can occur via transplacental transmission, consumption of tissue cysts, and consumption of oocysts. The organisms also can be spread mechanically and by insect vectors, such as cockroaches $[290,302,303$, 791, 879].

Nonspecific clinical signs reported in nonhuman primates infected with $T$. gondii include emesis, depression, diarrhea, anorexia, fever, cough, weakness, ocular and nasal discharges, pale mucous membranes, leukopenia, dyspnea, premature birth, abortion, and death [290, 429, 791]. Neurologic signs include circling, incoordination, paresis, and terminal convulsions [290, 429]. At necropsy, the most frequently observed abnormalities reported are cardiomegaly, myocardial necrosis, hemorrhagic lymphadenopathy, pulmonary edema, hepatic congestion, hepatocellular necrosis, splenomegaly, and splenic hyperplasia [36].

Histopathologically, focal hepatic necrosis, focal to diffuse necrotic lymphadenitis and splenitis, segmental intestinal lesions, interstitial and fibrinous pneumonia, and focal myocarditis have been reported. Necrotic foci and extracellular and/or intercellular tachyzoites are frequently found in conjunction with the 
inflammatory lesions. Lesions seen in the central nervous system include gliosis, focal hemorrhage, microscopic infarcts, and cellular degeneration [290, 429, 791]. Toxoplasma gondii cysts and free organisms have been noted in capillary endothelial cells and in the brain tissue, frequently with associated perivascular cuffing and cellular necrosis [429, 470, 581].

Diagnosis of toxoplasmosis depends on the demonstration and identification of the causative organism in smear preparations or in histopathologic sections, or by animal inoculation $[23,290,429,530]$. Laboratory tests include the indirect fluorescent antibody test, the Sabin-Feldman dye test, and the hemagglutination test. Isolation of $T$. gondii itself is most reliable but is time consuming and expensive. Recognition of oocysts in fecal samples of cats is important for the prevention and control of both animal and human toxoplasmosis [290, 429, 791]. The following references should be consulted for information about preparing fecal samples and the morphological differences between the common feline coccidia oocysts [189, 191].

Because toxoplasmosis can occur in humans, reasonable care should be taken to prevent infection in those personnel responsible for the care and use of nonhuman primates. Feces from Felidae should be removed frequently (within 24 hours) and preferably incinerated or disposed of in some other way that will prevent contact of vectors and fomites with sporulated oocysts [290].

\section{SARCOCYSTOSIS}

This disease is caused by coccidian parasites commonly classified in the genus Sarcocystis. The cystic phase of this parasite has been described in skeletal muscle fibers and occasionally in cardiac or smooth muscle fibers in a wide variety of animals throughout the world [23, 225, 290, 461, 530, 532]. These cysts are common in the skeletal muscle of the tongue or the esophageal muscle of many nonhuman primates. Sarcocystis kortei and $S$. nesbitti have been described in the rhesus monkey, and other unnamed species have been reported in both Old and New World monkeys [23, 192, 270, 290, 361, 376, 452, 471, 534, 550, 555, 623, $638,697,791,823]$.

It is now known that Sarcocystis has an obligatory two-host life cycle. The reader is referred to the definitive works published recently outlining the intricacies of the life cycle of this unique and interesting parasite [190, 302, 303, 743].

Lesions associated with spontaneous infections in nonhuman primates are rare [225, 290, 461, 791]. Inflammation characterized by infiltrates of lymphocytes, plasma cells, and eosinophils is associated with degeneration of the cysts within the muscle fibers. With time, there is a proliferation of fibrous connective tissue and resulting scar formation [791, 840]

\section{BABESIOSIS}

Two organisms are associated with this disease in nonhuman primates. Babesia pitheci has been reported from Old World monkeys (mangabeys, guenons, macaques, and baboons) $[23,290,315,385,386,449,738,837]$ and New World monkeys (marmosets) [385]. Its distribution and incidence in nature is unknown $[290,542]$. The complete life cycle is unknown, but ticks are thought to be the biological vectors $[23,290,542]$. This babesial parasite is considered to be only slightly pathogenic in normal intact monkeys but can result in severe anemia and 
death after splenectomy. Marked poikilocytosis and anisocytosis are associated with the anemia $[23,290,315,449,542,837]$. Babesia pitheci organisms are pyriform in shape and measure $2-6 \mu \mathrm{m}$ long. Round, elliptical, oval, lanceolate, and ameboid stages have been also observed in peripheral blood smears [23, $290,542]$.

The second babesia-like organism, Entopolypoides macaci, is a mildly pathogenic hemosporozoal parasite that has been described in Old World monkeys (cynomolgus monkeys, rhesus monkeys, baboons, and guenons) and great apes (chimpanzees) $[32,269,290,332,363,564,565,596,791]$. This organism does not have true pyriform stages, but early ring-shaped stages and ameboid stages with polypoid projections of cytoplasm similar to the true Babesia species have been seen. Entopolypoides macaci is smaller than Babesia and Plasmodium species parasites and is morphologically distinct [332, 542]. Parasitized erythrocytes are not enlarged, and pigment is not formed [542].

Fever, monocytosis, and anemia have been reported in parasitized nonhuman primates; however, infection with $E$. macaci appears to have little effect on the host $[290,542,565]$. Chronic, latent infections are known to occur, and splenectomy or immunosuppression will result in recurrence of the parasitemia and a marked increase in the intensity of hemolytic anemia and icterus. Under these conditions, the disease may be fatal [791]. There are indications that this organism is common in nonhuman primates [542].

Diagnosis of these two organisms depends on the demonstration and identification of the parasites within the host's erythrocytes [290, 791].

There is no public health significance associated with either $B$. pitheci or $E$. macaci infections because neither parasite has been reported in humans [290].

\section{ENCEPHALITOZOONOSIS}

The cause of this disease, Encephalitozoon cuniculi, is an obligate intracellular protozoan parasite that has been reported in a wide variety of vertebrate and invertebrate species [791]. Only a few cases have been reported in nonhuman primates, all in New World monkeys. Two of these cases involved squirrel monkeys, and one involved an unidentified microsporidian parasite in a dusky titi monkey (Callicebus moloch) [15, 79, 781].

Encephalitozoon cuniculi is a small, oval parasite that measures approximately $2.5 \times 1.5 \mu \mathrm{m}$. Division occurs by binary fission and produces two spores per sporont. The organisms can be distinguished from Toxoplasma and other parasites by their location, size, and positive staining characteristics with the gram stain and various silver impregnation methods. A coiled polar filament with four to five coils is a distinctive ultrastructural feature of $E$. cuniculi [791]. The life cycle of this parasite is not known completely at this time [791].

The signs described in nonhuman primates infected with $E$. cuniculi consist of nervous symptoms displayed by a 2-month-old squirrel monkey for approximately 1 month prior to death [79]. Lesions in this animal were focal granulomatous meningoencephalitis, hepatitis, and nephritis. Characteristic E. cuniculi organisms were seen by both light and electron microscopy. Also, a granulomatous encephalitis caused by $E$. cuniculi infection has been reported in a newborn squirrel monkey [15]. In the case involving the dusky titi, gram-positive, acidfast microsporidial organisms having a polar filament with as many as seven coils 
were found in the jejunal epithelium. It was felt that this organism was one that normally infects arthropods rather than $E$. cuniculi and that the monkey became infected through ingestion of the arthropods that it was able to capture in its outdoor environment. No host response to the presence of the organisms in the intestinal epithelium was reported [781]. Encephalitozoon cuniculi infection also has been reported as the cause of death in two infant squirrel monkeys [656].

Diagnosis of $E$. cuniculi can be made by finding the parasites associated with the typical lesions during histopathological examination of the tissues or by demonstration of the organisms in the urine. Currently, an immunofluorescence test that detects antibodies against the organisms and an intradermal test have both proved reliable $[429,791]$.

The public health importance of this organism is unknown at this time. There is one report of a natural $E$. cuniculi infection in a human; however, its validity has been questioned by some authors [791]. Nevertheless, personnel working or caring for nonhuman primates should follow accepted personal hygiene practices, and because urinary excretion has been proposed as a possible mode of transmission, excrement from nonhuman primates should be handled with caution. Also, care should be taken to ensure that captive nonhuman primates are protected from exposure to species known to be carriers of this organism [290].

\section{Ciliates}

The parasitic ciliates described from nonhuman primates are listed in Table 45.4. Balantidium coli is the only species that has been associated with lesions of the intestinal tract.

\section{BALANTIDIASIS}

The cause of this disease, Balantidium coli, has a world-wide distribution and has been reported in a number of nonhuman primate species including New World monkeys (howler monkeys, spider monkeys, and cebus monkeys), Old World

TABLE 45.4. Parasitic ciliates described from nonhuman primates.

\begin{tabular}{|c|c|c|c|c|c|c|}
\hline $\begin{array}{c}\text { Parasite } \\
\text { genus-species }\end{array}$ & $\begin{array}{l}\text { Location in } \\
\text { host }\end{array}$ & $\begin{array}{l}\text { Pro- } \\
\text { simians }\end{array}$ & $\begin{array}{l}\text { New World } \\
\text { monkeys }\end{array}$ & $\begin{array}{c}\text { Old World } \\
\text { monkeys }\end{array}$ & $\begin{array}{l}\text { Great } \\
\text { apes }\end{array}$ & References \\
\hline Balantidium coli & Cecum, colon & & $\mathrm{X}$ & $\mathrm{X}$ & $\mathrm{X}$ & $\begin{array}{l}38,90,290, \\
331,349,368, \\
459,461,485, \\
486,487,491, \\
494,529,599, \\
611,616,694, \\
712,791,839, \\
863,905,929\end{array}$ \\
\hline Balantidium sp. & Cecum, colon & & & $\mathrm{X}$ & & 573,578 \\
\hline $\begin{array}{l}\text { Troglodytella } \\
\text { abrassarti }\end{array}$ & Cecum, colon & & & & $\mathrm{X}$ & $\begin{array}{l}82,157,284, \\
290,463,491, \\
529,599,624, \\
863\end{array}$ \\
\hline $\begin{array}{l}\text { Troglodytella } \\
\text { gorillae }\end{array}$ & Cecum, colon & & & & $\mathrm{X}$ & 90,290 \\
\hline
\end{tabular}


monkeys (rhesus monkeys, cynomolgus monkeys, and baboons), and great apes (orangutans, chimpanzees, and gorillas) $[38,90,92,285,290,294,331,349$, 368-371, 437, 443, 459, 461, 487, 570, 599, 680, 687, 694, 723, 791, 839, 863, $905,929]$. The organism is usually nonpathogenic and is a common inhabitant of the cecum of nonhuman primates $[90,92,290,361,461,494,611,694,712$, 863]. Some have been reported to be symptomless carriers [137, 877].

Balantidium coli trophozoites are large, ovoid structures with a heavily ciliated outer surface $[18,89,290,351,473,530,790,791,899]$. This form measures $30-150 \times 25-120 \mu \mathrm{m}$. Internal structures consist of a macronucleus and micronucleus, two contractile vacuoles, and numerous food vacuoles. Cyst forms are spherical to ovoid and measure $40-60 \mu \mathrm{m}$ in diameter. Reproduction occurs by conjugation or by transverse binary fission. Infection occurs through ingestion of trophozoites or cysts $[90,290,530,791]$.

Infection with $B$. coli can cause severe ulcerative enterocolitis that can be fatal in great apes $[53,130,285,459,742]$. Signs of clinically ill animals are weight loss, anorexia, muscle weakness, lethargy, watery diarrhea, tenesmus, and rectal prolapse $[90,369,598,839]$. At necropsy, lesions may resemble those seen in amebiasis and may consist primarily of an ulcerative colitis [90, 461, 791]. Histologically, the ulcers may be large and may extend down to the muscularis mucosae $[290,791]$. There may be an accompanying lymphocytic infiltrate and, in time, coagulation necrosis and hemorrhage [290, 791]. Typical large $B$. coli organisms can be seen in masses associated with lesions in the tissues or in capillaries, lymphatics, or regional lymph nodes [90, 290, 791, 877].

Diagnosis depends on identification of the characteristic $B$. coli organisms associated with the typical colonic lesions [290, 461, 791]. Their presence as secondary invaders to a primary disease caused by other microorganisms should always be considered and must be ruled out [290].

Balantidium coli may cause diarrhea in humans; therefore, care should be taken in handling captive nonhuman primates to avoid infection [290].

\section{Metazoan Parasites}

\section{Nematodes}

The parasitic nematode genera described from nonhuman primates are listed in Table 45.5. Because nematodiasis is such a common occurrence in nonhuman primates, the majority of the genera listed will be discussed in detail.

\section{RHABDITOIDS}

\section{Strongyloidiasis}

This disease results from infection by the parasitic members of the genus Strongyloides. These small nematodes are prevalent in most tropical and subtropical areas, but their occurrence in the temperate zones is sporadic. Several species have been reported to affect nonhuman primates: Strongyloides cebus has been found in New World monkeys (cebus monkeys, woolly monkeys, spider monkeys, squirrel monkeys, and marmosets) $[207,290,437,461,492,541,634,650,752$, 791], Strongyloides fulleborni in Old World monkeys and great apes (rhesus monkeys, cynomolgus monkeys, guenons, baboons, and chimpanzees) $[290,345$, 
TABLE 45.5. Parasitic nematodes described from nonhuman primates.

\begin{tabular}{|c|c|c|c|c|c|c|}
\hline $\begin{array}{c}\text { Parasite } \\
\text { genus-species }\end{array}$ & $\begin{array}{l}\text { Location in } \\
\text { host }\end{array}$ & $\begin{array}{l}\text { Pro- } \\
\text { simians }\end{array}$ & $\begin{array}{l}\text { New World } \\
\text { monkeys }\end{array}$ & $\begin{array}{l}\text { Old World } \\
\text { monkeys }\end{array}$ & $\begin{array}{l}\text { Great } \\
\text { apes }\end{array}$ & References \\
\hline \multicolumn{7}{|l|}{ Strongyloidids } \\
\hline $\begin{array}{l}\text { Strongyloides } \\
\text { fulleborni }\end{array}$ & Intestines & & & $\mathrm{X}$ & $\mathrm{X}$ & $\begin{array}{l}3,284,290, \\
345,349,360, \\
650,741,742, \\
764,791,863, \\
878,921,922, \\
929\end{array}$ \\
\hline $\begin{array}{l}\text { Strongyloides } \\
\text { cebus }\end{array}$ & Intestines & & $\mathrm{X}$ & & & $\begin{array}{l}148,290,461 \\
541,650,791\end{array}$ \\
\hline $\begin{array}{l}\text { Strongyloides } \\
\text { stercoralis }\end{array}$ & Intestines & & & & $\mathrm{X}$ & $\begin{array}{l}176,290,531, \\
541,650,791 \text {, } \\
810,922\end{array}$ \\
\hline $\begin{array}{l}\text { Strongyloides } \\
\text { papillosus }\end{array}$ & Intestines & & & $\mathrm{X}$ & $\mathrm{X}$ & 290,541 \\
\hline Strongyloides sp. & & & $\mathrm{x}$ & $\mathrm{X}$ & $\mathbf{X}$ & $\begin{array}{l}448,570,578 \\
654,658,905 \text {, } \\
922\end{array}$ \\
\hline $\begin{array}{l}\text { Pelodera } \\
\quad \text { strongyloides }\end{array}$ & Skin lesions & & & $\mathrm{X}$ & & 530,742 \\
\hline \multicolumn{7}{|l|}{ Ancylostomatids } \\
\hline $\begin{array}{l}\text { Ancylostoma } \\
\text { duodenale }\end{array}$ & Sm. intestine & & & & $\mathrm{X}$ & $\begin{array}{l}38,116,290 \\
626,650,791 \\
929\end{array}$ \\
\hline $\begin{array}{l}\text { Necator } \\
\quad \text { americanus }\end{array}$ & Sm. intestine & & $\mathrm{X}$ & $\mathrm{X}$ & $\mathrm{X}$ & $\begin{array}{l}38,75,185, \\
280,290,486, \\
487,491,609, \\
650,723,742, \\
791,841,929\end{array}$ \\
\hline $\begin{array}{l}\text { Globocephalus } \\
\text { simiae }\end{array}$ & Sm. intestine & & & $\mathrm{x}$ & & 290,916 \\
\hline $\begin{array}{l}\text { Characostomum } \\
\text { asimilium }\end{array}$ & Sm. intestine & $\mathrm{X}$ & & $\mathrm{X}$ & & 290,919 \\
\hline Necator sp. & Sm. intestine & $\mathrm{X}$ & & & & 387 \\
\hline \multicolumn{7}{|l|}{ Strongylids } \\
\hline $\begin{array}{l}\text { Oesophagostomum } \\
\text { apiostomum }\end{array}$ & $\begin{array}{l}\text { Colon, } \\
\text { mesentery }\end{array}$ & & & $\mathrm{X}$ & & $\begin{array}{l}3,276,290, \\
349,350,530, \\
650,658,742, \\
791,921\end{array}$ \\
\hline $\begin{array}{l}\text { Oesophagostomum } \\
\text { bifurum }\end{array}$ & Colon & & & $\mathrm{X}$ & $\mathrm{X}$ & $\begin{array}{l}47,276,290, \\
339,345,485, \\
486,487,488, \\
493,494,530, \\
578,609,650, \\
742,791,863\end{array}$ \\
\hline $\begin{array}{l}\text { Oesophagostomum } \\
\text { aculeatum }\end{array}$ & Colon & & & $\mathrm{X}$ & & $\begin{array}{l}276,290,362, \\
530,650,712, \\
742,791,836\end{array}$ \\
\hline $\begin{array}{l}\text { Oesophagostomum } \\
\text { stephanostomum }\end{array}$ & Colon & & & $\mathrm{X}$ & $\mathrm{X}$ & $\begin{array}{l}276,280,290, \\
491,530,609, \\
650,712,742, \\
791,863\end{array}$ \\
\hline $\begin{array}{l}\text { Oesophagostomum } \\
\text { blanchardi }\end{array}$ & Colon & & & & $\mathrm{x}$ & $\begin{array}{l}290,650,791, \\
919\end{array}$ \\
\hline
\end{tabular}


TABLE 45.5. (Continued).

\begin{tabular}{|c|c|c|c|c|c|c|}
\hline $\begin{array}{c}\text { Parasite } \\
\text { genus-species }\end{array}$ & $\begin{array}{l}\text { Location in } \\
\text { host }\end{array}$ & $\begin{array}{l}\text { Pro- } \\
\text { simians }\end{array}$ & $\begin{array}{l}\text { New World } \\
\text { monkeys }\end{array}$ & $\begin{array}{l}\text { Old World } \\
\text { monkeys }\end{array}$ & $\begin{array}{l}\text { Great } \\
\text { apes }\end{array}$ & References \\
\hline $\begin{array}{l}\text { Oesophagostomum } \\
\text { sp. }\end{array}$ & $\overline{\text { Colon }}$ & & & $x$ & & $\begin{array}{l}1,335,488, \\
491,573,618, \\
654,658,660, \\
662,922\end{array}$ \\
\hline $\begin{array}{l}\text { Ternidens } \\
\text { deminutus }\end{array}$ & Cecum, colon & & & $\mathrm{X}$ & $\mathrm{X}$ & $\begin{array}{l}9,290,335, \\
339,349,530, \\
578,609,626, \\
650,712,742, \\
764,791,836\end{array}$ \\
\hline Ternidens sp. & Cecum, colon & & & $\mathrm{X}$ & & 494 \\
\hline \multicolumn{7}{|l|}{ Trichostrongylids } \\
\hline $\begin{array}{l}\text { Molineus } \\
\text { torulosus }\end{array}$ & Sm, intestine & & $\mathrm{X}$ & & & $\begin{array}{l}201,207,290, \\
461,509,791, \\
926\end{array}$ \\
\hline $\begin{array}{l}\text { Molineus } \\
\text { vexillarius }\end{array}$ & $\begin{array}{l}\text { Sm. intestine, } \\
\text { stomach }\end{array}$ & & $\mathrm{X}$ & & & $\begin{array}{l}148,168,201, \\
207,290,461, \\
689,791\end{array}$ \\
\hline Molineus elegans & Sm. intestine & & $\mathrm{X}$ & & & $\begin{array}{l}201,207,290, \\
461,791\end{array}$ \\
\hline $\begin{array}{l}\text { Molineus } \\
\quad \text { vogelianus }\end{array}$ & Sm. intestine & $\mathrm{X}$ & & & & 201,290 \\
\hline $\begin{array}{l}\text { Pithecostrongylus } \\
\text { alatus }\end{array}$ & Intestine & & & $\mathrm{X}$ & $\mathrm{X}$ & $\begin{array}{l}290,798,851, \\
919\end{array}$ \\
\hline \multicolumn{7}{|l|}{ Trichostrongylus } \\
\hline colubriformis & Sm. intestine & & & $\mathrm{X}$ & $\mathrm{X}$ & $\begin{array}{l}276,290,493 \\
509,530,578, \\
712,810,862\end{array}$ \\
\hline $\begin{array}{l}\text { Graphidioides } \\
\quad \text { berlai }\end{array}$ & Intestine & & $\mathrm{X}$ & & & $290,461,919$ \\
\hline $\begin{array}{c}\text { Nematodirus } \\
\text { weinbergi }\end{array}$ & Sm. intestine & & & & $\mathrm{X}$ & $290,699,919$ \\
\hline $\begin{array}{l}\text { Longistriata } \\
\quad \text { dubia }\end{array}$ & Sm. intestine & & $\mathbf{X}$ & & & $\begin{array}{l}148,207,290, \\
461,689\end{array}$ \\
\hline Nochtia nochi & Stomach & & & $\mathrm{X}$ & & $\begin{array}{l}1,58,290, \\
339,362,508, \\
650,742,784, \\
791,803,851, \\
922\end{array}$ \\
\hline $\begin{array}{l}\text { Tupaiostrongylus } \\
\text { liei }\end{array}$ & Sm, intestine & $\mathrm{X}$ & & & & 203,216 \\
\hline $\begin{array}{l}\text { Tupaiostrongylus } \\
\text { major }\end{array}$ & Sm. intestine & $\mathrm{X}$ & & & & 215 \\
\hline $\begin{array}{l}\text { Tupaiostrongylus } \\
\text { minor }\end{array}$ & Sm. intestine & $\mathrm{X}$ & & & & 215 \\
\hline $\begin{array}{l}\text { Anoplostrongylus } \\
\quad \text { liei }\end{array}$ & Intestine & $\mathrm{x}$ & & & & 216 \\
\hline $\begin{array}{l}\text { Hepatojarakus } \\
\text { malayae }\end{array}$ & Intestine & $\mathrm{X}$ & & & & 216 \\
\hline $\begin{array}{l}\text { Nycteridostrongy- } \\
\text { lus petersi }\end{array}$ & Intestine, lungs & $\mathrm{X}$ & & & & 216 \\
\hline $\begin{array}{l}\text { Trichostrongylus } \\
\text { sp. }\end{array}$ & Sm. intestine & & & $\mathrm{X}$ & & $\begin{array}{l}485,486,487, \\
491,494,616, \\
658\end{array}$ \\
\hline
\end{tabular}

(Continued) 
TABLE 45.5. (Continued).

\begin{tabular}{|c|c|c|c|c|c|c|}
\hline $\begin{array}{c}\text { Parasite } \\
\text { genus-species }\end{array}$ & $\begin{array}{l}\text { Location in } \\
\text { host }\end{array}$ & $\begin{array}{l}\text { Pro- } \\
\text { simians }\end{array}$ & $\begin{array}{c}\text { New World } \\
\text { monkeys }\end{array}$ & $\begin{array}{c}\text { Old World } \\
\text { monkeys }\end{array}$ & $\begin{array}{l}\text { Great } \\
\text { apes }\end{array}$ & References \\
\hline \multicolumn{7}{|l|}{ Metastrongylids } \\
\hline $\begin{array}{r}\text { Filaroides } \\
\text { barretoi }\end{array}$ & Lungs & & $\mathrm{X}$ & & & $\begin{array}{l}207,290,339 \\
584,742\end{array}$ \\
\hline $\begin{array}{c}\text { Filaroides } \\
\text { gordius }\end{array}$ & Lungs & & $\mathrm{X}$ & & & $\begin{array}{l}207,290,339 \\
742\end{array}$ \\
\hline Filaroides cebus & Lungs & & $\mathrm{X}$ & & & 63 \\
\hline Filaroides sp. & Lungs & & $\mathrm{X}$ & & & 148,290 \\
\hline Filariopsis arator & Lungs & & $\mathrm{X}$ & & & 290,919 \\
\hline Filariopsis asper & Lungs & & $\mathrm{X}$ & & & $207,461,865$ \\
\hline $\begin{array}{c}\text { Angiostrongylus } \\
\text { costaricensis }\end{array}$ & $\begin{array}{l}\text { Mesenteric } \\
\text { arteries }\end{array}$ & & $X$ & & & 802,846 \\
\hline $\begin{array}{c}\text { Angiostrongylus } \\
\text { malaysiensis }\end{array}$ & & $\mathrm{X}$ & & & & 535 \\
\hline \multicolumn{7}{|l|}{ Atractidids } \\
\hline $\begin{array}{l}\text { Probstmayria } \\
\quad \text { nainitalensis }\end{array}$ & Rectum & & & $\mathrm{X}$ & & 17 \\
\hline $\begin{array}{l}\text { Probstmayria } \\
\text { gombensis }\end{array}$ & Intestine & & & & $\mathrm{X}$ & 283,284 \\
\hline $\begin{array}{l}\text { Probstmayria } \\
\text { gorillae }\end{array}$ & Intestine & & & & $\mathrm{X}$ & 284,476 \\
\hline $\begin{array}{l}\text { Probstmayria } \\
\text { simiae }\end{array}$ & Intestine & & & & $\mathrm{X}$ & 284,558 \\
\hline \multicolumn{7}{|l|}{ Ascaridids } \\
\hline $\begin{array}{l}\text { Ascaris } \\
\quad \text { lumbricoides }\end{array}$ & Sm. intestine & & & $\mathrm{X}$ & $\mathrm{X}$ & $\begin{array}{l}209,290,509, \\
530,650,676, \\
712,723,742, \\
791,922\end{array}$ \\
\hline Ascaris sp. & Intestine & & & $\mathrm{X}$ & & 491 \\
\hline \multicolumn{7}{|l|}{ Subulurids } \\
\hline Subulura distans & $\begin{array}{l}\text { Stomach, } \\
\text { sm. intestine }\end{array}$ & $\mathrm{X}$ & & $\mathrm{X}$ & & $\begin{array}{l}290,346,609 \\
626,742,922\end{array}$ \\
\hline $\begin{array}{l}\text { Subulura } \\
\quad \text { malayensis }\end{array}$ & Colon & & & $\mathrm{X}$ & & 290,922 \\
\hline Subulura jacchi & Sm. intestine & & $\mathrm{X}$ & & & $\begin{array}{l}148,168,290 \\
554,689,742 \\
841,922\end{array}$ \\
\hline $\begin{array}{l}\text { Subulura } \\
\quad \text { perarmata }\end{array}$ & Cecum, colon & $\mathrm{X}$ & & & & 61 \\
\hline Subulura indica & $\begin{array}{l}\text { Lg. intestine, } \\
\text { cecum }\end{array}$ & $\mathrm{X}$ & & & & 477 \\
\hline \multicolumn{7}{|l|}{ Oxyurids } \\
\hline $\begin{array}{l}\text { Enterobius } \\
\quad \text { vermicularis }\end{array}$ & Lg. intestine & & & & $\mathrm{X}$ & $\begin{array}{l}96,131,290 \\
362,409,618 \\
650,718,723, \\
742\end{array}$ \\
\hline $\begin{array}{l}\text { Enterobius } \\
\quad \text { bipapillata }\end{array}$ & Lg. intestine & & & $\mathrm{X}$ & $\mathrm{X}$ & $\begin{array}{l}290,409,650 \\
723,919\end{array}$ \\
\hline $\begin{array}{l}\text { Enterobius } \\
\text { brevicauda }\end{array}$ & Lg. intestine & & & $\mathrm{X}$ & & $\begin{array}{l}290,409,485 \\
650,759,919\end{array}$ \\
\hline $\begin{array}{l}\text { Enterobius } \\
\quad \text { anthropopitheci }\end{array}$ & Lg. intestine & & & & $\mathrm{X}$ & $\begin{array}{l}209,328,409 \\
491,650,712 \\
723,742\end{array}$ \\
\hline $\begin{array}{c}\text { Enterobius } \\
\text { buckleyi }\end{array}$ & Lg. intestine & & & & $X$ & $\begin{array}{l}290,409,650 \\
759,919\end{array}$ \\
\hline
\end{tabular}


TABLE 45.5. (Continued).

\begin{tabular}{|c|c|c|c|c|c|c|}
\hline $\begin{array}{c}\text { Parasite } \\
\text { genus-species }\end{array}$ & $\begin{array}{l}\text { Location in } \\
\text { host }\end{array}$ & $\begin{array}{l}\text { Pro- } \\
\text { simians }\end{array}$ & $\begin{array}{c}\text { New World } \\
\text { monkeys }\end{array}$ & $\begin{array}{l}\text { Old World } \\
\text { monkeys }\end{array}$ & $\begin{array}{l}\text { Great } \\
\text { apes }\end{array}$ & References \\
\hline $\begin{array}{c}\text { Enterobius } \\
\quad \text { lerouxi }\end{array}$ & Lg. intestine & & & & $\bar{X}$ & $\begin{array}{l}290,409,650, \\
759,919\end{array}$ \\
\hline $\begin{array}{l}\text { Enterobius } \\
\text { pitheci }\end{array}$ & Lg. intestine & & & $\mathrm{X}$ & & 409 \\
\hline $\begin{array}{c}\text { Enterobius } \\
\text { parallela }\end{array}$ & Lg. intestine & & & $\mathrm{x}$ & & 409 \\
\hline $\begin{array}{l}\text { Enterobius } \\
\text { zakiri }\end{array}$ & Lg. intestine & & & $\mathrm{X}$ & & 409 \\
\hline $\begin{array}{c}\text { Enterobius } \\
\text { microon }\end{array}$ & Lg. intestine & & $\mathbf{X}$ & & & $290,650,919$ \\
\hline Enterobius sp. & Lg. intestine & $\mathrm{X}$ & & $\mathrm{X}$ & $\mathrm{X}$ & $\begin{array}{l}61,387,390, \\
448,485,658, \\
660,662,712, \\
922\end{array}$ \\
\hline $\begin{array}{l}\text { Buckleyenterobius } \\
\text { dentata }\end{array}$ & Lg. intestine & & & $\mathrm{x}$ & & 409 \\
\hline $\begin{array}{l}\text { Trypanoxyuris } \\
\text { trypanuris }\end{array}$ & Lg. intestine & & $\mathrm{X}$ & & & 409 \\
\hline $\begin{array}{l}\text { Trypanoxyuris } \\
\text { (Buckleyentero- } \\
\text { bius) atelis }\end{array}$ & Lg. intestine & & $\mathrm{x}$ & & & $\begin{array}{l}85,96,290 \\
409,759,919\end{array}$ \\
\hline $\begin{array}{l}\text { Trypanoxyuris } \\
\text { (Buckleyen- } \\
\text { terobius) } \\
\text { duplicidens }\end{array}$ & Lg. intestine & & $\mathrm{X}$ & & & $\begin{array}{l}85,409,290, \\
919\end{array}$ \\
\hline $\begin{array}{c}\text { Trypanoxyuris } \\
\text { (Buckleyen- } \\
\text { terobius) } \\
\text { lagothricis }\end{array}$ & Lg. intestine & & $\mathrm{X}$ & & & $\begin{array}{l}85,409,290 \\
919\end{array}$ \\
\hline $\begin{array}{c}\text { Trypanoxyuris } \\
\text { (Enterobius) } \\
\text { interlabiata }\end{array}$ & Lg. intestine & & $\mathrm{X}$ & & & $\begin{array}{l}290,409,650, \\
759,919\end{array}$ \\
\hline $\begin{array}{l}\text { Trypanoxyuris } \\
\text { minuta }\end{array}$ & Lg. intestine & & $\mathrm{X}$ & & & $\begin{array}{l}290,409,410, \\
461,650,683, \\
841,922\end{array}$ \\
\hline $\begin{array}{l}\text { Trypanoxyuris } \\
\text { sceleratus }\end{array}$ & Lg. intestine & & $\mathrm{X}$ & & & $\begin{array}{l}207,290,409 \\
412,461,650\end{array}$ \\
\hline $\begin{array}{r}\text { Trypanoxyuris } \\
\text { brachytelesi }\end{array}$ & Lg. intestine & & $\mathrm{X}$ & & & 409 \\
\hline $\begin{array}{l}\text { Trypanoxyuris } \\
\text { callithricis }\end{array}$ & Lg. intestine & & $\mathrm{x}$ & & & 409 \\
\hline $\begin{array}{l}\text { Trypanoxyuris } \\
\text { tamarini }\end{array}$ & Lg. intestine & & $\mathrm{X}$ & & & $\begin{array}{l}148,168,290 \\
410,412,450, \\
461,689\end{array}$ \\
\hline $\begin{array}{l}\text { Trypanoxyuris } \\
\text { oedipi }\end{array}$ & Lg. intestine & & $\mathrm{x}$ & & & 410 \\
\hline $\begin{array}{l}\text { Trypanoxyuris } \\
\text { goeldii }\end{array}$ & Lg. intestine & & $\mathrm{X}$ & & & 410 \\
\hline $\begin{array}{c}\text { Enterobius } \\
\text { lemuris }\end{array}$ & Lg. intestine & $\mathrm{X}$ & & & & 409 \\
\hline $\begin{array}{l}\text { Lemuricola } \\
\text { nycticebi }\end{array}$ & Lg. intestine & $\mathrm{x}$ & & & & 411 \\
\hline $\begin{array}{l}\text { Lemuricola } \\
\quad \text { malaysensis }\end{array}$ & Lg. intestine & $\mathrm{X}$ & & & & $28,208,411$ \\
\hline $\begin{array}{l}\text { Lemuricola } \\
\text { contagiosus }\end{array}$ & Lg. intestine & $\mathrm{X}$ & & & & $\begin{array}{l}411 \\
\quad \text { (Continued) }\end{array}$ \\
\hline
\end{tabular}


TABLE 45.5. (Continued).

\begin{tabular}{|c|c|c|c|c|c|c|}
\hline $\begin{array}{c}\text { Parasite } \\
\text { genus-species }\end{array}$ & $\begin{array}{l}\text { Location in } \\
\text { host }\end{array}$ & $\begin{array}{l}\text { Pro- } \\
\text { simians }\end{array}$ & $\begin{array}{l}\text { New World } \\
\text { monkeys }\end{array}$ & $\begin{array}{l}\text { Old World } \\
\text { monkeys }\end{array}$ & $\begin{array}{l}\text { Great } \\
\text { apes }\end{array}$ & References \\
\hline $\begin{array}{l}\text { Labatorobius } \\
\text { scleratus }\end{array}$ & Lg. intestine & & $\mathrm{X}$ & & & 290,919 \\
\hline $\begin{array}{l}\text { Oxyuronema } \\
\text { atelophorum }\end{array}$ & Lg. intestine & & $\mathrm{X}$ & & & $\begin{array}{l}290,339,474 \text {, } \\
919\end{array}$ \\
\hline $\begin{array}{l}\text { Primasubulura } \\
\text { jacchi }\end{array}$ & Lg. intestine & & $\mathrm{X}$ & & & 168 \\
\hline $\begin{array}{l}\text { Primasubulura } \\
\text { otolicini }\end{array}$ & Lg. intestine & $\mathrm{x}$ & & & & 232 \\
\hline Trypanoxyuris sp. & Lg. intestine & & $\mathrm{X}$ & & & 609,689 \\
\hline \multicolumn{7}{|l|}{ Spirurids } \\
\hline $\begin{array}{l}\text { Chitwoodspirura } \\
\text { serrata }\end{array}$ & $\begin{array}{l}\text { Stomach, } \\
\text { sm. intestine }\end{array}$ & & & & $\mathrm{X}$ & 290,919 \\
\hline $\begin{array}{l}\text { Spirura } \\
\text { guianensis }\end{array}$ & Esophagus & & $\mathrm{X}$ & & & $148,290,623$ \\
\hline $\begin{array}{c}\text { Trichospirura } \\
\text { leptostoma }\end{array}$ & Pancreas & & $\mathrm{x}$ & & & $\begin{array}{l}26,148,149, \\
290,461,492, \\
649,650,806, \\
807\end{array}$ \\
\hline $\begin{array}{l}\text { Protospirura } \\
\quad \text { (Mastophorus) } \\
\text { muricola }\end{array}$ & Stomach & & $\mathrm{x}$ & $\mathrm{X}$ & & $\begin{array}{l}101,290,292, \\
488\end{array}$ \\
\hline $\begin{array}{l}\text { Pterygodermatites } \\
\text { nycticebi }\end{array}$ & Sm. intestine & $\mathrm{X}$ & $\mathrm{X}$ & & & $536,593,856$ \\
\hline $\begin{array}{l}\text { Rictularia } \\
\text { alphi }\end{array}$ & Sm. intestine & & $\mathrm{X}$ & & & $\begin{array}{l}290,597,919, \\
922\end{array}$ \\
\hline Rictularia sp. & Sm. intestine & & $\mathrm{X}$ & & & $\begin{array}{l}4,591,592, \\
930\end{array}$ \\
\hline \multicolumn{7}{|l|}{ Thelaziids } \\
\hline $\begin{array}{l}\text { Streptopharagus } \\
\text { armatus }\end{array}$ & Stomach & & & $\mathrm{X}$ & $\mathrm{X}$ & $\begin{array}{l}290,349,578 \\
609,836\end{array}$ \\
\hline $\begin{array}{c}\text { Streptopharagus } \\
\text { pigmentatus }\end{array}$ & Stomach & & & $\mathrm{X}$ & $\mathrm{x}$ & $\begin{array}{l}290,339,362 \\
485,488,494, \\
609,712,764\end{array}$ \\
\hline $\begin{array}{l}\text { Streptopharagus } \\
\text { baylisi }\end{array}$ & Stomach & & & $\mathrm{X}$ & & $485,486,487$ \\
\hline $\begin{array}{l}\text { Streptopharagus } \\
\text { guptai }\end{array}$ & Rectum & & & $\mathrm{X}$ & & 809 \\
\hline $\begin{array}{l}\text { Streptopharagus } \\
\text { sp. }\end{array}$ & Stomach & & & $\mathrm{X}$ & & 485,616 \\
\hline $\begin{array}{l}\text { Gongylonema } \\
\text { macroguber- } \\
\text { naculum }\end{array}$ & $\begin{array}{l}\text { Esophagus, } \\
\text { stomach }\end{array}$ & & $\mathrm{X}$ & $\mathrm{X}$ & & $\begin{array}{l}290,339,461, \\
533,547,548 \\
609,650,791\end{array}$ \\
\hline $\begin{array}{l}\text { Gongylonema } \\
\text { pulchrum }\end{array}$ & $\begin{array}{l}\text { Tongue, oral } \\
\text { cavity, esopha- } \\
\text { gus, stomach }\end{array}$ & & $\mathrm{X}$ & $\mathrm{X}$ & & $\begin{array}{l}290,461,531, \\
547,548,650, \\
791\end{array}$ \\
\hline Physocephalus sp. & Stomach & & & $\mathrm{X}$ & & $654,421,911$ \\
\hline $\begin{array}{r}\text { Metathelazia } \\
\text { ascaroides }\end{array}$ & Lungs & & & $\mathrm{X}$ & & $\begin{array}{l}187,188,290 \\
919\end{array}$ \\
\hline $\begin{array}{l}\text { Thelazia } \\
\quad \text { callipaeda }\end{array}$ & Eyes & & & $\mathrm{x}$ & & $\begin{array}{l}271,290,531, \\
810\end{array}$ \\
\hline
\end{tabular}


TABLE 45.5. (Continued).

\begin{tabular}{|c|c|c|c|c|c|c|}
\hline $\begin{array}{c}\text { Parasite } \\
\text { genus-species }\end{array}$ & $\begin{array}{l}\text { Location in } \\
\text { host }\end{array}$ & $\begin{array}{l}\text { Pro- } \\
\text { simians }\end{array}$ & $\begin{array}{l}\text { New World } \\
\text { monkeys }\end{array}$ & $\begin{array}{l}\text { Old World } \\
\text { monkeys }\end{array}$ & $\begin{array}{l}\text { Great } \\
\text { apes }\end{array}$ & References \\
\hline \multicolumn{7}{|l|}{ Physalopterids } \\
\hline $\begin{array}{l}\text { Physaloptera } \\
\text { tumefaciens }\end{array}$ & Stomach & & & $\mathrm{X}$ & & $\begin{array}{l}290,362,494, \\
531,650,764, \\
836,907,921, \\
922\end{array}$ \\
\hline $\begin{array}{l}\text { Physaloptera } \\
\text { dilatata }\end{array}$ & Stomach & & $\mathrm{X}$ & & & $\begin{array}{l}168,290,650, \\
919\end{array}$ \\
\hline $\begin{array}{l}\text { Physaloptera } \\
\text { masoodi }\end{array}$ & Stomach & $\mathrm{X}$ & & & & 477 \\
\hline Physaloptera sp. & Stomach & $\mathrm{X}$ & & & & $\begin{array}{l}612,654,841, \\
911\end{array}$ \\
\hline $\begin{array}{l}\text { Abbreviata } \\
\quad \text { caucasica }\end{array}$ & Stomach & & & $\mathrm{X}$ & $\mathrm{X}$ & $\begin{array}{l}73,284,290, \\
419,485,487, \\
531,578,609 \\
626,742,919\end{array}$ \\
\hline $\begin{array}{l}\text { Abbreviata } \\
\text { poicilometra }\end{array}$ & Stomach & & & $\mathrm{X}$ & & $\begin{array}{l}290,756,799, \\
919\end{array}$ \\
\hline Abbreviata sp. & Stomach & & & $\mathrm{X}$ & & 616 \\
\hline \multicolumn{7}{|l|}{ Onchocercids } \\
\hline $\begin{array}{l}\text { Dirofilaria } \\
\text { magnilarvatum }\end{array}$ & $\begin{array}{l}\text { Subcutis, } \\
\text { peritoneal } \\
\text { membranes }\end{array}$ & & & $\mathrm{X}$ & & $\begin{array}{l}13,102,290 \\
500,580,605 \\
693,762,838 \\
901\end{array}$ \\
\hline $\begin{array}{l}\text { Dirofilaria } \\
\text { corynodes } \\
\text { syn. (D. aethiops, } \\
\text { D. schoutedeni) }\end{array}$ & Subcutis & & & $\mathrm{X}$ & & $\begin{array}{l}13,102,280, \\
290,364,507, \\
537,580,875, \\
885,886,887, \\
888\end{array}$ \\
\hline $\begin{array}{l}\text { Dirofilaria } \\
\text { immitis } \\
\text { syn. (D. pongoi) }\end{array}$ & $\begin{array}{l}\text { Subcutis, } \\
\text { muscle, right } \\
\text { ventricle }\end{array}$ & & & & $\mathrm{X}$ & $\begin{array}{l}13,102,290, \\
580,742,873, \\
885\end{array}$ \\
\hline $\begin{array}{l}\text { Dirofilaria repens } \\
\text { syn. (D. macacae) }\end{array}$ & Subcutis & & & $\mathrm{X}$ & & $605,754,885$ \\
\hline Dirofilaria sp. & Blood & & & $\mathrm{X}$ & & 561,777 \\
\hline $\begin{array}{r}\text { Edesonfilaria } \\
\text { malayensis }\end{array}$ & $\begin{array}{l}\text { Peritoneal } \\
\text { cavity }\end{array}$ & & & $\mathrm{X}$ & & $\begin{array}{l}290,308,531, \\
605,635,712, \\
920,924\end{array}$ \\
\hline Loa loa & $\begin{array}{l}\text { Subcutis, } \\
\text { mesenteries, } \\
\text { eyes }\end{array}$ & & $\mathrm{X}$ & $\mathrm{X}$ & & $\begin{array}{l}194,196,199, \\
280,290,514, \\
531,609,626, \\
646,734,755, \\
852,872,886\end{array}$ \\
\hline $\begin{array}{c}\text { Macacanema } \\
\text { formosana }\end{array}$ & $\begin{array}{l}\text { Peritracheal } \\
\text { connective } \\
\text { tissue }\end{array}$ & & & $\mathrm{X}$ & & $\begin{array}{l}43,290,531 \\
768\end{array}$ \\
\hline $\begin{array}{l}\text { Meningonema } \\
\text { peruzzii }\end{array}$ & $\begin{array}{l}\text { Subdural space- } \\
\text { medulla } \\
\text { oblongata }\end{array}$ & & & $\mathrm{X}$ & & 648 \\
\hline Brugia pahangi & $\begin{array}{l}\text { Lymphatic } \\
\text { system }\end{array}$ & $\mathrm{X}$ & & $\mathrm{x}$ & & $\begin{array}{l}13,102,221, \\
290,531,660, \\
662,766,767, \\
810\end{array}$ \\
\hline
\end{tabular}

(Continued) 
TABLE 45.5. (Continued).

\begin{tabular}{|c|c|c|c|c|c|c|}
\hline $\begin{array}{c}\text { Parasite } \\
\text { genus-species }\end{array}$ & $\begin{array}{l}\text { Location in } \\
\text { host }\end{array}$ & $\begin{array}{l}\text { Pro- } \\
\text { simians }\end{array}$ & $\begin{array}{l}\text { New World } \\
\text { monkeys }\end{array}$ & $\begin{array}{l}\text { Old World } \\
\text { monkeys }\end{array}$ & $\begin{array}{l}\text { Great } \\
\text { apes }\end{array}$ & References \\
\hline Brugia malayi & $\begin{array}{l}\text { Lymphatic } \\
\text { system }\end{array}$ & $\mathrm{X}$ & & $\mathrm{X}$ & & $\begin{array}{l}13,87,102, \\
280,290,507, \\
531,561,605, \\
660,662,810, \\
900\end{array}$ \\
\hline Brugia tupaiae & $\begin{array}{l}\text { Lymphatic } \\
\text { system }\end{array}$ & $\mathrm{X}$ & & & & 642 \\
\hline $\begin{array}{l}\text { Wuchereria } \\
\text { kalimantani }\end{array}$ & $\begin{array}{l}\text { Inguinal } \\
\text { lymphnodes, } \\
\text { testicles }\end{array}$ & & & $\mathrm{X}$ & & $\begin{array}{l}561,659,660 \\
662\end{array}$ \\
\hline $\begin{array}{l}\text { Filaria (?) } \\
\quad \text { nycticebus }\end{array}$ & Intestine & $\mathrm{X}$ & & & & 590,886 \\
\hline $\begin{array}{l}\text { Dipetalonema } \\
\text { gracile }\end{array}$ & Peritoneal cavity & & $\mathrm{X}$ & & & $\begin{array}{l}26,52,94, \\
148,167,168, \\
184,210,290, \\
310,475,508, \\
531,537,566, \\
568,569,580, \\
651,742,865, \\
885,889\end{array}$ \\
\hline $\begin{array}{c}\text { Dipetalonema } \\
\text { caudispina }\end{array}$ & Peritoneal cavity & & $\mathrm{X}$ & & & $\begin{array}{l}210,290,311, \\
580\end{array}$ \\
\hline $\begin{array}{l}\text { Dipetalonema } \\
\text { tenue }\end{array}$ & $\begin{array}{l}\text { Subcutis, body } \\
\text { cavity }\end{array}$ & & $\mathrm{X}$ & & & $\begin{array}{l}102,103,290 \\
919\end{array}$ \\
\hline $\begin{array}{l}\text { Dipetalonema } \\
\quad \text { barbascalensis }\end{array}$ & Peritoneal cavity & & $\mathrm{X}$ & & & 231 \\
\hline $\begin{array}{l}\text { Dipetalonema } \\
\text { petteri }\end{array}$ & $\begin{array}{l}\text { Pleura and } \\
\text { peritoneum }\end{array}$ & $\mathrm{X}$ & & & & 105 \\
\hline $\begin{array}{l}\text { Protofilaria } \\
\text { furcata }\end{array}$ & Thoracic cavity & $\mathrm{x}$ & & & & 114,886 \\
\hline $\begin{array}{l}\text { Parlitomosa } \\
\text { zakii }\end{array}$ & Peritoneal cavity & & $\mathrm{X}$ & & & $\begin{array}{l}210,231,461, \\
619,886\end{array}$ \\
\hline $\begin{array}{l}\text { Tetrapetalonema } \\
\text { (Dipetalonema) } \\
\text { obtusus }\end{array}$ & $\begin{array}{l}\text { Periesophagal } \\
\text { connective } \\
\text { tissue }\end{array}$ & & $\mathrm{X}$ & & & $\begin{array}{l}230,290,531 \\
580,923\end{array}$ \\
\hline $\begin{array}{l}\text { Tetrapetalonema } \\
\quad \text { (Depetalonemia) } \\
\text { marmosetae }\end{array}$ & $\begin{array}{l}\text { Subcutis, body } \\
\text { cavity }\end{array}$ & & $\mathrm{X}$ & & & $\begin{array}{l}210,273,290, \\
580,742,845, \\
885,923\end{array}$ \\
\hline $\begin{array}{l}\text { Tetrapetalonema } \\
\text { (Dipetalonema) } \\
\text { tamarinae }\end{array}$ & Peritoneal cavity & & $\mathrm{X}$ & & & $\begin{array}{l}167,210,230 \\
290\end{array}$ \\
\hline $\begin{array}{l}\text { Tetrapetalonema } \\
\text { (Dipetalonema) } \\
\text { atelensis }\end{array}$ & $\begin{array}{l}\text { Connective } \\
\text { tissue }\end{array}$ & & $\mathrm{X}$ & & & $\begin{array}{l}290,580,742 \\
885,919,923\end{array}$ \\
\hline $\begin{array}{l}\text { Tetrapetalonema } \\
\text { (Dipetalonema) } \\
\text { parvum }\end{array}$ & $\begin{array}{l}\text { Connective } \\
\text { tissue }\end{array}$ & & $\mathrm{X}$ & & & $\begin{array}{l}207,290,580, \\
742,885,922, \\
923\end{array}$ \\
\hline $\begin{array}{l}\text { Tetrapetalonema } \\
\text { (Depetalonema) } \\
\text { vanhoofi }\end{array}$ & $\begin{array}{l}\text { Connective } \\
\text { tissue }\end{array}$ & & $\mathrm{X}$ & & & 210,461 \\
\hline $\begin{array}{l}\text { Tetrapetalonema } \\
\quad \text { nicollei }\end{array}$ & $\begin{array}{l}\text { Peritoneal } \\
\text { cavity }\end{array}$ & & $\mathrm{X}$ & & & 210,885 \\
\hline $\begin{array}{l}\text { Tetrapetalonema } \\
\quad \text { dunni }\end{array}$ & Subcutis & $\mathrm{X}$ & & & & 603 \\
\hline $\begin{array}{l}\text { Dipetalonema } \\
\text { perstans }\end{array}$ & $\begin{array}{l}\text { Subcutis, body } \\
\text { cavity }\end{array}$ & & & & $\mathrm{x}$ & $\begin{array}{l}102,123,197, \\
276,290,340, \\
348,507\end{array}$ \\
\hline
\end{tabular}


TABLE 45.5. (Continued).

\begin{tabular}{|c|c|c|c|c|c|c|}
\hline $\begin{array}{c}\text { Parasite } \\
\text { genus-species }\end{array}$ & $\begin{array}{l}\text { Location in } \\
\text { host }\end{array}$ & $\begin{array}{l}\text { Pro- } \\
\text { simians }\end{array}$ & $\begin{array}{l}\text { New World } \\
\text { monkeys }\end{array}$ & $\begin{array}{l}\text { Old World } \\
\text { monkeys }\end{array}$ & $\begin{array}{l}\text { Great } \\
\text { apes }\end{array}$ & References \\
\hline $\begin{array}{c}\text { Dipetalonema } \\
\text { vanhoofi }\end{array}$ & $\begin{array}{l}\text { Peritoneal } \\
\text { cavity }\end{array}$ & & & $\mathrm{X}$ & $\mathrm{x}$ & $\begin{array}{l}42,100,101, \\
290,531,609, \\
646,669,670, \\
671,739,742, \\
885,923\end{array}$ \\
\hline $\begin{array}{l}\text { Dipetalonema } \\
\text { rodhaini }\end{array}$ & $\begin{array}{l}\text { Subcutis, body } \\
\text { cavity }\end{array}$ & & & & $\mathrm{X}$ & $\begin{array}{l}290,646,671, \\
742,885,919, \\
923\end{array}$ \\
\hline $\begin{array}{r}\text { Dipetalonema } \\
\text { streptocerca }\end{array}$ & $\begin{array}{l}\text { Subcutis, } \\
\text { peritoneal cavity }\end{array}$ & & & & $\mathrm{X}$ & $\begin{array}{l}122,195,197, \\
276,290,531, \\
646,671,742, \\
885,923\end{array}$ \\
\hline $\begin{array}{l}\text { Dipetalonema } \\
\text { digitatum }\end{array}$ & Peritoneal cavity & & & $\mathrm{X}$ & $\mathrm{X}$ & $\begin{array}{l}102,103,114, \\
290,605,742, \\
758,885,889 \\
919,923\end{array}$ \\
\hline $\begin{array}{l}\text { Dipetalonema } \\
\text { leopoldi }\end{array}$ & Subcutis & & & & $\mathrm{X}$ & 42 \\
\hline $\begin{array}{l}\text { Dipetalonema } \\
\text { gorillae }\end{array}$ & Subcutis & & & & $\mathrm{X}$ & 42 \\
\hline $\begin{array}{l}\text { Tetrapetalonema } \\
\text { papionis }\end{array}$ & $\begin{array}{l}\text { Skin and skeletal } \\
\text { muscle fascia }\end{array}$ & & & $\mathrm{X}$ & & 578 \\
\hline \multicolumn{7}{|l|}{ Dracunculids } \\
\hline $\begin{array}{l}\text { Dracunculus } \\
\text { medinensis }\end{array}$ & $\begin{array}{l}\text { Skin, subcutis, } \\
\text { viscera }\end{array}$ & & & $\mathrm{X}$ & & $\begin{array}{l}276,290,531 \\
609,742\end{array}$ \\
\hline $\begin{array}{c}\text { Onchocerca } \\
\text { volvulus }\end{array}$ & $\begin{array}{l}\text { Connective } \\
\text { tissue }\end{array}$ & & & & $\mathrm{X}$ & 42,646 \\
\hline \multicolumn{7}{|l|}{ Trichurids } \\
\hline $\begin{array}{l}\text { Trichuris } \\
\quad \text { trichiura }\end{array}$ & Cecum, colon & & $\mathrm{X}$ & $\mathrm{X}$ & $\mathrm{X}$ & $\begin{array}{l}3,75,76, \\
276,290,339, \\
350,461,486, \\
487,494,650, \\
654,688,712, \\
742,791,836, \\
921,922\end{array}$ \\
\hline Trichuris sp. & Cecum colon & $\mathrm{X}$ & & $\mathrm{X}$ & & $\begin{array}{l}61,387,390 \\
488,491,493 \\
494,616,658 \\
660,662,922\end{array}$ \\
\hline $\begin{array}{r}\text { Capillaria } \\
\text { hepatica }\end{array}$ & Liver & & $\mathrm{x}$ & $\mathrm{X}$ & $\mathrm{x}$ & $\begin{array}{l}276,290,349 \\
350,420,507 \\
531,742,810 \\
854,855\end{array}$ \\
\hline Capillaria sp. & Liver & & $\mathrm{X}$ & $\mathrm{x}$ & $\mathrm{X}$ & 922 \\
\hline \multicolumn{7}{|l|}{ Anatrichosomatids } \\
\hline $\begin{array}{l}\text { Anatrichosoma } \\
\text { cutaneum }\end{array}$ & $\begin{array}{l}\text { Nasal mucosa, } \\
\text { skin }\end{array}$ & & & $\mathrm{X}$ & & $\begin{array}{l}8,74,276, \\
290,650,712 \\
742,791,833\end{array}$ \\
\hline $\begin{array}{l}\text { Anatarichosoma } \\
\text { cynomolgi }\end{array}$ & Nasal mucosa & & & $\mathrm{X}$ & & $\begin{array}{l}8,129,290 \\
650,805\end{array}$ \\
\hline $\begin{array}{l}\text { Anatrichosoma } \\
\text { ocularis }\end{array}$ & Eye & $\mathrm{X}$ & & & & 282 \\
\hline
\end{tabular}


349, 634, 650, 654, 712, 741, 742, 752, 764, 791, 863, 922, 929], and Strongyloides stercoralis and Strongyloides sp. in Old World monkeys (patas monkeys) and great apes (gibbons, chimpanzees, gorillas, and orangutans) [38, 171, 177, $222,285,290,360,504,570,650,672,687,774,791,857,861,922]$. Only adult females and larvae are found in the gastrointestinal tract of the host animal. Migrating larvae can be found in the lungs and other parenchymatous organs. Parasitic males have never been described [290].

The life cycle of Strongyloides sp. is complex and consists of both parasitic and free-living generations $[116,290]$. The reader is referred to parasitology texts and referenced papers for a detailed discussion of this unique life cycle $[30,120$, $272,290,540,791,811]$. A variation in this life cycle, known as autoinfection, is a direct reinvasion of the host animal by filariform larvae that have developed during passage through the lower intestinal tract [171, 467]. This phenomenon results in hyperinfection of the infected host and is most responsible for sustained infections that result in clinical disease, severe damage to affected organs, and death $[77,95,171,290]$. There is also evidence of intrauterine or transcolostral transmission $[290,589,819]$. Fatal cases of strongyloidiasis have been reported in the chimpanzee, gibbon, orangutan, patas monkey, and woolly monkey [50, $51,171,176,228,360,422,504,526,571,636,650,677,857,861]$.

The disease in gibbons has been reported in detail [171]. Diarrhea, which may be hemorrhagic or mucoid, is the most common clinical sign described in infected animals [171]. Other common clinical signs are dermatitis, urticaria, anorexia, depression, listlessness, debilitation, vomiting, emaciation, reduced growth rate, dehydration, constipation, dyspnea, cough, prostration, and death $[171,274,290,461,742,791,810]$. Paralytic ileus is described in infected gibbons [171].

Gross lesions consist of catarrhal to hemorrhagic or necrotizing enterocolitis $[171,290,461,791]$. There may be a secondary peritonitis associated with the enterocolitis [290, 428]. Pulmonary hemorrhage is the most common lesion outside the digestive tract $[171,290,461,791]$. Histologic examination of the small intestine of the infected animal shows a multifocal erosive and ulcerative enteritis caused by adults, eggs, and rhabditiform larvae [171]. The mucosa contains numerous parasites, most of which are in intraepithelial tunnels or lumina of intestinal glands. These lesions may be infiltrated by neutrophils. Mononuclear cells and an occasional eosinophil can be seen in the lamina propria. Intestinal villi are short and blunt, and in severe infections bridging and loss of villi are seen [171]. In cases where autoinfection has occurred, changes in the small and large intestines in response to invasion by the filariform larvae range from a mild inflammatory cell response to severe, acute, or granulomatous or necrotizing enterocolitis. Larval invasion of the submucosal and serosal lymphatics results in a severe granulomatous endolymphangitis [171]. These changes are associated with various degrees of lymphatic obstruction and submucosal and serosal edema, fibrosis, or both. In the lungs, acute multifocal or diffuse hemorrhage is most common. Larval granulomas may be seen over the surface of the pleura. Filariform larvae also are seen in many tissues throughout the body, most commonly in the lymph nodes and liver [171]. Fatal strongyloidiasis has been described in lowland gorillas and chimpanzees [672].

This condition may be diagnosed by identification of typical larvae in the stool; by clinical signs; or by demonstration of parasitic adult females, eggs, and larvae at necropsy or at histologic examination [290]. 
Strongyloidiasis in nonhuman primate colonies is considered a potential public health problem. Infections by $S$. fulleborni that have been transmitted naturally from monkey to human have been reported [64, 290, 650, 742, 878]. Experimental infections in humans by Strongyloides sp. isolated from nonhuman primates also have been reported $[49,176,272,290,650,752]$.

\section{OXYURIDS}

\section{Oxyuriasis}

This disease is caused by infection by nematodes in the family Oxyuridae. Commonly known as pinworms, these small nematode parasites inhabit the colon and cecum of nonhuman primate hosts. Genera described in nonhuman primates are Trypanoxyuris and Oxyuronema species found in New World monkeys [207, 410, 412, 461]; Enterobius vermicularis and other Enterobius species, found in Old World monkeys and great apes; Enterobius anthropopitheci in the chimpanzee $[92,96,131,222,290,362,409,570,618,650,686,687,712,718,724$, $742,759,774,919,922]$; and several species in prosimian primates $[28,41$, 106-108]. These parasites are considered cosmopolitan in geographic distribution but are more prevalent in temperate and cold climates. The life cycle is direct.

Most reports of oxyuriasis in nonhuman primates state that these infections are essentially innocuous $[290,461,650,791]$. Clinical signs usually are limited to anal pruritis and irritation that may lead to self-mutilation, restlessness, and increased aggressiveness [131, 158, 200, 290, 461, 570, 650, 742, 774, 791]. Heavy pinworm infections are reported to be common in chimpanzees, and their coprophagic habits make constant reinfection inevitable [718]. Fatal cases of enterobiasis have been reported in chimpanzees [390, 439, 774, 775, 853], characterized by extensive ulcerative enterocolitis, peritonitis, and necrogranulomatous lymphadenitis involving the mesenteric lymphnodes. Numerous parasites with the morphologic characteristics of Enterobius vermicularis were associated with these lesions. There is also an early report of the death of a red spider monkey caused by an overwhelming pinworm infection [474].

Multiple intestinal polyps associated with immature male oxyurid parasites have been described in a male chimpanzee [848]. The gross and histologic characteristics of these lesions were identical to those produced by Nochtia nochti in the stomach and esophagus of Old World primates. It was thought that the lesion resulted from hypersensitivity to oxyurid infection in an aberrant host.

Adult oxyurids may be seen emerging from the anus. Perianal swabs or cellophane tape also can be used to recover the typical ellipsoid, asymmetrical pinworm eggs [276, 290].

Naturally infected nonhuman primates may be sources of infection in humans. Also, captive primates can acquire $E$. vermicularis infection from humans and then can act as reservoirs to reinfect them [290].

\section{STRONGYLIDS}

\section{Oesophagostomiasis}

This disease is caused by infection by nematodes in the genus Oesophagostomum. These parasites are known commonly as nodular worms and are considered to be the most common nematode parasite found in Old World monkeys and great apes 
$[42,290,442,570,645,650,712,742,791]$. They have been described in baboons, mangabeys, guenons, macaques, chimpanzees, and gorillas $[38,47,92$, $285,290,339,345,350,362,367,392,438,452,486,494,578,610,618,654$, $712,740,774,791,618,836,863,894]$. They are rare in New World monkeys $[207,650,922]$. Their geographic distribution is widespread, almost universal. At least 11 different species have been proposed but not clearly defined [645, 922]. The species mentioned most frequently are $O$. apiostomum, $O$. bifurcim, $O$. aculeatum, and $O$. stephanostomum $[276,290,531,742,764]$. The life cycle is direct.

Infected monkeys usually are asymptomatic, and light infections usually go unrecognized [290, 742, 791]. Monkeys with severe infections may show general unthriftiness and debilitation characterized by increased weight loss and diarrhea; the mortality rate increases for this group [290, 742, 791]. Lesions seen at necropsy consist of the typical oesophagostomum nodules, which are elevated, smooth $2-4 \mathrm{~mm}$ in diameter, and firm. They are seen most frequently on the serosal surface of the large intestine and cecum and in the mesentery supporting these organs $[92,290,618,645,742,791,869]$ but also in ectopic sites, such as the peritoneal wall, mesentery of the small intestine, omentum, kidney, liver, lungs, or diaphragm $[118,645,650,791]$. The nodules may be black or brown if there is associated hemorrhage; older nodules usually are white because of caseation of the contents. Viable worms may be seen in relatively young nodules; usually, however, the parasite is dead and surrounded by a mass of caseous debris. Older nodules may contain foci of mineralization [290, 350, 791]. The parasite and cell detritus usually are surrounded by a mantle of chronic inflammatory cells, mainly macrophages with scattered eosinophils and lymphocytes and plasma cells. Foreign-body giant cells sometimes are present in the cellular exudate. A fibrous capsule of various degrees of thickness and maturity, depending on the age of the nodule, surrounds the centrally located necroinflammatory mass [92, 290, 618, 791]. Sometimes ulcers form in the colonic mucosa at the point where the larval penetration occurred, and a migratory tract filled with inflammatory exudate connects the nodule in the wall with the intestinal lumen [290, 349, 350, 791]. Death of a chimpanzee from septicemia caused by bacterial invasion of esophagostomum nodules in the colon has been reported [ $892,893,894]$. Rupture of the nodules may result in acute or chronic peritonitis with fibrous peritoneal adhesions [645, 791]. Adhesions may restrict intestinal motility and result in obstruction or rarely in ascites $[290,742,791]$.

Oesophagostomum infection can be diagnosed by identifying the eggs in the feces. A problem arises, however, because the eggs of the different Oesophaostomum species cannot be differentiated from one another and also are indistinguishable from those of Ternidens and other hookworm species. The diagnosis of oesophagostomiasis based solely on typical eggs in the feces always should be questioned. Occasionally, adults are passed and can be identified. The postmortem diagnosis is based on typical nodular lesions or identification of adults, or both $[290,791]$.

This parasite has been reported to infect humans and therefore should be considered to have zoonotic potential $[290,347,546]$. Appropriate care in handling nonhuman primates should be exercised. 


\section{Ternideniasis}

The cause of this disease, Ternidens deminutus, is a strongyle that is related to the oesophagostomes and hookworms $[290,650]$. These parasites inhabit the cecum and colon and have been reported in Old World monkeys (macaques, guenons, and baboons) and the great apes (gorilla and chimpanzee) $[9,290,339,349,531$, $609,626,712,742,764,836,862,919]$. The morphologic features of the adult worms and their eggs are similar to those of Oesophagostomum [290, 742, 836]. The life cycle is direct and also is similar to Oesophagostomum [290]. There is little evidence of any lesions associated with this parasite; since it is a blood sucker, however, it can cause anemia and cystic nodules in the colonic wall [290, 531, 650].

This parasite can infect humans; it causes intestinal nodules. Infected captive animals should be handled with caution [290].

\section{ANCYLOSTOMATIDS}

\section{Ancylostomiasis and Necatoriasis}

The cause of these diseases, the hookworms usually found in humans, Ancylotoma duodenale and Necator americanus, are recorded occasionally in nonhuman primates, including monkeys, mandrills, baboons, gibbons, chimpanzees, and gorillas [38, 185, 222, 280, 290, 355, 358, 538, 570, 609, 647, 687, 718, 929]. Reports of their presence in South American monkeys are rare [650]. These parasites have a direct life cycle.

Clinical signs associated with heavy hookworm infection in nonhuman primates are similar to those produced by these parasites in humans and other animals and include anemia, eosinophilia, "pot-belly," dyspnea on exertion, and a general debilitation $[290,355,358,742]$. Necropsy findings have included a general pallor of all tissues. The mucosa of the small intestine was thickened by a chronic inflammatory reaction. Small hemorrhages were seen throughout the intestinal mucosa, and large numbers of hookworms were attached to the mucosa [358].

The diagnosis of hookworm disease is based on finding eggs in the feces or mature worms in the bowel at necropsy [290]. Since hookworm eggs are morphologically identical to those of several species of strongyles that also infect nonhuman primates, diagnosis based on the eggs alone should be viewed with caution [650].

Because humans are the normal definitive host for these parasites, infected captive primates should be handled with caution [290].

\section{TRICHOSTRONGYLIDS}

\section{Molineiasis}

This disease is caused by trichostrongyles in the genus Molineus. These are small, slender, pale red worms that inhabit the upper digestive tract, duodenum, and sometimes the pyloric region of the stomach of nonhuman primates. Occasionally, they may involve the pancreas and mesentery $[62,148,168,201,207$, $290,461,509,791,919]$. They are always found lying on the mucosa, never 
attached. Geographically, they are distributed throughout Central and South America, with one species occurring in Africa [201, 207, 290]. Species described in nonhuman primates include $M$. vexillarius in marmosets; $M$. elegans in squirrel monkeys, cebus monkeys, and howler monkeys; $M$. vogelianus in pottos; and $M$. torulosus in cebus monkeys, squirrel monkeys, and owl monkeys [148, 201, $207,290,461,791,926]$. Molineus torulosus is the only species reported to be a specific pathogen $[62,290,461,509,791]$.

The life cycle and method of transmission of these parasites are unknown. Diagnosis rests upon the identification of typical eggs in the feces or the presence of adult worms associated with typical lesions in the digestive tract [290, $531,649]$.

Infection with $M$. torulosus has been reported to cause hemorrhagic or ulcerative enteritis, sometimes associated with diverticula of the intestinal wall [62, $290,461,509,791]$. Serosal nodules that involved the upper portion of the small intestine have been seen in capuchin monkeys [62]. These nodules communicated with the intestinal lumen through $1-\mathrm{mm}$ reddish brown ulcers. Histologically, the nodules were composed of an intense granulomatous inflammatory response surrounded by a rim of proliferating fibrous connective tissue. The central portion contained a mass of nematode parasites and their eggs surrounded by eosinophilic debris. Neutrophils, histiocytes, and other chronic inflammatory cells were present adjacent to the worms. Chronic pancreatitis also was seen, with worms and eggs in inflamed pancreatic ducts $[62,791]$.

Nothing is known of the public health significance of this parasite [290].

\section{Nochtiasis}

This disease results from infection by trichostrongyles in the genus Nochtia. Nochtia nochti is a small, slender, bright red worm that has been described in the prepyloric region of the stomach of Asian macaques [58, 290, 508, 650, 746, $791,803,851]$. Eggs are thin shelled and ellipsoid, typical of members of the Trichostrongyles. Nochtia eggs can be differentiated from those of the superfamily Strongyloidea because they are larger and more pointed and are embryonated when passed in the feces. Free parasites are not found in the feces or the gastrointestinal tract. The life cycle is direct $[58,290]$.

At necropsy, hyperemic, cauliflowerlike masses are seen protruding from the gastric mucosa at the junction of the fundus and prepyloric regions. Histologically, these masses are benign inflammatory polyps composed of hyperplastic fronds of gastric mucosa and inflammatory tissue. Adult worms and their eggs can be found deep at the base of the lesion $[58,290,622,650,746,791$, $803,851]$.

Diagnosis depends on identification of typical eggs in the feces of affected animals or on the finding at necropsy of characteristic gastric polyps containing the parasite $[290,791]$.

Nothing is known of the public health aspects of this nematode.

\section{METASTRONGYLIDS}

\section{Angiostrongyliasis}

The cause of this disease, the metastrongyle Angiostrongylus costaricensis normally is found in rats in South and Central America [304]. It also causes a clinical syndrome in humans, particularly in children who reside in this geographic 
region. This syndrome is characterized by an inflammatory granulomatous mass that usually is located in the wall of the appendix but that can extend to the ileum, the cecum and ascending colon, and regional lymph nodes [304]. Histologically, the granulomatous mass is composed of chronic inflammatory cells and nematode eggs. Adult parasites reside in the arteries of the intestinal wall and mesentery [304].

Similar parasitic granulomas in the wall of the small intestine have been reported from two mustached marmosets (Saguinus mystax) [802, 846]. The histomorphologic features of these lesions were identical to those described previously for $A$. costaricensis infection in humans. In addition to the chronic inflammatory cells, the granulomas contained numerous nematode eggs and many larvae. The eggs of this particular parasite are reported to hatch within the rat or monkey host, then migrate to the gut and pass out in the feces to complete the life cycle [304]. Adult parasites with morphologic features consistent with a diagnosis of Angiostrongylus sp. were found in the mesenteric arteries associated with the granuloma.

On the basis of the nonhuman primate species involved, the fact that this species originated in the geographical region where this parasite has been reported to occur, the gross and histological appearance of the lesions, and the finding of adult Angiostrongylus sp. in the mesenteric arteries intimately involved with the granulomas, these parasites were identified as $A$. costaricensis. People who work with marmosets should be aware of the presence of this parasite and look for additional cases to document further its occurrence in South American monkeys.

\section{Pulmonary Nematodiasis}

This condition is the result of infection with the metastronglyid lungworms in the genera Filaroides and Filariopsis. These parasites are most commonly seen in New World monkeys (marmosets, squirrel monkeys, cebus monkeys, and howler monkeys) $[63,148,207,290,339,461,623,650,742,791,820,865,919]$.

In the live state, these parasites are very slender and fragile [650]. Adults are found in the terminal brochioles, respiratory bronchioles, and pulmonary aveoli $[290,461,650,791,820]$. The adult female is viviparious. They produce larvae that are coughed up, swallowed by the host, and passed in the feces. The remainder of the life cycle, and whether or not any intermediate hosts are required, is not known $[461,650,820]$.

Gross lesions in the pulmonary parenchyma are subtle. The lung appears normal except for the presence of varying numbers of randomly located, small, elevated, subpleural nodules, which may be hyperpigmented and cause the pleura to bulge. Histopathologically, there are varying degrees of atelectasis and foci of chronic inflammatory cells infiltrating the affected alveolar spaces and intraalveolar septae. Most infections are considered to be subclinical in nature, and although the parasite is common in certain species of New World monkeys, there is no evidence to suggest that the presence of lungworms has been the cause of death $[461,650,820]$.

Diagnosis can be made by finding and identifying the typical lungworm larvae in the feces in the intact animal. In the dead animal, the presence of characteristic gross and histopathologic pulmonary lesions associated with metastrongylid parasites is also diagnostic.

The public health significance of these parasites is unknown [290]. 


\section{ASCARIDIDS}

\section{Ascariasis}

This disease results from infection with members of the genus Ascaris, commonly known as roundworms. They are a common finding in the intestinal tract of nonhuman primates [650]. The specimens that have been recovered are reported to be indistinguishable from Ascaris lumbricoides in humans [19, 209, $844,922]$. Both Old World monkeys and great apes have been reported to be infected $[38,209,222,279,349,355,468,676,712,742,813,814,922]$. The life cycle of this parasite is direct.

Although roundworm infection in nonhuman primates is thought to be relatively innocuous and of little clinical significance $[570,650]$, fatal cases of ascariasis have been reported in both monkeys and great apes [349, 676, 813]. Death in the great apes was thought to be due to the presence of many worms, blockage of the bowel, and migration of the worms into the bile duct and liver.

Diagnosis of ascariasis is based on the presence of typical eggs in the feces or adults in the digestive tract at necropsy.

Since the ascarids reported in nonhuman primates are morphologically identical to $A$. lumbricoides in humans, cross-infection from infected animals to humans is possible. We could find no reports that documented such an occurrence; nevertheless, infected nonhuman primates should be considered a potential zoonotic threat and should be handled accordingly.

\section{SPIRURIDS}

\section{Trichospiruriasis}

The cause of this disease, Trichospirura leptostoma, is a spirurid nematode that parasitizes the pancreatic ducts of several species of New World monkeys including marmosets, squirrel monkeys, and owl monkeys. Geographic distribution is confined to Central and South America [148, 149, 290, 461, 649, 650, $806,807]$. Male and female adult parasites measure up to $15 \mathrm{~mm}$ and $120 \mathrm{~mm}$, respectively. The eggs are medium in size and are typically spirurid in that they are thick shelled and contain a larvae [534]. The complete life cycle is unknown [290, 461].

The parasite usually is found incidentally on histological examination. Infection usually causes little tissue destruction or inflammatory reaction. Tissue response apparently varies in proportion to the number of parasites present [461, $650]$. Chronic pancreatitis in association with the worms has been described in marmosets (Callithrix sp.) [650, 807]. Acute pancreatitis in owl monkeys consisting of a patchy granulocytic interstitial infiltrate adjacent to intralobular ducts was thought to be associated with leakage of retained pancreatic secretions. Larger ducts containing cross sections of worms also contained granulocytes $[649,650]$.

Nothing is known about the public health significance of this parasite.

\section{Pterygodermatitiasis}

The cause of this disease, Pterygodermatites nycticebi, is a spirurid nematode that has been reported from prosimians (slow loris), New World monkeys (tamarins and marmosets), and the great apes (gibbons) [536, 593, 856]. Several reports in members of the family Callitrichidae refer to this parasite by a synonym, Ric- 
tularia nycticebi $[4,591,592,930]$. The life cycle of $P$. nycticebi is indirect with cockroaches serving as intermediate hosts [593].

Morbidity and mortality associated with infection of $P$. nycticebi have been reported in golden lion tamarins (Leontopithecus rosalia) [593]. Clinical signs in heavily infected animals included extreme weakness, passage of watery diarrhea that contained the adult parasites, anemia, leukopenia, and hypoproteinemia [593]. At necropsy, masses of $P$. nycticebi parasites were found throughout the gastrointestinal tract. Histopathologically, the anterior ends of the adult worms were embedded in the mucosa of the small intestine. Larvae were seen deeper in the submucosa. In a few cases, worms were seen in the tunica muscularis and the pancreatic ducts. There was severe clubbing of the small intestinal villi and randomly located foci composed of a necrotic pseudomembrane containing spirurid eggs, numerous yeasts, and pseudohyphae consistent with Candida sp. [593].

Diagnosis depends upon demonstrating and identifying the characteristic spirurid eggs, adult worms, or larvae in the feces, in the gastrointestinal tract at necropsy, or in histopathological slide preparations.

Nothing is known about the public health significance of this parasite.

Methods of control should be directed against the cockroach intermediate host through reducing populations and preventing consumption by susceptible hosts.

\section{THELAZIIDS}

\section{Streptopharagiasis}

This disease is caused by parasitic members of the genus Streptopharagus. These are thelaziid nematodes that have been described in the stomach of Old World monkeys and great apes [290]. Streptopharagus armatus is reported in the rhesus monkey, other macaques, guenons, patas monkey, baboon, and gibbon [290, 349, 836]. Streptopharagus pigmentatus has been reported in the rhesus monkey, cynomolgus monkey, guenon, baboon, and gibbon [290, 339, 362, 712]. The life cycle of $S$. pigmentatus has been reviewed recently [551]. Little is known about the anatomic effects of these parasites [290]; however, there is one report of the death of a baby chimpanzee as a result of a perforated esophagus secondary to the migration of Streptopharagus sp. larvae [127].

\section{Gongylonemiasis}

The cause of this disease, parasites in the genus Gongylonema, are small filiform, thelaziid nematodes that have been reported in many nonhuman primates including both Old and New World monkeys [16, 290, 461, 533, 650, 911, 919, 922]. The species most commonly mentioned are G. macrogubernaculum and G. pulchrum. They have a cosmopolitan geographic distribution. A characteristic feature of the adults is several rows of conspicuous oval to round cuticular bosses located at the anterior extremity [650]. The life cycle is indirect, with cockroaches or dung beetles serving as intermediate hosts $[209,650]$.

Infection with this parasite is asymptomatic. Its presence usually is recognized only histologically and is considered to be an incidental finding. Adults are found in tunnels in the stratum malpighii of the squamous epithelium of the esophagus, lip, tongue, and other parts of the buccal cavity. They have been recovered from bronchi and the stomach. There is little or no tissue reaction [290, 461, 650].

Gongylonema pulchrum has been reported to occur in humans [290]. 


\section{PHYSALOPTERIDS}

\section{Physalopteriasis}

This disease is caused by infection by members of the genus Physaloptera. Four species of physalopterids have been reported to occur in the upper gastrointestinal tract of nonhuman primates [290]. Physaloptera tumefaciens is common in the stomach of Asian macaques [290, 362]. Physaloptera dilatata is found in the stomach of New World monkeys (titi monkeys, bearded sakis, and marmosets) $[168,207,290,492,919]$. Abbreviata caucasica has been found in the esophagus, stomach, and small intestine of the rhesus monkey, baboon, and orangutan [290, 419, 531, 626, 742, 919]. Abbreviata poicilometra has been found in the stomach of mangabeys and guenons [290, 756, 799, 919].

The life cycle of the physalopterids is indirect; an arthropod intermediate host is required. The entire life cycle is not completely understood, and a second intermediate or paratenic host may be necessary [290, 810]. Lesions result from the attachment of the worms to the wall of the affected organ. Gastritis, esophagitis, enteritis, erosion, and ulceration of the mucosa at the point of attachment are seen at necropsy [290]. Hyperplastic gastric lesions and perforation of the stomach wall associated with Physaloptera sp. infection in cynomolgus monkeys have been described $[287,746]$.

Diagnosis depends upon identification of the ova in the feces or the presence of adult worms attached to the mucosa of the upper digestive tract [290].

The public health aspects of these parasites are unknown.

\section{ONCHOCERIDS}

\section{Filariasis}

This condition is caused by a variety of onchocercid or filarial nematodes that are commonly encountered parasites of nonhuman primates. The adult filarids are long, slender worms that inhabit various tissue sites in the host animal outside the gastrointestinal tract $[290,461,531,650,742,791,889]$. The length of the adult worm varies, depending on the species, from a few centimeters to as much as 30 $\mathrm{cm}$. Female filariae are typically much larger than the males. The female worms produce small, primitive larvae called microfilariae that circulate throughout the peripheral blood or live in the skin of the definitive host $[167,168,290,461,650$, $742,889]$. The life cycle for these parasites is indirect. Obligatory intermediate hosts include an extensive variety of biting and blood- or lymph-sucking insects $[461,791]$. The filarial worms reported from nonhuman primates are listed in Table 45.5 .

Filariasis in New World Monkeys. At least 12 different species of filarid nematodes have been described from New World monkeys (marmosets, squirrel monkeys, cebus monkeys, spider monkeys, and owl monkeys). These include four species of Dipetalonema and seven species of Tetrapetalonema [52, 148, 168, $184,207,210,230,231,290,310,311,461,508,580,742,791,845,889$, 923]. Mixed infections in the same animal are reported to be very common, with some animals containing as many as four different species at the same time [461]. These species live in the abdominal or thoracic cavities or in the subcutaneous tissues of the definitive host. The worms that locate in the subcutaneous tissues 
cause very little if any inflammatory response $[461,650]$. Those species that are found in the serous cavities ( $D$. gracile and $D$. caudispina) can cause a fibrinopurulent peritonitis or pleuritis with associated fibrinous adhesions that frequently results in entrapment of the worms [461, 650].

The filarid Loa loa has been reported from a spider monkey [872].

Filariasis in Old World Monkeys. Dirofilaria corynodes is reported to be the most prevalent filarial parasite of African Old World monkeys (vervets, mangabeys, colobus monkeys, and patas monkeys). These are large parasites that are found in the subcutaneous tissues of the trunk and lower extremities where their presence causes very little tissue reaction [650]. Two closely related species, $D$. magnilarvatum and $D$. macacae, have been reported from Asian Old World monkeys (cynomolgus monkeys) [650].

Macacanema formosana has been reported from Asian Old World monkeys (Taiwan macaque and cynomolgus monkey). This parasite commonly inhabits the peritracheal connective tissue and the diaphragm of the infected host [43, $290,531,650,768]$.

Edesonfilaria malayensis has been described in Old World monkeys (cynomolgus monkeys and rhesus monkey) $[290,308,531,635,712,920,924]$. The adult worms usually are found free in the peritoneal cavity but have been reported from the subserosal connective tissue of the abdominal and thoracic cavities. In one report, they were associated with retroperitoneal masses composed of fibrous connective tissue and multiple foci of lymphoplasmocytic infiltrates. Numerous migratory tracts containing amorphous eosinophilic debris or adult $E$. malayensis worms were scattered throughout the masses [308]. In another report [635], six female adult Macaca fascicularis monkeys were found to be infected with $E$. malayensis. Clinical pathological findings in the infected animals included reduced values of hemoglobin and hematocrit, eosinophilia, elevated level of total protein, and a decreased $\mathrm{A} / \mathrm{G}$ ratio. Gross lesions consisted of thickening of the connective tissues, hemorrhage, and adhesions of the serosa in the site occupied by the worms. Mechanical damage was seen occasionally in tissues adjacent to the location of the parasites such as the pancreas and iliopsoas muscle. Splenic nodules were seen in five of the six infected monkeys. Histopathologically, there was hemorrhage, fibroplasia of connective tissue, and proliferation of granulation tissue with infiltration of eosinophils, lymphocytes, and other inflammatory cells associated with the presence of worms in the tissues. The nodular lesions in the spleen consisted of a highly vascular network of large reticuloendothelial cells, reticulum fibers, eosinophils, and erythrocytes. Microfilariae were present in some of these lesions, and it was felt that the splenic nodules were most likely associated with their existence in the spleen [635].

Lo a loa, normally a parasite of humans, has been reported from a variety of Old World monkeys (drills, baboons, mangabeys, and vervets) [199, 650, 755, 852]. Except for size, the worms described from both human and nonhuman primates are nearly identical morphologically. Another variation is the different circadian rhythm displayed by the microfilariae produced by the worms that infect nonhuman primates. These larvae circulate in the peripheral blood with a nocturnal periodicity [650]. Infection is usually asymptomatic, and significant lesions related to the presence of the adult $L$. loa in the subcutaneous tissues of nonhuman primate hosts has not been reported [650]. However, there has been a report 
of splenic lesions in drills infected with $L$. loa. Grossly, there were multiple nodules over the surface of the spleen resulting from the presence of granulomas that arose in the red pulp. Microscopically, the nodules were composed of fibrous connective tissue and numerous multinucleated giant cells, many of which contain disintegrating microfilariae within their cytoplasm. These lesions were attributed to the destruction of microfilariae within the spleen [198].

Brugia malayi and Brugia pahangi have been reported from a wide variety of Asian monkeys, particularly Macaca species [87, 500, 650]. Brugia malayi is also a parasite of humans. The adult parasites are found in the lymphatic and perilymphatic tissues of their nonhuman primate hosts. Symptoms and histopathology in the lymphatic system similar to that seen in human Malayan filariasis have not been reported in infected nonhuman primates [650]. Another species, Brugia tupaidae, has been described from the lymphatic system of prosimians (tree shrews) [650].

Meningonema peruzzii is a relatively recently reported filarid parasite from African Old World monkeys (vervets and talapoin monkeys) [648]. These worms were found only in the subarachnoid space along the dorsum of the brain stem at the level of the medulla oblongata. Female $M$. peruzzii, unlike most other filariae, are quadridelphic. Symptoms and lesions associated with infection by this parasite were not reported [648].

Filariasis in Great Apes. Onchocerca volvulus, a parasite of humans, has been reported from the gorilla $[42,650]$. The parasite was located in a subcutaneous fibrous nodule morphologically similar to that formed by the parasite in the human host $[42,650]$.

Dipetalonema streptocerca and $D$. rodhaini are two filarid parasites reported from the chimpanzee. These two parasites, along with $O$. volvulus from the gorilla, are different from other filarids in that the microfilariae produced by the female remain in the dermis rather than circulating in the peripheral blood $[646,650]$.

Several other filarids have been reported from the great apes including Dirofilaria pongoi from the heart of an orangutan [650, 873] and Dirofilaria immitis in the abdominal cavity of another orangutan $[650,760]$. Loa loa also has been reported from the chimpanzee and gorilla [42, 734]. Dipetalonema vanhoofi, a filarid parasite of the chimpanzee, inhabits the mesenteries and the connective tissue adjacent to the gall bladder, bile duct, liver, pancreas, and kidney; and the loose connective tissues and lymphatics surrounding the hepatic blood vessels $[650,671]$. They also have been described from the periadrenal connective tissue $[646,650]$.

Diagnosis is based on demonstration and identification of the adult worms in the body cavities or subcutaneous connective tissues, or the characteristic microfilariae in the blood [111, 290, 791].

Several filarial nematodes affect humans (Dirofilaria, Onchocerca, Loa), but the public health significance for the majority of these species is unknown $[276,290]$.

\section{TRICHURIDS}

\section{Trichuriasis}

This disease is caused by parasites in the genus Trichuris. Trichurid parasites are common inhabitants of the cecum and large intestine of nonhuman primates [276, 
$290,531,570,650,742]$. These nematodes have a world-wide distribution but are more prevalent in the tropics and subtropics [290]. Nonhuman primates reported to be affected include New World species (howler monkeys, woolly monkeys, and squirrel monkeys) [76, 208, 365, 492, 650, 814], Old World species (rhesus monkeys, cynomolgus monkeys, Japanese macaques, Formosan macaques, African green monkeys, and baboons) [75, 290, 339, 362, 487, 494, $609,712,741,764,836,922]$, and great apes (gibbons and chimpanzees) [222, $290,359,570,686,689,712,843,863,893]$. These parasites are morphologically identical to and indistinguishable from $T$. trichiura in humans [290, 570, $650,742]$. The life cycle is direct.

Trichuriasis in nonhuman primates usually does not cause any significant clinical problems [570]. Light infections are reported to cause no apparent lesions; heavy infections, however, have been reported to cause anorexia, a gray mucoid diarrhea, and sometimes death $[290,339,742,843]$. Fatal whipworm infections have been reported in two chimpanzees and a gibbon. Death of one chimpanzee was attributed to a severe parasitic enteritis; the second death was thought to be the result of a secondary bacterial infection resulting from the Trichuris infection $[843,893]$. The death of a gibbon with chronic colitis caused by an overwhelming infection with Trichuris and oxyurid parasites also has been reported [359].

Diagnosis depends upon the identification of the characteristic double operculated eggs in the feces or adults in the cecum [290].

Because the trichurid species that affects nonhuman primates is morphologically similar to the whipworm found in humans, cross-infection from animal to human is possible [290, 570, 742]. Appropriate care in the handling and management of infected captive nonhuman primates is recommended.

\section{Capillariasis}

This disease results from infection with the cosmopolitan trichurid parasite Capillaria hepatica. It has been reported in the liver of a wide variety of mammalian hosts throughout the world including New World monkeys (squirrel monkeys, cebus monkeys, and spider monkeys), Old World monkeys (rhesus monkeys), and great apes (chimpanzee) $[276,290,349,350,420,507,531,742$, $791,810,854,855]$.

The anterior portion of these parasites is more slender than the posterior, but it is not as pronounced as in the whipworms. The eggs have bipolar opercula, and the shell contains many small perforations giving it a striated appearance. This feature is unique and is used to distinguish ova of $C$. hepatica from those of other trichurids $[290,650,791]$.

The life cycle is direct and unique. Adult worms are found only in the hepatic parenchyma, and eggs are retained within the liver until the host dies or is killed. The eggs must be liberated from the liver either by decomposition of the original host or by passage through a predator or scavenger. Ingestion of infected liver tissue produces only spurious passage of the eggs in the feces. To become infective, the eggs must undergo embryonation under aerobic conditions. Infection occurs when embryonated eggs are ingested [290, 350, 650, 791].

The liver of infected animals reveals randomly placed white or yellow patches or nodules over the surface. Histopathologically, these foci are composed of adult C. hepatica and masses of eggs that are surrounded and infiltrated by proliferating fibrous connective tissue, chronic inflammatory cells, and foreign body giant 
cells. These lesions are ultimately converted to scar tissue, and the liver becomes cirrhotic. Fatal hepatitis has been reported in infected nonhuman primates [ 280 , $290,650,742,791]$.

Neither eggs or adult parasites will be found in the feces; therefore, diagnosis depends on demonstration and identification of the typical eggs and/or worms through liver biopsy or at necropsy [290, 791].

This parasite is pathogenic for humans, but because of the unusual life cycle of $C$. hepatica, infective nonhuman primates do not constitute a public health menace for persons caring for or working with them [276, 290].

\section{ANATRICHOSOMATIDS}

\section{Anatrichosomiasis}

This condition is the result of infection with the anatrichosomatid parasites Anatrichosoma cutaneum or Anatrichosoma cynomolgi. These two species have been described from both Asian and African Old World nonhuman primates (rhesus monkeys, cynomolgus monkeys, patas monkeys, vervets, talapoin monkeys, mangabeys, and baboons) $[8,129,142,276,290,446,585,644,712,742,805$, 833] and great apes (gibbons) [74].

The adult worms are small and slender. The eggs are large, barrel shaped, have bipolar opercula, and unlike Trichuris and Capillaria contain a larva [290, 650].

The entire life cycle and method of transmission are not known, but the cycle is thought probably to be direct. The female worms migrate through the stratified layers of squamous epithelium forming tunnels in which the embryonated eggs are deposited $[8,290,644,650]$. These tunnels are composed of epithelial cells and maintain their integrity. They are sloughed with the superficial keratin layers of the squamous epithelium and accumulate on the mucosal surface of the nares. Eggs are excreted from the host in the nasal secretions and less often in the feces $[8,290,644,650]$.

The original report of this parasite in nonhuman primates was from skin lesions on the extremities. Grossly, these lesions had the appearance of white, serpentine tracks on the palms and/or soles of the hands and feet $[650,833]$. Since then they have been reported only from the stratified squamous epithelium of the external nares. Infection of the nares does not produce serious disease and is usually subclinical but is considered to be common in susceptible animals. Histopathologically, the affected epithelium is diffusely hyperplastic and parakeratotic, and there is a mild inflammatory infiltrate composed of leukocytes and plasma cells in the underlying lamina propria [8, 290, 644, 650, 791].

Diagnosis in the living animal can be made through the use of nasal mucosal scrapings or swabs that will reveal the characteristic eggs. In the dead animal, finding of the parasite in microscopic slides of the mucosa is considered to be diagnostic [8, 290, 650, 791].

This parasite has been reported in humans, where it causes a type of creeping eruption. Even though infection in humans is considered to be uncommon, those personnel who work with and care for nonhuman primates should handle those species known to be infected or susceptible to infection with proper caution [276, $290,650]$.

A new species, Anatrichosoma ocularis, has been reported recently from the eye of a tree shrew (Tupaia glis) [282]. 


\section{Trematodes}

The parasitic trematodes described from nonhuman primates are listed in Table 45.6. The species most frequently mentioned in the literature are discussed below.

\section{TREMATODIASIS}

This disease in nonhuman primates can be caused by infection with a number of species of trematodes. Several of the more commonly encountered species will be discussed in detail.

\section{GASTRODISCOIDIASIS}

Gastrodiscoides hominis is a small, orange-red fluke that attaches to the mucosa of the cecum and colon $[290,339,380,791]$. The parasite is distributed throughout the tropical orient and has been described in various Macaca species that range throughout this geographic area $[276,290,339,362,380,403,570,695$, $712,764,791,903,940]$. The life cycle is indirect with a snail serving as the intermediate host $[276,290,791]$. Diagnosis can be made by identifying the characteristic eggs in the feces or by finding the typical adult flukes in the lumen of the cecum or colon at necropsy $[290,791]$.

Infection usually is asymptomatic when the parasites are present in small numbers. Heavy infections produce a mucoid diarrhea and mild chronic colitis. Attachment of the flukes to the intestinal mucosa results in focal lesions characterized by hyperemia, loss of surface epithelium, and necrosis. Neutrophilic infiltrates may be associated with these lesions. The submucosa may be sclerotic because of proliferation of fibrous connective tissue and a lymphoplasmacytic cell infiltrate $[276,290,296,380,403,791]$.

This parasite has been reported to cause a mild diarrhea in humans, but because of the obligatory snail intermediate host in the life cycle, infected captive monkeys are not a direct health hazard for humans [276, 290].

\section{WATSONIASIS}

Watsonius watsoni, W. deschieni, and W. macaci have been reported to inhabit the intestinal tract of several Old World primate species (guenons, baboons, and cynomolgus monkeys) $[276,280,290,339,362,609,742]$.

Adult trematodes of this genus are translucent, orange, and pear-shaped. The complete life cycle is not known but probably involves a snail intermediate host and is thought to be similar to that of Fasciola hepatica [276, 290, 742].

Watsonius watsoni and $W$. deschieni have been reported to be associated with diarrhea, severe enteritis, and death in monkeys [290, 339, 742]. Little else is known about the anatomic effects of these species [290].

Diagnosis can be made from the characteristic eggs in the feces or adults in the intestine at necropsy [290].

The public health considerations for these flukes are the same as described for G. hominis. 
TABLE 45.6. Parasitic trematodes described from nonhuman primates.

\begin{tabular}{|c|c|c|c|c|c|c|}
\hline $\begin{array}{c}\text { Parasite } \\
\text { genus-species }\end{array}$ & $\begin{array}{l}\text { Location in } \\
\text { host }\end{array}$ & $\begin{array}{l}\text { Pro- } \\
\text { simians }\end{array}$ & $\begin{array}{l}\text { New World } \\
\text { monkeys }\end{array}$ & $\begin{array}{l}\text { Old World } \\
\text { monkeys }\end{array}$ & $\begin{array}{l}\text { Great } \\
\text { apes }\end{array}$ & References \\
\hline \multicolumn{7}{|l|}{ Plagiorchids } \\
\hline $\begin{array}{l}\text { Plagiorchis } \\
\text { multiglan- } \\
\text { dularis }\end{array}$ & Intestine & & & $\mathrm{X}$ & & 482 \\
\hline \multicolumn{7}{|l|}{ Lecithodendriids } \\
\hline $\begin{array}{l}\text { Novetrema } \\
\text { nycticebi }\end{array}$ & Intestine & $\mathrm{X}$ & & & & 482 \\
\hline $\begin{array}{l}\text { Odeningotrema } \\
\text { apidion }\end{array}$ & Intestine & $\mathrm{X}$ & & & & 482 \\
\hline $\begin{array}{c}\text { Odeningotrema } \\
\text { bivesicularis }\end{array}$ & Intestine & $\mathrm{X}$ & & & & 482 \\
\hline $\begin{array}{l}\text { Phaneropsolus } \\
\text { bonnei }\end{array}$ & Intestine & $\mathrm{x}$ & & $\mathrm{X}$ & & 482 \\
\hline $\begin{array}{c}\text { Phaneropsolus } \\
\text { lakdivensis }\end{array}$ & Intestine & $\mathrm{X}$ & & & & 147,482 \\
\hline $\begin{array}{l}\text { Phaneropsolus } \\
\text { longipenis }\end{array}$ & Intestine & $\mathrm{X}$ & & & $\mathrm{X}$ & 147,482 \\
\hline $\begin{array}{c}\text { Phaneropsolus } \\
\text { orbicularis }\end{array}$ & Intestine & & $\mathrm{x}$ & & & $\begin{array}{l}147,148,290, \\
461,482,689, \\
841,917\end{array}$ \\
\hline $\begin{array}{l}\text { Phaneropsolus } \\
\text { oviformis }\end{array}$ & Intestine & $\mathrm{X}$ & & $\mathrm{X}$ & & $147,290,482$ \\
\hline $\begin{array}{l}\text { Phaneropsolus } \\
\text { simiae }\end{array}$ & Intestine & & & $\mathrm{X}$ & & 482 \\
\hline $\begin{array}{l}\text { Phaneropsolus } \\
\text { aspinosus }\end{array}$ & Intestine & & & $\mathrm{X}$ & & 657 \\
\hline $\begin{array}{c}\text { Primatotrema } \\
\text { macacae }\end{array}$ & Intestine & & & $\mathrm{x}$ & & $147,290,482$ \\
\hline \multicolumn{7}{|l|}{ Dicrocoeliids } \\
\hline Athesmia foxi & Bile ducts & & $\mathrm{X}$ & & & $\begin{array}{l}26,59,147, \\
235,275,280, \\
290,311,333, \\
461,482,689, \\
742\end{array}$ \\
\hline $\begin{array}{l}\text { Athesmia } \\
\quad \text { heterolecithodes }\end{array}$ & Bile ducts & & $\mathrm{X}$ & & & 482 \\
\hline $\begin{array}{l}\text { Brodenia } \\
\quad \text { laciniata }\end{array}$ & $\begin{array}{l}\text { Bile ducts, } \\
\text { pancreas }\end{array}$ & & & $\mathrm{X}$ & & $\begin{array}{l}147,290,482 \\
486,487\end{array}$ \\
\hline Brodenia serrata & Pancreas & & & $\mathrm{X}$ & & $147,290,482$ \\
\hline $\begin{array}{l}\text { Concinnum } \\
\text { brumpti syn. } \\
\text { (Eurytrema } \\
\text { brumpti) }\end{array}$ & $\begin{array}{l}\text { Bile duct, } \\
\text { pancreas }\end{array}$ & & & & $\mathrm{X}$ & $\begin{array}{l}147,280,290 \\
482,694,701, \\
791,828,922\end{array}$ \\
\hline $\begin{array}{l}\text { Controrchis } \\
\text { biliophilus }\end{array}$ & $\begin{array}{l}\text { Gall bladder, } \\
\text { bile ducts }\end{array}$ & & $\mathrm{X}$ & & & $147,461,482$ \\
\hline $\begin{array}{l}\text { Dicrocoelium } \\
\text { colobusicola }\end{array}$ & Bile ducts & & & $\mathrm{X}$ & & 147,482 \\
\hline $\begin{array}{c}\text { Dicrocoelium } \\
\text { lanceatum }\end{array}$ & Bile ducts & & & $\mathrm{X}$ & $\mathrm{X}$ & $\begin{array}{l}147,367,482, \\
922\end{array}$ \\
\hline $\begin{array}{l}\text { Dicrocoelium } \\
\text { macaci }\end{array}$ & Bile ducts & & & $\mathrm{X}$ & $\mathrm{X}$ & $\begin{array}{l}147,280,290, \\
356\end{array}$ \\
\hline $\begin{array}{l}\text { Euparadistomum } \\
\text { cercopitheci }\end{array}$ & Gall bladder & & & $\mathrm{X}$ & & 482 \\
\hline
\end{tabular}


TABLE 45.6. (Continued).

\begin{tabular}{|c|c|c|c|c|c|c|}
\hline $\begin{array}{c}\text { Parasite } \\
\text { genus-species }\end{array}$ & $\begin{array}{l}\text { Location in } \\
\text { host }\end{array}$ & $\begin{array}{l}\text { Pro- } \\
\text { simians }\end{array}$ & $\begin{array}{l}\text { New World } \\
\text { monkeys }\end{array}$ & $\begin{array}{l}\text { Old World } \\
\text { monkeys }\end{array}$ & $\begin{array}{l}\text { Great } \\
\text { apes }\end{array}$ & References \\
\hline $\begin{array}{l}\text { Eurytrema } \\
\text { pancreaticum }\end{array}$ & Pancreatic ducts & & & $\mathrm{X}$ & & 482 \\
\hline Eurytrema satoi & $\begin{array}{l}\text { Bile ducts, } \\
\text { pancreas }\end{array}$ & & & $\mathrm{X}$ & $\mathrm{X}$ & $\begin{array}{l}147,280,290, \\
482\end{array}$ \\
\hline $\begin{array}{l}\text { Leipertrema } \\
\text { rewelli }\end{array}$ & Pancreas & & & & $\mathrm{X}$ & $\begin{array}{l}147,290,482, \\
760\end{array}$ \\
\hline $\begin{array}{r}\text { Platynosomum } \\
\text { amazonensis }\end{array}$ & $\begin{array}{l}\text { Gall bladder, } \\
\text { bile ducts }\end{array}$ & & $\mathrm{X}$ & & & $\begin{array}{l}147,148,290, \\
461,482\end{array}$ \\
\hline $\begin{array}{l}\text { Platynosomum } \\
\text { marmoseti }\end{array}$ & $\begin{array}{l}\text { Gall bladder, } \\
\text { bile ducts }\end{array}$ & & $\mathrm{X}$ & & & $\begin{array}{l}147,148,290, \\
461,482\end{array}$ \\
\hline $\begin{array}{l}\text { Zonorchis } \\
\text { goliath }\end{array}$ & Bile ducts & & $\mathrm{X}$ & & & 461,482 \\
\hline $\begin{array}{l}\text { Zonorchis } \\
\quad \text { microcebi }\end{array}$ & Bile ducts & & $\mathrm{X}$ & & & 482 \\
\hline \multicolumn{7}{|l|}{ Fasciolids } \\
\hline $\begin{array}{l}\text { Fasciola } \\
\quad \text { hepatica }\end{array}$ & Liver & & & $\mathrm{X}$ & & $\begin{array}{l}147,290,339 \\
362,482\end{array}$ \\
\hline Fasciolopsis buski & $\begin{array}{l}\text { Duodenum, } \\
\text { stomach }\end{array}$ & & & $\mathrm{X}$ & & $\begin{array}{l}147,276,290, \\
361,482\end{array}$ \\
\hline \multicolumn{7}{|l|}{ Opisthorchids } \\
\hline $\begin{array}{l}\text { Chonorchis } \\
\text { sinensis }\end{array}$ & Bile ducts & & & $\mathrm{X}$ & & 482,490 \\
\hline $\begin{array}{l}\text { Opisthorchis } \\
\text { felineus }\end{array}$ & $\begin{array}{l}\text { Bile and } \\
\text { pancreatic ducts }\end{array}$ & & & $\mathrm{X}$ & & 482 \\
\hline \multicolumn{7}{|l|}{ Heterophyids } \\
\hline $\begin{array}{l}\text { Haplorchis } \\
\text { pumilio }\end{array}$ & Intestine & & & $\mathrm{X}$ & & 482 \\
\hline $\begin{array}{l}\text { Haplorchis } \\
\quad \text { yokogawai }\end{array}$ & Intestine & & & $\mathrm{X}$ & & 147,482 \\
\hline $\begin{array}{c}\text { Metagonimus } \\
\text { yokogawai }\end{array}$ & Intestine & & & $\mathrm{X}$ & & 147,482 \\
\hline $\begin{array}{l}\text { Pygidiopsis } \\
\text { summa }\end{array}$ & Intestine & & & $\mathrm{X}$ & & 482 \\
\hline \multicolumn{7}{|l|}{ Microphallidids } \\
\hline $\begin{array}{l}\text { Spelotrema } \\
\quad \text { brevicaeca }\end{array}$ & Intestine & & & $\mathrm{X}$ & & 482 \\
\hline \multicolumn{7}{|l|}{ Echinostomatids } \\
\hline $\begin{array}{l}\text { Artyfechinostomum } \\
\text { sp. }\end{array}$ & Intestine & & & $\mathrm{X}$ & & $147,290,482$ \\
\hline $\begin{array}{l}\text { Echinostoma } \\
\text { aphylactum }\end{array}$ & Sm. intestine & & $\mathrm{X}$ & & & $\begin{array}{l}147,461,482, \\
841\end{array}$ \\
\hline $\begin{array}{l}\text { Echinostoma } \\
\text { ilocanum }\end{array}$ & Intestine & & & $\mathrm{X}$ & & $\begin{array}{l}48,147,276 \\
290,482\end{array}$ \\
\hline $\begin{array}{l}\text { Reptiliotrema } \\
\text { primata }\end{array}$ & Intestine & & & $\mathrm{X}$ & & $147,290,482$ \\
\hline \multicolumn{7}{|l|}{ Notocotylids } \\
\hline $\begin{array}{l}\text { Ogmocotyle } \\
\text { ailuri }\end{array}$ & Sm. intestine & & & $\mathrm{X}$ & & 482 \\
\hline $\begin{array}{l}\text { Ogmocotyle } \\
\text { indica }\end{array}$ & Sm. intestine & & & $\mathrm{X}$ & & $\begin{array}{l}147,290,339, \\
482,490,927\end{array}$ \\
\hline
\end{tabular}


TABLE 45.6. (Continued).

\begin{tabular}{|c|c|c|c|c|c|c|}
\hline $\begin{array}{c}\text { Parasite } \\
\text { genus-species }\end{array}$ & $\begin{array}{l}\text { Location in } \\
\text { host }\end{array}$ & $\begin{array}{l}\text { Pro- } \\
\text { simians }\end{array}$ & $\begin{array}{l}\text { New World } \\
\text { monkeys }\end{array}$ & $\begin{array}{l}\text { Old World } \\
\text { monkeys }\end{array}$ & $\begin{array}{l}\text { Great } \\
\text { apes }\end{array}$ & References \\
\hline \multicolumn{7}{|l|}{ Troglotrematids } \\
\hline $\begin{array}{l}\text { Paragonimus } \\
\text { westermani }\end{array}$ & $\begin{array}{l}\text { Lungs, pleural } \\
\text { cavity, dia- } \\
\text { phragm, body } \\
\text { cavity, brain }\end{array}$ & & & $\mathrm{X}$ & & $\begin{array}{l}147,276,288, \\
290,362,606, \\
742,761,810\end{array}$ \\
\hline $\begin{array}{l}\text { Paragonimus } \\
\text { africanus }\end{array}$ & Lungs & & & $\mathrm{X}$ & & 744 \\
\hline Achillurbainia sp. & Parotid gld. & $\mathrm{x}$ & & & & 655 \\
\hline \multicolumn{7}{|l|}{ Schistosomatids } \\
\hline $\begin{array}{l}\text { Schistosoma } \\
\quad \text { bovis }\end{array}$ & $\begin{array}{l}\text { Mesenteric and } \\
\text { abdominal veins }\end{array}$ & & & $\mathrm{X}$ & & 482 \\
\hline $\begin{array}{l}\text { Schistosoma } \\
\text { haematobium }\end{array}$ & $\begin{array}{l}\text { Mesenteric, } \\
\text { visceral, and } \\
\text { abdominal veins }\end{array}$ & & & $\mathrm{X}$ & $\mathrm{X}$ & $\begin{array}{l}147,170,227 \\
276,290,482 \\
625,627,698\end{array}$ \\
\hline $\begin{array}{r}\text { Schistosoma } \\
\text { japonicum }\end{array}$ & $\begin{array}{l}\text { Mesenteric and } \\
\text { portal veins }\end{array}$ & & & $\mathrm{X}$ & $\mathrm{X}$ & $147,401,482$ \\
\hline $\begin{array}{l}\text { Schistosoma } \\
\text { mansoni }\end{array}$ & $\begin{array}{l}\text { Mesenteric and } \\
\text { abdominal veins }\end{array}$ & & $\mathrm{X}$ & $\mathrm{X}$ & $\mathrm{x}$ & $\begin{array}{l}124,147,227, \\
276,278,280, \\
290,367,402, \\
482,486,487, \\
498,507,587, \\
698,717,822, \\
832\end{array}$ \\
\hline $\begin{array}{l}\text { Schistosoma } \\
\text { mattheei }\end{array}$ & $\begin{array}{l}\text { Mesenteric and } \\
\text { abdominal veins }\end{array}$ & & & $\mathrm{X}$ & & $\begin{array}{l}49,276,482 \\
578,609,823\end{array}$ \\
\hline Schistosoma sp. & $\begin{array}{l}\text { Mesenteric and } \\
\text { abdominal veins }\end{array}$ & & & $\mathrm{X}$ & $\mathrm{X}$ & 482 \\
\hline \multicolumn{7}{|l|}{ Diplostomatids } \\
\hline $\begin{array}{l}\text { Diplostomid } \\
\quad \text { mesocercariae }\end{array}$ & $\begin{array}{l}\text { Visceral and } \\
\text { pulmonary cysts }\end{array}$ & & $\mathrm{X}$ & $\mathrm{X}$ & & 482 \\
\hline $\begin{array}{l}\text { Neodiplostomum } \\
\text { tamarini }\end{array}$ & Intestine & & $\mathrm{X}$ & & & $\begin{array}{l}147,148,193 \\
290,461,482\end{array}$ \\
\hline \multicolumn{7}{|l|}{ Paramphistomids } \\
\hline Chiorchis noci & Intestine & & & $\mathrm{X}$ & & $147,290,482$ \\
\hline $\begin{array}{l}\text { Gastrodiscoides } \\
\text { hominis }\end{array}$ & Cecum, colon & & & $\mathrm{X}$ & & $\begin{array}{l}147,276,290, \\
339,362,380, \\
403,482,660, \\
662,658,695, \\
712,764,791, \\
904\end{array}$ \\
\hline $\begin{array}{l}\text { Watsonius } \\
\quad \text { deschiensi }\end{array}$ & Intestine & & & $\mathrm{X}$ & & $\begin{array}{l}147,276,290 \\
482,609,742 \\
791\end{array}$ \\
\hline $\begin{array}{r}\text { Watsonius } \\
\text { watsoni }\end{array}$ & Intestine & & & $\mathrm{X}$ & & $\begin{array}{l}147,276,280 \\
290,339,362, \\
482,609,742, \\
791\end{array}$ \\
\hline $\begin{array}{c}\text { Watsonius } \\
\text { macaci }\end{array}$ & Intestine & & & $\mathrm{X}$ & & $\begin{array}{l}147,276,290 \\
362,482,791\end{array}$ \\
\hline
\end{tabular}




\section{PARAGONIMIASIS}

This disease, caused by the oriental lung fluke Paragonimus westermanii, has been reported in the cynomolgus monkey. Infection is directly associated with this animal's ingestion of infected raw crabs or crayfish as part of its dietary regimen $[276,288,290,362,606,742,761,810]$.

The adult flukes have a brown, plump, ovoid body with scalelike spines. The eggs are oval shaped, golden-brown in color, and have a partly flattened operculum at one end. The life cycle is indirect with snails and crabs or crayfish serving as intermediate hosts $[276,290,791]$.

Adult flukes are found primarily in the lung but sometimes occur in ectopic sites such as the brain, liver, and other organs. The clinical signs reported in infected animals include coughing, wheezing, bloody or rusty-tinged sputum, moist rales, and progressive emaciation [290, 791].

At necropsy, lesions consist of focal areas of emphysema and soft, dark red to brown cysts that measure $2-3 \mathrm{~cm}$ in diameter and are randomly located throughout the pulmonary parenchyma. These cysts may be elevated above the lung surface, and pleural adhesions can sometimes be present. Two or more flukes occupy each cyst $[290,482,791]$.

Histopathologically, the presence of the flukes provokes a leukocytic infiltration, and there is usually a mature fibrous capsule around the parasites that in turn are surrounded by a purulent exudate containing blood and groups of typicalappearing fluke eggs. Hemorrhage into the cyst often occurs, and this may lead to hemoptysis. Additional lesions described include hyperplasia of bronchial epithelium and submucosal glands and focal areas of inflammation in the lung parenchyma associated with groups of fluke eggs [290, 482, 791].

The diagnosis depends on the demonstration and identification of the typical eggs in the feces or the adult flukes in the pulmonary tissue at necropsy $[290,482$, 7911.

Paragonimus westermanii can affect humans; however, because of the obligatory molluscan and crustacean intermediate hosts in the life cycle, infected captive nonhuman primates are not a direct health hazard for humans [290, 482].

\section{SCHISTOSOMIASIS}

Several species of schistosomatid flukes have been reported to infect nonhuman primates naturally. These include Schistosoma mansoni in New World monkeys (squirrel monkeys) [482, 832], Old World monkeys (mangabeys, patas monkeys, guenons, and baboons) $[124,227,276,278,280,290,482,487,498,587,698$, $791,822]$, and the great apes (chimpanzees) [367, 402, 482, 717, 791]; Schistosoma haematobium in Old World monkeys (mangabeys, guenons, and baboons) $[227,276,290,482,625,627,698,791]$ and the great apes (chimpanzees) [170, 290, 482]; and Schistosoma mattheei in Old World monkeys (baboons) [49, 276, $482,578,609,791,823]$. Although schistosomatids are considered to be extremely serious pathogens for humans, they are of little consequence in captive nonhuman primates and are usually found incidentally at necropsy [290, 487].

In the schistosomatids, both male and female forms are present and differ in appearance. They are usually found together in constant copulation with the long, slender female in the sex canal of the short, muscular male. The egg of $S$. mansoni is elongated-ovoid in shape, rounded at both ends, and bears a lateral 
spine. The egg of S. haematobium is also elongated-ovoid in shape, rounded at the anterior end, and bears a posterior terminal spine. Adult Schistosoma mansoni and Schistosoma mattheei inhabit the mesenteric veins, whereas Schistosoma haematobium adults are found in the pelvic or portal veins of susceptible hosts [290, 791].

The life cycle is indirect with snails serving as intermediate hosts [290, 791].

The reported clinical signs include pyrexia, hemorrhagic diarrhea or hematuria, and ascites $[276,290,482,791]$. The principal pathologic effects are caused by the presence of eggs in the tissues [276, 290, 428, 482]. The eggs may be found almost anywhere in the abdominal or pleural cavities. The most frequently encountered lesion is thickening of the intestinal or urinary bladder walls caused by chronic inflammation. Microgranulomas surrounding typical schistosome eggs are also very common in the liver, brain, spleen, wall of the gastrointestinal tract and urinary bladder, and other organs. Continued insult can lead to stenosis of portions of the gastrointestinal tract, urinary bladder and other parts of the urogenital system, and cirrhosis of the liver [171, 276, 290, 428, $482,698]$.

Diagnosis is made based on the finding and identification of the characteristic eggs in the feces or urine, the presence of adult schistosomes in the blood vessels at necropsy, or the finding of the typical lesions during histopathological examination of appropriate tissues [290, 482, 791].

Infected captive nonhuman primates are not of direct public health significant to humans because of the requirement for an obligatory molluscan intermediate host. However, because schistosomiasis is such an important and serious disease in humans, excreta from nonhuman primates should be decontaminated before disposal [290].

\section{ATHESMIASIS}

The cause of this disease, Athesmia foxi, is considered to be a moderately pathogenic fluke that inhabits the bile ducts of susceptible nonhuman primate species. It is a common finding in nonhuman primates obtained from South America and has been reported in a variety of New World monkeys (cebus monkeys, squirrel monkeys, tamarins, and titi monkeys) $[59,147,235,275,280,290,311,333$, $461,689,742,824]$.

The adult flukes are long and slender and measure $8.5 \times 0.7 \mathrm{~mm}$. Eggs are ovoid and golden-brown in color; they have a thick shell and are operculated $[290,791,824]$.

The life cycle is indirect with a mollusk serving as a required intermediate host. However, because the method of infection of the vertebrate host is unknown, our knowledge about the life cycle of this particular fluke is incomplete [290, 791].

Infections in nonhuman primates are usually asymptomatic and most often considered an incidental finding. Aside from causing a moderate to marked distension of affected ducts, these parasites cause very little damage and do not invoke much of a host inflammatory response. Heavy infections can result in hyperplasia of the biliary epithelium and fibroplasia around eggs and the ducts. Extremely severe infections can result in a pronounced thickening of the bile ducts with resultant pressure and trauma to adjacent hepatic parenchyma leading to fatty degeneration of affected hepatocytes $[59,235,290,311,461,481,742$, $791,824]$. 
Diagnosis depends on the demonstration and identification of the adult flukes in the bile duct either at necropsy or on histopathological examination of liver sections, or by demonstration and identification of the characteristic eggs in the feces $[290,791]$.

Nonhuman primates infected with $A$. foxi do not pose any public health problems for humans. This parasite has not been reported from humans. Infected nonhuman primates are not a direct hazard to humans because of the need of a required molluscan intermediate host to complete the life cycle $[280,290]$.

\section{Cestodes}

\section{Cestodiasis}

This condition results from infection by one of any of the numerous tapeworm genera that have been described in the intestinal tract of nonhuman primates, including prosimians, New and Old World monkeys, and great apes [151, 202, $204,222,280,290,362,365,461,486,487,578,608,654,687,712,771,774$, $825,826,832,836,862,908,918]$. Cestode genera and the primate group they parasitize are listed in Table 45.7. Life cycles for all the genera listed, except one, are indirect and require an arthropod intermediate host for completion of the cycle. Hymenolepis nana can complete its life cycle either through direct or indirect means [290, 461].

Although these parasites may be present in large numbers, clinical disease or enteric lesions are seldom associated with tapeworm infection. Diagnosis depends on the identification of characteristic eggs in the feces, passing of proglottids of adult worms, or the recovery of adult worms at necropsy [290].

Some tapeworm genera (Hymenolepis, Raillietina, Bertiella) rarely affect humans. Proper precautions in handling captive nonhuman primates, good personal hygiene by the caretakers, and care in disposing of bedding and feces of infected animals should be stressed in order to rule out accidental transfer of infection to humans [290].

\section{Larval Cestodiasis}

Nonhuman primates may serve as intermediate hosts for several species of tapeworm parasites and thus develop various larval forms of these parasites in their somatic tissues. The larval cestode species and the primate group they parasitize are listed in Table 45.7. The cestode larvae are classified as solid and bladder forms. The solid larvae are represented by the sparganum. The bladder larvae consist of cysticercus, coenurus, hydatid, and tetrathyridium.

\section{Sparganosis}

This term denotes infection with the elongate, nonspecific plerocercoid larvae of cestodes in the order Pseudophylloidea [461, 791]. The adult tapeworms belong to the genera Diphylobothrium and Spirometra, which are intestinal parasites of various carnivores, birds, and reptiles [608].

Spargana have been described in New World monkeys (squirrel monkeys and marmosets) [148, 204, 207, 290, 461, 608], Old World monkeys (rhesus monkeys, cynomolgus monkeys, vervets, baboons, and talapoin monkeys) $[290,495$, $600,609,610]$, and prosimians (tree shrew) [771]. These larvae are solid with a 
TABLE 45.7. Parasitic cestodes described from nonhuman primates.

\begin{tabular}{|c|c|c|c|c|c|c|}
\hline $\begin{array}{c}\text { Parasite } \\
\text { genus-species }\end{array}$ & $\begin{array}{l}\text { Location in } \\
\text { host }\end{array}$ & $\begin{array}{c}\text { Pro- } \\
\text { simians }\end{array}$ & $\begin{array}{c}\text { New World } \\
\text { monkeys }\end{array}$ & $\begin{array}{c}\text { Old World } \\
\text { monkeys }\end{array}$ & $\begin{array}{l}\text { Great } \\
\text { apes }\end{array}$ & References \\
\hline $\begin{array}{l}\text { Anoplocephalids } \\
\text { Bertiella studeri }\end{array}$ & Sm. intestine & & & $\mathrm{X}$ & $\mathrm{X}$ & $\begin{array}{l}32,276,290, \\
362,461,485, \\
486,487,494, \\
578,608,712, \\
791,825,836, \\
862,908,922\end{array}$ \\
\hline $\begin{array}{l}\text { Bertiella } \\
\quad \text { mucronata }\end{array}$ & Sm. intestine & & $\mathrm{X}$ & & $\mathrm{X}$ & $\begin{array}{l}32,151,204, \\
280,290,608 \\
682,689\end{array}$ \\
\hline Bertiella fallax & Sm. intestine & & $\mathrm{X}$ & & & $\begin{array}{l}204,280,290, \\
608\end{array}$ \\
\hline Bertiella satyri & Sm. intestine & & $\mathrm{X}$ & $\mathrm{X}$ & & 113 \\
\hline Bertiella okabei & Sm. intestine & & & $\mathrm{X}$ & & 765 \\
\hline Bertiella sp. & Sm. intestine & & & $\mathrm{X}$ & $\mathrm{X}$ & $\begin{array}{l}151,480,491, \\
570,616,654, \\
660,764\end{array}$ \\
\hline $\begin{array}{l}\text { Anaplocephala } \\
\text { sp. }\end{array}$ & Sm. intestine & & & & $\mathrm{X}$ & 608,753 \\
\hline Parabertiella sp. & Sm. intestine & & & $\mathrm{X}$ & & $\begin{array}{l}3,658,660, \\
662\end{array}$ \\
\hline $\begin{array}{r}\text { Moniezia } \\
\text { rugosa }\end{array}$ & Sm. intestine & & $\mathrm{X}$ & & & $\begin{array}{l}204,280,290 \\
461,608\end{array}$ \\
\hline Thysanotaenia sp. & Sm. intestine & $\mathrm{X}$ & & & & 608,918 \\
\hline $\begin{array}{l}\text { Tupaiataenia } \\
\text { quentini }\end{array}$ & Sm. intestine & $\mathrm{X}$ & & & & 771 \\
\hline $\begin{array}{l}\text { Intermicapsifer } \\
\mathrm{sp} .\end{array}$ & Sm. intestine & & & $\mathrm{X}$ & & 539,608 \\
\hline $\begin{array}{l}\text { Atriotaenia } \\
\quad \text { megastoma }\end{array}$ & Sm. intestine & $\mathrm{x}$ & $\mathrm{x}$ & & & $\begin{array}{l}148,168,204, \\
290,311,461, \\
608,623\end{array}$ \\
\hline $\begin{array}{c}\text { Matheovataenia } \\
\text { brasiliensis }\end{array}$ & Sm. intestine & & $\mathrm{X}$ & & & 478 \\
\hline $\begin{array}{l}\text { Matheovataenia } \\
\text { curzsilvai }\end{array}$ & Sm. intestine & & & $\mathrm{X}$ & & 582 \\
\hline $\begin{array}{l}\text { Matheovataenia } \\
\text { sp. }\end{array}$ & Sm. intestine & & $\mathbf{X}$ & & & $31,461,608$ \\
\hline \multicolumn{7}{|l|}{ Davaineids } \\
\hline $\begin{array}{l}\text { Rallietina } \\
\quad \text { alouattae }\end{array}$ & Sm. intestine & & $\mathrm{X}$ & & & $\begin{array}{l}204,290,608, \\
742\end{array}$ \\
\hline $\begin{array}{l}\text { Rallietina } \\
\quad \text { demerariensis }\end{array}$ & Sm. intestine & & $X$ & & & $\begin{array}{l}32,204,290 \\
482,841\end{array}$ \\
\hline Rallietina sp. & Sm. intestine & $\mathrm{X}$ & $\mathrm{X}$ & & & $\begin{array}{l}168,290,461 \\
608,623\end{array}$ \\
\hline $\begin{array}{l}\text { Paratriotaeniids } \\
\text { Paratriotaenia } \\
\text { oedipomidatus }\end{array}$ & Sm. intestine & & $\mathrm{X}$ & & & $\begin{array}{l}207,290,461 \\
608,689,826\end{array}$ \\
\hline \multicolumn{7}{|l|}{ Dilepidids } \\
\hline Dilepis sp. & Sm. intestine & & & $\mathbf{x}$ & & 608 \\
\hline $\begin{array}{l}\text { Choanotaenia } \\
\text { infundibulum }\end{array}$ & Sm. intestine & & & $\mathrm{X}$ & & 425 \\
\hline
\end{tabular}


TABLE 45.7. (Continued).

\begin{tabular}{|c|c|c|c|c|c|c|}
\hline $\begin{array}{c}\text { Parasite } \\
\text { genus-species }\end{array}$ & $\begin{array}{l}\text { Location in } \\
\text { host }\end{array}$ & $\begin{array}{l}\text { Pro- } \\
\text { simians }\end{array}$ & $\begin{array}{c}\text { New World } \\
\text { monkeys }\end{array}$ & $\begin{array}{c}\text { Old World } \\
\text { monkeys }\end{array}$ & $\begin{array}{l}\text { Great } \\
\text { apes }\end{array}$ & References \\
\hline \multicolumn{7}{|l|}{ Hymenolepidids } \\
\hline $\begin{array}{l}\text { Hymenolepis } \\
\text { nana }\end{array}$ & Sm. intestine & & $\mathrm{x}$ & $\mathrm{x}$ & $\mathrm{X}$ & $\begin{array}{l}38,276,290 \\
349,461,584 \\
608,742,764 \\
791,808,880\end{array}$ \\
\hline $\begin{array}{l}\text { Hymenolepis } \\
\text { diminuta }\end{array}$ & Sm. intestine & $\mathrm{X}$ & & $\mathrm{X}$ & & $\begin{array}{l}276,290,349 \\
461,608,742, \\
764,771,791 \\
880\end{array}$ \\
\hline $\begin{array}{r}\text { Hymenolepis } \\
\text { cebidarum }\end{array}$ & Sm. intestine & & $\mathrm{X}$ & & & $204,290,623$ \\
\hline Hymenolepis sp. & Sm. intestine & $\mathrm{X}$ & & & $\mathrm{X}$ & $\begin{array}{l}61,387,570 \\
764,922\end{array}$ \\
\hline Vampirolepis sp. & Sm. intestine & & $\mathrm{X}$ & & & 461,608 \\
\hline \multicolumn{7}{|l|}{ Mesocestoidids } \\
\hline $\begin{array}{l}\text { Mesocestoides sp. } \\
\text { (Tetrathyridium) }\end{array}$ & $\begin{array}{l}\text { Larva: } \\
\text { peritoneal cavity }\end{array}$ & & & $\mathrm{X}$ & $\mathrm{X}$ & $\begin{array}{l}245,290,339 \\
608,609,712 \\
715,751,911\end{array}$ \\
\hline \multicolumn{7}{|l|}{ Taeniids } \\
\hline $\begin{array}{c}\text { Taenia crocutae } \\
\text { (Cysticercus) }\end{array}$ & $\begin{array}{l}\text { Larva: skeletal } \\
\text { muscle }\end{array}$ & & & $\mathrm{X}$ & & 578 \\
\hline $\begin{array}{l}\text { Taenia } \\
\text { hydatigena } \\
\text { (Cysticercus } \\
\text { tenuicollis) }\end{array}$ & $\begin{array}{l}\text { Larva: liver, } \\
\text { peritoneal cavity }\end{array}$ & & & $\mathrm{X}$ & & $\begin{array}{l}32,280,290 \\
339,488,506 \\
507,608,609 \\
810\end{array}$ \\
\hline $\begin{array}{c}\text { Taenia solium } \\
\text { (Cysticercus } \\
\text { cellulosae) }\end{array}$ & $\begin{array}{l}\text { Larva: brain, } \\
\text { heart, muscle, } \\
\text { subcutis }\end{array}$ & & & $\mathrm{X}$ & $\mathrm{X}$ & $\begin{array}{l}32,280,290 \\
507,608,609 \\
742,745,870 \\
876\end{array}$ \\
\hline $\begin{array}{l}\text { Multiceps } \\
\quad \text { serialis } \\
\text { (Coenurus } \\
\text { serialis) }\end{array}$ & Larva: subcutis & & & $\mathrm{X}$ & & $\begin{array}{l}32,226,290 \\
742\end{array}$ \\
\hline $\begin{array}{l}\text { Multiceps brauni } \\
\quad \text { (coenurus) }\end{array}$ & $\begin{array}{l}\text { Larva: subcutis, } \\
\text { pleural and } \\
\text { abdominal cavi- } \\
\text { ties, brain }\end{array}$ & & & $\mathrm{X}$ & & $32,248,290$ \\
\hline $\begin{array}{l}\text { Echinococcus } \\
\text { granulosus } \\
\text { (Hydatid cyst) }\end{array}$ & $\begin{array}{l}\text { Larva: liver, } \\
\text { lungs, peri- } \\
\text { toneal cavity }\end{array}$ & $\mathrm{X}$ & $\mathrm{X}$ & $\mathrm{x}$ & $\mathrm{X}$ & $\begin{array}{l}7,32,44,55, \\
152,179,224, \\
276,290,309, \\
366,397,398, \\
408,461,501, \\
614,615,640, \\
663,664,691, \\
780,810,830\end{array}$ \\
\hline $\begin{array}{l}\text { Diphyllobothriids } \\
\text { Diphyllobothrium } \\
\quad \text { erinacei } \\
\text { (sparganum) }\end{array}$ & $\begin{array}{l}\text { Larva: subcutis, } \\
\text { muscle }\end{array}$ & & $\mathrm{X}$ & $\mathrm{X}$ & & $\begin{array}{l}32,148,204 \\
280,290,509 \\
609,742,810\end{array}$ \\
\hline
\end{tabular}


TABLE 45.7. (Continued).

\begin{tabular}{|c|c|c|c|c|c|c|}
\hline $\begin{array}{c}\text { Parasite } \\
\text { genus-species }\end{array}$ & $\begin{array}{l}\text { Location in } \\
\text { host }\end{array}$ & $\begin{array}{l}\text { Pro- } \\
\text { simians }\end{array}$ & $\begin{array}{l}\text { New World } \\
\text { monkeys }\end{array}$ & $\begin{array}{l}\text { Old World } \\
\text { monkeys }\end{array}$ & $\begin{array}{l}\text { Great } \\
\text { apes }\end{array}$ & References \\
\hline $\begin{array}{l}\text { Spriometra } \\
\text { reptans } \\
\text { (sparganum) }\end{array}$ & Larva: subcutis & & $\mathrm{X}$ & & & $204,207,290$ \\
\hline $\begin{array}{l}\text { Spirometra sp. } \\
\text { (sparganum) }\end{array}$ & $\begin{array}{l}\text { Larva: } \\
\text { abdominal cav- } \\
\text { ity, subcutis, } \\
\text { muscle }\end{array}$ & $\mathrm{X}$ & & $\mathrm{X}$ & & $\begin{array}{l}61,290,495, \\
578,600,610, \\
771,911\end{array}$ \\
\hline
\end{tabular}

scolex that contains a pseudosucker. They are white, ribbonlike, and of variable size and motility. They resemble the adult except they lack proglotids and mature genitalia. Spargana can vary from a few millimeters to several centimeters in length [608, 791, 847]. In nonhuman primates, spargana may be found in any part of the body: in retroperitoneal tissues, in abdominal or pleural cavities, or in subcutaneous and muscular tissues. They are commonly encased by a connective tissue capsule, and they do not incite much of an inflammatory response unless they die. These degenerating larvae may cause local inflammation and edema. Most infections in nonhuman primates are usually asymptomatic, and their presence is considered to be an incidental finding at necropsy $[608,791]$.

Diagnosis can be made in the live animal by radiography, which may reveal calcified nodules. Also, one may palpate mobile nodules in the subcutaneous tissue with localized edema. In the dead animal, diagnosis is made through demonstration and identification of the characteristic spargana larvae either grossly at necropsy or microscopically in histopathologic specimens [608, 791].

\section{Cystricercosis}

This condition is the result of infection with the larval form of various members of the family Taeniidae. Adult tapeworms of this family commonly parasitize birds and mammals $[461,608]$. Cystericerci have been described in New World monkeys (squirrel monkeys and marmosets) [461], Old World monkeys (rhesus monkeys, baboons, mangabeys, patas monkeys, langurs, and vervets) [280, 290, $339,608,609,742,870,876]$, great apes (gibbons and chimpanzees) $[608,745$, 922], and prosimians (lemur) [86, 384, 608]. Cysticerci are oval, translucent cysts that contain a single invaginated scolex with four suckers. In those species that have them, a circle of hooks is present $[461,608,847]$. These cysts may be found in the abdominal or thoracic cavities, muscle, subcutaneous tissue, and central nervous system. Usually there is very little host inflammatory reaction to the presence of viable cysts. As the cysts enlarge, there may be compression of adjacent tissues. Dead cysts will provoke an intense chronic inflammatory reaction $[461,608,870]$.

Symptoms in nonhuman primates are directly related to the tissue in which the cysticercus develops and the number present [608]. Involvement of the central nervous system can produce neurological disorders, but this appears to be less of a problem in infected nonhuman primates than in cerebral cysticercosis in the human patient $[608,870,876]$. 
Diagnosis depends upon the finding of the characteristic bladder-shaped structure in the tissues. Identification of the specific species involved is based on the characteristic hook size and structure [608].

\section{Coenurosis}

This condition is the result of infection with the larval form of the tapeworms Multiceps multiceps or Multiceps serialis, which are intestinal cestodes of dogs and related carnivores [290, 461]. Coenurosis has been reported in Old World monkeys (macaques, vervets, gelada baboon, and other baboons) [133, 226, 248, $290,489,501,608,700,735,742,757,860$ ] and prosimians (lemur) [608].

The coenurus is a polycephalid larval form that produces both internal and external daughter cysts. The inner layer of the cyst wall is composed of germinal epithelium from which numerous scolices develop [290, 608, 847].

Coenuri have been described in the subcutaneous tissues, peritoneal cavity, liver, brain, and other organs of affected nonhuman primates $[290,461,608$, 757]. Clinical signs and histopathology depend on the number of coenuri present and their location. In general, infection in nonhuman primates has produced minimal symptoms and lesions $[226,501,608,700,735,860]$. However, in those cases where there is involvement of the central nervous system, typical neurological symptoms are observed $[608,860]$.

Diagnosis can be made by radiography or the finding of a tumorlike mass in the subcutaneous tissues. Identification of the species of cestode is based on the hook structure of the scolex $[290,608]$.

\section{Hydatidosis}

This disease, also known as echinococcosis, is the result of infection by the larval stage of cestode parasites in the genus Echinococcus. The adult tapeworms are found in the intestinal tract of dogs, wolves, bush dogs, other members of the canine family, and related carnivores $[290,461,608]$. Hydatid cysts caused by $E$. granulosus have been described from a number of Old World monkeys (guenons, colobus monkey, mangabeys, mandrills, rhesus monkeys, other macaques, Celebes ape, and baboons) $[7,55,152,179,200,224,290,366,397,408,501$, $608,614,615,663,664,691,830$ ], New World monkeys (marmoset) [461], great apes (chimpanzee, gorilla, and orangutan) [44, 309, 640], and prosimians (galago and lemurs) $[290,663,780]$. Recently, hydatid cysts from the tapeworm $E$. vogeli have been reported from a group of young great apes (gorillas, orangutans, and chimpanzees) [398].

Hydatid cysts are large, unilocular cysts. The inner layer of the cyst wall is composed of germinal epithelium from which numerous brood capsules develop. Multiple scolices then develop from the wall of the brood capsule. The cyst wall of $E$. granulosa is characteristically laminated and composed of a thick hyaline material [290, 461, 791, 847].

Hydatid cysts may be located in the abdominal cavity, liver, lungs, subcutis, or throughout the body $[152,179,200,290,408,461,608,615,691,791]$. The size of the cyst and the amount of involvement and host reaction depends on its age and the location within the host. Abdominal distension or localized subcutaneous swellings are sometimes seen, but usually the presence of the cysts 
causes no clinical signs or ill effects and they are found incidentally at necropsy $[152,290,366,507,608,791,830]$.

The gross appearance of the cyst is that of a varying sized, spherical mass, usually in the liver, but it may sometimes be embedded in the lungs or be free in the abdominal cavity. Rupture of pulmonary hydatid cysts and resulting anaphylactic shock have been suggested as the cause of death in several cases of echinococcosis in nonhuman primates [7, 608, 705]. Free scolices from ruptured cysts can implant in other tissues and produce additional cysts [608].

The diagosis of hydatidosis is usually not made until after the cyst reaches considerable size. Symptoms may mimic a neoplasm. Radiographs can be helpful in detecting the presence of pulmonary or calcified hepatic cysts. However, pulmonary changes can be mistaken for tuberculosis or neoplasia. Serological tests such as the Casoni intradermal skin test or tanned cell hemagglutination test are of value in the diagnosis of hydatid disease in nonhuman primates. Specific identification is based on the finding of detached scolices, or daughter cysts, in the cyst fluid. The hook is considered characteristic for the genus. If scolices are not present, the histomorphology of the cyst wall can be used as identifying criteria $[152,290,430,608,791]$. Abdominal ultrasonic scanning has been used successfully in diagnosing echinococcosis in gorillas [640].

\section{Tetrathyridiosis}

This condition results from infection with the larval stage of cestode parasites in the genus Mesocestoides. The adult tapeworms of this genus parasitize various birds and mammals [290, 608, 791]. It has been described in Old World monkeys (rhesus monkeys, guenons, cynomolgus monkeys, and baboons) [245, 290, 339, $608,609,712,715]$ and great apes (gibbon) [751], but its occurrence in nonhuman primates is considered to be uncommon or even rare [290].

The tetrathyridial larva is flat and has an extremely contractile body. They may be confused with spargana. The anterior end is knotlike and contains an invaginated holdfast apparatus with four suckers. Length can vary from 2 to $70 \mathrm{~mm}$,

TABLE 45.8. Parasitic acanthocephalans described from nonhuman primates.

\begin{tabular}{|c|c|c|c|c|c|c|}
\hline $\begin{array}{c}\text { Parasite } \\
\text { genus-species }\end{array}$ & $\begin{array}{l}\text { Location in } \\
\text { host }\end{array}$ & $\begin{array}{l}\text { Pro- } \\
\text { simians }\end{array}$ & $\begin{array}{l}\text { New World } \\
\text { monkeys }\end{array}$ & $\begin{array}{l}\text { Old World } \\
\text { monkeys }\end{array}$ & $\begin{array}{l}\text { Great } \\
\text { apes }\end{array}$ & References \\
\hline $\begin{array}{l}\text { Moniliformis } \\
\text { moniliformis }\end{array}$ & Sm. intestine & & & & $\mathrm{X}$ & $\begin{array}{l}29,290,461, \\
742,770,791 \text {, } \\
909,922\end{array}$ \\
\hline $\begin{array}{l}\text { Prosthenorchis } \\
\text { elegans }\end{array}$ & $\begin{array}{l}\text { Ileum, cecum, } \\
\text { colon }\end{array}$ & & $\mathrm{X}$ & & & $\begin{array}{l}26,33,115, \\
167,168,204, \\
219,290,311, \\
461,552,623, \\
689,720,742, \\
770,791,834, \\
841,915\end{array}$ \\
\hline $\begin{array}{l}\text { Prosthenorchis } \\
\text { spirula }\end{array}$ & $\begin{array}{l}\text { Ileum, cecum, } \\
\text { colon }\end{array}$ & $X$ & $X$ & & & $\begin{array}{l}83,115,204, \\
290,623,689, \\
742,770,791, \\
841\end{array}$ \\
\hline
\end{tabular}


depending on the species of cestode and species of host. The tetrathyridum is proglotted shaped in the monkey $[290,339,608,791]$.

These larvae usually are found free in the serous cavities of the body or are found encysted in various tissues. Tetrathyridum evokes little host response and is usually considered to be an incidental finding in nonhuman primates [245, 290, $339,608,791]$.

Diagnosis depends on demonstration and identification of the characteristic larval form in the body cavities or encysted in the host tissues [290, 608, 791].

Larval cestodes in nonhuman primates are of little public health importance to humans because infection can occur only by ingestion of the larval form. Of more importance to both humans and captive nonhuman primates is the possible ingestion of eggs passed by the infected definitive host. For this reason, feces from domestic and feral canids should be handled and disposed of with extreme care. Control of these parasites can only be accomplished through programs aimed at eliminating them from the definitive host [290].

\section{Acanthocephalans}

The parasitic acanthocephalans described in the alimentary tract of nonhuman primates are listed in Table 45.8. Those species most frequently encountered in nonhuman primates are discussed below.

\section{ACANTHOCEPHALIASIS}

This disease in nonhuman primates is most frequently the result of infection with acanthocephalan parasites in the genus Prosthenorchis. These parasites are distributed throughout Central and South America and have been reported in a variety of New World monkeys. Prosimians, Old World primates, and great apes can become infected under laboratory or captive conditions [115, 204, 290, 742, 770]. The species involved are $P$. elegans, which inhabits the cecum or colon, and $P$. spirula, which favors the terminal ileum $[115,168,204,207,290,311,461$, $552,583,623,632,720,742,770,791,827,834,866]$.

The life cycle is indirect with cockroaches and beetles acting as the intermediate hosts $[229,290,339,461,631,770,791]$.

Diagnosis depends upon identification of the characteristic thick-walled eggs or, more rarely, the worm itself in the feces. Conventional fecal flotation methods are ineffective as a means of demonstrating the eggs of these worms; fecal smears or sedimentation techniques must be used. At necropsy the finding of typical "thorny-headed worms" attached to the intestinal mucosa is considered diagnostic [168, 290, 461, 770, 791].

No distinctive symptoms accompany infection with acanthocephalans. Suspected cases must be confirmed by diagnostic methods. Clinical signs vary depending upon the severity of the infection. Diarrhea, anorexia, debilitation, and death all have been associated with acanthocephaliasis in New World monkeys. In cases of massive infection, there is often cachexia caused by secondary complications and perhaps pain, sometimes of sudden onset; death follows rapidly. Most often the parasite does not contribute directly to the animal's death, but rather produces lesions that allow secondary pathogens to become estab- 
TABLE 45.9. Leeches described from nonhuman primates.

\begin{tabular}{|c|c|c|c|c|c|c|}
\hline $\begin{array}{c}\text { Parasite } \\
\text { genus-species }\end{array}$ & $\begin{array}{l}\text { Location in } \\
\text { host }\end{array}$ & $\begin{array}{l}\text { Pro- } \\
\text { simians }\end{array}$ & $\begin{array}{l}\text { New World } \\
\text { monkeys }\end{array}$ & $\begin{array}{l}\text { Old World } \\
\text { monkeys }\end{array}$ & $\begin{array}{l}\text { Great } \\
\text { apes }\end{array}$ & References \\
\hline $\begin{array}{l}\text { Limnatus } \\
\text { africana }\end{array}$ & Nasal cavities & & & $\mathrm{X}$ & & $125,290,506$ \\
\hline Dinobdella ferox & $\begin{array}{l}\text { Nasal cavities, } \\
\text { pharynx }\end{array}$ & & & $\mathrm{X}$ & & $\begin{array}{l}93,276,290 \\
295,494,696\end{array}$ \\
\hline
\end{tabular}

lished, resulting in debilitation and the ultimate demise of the host $[115,168,290$, 461, 597, 718, 770, 791, 834].

Attachment of the proboscis of these parasites to the intestinal mucosa causes a pronounced, usually severe, granulomatous inflammatory response, and the nodules formed usually can be seen from the serosal surface. The proboscis often penetrates the mucosa and invades the muscular layers of the intestinal wall. If complete penetration of the intestinal wall occurs, a fatal peritonitis results. Adult parasites sometimes are found in the abdominal cavity. Severe infections can cause mechanical blockage of the intestinal tract, intussusception, or rectal prolapse. Under these circumstances, infected animals will be depressed and pass bright red blood and scanty feces $[167,168,204,290,311,461,583,623,720$, $770,791,834]$.

Histologically, a chronic, active inflammatory response is seen, with ulcers of the mucosa and granuloma and abscess formation in the intestinal wall associated with penetration of the proboscis and the resulting destruction of existing tissues. A focal suppurative to fibrinopurulent serositis also may be present in areas where the parasites approach penetration or actually rupture the intestinal wall [83, 290, 461, 770, 791]. A hepatic abscess and granulomatous myositis (diaphragm) associated with migration of an unidentified acanthocephalan has been reported from an adult bushbaby (Galago crassicaudatus) [78].

Infection with these parasites has not been reported in humans [290].

\section{Annelida}

The species of annelids that parasitize nonhuman primates are listed in Table 45.9 .

\section{DINOBDELLAIASIS}

The cause of this condition is the leech, Dinobdella ferox, which is distributed geographically throughout southern Asia [276, 290, 820]. It is a frequent parasite of the nasal cavities of macaques that range throughout this region of the world.

Dinobdella ferox has been reported from several Old World monkey species (rhesus monkeys and Formosan macaques) [93, 290, 295, 494, 696, 820].

The life cycle of this parasite is direct. Adults are hermaphroditic and eggs are laid in cocoons that are attached to objects at the surface of a pond. After hatching, the immature leeches stay at the water's surface. Infection of the host occurs during drinking; the leech enters the body through the oral or nasal cavities, attaches to the mucosa of the upper respiratory tract, sucks blood for periods that 
TABLE 45.10. Fleas described from nonhuman primates.

\begin{tabular}{|c|c|c|c|c|c|c|}
\hline $\begin{array}{c}\text { Parasite } \\
\text { genus-species }\end{array}$ & $\begin{array}{l}\text { Location in } \\
\text { host }\end{array}$ & $\begin{array}{l}\text { Pro- } \\
\text { simians }\end{array}$ & $\begin{array}{c}\text { New World } \\
\text { monkeys }\end{array}$ & $\begin{array}{c}\text { Old World } \\
\text { monkeys }\end{array}$ & $\begin{array}{l}\text { Great } \\
\text { apes }\end{array}$ & References \\
\hline $\begin{array}{l}\text { Ctenocephalides } \\
\text { felis }\end{array}$ & Hair, skin & $\mathrm{X}$ & & $\mathrm{X}$ & & $\begin{array}{l}281,290,609 \\
814\end{array}$ \\
\hline Tunga penetrans & Skin & & & $\mathrm{X}$ & $\mathrm{X}$ & $\begin{array}{l}280,281,290 \\
814\end{array}$ \\
\hline Pulex irritans & Hair, skin & & & $\mathrm{X}$ & & 290,931 \\
\hline $\begin{array}{l}\text { Ctenocephalides } \\
\text { canis }\end{array}$ & Hair, skin & & & $\mathrm{X}$ & & 281,814 \\
\hline $\begin{array}{c}\text { Echidnophaga } \\
\text { gallinacea }\end{array}$ & Skin & $\mathrm{X}$ & & & & 281,814 \\
\hline
\end{tabular}

may last a few days or many weeks, grows and matures, detaches, and drops out through the nostrils. The adult leeches are not parasitic [93, 290, 696].

Infection with a few parasites is usually asymptomatic, but heavy infection is reported to cause restlessness, epistaxis, anemia, weakness, asphyxiation, and sometimes death $[290,696,820]$. Histopathologically, the lesions are composed of a mild, focal, chronic inflammatory infiltrate, and increased mucus production involving the nasopharyngeal mucosa $[290,696,820]$. Diagnosis is based on recognizing and identifying the parasite in its typical anatomical location within the host $[290,696]$.

This leech presents some public health significance because it does attack humans; however, infection under laboratory conditions is improbable. Nevertheless, precautions should be taken when removing leeches from affected monkeys [290].

\section{Arthropods: Insecta}

The parasitic genera of Siphonaptera (fleas), Diptera (flies), and Mallophaga and Anoplura (lice) described from nonhuman primates are listed in Tables 45.10, 45.11 , and 45.12, respectively. The most important members of these Orders will be discussed in detail below.

TABLE 45.11. Flies described from nonhuman primates.

\begin{tabular}{|c|c|c|c|c|c|c|}
\hline $\begin{array}{c}\text { Parasite } \\
\text { genus-species }\end{array}$ & $\begin{array}{l}\text { Location in } \\
\text { host }\end{array}$ & $\begin{array}{l}\text { Pro- } \\
\text { simians }\end{array}$ & $\begin{array}{c}\text { New World } \\
\text { monkeys }\end{array}$ & $\begin{array}{l}\text { Old World } \\
\text { monkeys }\end{array}$ & $\begin{array}{l}\text { Great } \\
\text { apes }\end{array}$ & References \\
\hline Cuterebra sp. & Skin, subcutis & & $\mathrm{X}$ & $\mathrm{X}$ & & $281,290,792$ \\
\hline $\begin{array}{l}\text { Dermatobia } \\
\text { hominis }\end{array}$ & Skin, subcutis & & $X$ & & & 290,584 \\
\hline $\begin{array}{l}\text { Cordylobia } \\
\text { anthropophaga }\end{array}$ & Skin & & & $\mathrm{X}$ & & $280,281,290$ \\
\hline Alouattamyia sp. & Skin & & $\mathrm{X}$ & & & 207 \\
\hline $\begin{array}{l}\text { Cochliomyia } \\
\text { hominivorax }\end{array}$ & Skin & & & $\mathrm{X}$ & & 595 \\
\hline
\end{tabular}


TABLE 45.12. Lice described from nonhuman primates.

\begin{tabular}{|c|c|c|c|c|c|c|}
\hline $\begin{array}{c}\text { Parasite } \\
\text { genus-species }\end{array}$ & $\begin{array}{l}\text { Location in } \\
\text { host }\end{array}$ & $\begin{array}{l}\text { Pro- } \\
\text { simians }\end{array}$ & $\begin{array}{l}\text { New World } \\
\text { monkeys }\end{array}$ & $\begin{array}{l}\text { Old World } \\
\text { monkeys }\end{array}$ & $\begin{array}{l}\text { Great } \\
\text { apes }\end{array}$ & References \\
\hline \multicolumn{7}{|l|}{ Anoplurans } \\
\hline $\begin{array}{l}\text { Pedicinus } \\
\text { eurygaster }\end{array}$ & Hair & & & $\mathrm{X}$ & & $290,479,491$ \\
\hline Pedicinus obtusus & Hair & & & $\mathrm{X}$ & & $\begin{array}{l}290,479,491, \\
609\end{array}$ \\
\hline Pedicinus patas & Hair & & & $\mathrm{X}$ & & 290,479 \\
\hline $\begin{array}{l}\text { Pedicinus } \\
\text { hamadryas }\end{array}$ & Hair & & & $\mathrm{X}$ & & 290,609 \\
\hline $\begin{array}{l}\text { Pedicinus } \\
\text { mjobergi }\end{array}$ & Hair & & & $\mathrm{X}$ & & 290,682 \\
\hline Pedicinus schaeffi & Hair & & & $\mathrm{X}$ & $\mathrm{X}$ & $\begin{array}{l}281,290,396 \\
460,814\end{array}$ \\
\hline $\begin{array}{l}\text { Docophthirus } \\
\text { acionetus }\end{array}$ & Hair & $\mathrm{X}$ & & & & $\begin{array}{l}214,281,396, \\
814\end{array}$ \\
\hline $\begin{array}{l}\text { Phthiropediculus } \\
\text { propitheci }\end{array}$ & Hair & $\mathrm{X}$ & & & & $281,396,814$ \\
\hline $\begin{array}{l}\text { Lemurphthirus } \\
\text { galagus }\end{array}$ & Hair & $\mathrm{X}$ & & & & $281,396,814$ \\
\hline $\begin{array}{l}\text { Pediculus lobatus } \\
\text { pseudohumanus }\end{array}$ & Hair & & $\mathrm{X}$ & & & $281,396,814$ \\
\hline P. l. atelophilus & Hair & & $\mathrm{X}$ & & & $281,396,814$ \\
\hline $\begin{array}{r}\text { Harrisonia } \\
\text { uncinata }\end{array}$ & Hair & & $\mathrm{X}$ & & & $281,396,814$ \\
\hline Gliricola pintoi & Hair & & $\mathrm{X}$ & & & $281,396,814$ \\
\hline $\begin{array}{l}\text { Pediculus } \\
\text { humanus } \\
\text { friedenthali }\end{array}$ & Hair & & & & $\mathrm{X}$ & $281,396,814$ \\
\hline Phthirus pubis & Hair & & & & $\mathrm{X}$ & $281,396,814$ \\
\hline Phithirus gorillae & Hair & & & & $\mathrm{X}$ & $281,396,814$ \\
\hline $\begin{array}{l}\text { Pediculus } \\
\quad \text { humanus capitis }\end{array}$ & Hair & & $\mathrm{X}$ & & $\mathrm{x}$ & $\begin{array}{l}154,281,396, \\
814\end{array}$ \\
\hline Pediculus sp. & Hair & & $\mathrm{X}$ & & & 207,736 \\
\hline Sathrax durus & Hair & $\mathrm{X}$ & & & & 214 \\
\hline $\begin{array}{l}\text { Pedicinus } \\
\text { longiceps }\end{array}$ & Hair & & & $\mathrm{X}$ & & 491 \\
\hline \multicolumn{7}{|l|}{ Mallophagans } \\
\hline $\begin{array}{l}\text { Trichodectes } \\
\text { armatus }\end{array}$ & Hair & & $\mathrm{X}$ & & & 281,814 \\
\hline $\begin{array}{l}\text { Trichodectes } \\
\text { colobi }\end{array}$ & Hair & & & $\mathrm{X}$ & & 281,814 \\
\hline $\begin{array}{c}\text { Trichodectes } \\
\text { mjoebergi }\end{array}$ & Hair & $\mathrm{X}$ & & & & 281,814 \\
\hline $\begin{array}{l}\text { Trichodectes } \\
\text { semiarmatus }\end{array}$ & Hair & & $\mathrm{X}$ & & & 281,814 \\
\hline Trichodectes sp. & Hair & & $\mathrm{X}$ & & & 281,814 \\
\hline $\begin{array}{c}\text { Trichophilopterus } \\
\text { babakotophilus }\end{array}$ & Hair & $\mathrm{X}$ & & & & 218,814 \\
\hline $\begin{array}{c}\text { Tetragynopus } \\
\text { aotophilus }\end{array}$ & Hair & & $\mathrm{X}$ & & & 281,814 \\
\hline $\begin{array}{l}\text { Trichopilopterus } \\
\text { ferrisi }\end{array}$ & Hair & $\mathrm{x}$ & & & & 281,396 \\
\hline $\begin{array}{l}\text { Eutrichophilus } \\
\text { setosus }\end{array}$ & Hair & & & $\mathrm{X}$ & & 277,281 \\
\hline
\end{tabular}


TABLE 45.12. (Continued).

\begin{tabular}{|c|c|c|c|c|c|c|}
\hline $\begin{array}{c}\text { Parasite } \\
\text { genus-species }\end{array}$ & $\begin{array}{l}\text { Location in } \\
\text { host }\end{array}$ & $\begin{array}{l}\text { Pro- } \\
\text { simians }\end{array}$ & $\begin{array}{l}\text { New World } \\
\text { monkeys }\end{array}$ & $\begin{array}{l}\text { Old World } \\
\text { monkeys }\end{array}$ & $\begin{array}{l}\text { Great } \\
\text { apes }\end{array}$ & References \\
\hline $\begin{array}{l}\text { Aotiella } \\
\quad \text { aotophilus }\end{array}$ & Skin & & $\mathrm{X}$ & & & 207,396 \\
\hline $\begin{array}{c}\text { Cebidicola } \\
\text { armatus }\end{array}$ & Skin & & $\mathrm{X}$ & & & 207,396 \\
\hline $\begin{array}{l}\text { Cebidicola } \\
\text { semiarmatus }\end{array}$ & Skin & & $\mathrm{X}$ & & & 207,396 \\
\hline
\end{tabular}

For detailed information regarding the morphology and life cycle of these parasites, the reader is referred to standard pathology or parasitology texts [32, 290, $428,791,811]$.

\section{FLEA INFESTATION}

There is a relative paucity of information regarding the extent of flea infestation in nonhuman primates. The available reports concern fleas that, for the most part, are natural parasites of animals other than nonhuman primates (dogs, cats, and chickens). There is no suggestion about the importance of siphonapterids in nonhuman primates or of any potential role they may play in transmission of disease to humans [281].

Tunga penetrans (stick-tight, jigger, or chigoe flea) has been reported from Old World monkeys (guenons and baboons) [280, 281, 290, 791] and great apes (gorilla) [281, 814]. These parasites frequently invade the hard skin covering the ischial callosities where the female $T$. penetrans becomes firmly attached and penetrates into the epidermis that proliferates around the parasite. The implanted female fleas elicit severe irritation and pruritus, and secondary bacterial infections can occur particularly after removal of the parasite from the site of attachment $[280,281,290,352,791]$.

\section{Dermal Myiasis}

The larvae (bots) of several species of flies in the families Cuterebridae and Calliphoridae are reported to infect nonhuman primates [281, 290].

New World monkeys (howler monkeys) are reported to be a natural host for Cuterebra sp. larvae [281, 290, 792]. Infection with these parasites produces dermal cysts or swellings, containing a central pore, primarily in the cervical region. A chronic inflammatory reaction occurs around these sites and a seropurulent exudate containing the dark feces of the larva may exude through the pore. Healing of these lesions is usually rapid after emergence of the larva. Secondary bacterial infections can occur, and these may be more severe than the primary infection [290].

Diagnosis depends on demonstrating and identifying the typical larvae from the characteristic dermal cysts [290].

Although these flies affect humans in the geographical locations where they normally occur, captive nonhuman primates are not considered to be a direct human public health hazard [290]. 


\section{PEDICULOSIS}

\section{Mallophaga}

The mallophagans, or biting lice, are reported to be relatively rare on nonhuman primates and apparently are unimportant in regard on zoonoses [281]. Species of biting lice have been reported from prosimians (loris, indri, and mongoose lemur), New World monkeys (woolly spider monkeys, howler monkeys, and owl monkey), and Old World monkeys (colobus monkeys) [281, 814]. There is also a single report of infestation of rhesus monkeys with Eutrichophilus setosus, the porcupine-biting louse. These monkeys were housed in close proximity to a cage of porcupines, resulting in cross-infestation [277, 281]. There are no reports of Mallophaga infestations involving the great apes or humans.

\section{Anoplura}

Numerous species of anoplurans, or sucking lice, have been reported from a wide variety of nonhunan primates including prosimians (tree shrew, lemurs, and galagos), Old World monkeys (macaques, langurs, green monkeys, guenons, baboons, and colobus monkeys), New World monkeys (sakis, uakaris, howler monkeys, spider monkeys, marmosets, and tamarins), and great apes (gibbons, siamangs, chimpanzees, and gorilla) $[234,281,396,441,814,904]$. There has been at least one report of a black spider monkey (Ateles paniscus) being infested with the human head louse. The infection was thought to have been the result of contact with an infected person, indicating that the Anoplura can be shared by humans and the New World monkeys, but not the Old World monkeys [154, 281].

Fiennes [281] regards the sucking lice as interchangeable among humans, the great apes, and the New World monkeys, with the possible exception of the marmosets and tamarins. Old World monkeys are not affected by the species of Anoplura that infect humans, the great apes, and New World monkeys. There are no reports of transmission of rickettsial diseases by lice from the great apes or New World monkeys to humans, or vice versa, though in theory such transmission would seem possible [281].

\section{Arachnida}

The parasitic genera of ticks and mites described from nonhuman primates are listed in Tables 45.13 and 45.14, respectively. The most important members will be discussed in detail below.

As for the parasitic insecta, the reader is referred to standard pathology or parasitology texts for detailed information regarding the morphology and life cycle of these parasites [32, 290, 341, 428, 811].

\section{TICK INFESTATION}

According to Fiennes [281], the problem of ticks on captive monkeys is not important because when engorged, the ticks drop off the host, and, under the conditions of captivity, reinfection does not occur [281]. Species of ixodid ticks have been reported from numerous nonhuman primates including prosimians (bushbabies), New World monkeys (spider monkeys), and Old World monkeys (rhesus monkeys, cynomolgus monkeys, baboons, colobus monkeys, bonnet 
TABLE 45.13. Ticks described from nonhuman primates.

\begin{tabular}{|c|c|c|c|c|c|c|}
\hline $\begin{array}{c}\text { Parasite } \\
\text { genus-species }\end{array}$ & $\begin{array}{l}\text { Location in } \\
\text { host }\end{array}$ & $\begin{array}{c}\text { Pro- } \\
\text { simians }\end{array}$ & $\begin{array}{c}\text { New World } \\
\text { monkeys }\end{array}$ & $\begin{array}{l}\text { Old World } \\
\text { monkeys }\end{array}$ & $\begin{array}{l}\text { Great } \\
\text { apes }\end{array}$ & References \\
\hline Ixodids & & & & & & \\
\hline $\begin{array}{c}\text { Rhipicephalus } \\
\text { sanguineus }\end{array}$ & Skin & $\mathrm{X}$ & & $\mathrm{X}$ & & $\begin{array}{l}281,290,394 \\
395,609,862\end{array}$ \\
\hline $\begin{array}{l}\text { Rhipicephalus } \\
\text { appendiculatus }\end{array}$ & Skin & $\mathrm{X}$ & & $X$ & & $\begin{array}{l}290,394,395 \\
486,609\end{array}$ \\
\hline $\begin{array}{l}\text { Rhipicephalus } \\
\text { puchellus }\end{array}$ & Skin & & & $\mathrm{X}$ & & 488 \\
\hline $\begin{array}{l}\text { Rhipicephalus } \\
\text { haemaphysa- } \\
\text { loides }\end{array}$ & Skin & & & $\mathrm{X}$ & & 850 \\
\hline $\begin{array}{l}\text { Rhipicephalus } \\
\text { evertsi }\end{array}$ & Skin & & & $\mathrm{X}$ & & 395 \\
\hline $\begin{array}{l}\text { Rhipicephalus } \\
\text { pravus }\end{array}$ & Skin & & & $\mathrm{X}$ & & 395 \\
\hline $\begin{array}{l}\text { Rhipicephalus } \\
\text { simus }\end{array}$ & Skin & $\mathrm{X}$ & & $\mathrm{X}$ & & 395 \\
\hline $\begin{array}{l}\text { Dermacentor } \\
\text { auratus }\end{array}$ & Skin & & & $\mathrm{X}$ & & 850 \\
\hline $\begin{array}{l}\text { Ixodes } \\
\quad \text { ceylonensus }\end{array}$ & Skin & & & $\mathrm{X}$ & & 850 \\
\hline $\begin{array}{l}\text { Ixodes } \\
\quad \text { petauristae }\end{array}$ & Skin & & & $\mathrm{X}$ & & 850 \\
\hline $\begin{array}{l}\text { Ixodes } \\
\text { calvipalpus }\end{array}$ & Skin & & & $\mathrm{X}$ & & $281,395,814$ \\
\hline $\begin{array}{l}\text { Ixodes } \\
\quad \text { loricatus }\end{array}$ & Skin & & $\mathrm{X}$ & & & $\begin{array}{l}144,207,281 \\
814\end{array}$ \\
\hline $\begin{array}{l}\text { Ixodes } \\
\text { schillingeri }\end{array}$ & Skin & & & $\mathrm{X}$ & & $\begin{array}{l}281,290,394 \\
395,814\end{array}$ \\
\hline Ixodes rasus & Skin & & & $\mathrm{X}$ & & 395,488 \\
\hline Lxodes lemuris & Skin & $\mathrm{X}$ & & & & 395 \\
\hline Ixodes sp. & Skin & $\mathrm{X}$ & & & & 395 \\
\hline $\begin{array}{c}\text { Amblyomma } \\
\text { hebraeum }\end{array}$ & Skin & $\mathrm{X}$ & & $\mathrm{X}$ & & $\begin{array}{l}290,394,395 \\
578,609\end{array}$ \\
\hline $\begin{array}{c}\text { Amblyomma } \\
\text { variegatum }\end{array}$ & Skin & $\mathrm{x}$ & & & & 395 \\
\hline Amblyomma sp. & Skin & & & $\mathrm{X}$ & & $395,488,850$ \\
\hline $\begin{array}{l}\text { Boophilus } \\
\text { annulatus }\end{array}$ & Skin & & & $\mathrm{X}$ & & 281,814 \\
\hline $\begin{array}{l}\text { Hyalomma } \\
\text { truncatum }\end{array}$ & Skin & & & $\mathrm{X}$ & & 395 \\
\hline Hyalomma sp. & Skin & & & $\mathrm{X}$ & & 395 \\
\hline $\begin{array}{c}\text { Haemaphysalis } \\
\text { wellingtoni }\end{array}$ & Skin & & & $\mathrm{X}$ & & 850 \\
\hline $\begin{array}{l}\text { Haemaphysalis } \\
\text { aculeata }\end{array}$ & Skin & & & $\mathrm{x}$ & & 850 \\
\hline $\begin{array}{l}\text { Haemaphysalis } \\
\text { cuspidata }\end{array}$ & Skin & & & $\mathrm{X}$ & & 850 \\
\hline $\begin{array}{l}\text { Haemaphysalis } \\
\text { kyasanurensis }\end{array}$ & Skin & & & $\mathrm{X}$ & & 850 \\
\hline $\begin{array}{l}\text { Haemaphysalis } \\
\text { minuta }\end{array}$ & Skin & & & $\mathrm{X}$ & & 850 \\
\hline $\begin{array}{l}\text { Haemaphysalis } \\
\quad \text { leachii }\end{array}$ & Skin & $\mathrm{X}$ & & & & 395 \\
\hline $\begin{array}{l}\text { Haemaphysalis } \\
\text { lemuris }\end{array}$ & Skin & $\mathrm{X}$ & & & & $\begin{array}{l}395 \\
\quad \text { (Continued) }\end{array}$ \\
\hline
\end{tabular}


TABLE 45.13. (Continued).

\begin{tabular}{|c|c|c|c|c|c|c|}
\hline $\begin{array}{c}\text { Parasite } \\
\text { genus-species }\end{array}$ & $\begin{array}{l}\text { Location in } \\
\text { host }\end{array}$ & $\begin{array}{l}\text { Pro- } \\
\text { simians }\end{array}$ & $\begin{array}{l}\text { New World } \\
\text { monkeys }\end{array}$ & $\begin{array}{l}\text { Old World } \\
\text { monkeys }\end{array}$ & $\begin{array}{l}\text { Great } \\
\text { apes }\end{array}$ & References \\
\hline $\begin{array}{l}\text { Haemaphysalis } \\
\text { palmata }\end{array}$ & Skin & & & $\mathrm{X}$ & & $281,395,814$ \\
\hline $\begin{array}{l}\text { Haemaphysalis } \\
\text { spinigera }\end{array}$ & Skin & & & $\mathrm{X}$ & & $\begin{array}{l}290,849,850 \\
862\end{array}$ \\
\hline $\begin{array}{r}\text { Haemaphysalis } \\
\text { koningsbergi }\end{array}$ & Skin & $\mathrm{X}$ & & & & 11 \\
\hline $\begin{array}{l}\text { Haemaphysalis } \\
\text { hylobatis }\end{array}$ & Skin & & & & $\mathrm{X}$ & 11 \\
\hline $\begin{array}{l}\text { Haemaphysalis } \\
\text { bispinosa }\end{array}$ & Skin & & & $\mathrm{X}$ & & 637,850 \\
\hline $\begin{array}{l}\text { Haemaphysalis } \\
\text { turturis }\end{array}$ & Skin & & & $\mathrm{X}$ & & 850 \\
\hline $\begin{array}{l}\text { Haemaphysalis } \\
\quad \text { papuanakinneari }\end{array}$ & Skin & & & $\mathrm{X}$ & & 850 \\
\hline $\begin{array}{l}\text { Haemaphysalis } \\
\text { sp. }\end{array}$ & Skin & & & $\mathrm{X}$ & & 848 \\
\hline \multicolumn{7}{|l|}{ Argasids } \\
\hline $\begin{array}{l}\text { Ornithodorus } \\
\text { talaje }\end{array}$ & Skin & & & $\mathrm{X}$ & & $\begin{array}{l}144,281,290 \\
814\end{array}$ \\
\hline Argas reflexus & Skin & & & $\mathrm{X}$ & & 281,814 \\
\hline
\end{tabular}

macaques, langurs, and green monkeys) $[281,290,394,609,814,849,850]$. Argasid ticks have been infrequently reported from Old World monkeys (cynomolgus monkeys). In addition, the argasid tick, Argas reflexus, normally parasitic on pigeons and other avians, has been reported from an otherwise unidentified monkey [281, 814].

It appears that feral nonhuman primates are parasitized by ticks in most of the geographical areas in which they live and that they are infected by a variety of different species. The importance of ticks as parasites is their world-wide geographic distribution and their role as vectors of a wide variety of diseases, many of which are zoonotic. Since they can infect other animals and contaminate the premises, producing long-term difficulties in parasite control, procedures aimed at eliminating them from newly acquired animals are of primary importance $[281,791]$.

Most cases of tick infection are asymptomatic; however, heavy parasite loads can result in irritation, restlessness, weight loss, and anemia. Tick bites cause a local inflammatory reaction characterized by hyperemia, edema, and focal hemorrhage. Bite wounds may be involved with secondary bacterial infections [791].

Diagnosis is based on the signs and on the demonstration and identification of the specific species of tick on the host [290].

\section{Cutaneous Acariasis}

\section{Scabies (mange)}

The cause of this disease, Sarcoptes scabiei, the human itch mite, has been reported from Old World monkeys (cynomolgus monkeys and drills) [22, 290, 293, 305, 523, 891] and the great apes (gorillas, chimpanzees, orangutans, 
TABLE 45.14. Mites described from nonhuman primates.

\begin{tabular}{|c|c|c|c|c|c|c|}
\hline $\begin{array}{c}\text { Parasite } \\
\text { genus-species }\end{array}$ & $\begin{array}{l}\text { Location in } \\
\text { host }\end{array}$ & $\begin{array}{c}\text { Pro- } \\
\text { simians }\end{array}$ & $\begin{array}{l}\text { New World } \\
\text { monkeys }\end{array}$ & $\begin{array}{l}\text { Old World } \\
\text { monkeys }\end{array}$ & $\begin{array}{l}\text { Great } \\
\text { apes }\end{array}$ & References \\
\hline \multicolumn{7}{|l|}{$\overline{\text { Mesostigmates }}$} \\
\hline $\begin{array}{l}\text { Pneumonyssus } \\
\text { simicola }\end{array}$ & Lungs & & & $\mathrm{X}$ & $\mathrm{X}$ & $\begin{array}{l}1,22,24, \\
251,254,270, \\
286,290,301, \\
306,326,349, \\
393,405,413, \\
414,451,452, \\
456,457,522, \\
562,570,585, \\
629,725,821, \\
862,871,938\end{array}$ \\
\hline $\begin{array}{l}\text { Pneumonyssus } \\
\quad \text { duttoni }\end{array}$ & Bronchi, trachea & & & $\mathrm{X}$ & & $\begin{array}{l}145,251,253, \\
267,290,405, \\
413,630\end{array}$ \\
\hline $\begin{array}{r}\text { Pneumonyssus } \\
\text { santos-diasi }\end{array}$ & Lungs & & & $\mathrm{X}$ & & $\begin{array}{l}251,290,405 \\
413,485,488, \\
609,938\end{array}$ \\
\hline $\begin{array}{l}\text { Pneumonyssus } \\
\quad \text { longus }\end{array}$ & $\begin{array}{l}\text { Lungs, bronchi, } \\
\text { trachea }\end{array}$ & & & $X$ & $\mathrm{X}$ & $\begin{array}{l}251,253,290, \\
405,413\end{array}$ \\
\hline $\begin{array}{l}\text { Pneumonyssus } \\
\text { oudemansi }\end{array}$ & $\begin{array}{l}\text { Lungs, bronchi, } \\
\text { trachea }\end{array}$ & & & $X$ & $\mathrm{X}$ & $\begin{array}{l}56,249,251, \\
253,290,405, \\
413\end{array}$ \\
\hline $\begin{array}{l}\text { Pneumonyssus } \\
\text { africanus }\end{array}$ & Bronchi & & & $\mathrm{X}$ & & $\begin{array}{l}251,290,405, \\
413\end{array}$ \\
\hline $\begin{array}{l}\text { Pneumonyssus } \\
\quad \text { mossambicencis }\end{array}$ & Lungs & & & $\mathrm{X}$ & & $\begin{array}{l}251,290,405 \\
413,485,488, \\
578,609,938\end{array}$ \\
\hline $\begin{array}{l}\text { Pneumonyssus } \\
\text { congoensis }\end{array}$ & Trachea, lungs & & & $\mathrm{X}$ & & $\begin{array}{l}233,251,290 \\
405,413,488, \\
609\end{array}$ \\
\hline $\begin{array}{l}\text { Pneumonyssus } \\
\quad \text { rodhaini }\end{array}$ & $\begin{array}{l}\text { Lungs and nasal } \\
\text { fossae }\end{array}$ & & & $\mathrm{X}$ & & $246,405,413$ \\
\hline $\begin{array}{l}\text { Pneumonyssus } \\
\text { vitzthumi }\end{array}$ & Lung, bronchi & & & & $\mathrm{X}$ & $56,405,413$ \\
\hline $\begin{array}{l}\text { Pneumonyssus } \\
\text { vocalis }\end{array}$ & $\begin{array}{l}\text { Laryngeal } \\
\text { ventricles, vocal } \\
\text { pouch }\end{array}$ & & & $\mathrm{X}$ & & $573,577,578$ \\
\hline Pneumonyssus sp. & Lungs & & & $\mathrm{X}$ & & 405,413 \\
\hline $\begin{array}{l}\text { Rhinophaga } \\
\text { dinolti }\end{array}$ & $\begin{array}{l}\text { Nasal cavities, } \\
\text { lungs }\end{array}$ & & & $\mathrm{X}$ & & $\begin{array}{l}247,290,306, \\
405,413,653\end{array}$ \\
\hline $\begin{array}{l}\text { Rhinophaga } \\
\text { cercopitheci }\end{array}$ & $\begin{array}{l}\text { Lungs, frontal } \\
\text { sinuses }\end{array}$ & & & $\mathrm{X}$ & & $\begin{array}{l}247,268,290 \\
405,413,821\end{array}$ \\
\hline $\begin{array}{l}\text { Rhinophaga } \\
\text { papionis }\end{array}$ & $\begin{array}{l}\text { Lungs, nasal } \\
\text { fossae }\end{array}$ & & & $\mathrm{X}$ & & $\begin{array}{l}247,268,290 \\
405,413,488, \\
573,574,578, \\
609,821\end{array}$ \\
\hline $\begin{array}{r}\text { Rhinophaga } \\
\text { pongicola }\end{array}$ & $\begin{array}{l}\text { Maxillary } \\
\text { sinuses, nasal } \\
\text { fossae }\end{array}$ & & & & $\mathrm{X}$ & $250,405,413$ \\
\hline $\begin{array}{l}\text { Rhinophaga } \\
\text { elongata }\end{array}$ & Nasal mucosa & & & $\mathrm{X}$ & & $\begin{array}{l}488,573,574, \\
578\end{array}$ \\
\hline $\begin{array}{l}\text { Pneumonyssoides } \\
\text { stammeri }\end{array}$ & $\begin{array}{l}\text { Large bronchi- } \\
\text { ole, larynx, } \\
\text { nasal cavities, } \\
\text { sinuses }\end{array}$ & & $\mathrm{X}$ & & & $\begin{array}{r}254,290,327 \\
405,413,871 \\
\text { (Continued) }\end{array}$ \\
\hline
\end{tabular}


TARLE 45.14. (Continued).

\begin{tabular}{|c|c|c|c|c|c|c|}
\hline $\begin{array}{c}\text { Parasite } \\
\text { genus-species }\end{array}$ & $\begin{array}{l}\text { Location in } \\
\text { host }\end{array}$ & $\begin{array}{c}\text { Pro- } \\
\text { simians }\end{array}$ & $\begin{array}{c}\text { New World } \\
\text { monkeys }\end{array}$ & $\begin{array}{l}\text { Old World } \\
\text { monkeys }\end{array}$ & $\begin{array}{l}\text { Great } \\
\text { apes }\end{array}$ & References \\
\hline Rhinophagus sp. & $\begin{array}{l}\text { Mucosal and } \\
\text { submucosal } \\
\text { nasal tissues }\end{array}$ & & & $\mathrm{X}$ & & 450 \\
\hline \multicolumn{7}{|l|}{ Prostigmates } \\
\hline $\begin{array}{l}\text { Psorergates } \\
\quad \text { cercopitheci }\end{array}$ & Skin & & & $\mathrm{X}$ & & $\begin{array}{l}27,290,517 \\
710,793,938 \\
939\end{array}$ \\
\hline Psorergates sp. & Skin & & & $\mathrm{X}$ & & $513,517,521$ \\
\hline Demodex canis & Skin & & $\mathrm{X}$ & & $\mathrm{X}$ & 281,673 \\
\hline Demodex saimiri & Skin & & $\mathrm{X}$ & & & 520 \\
\hline Demodex sp. & Skin & & $X$ & & & $383,461,668$ \\
\hline \multicolumn{7}{|l|}{ Astigmates } \\
\hline Sarcoptes scabiei & Skin & & & $\mathrm{X}$ & $\mathrm{X}$ & $\begin{array}{l}22,281,290 \\
293,305,334, \\
523,675,706, \\
718,742,864 \\
890,891,931\end{array}$ \\
\hline Sarcoptes pitheci & Skin & & & $\mathrm{X}$ & & $281,673,742$ \\
\hline $\begin{array}{l}\text { Prosarcoptes } \\
\text { pitheci }\end{array}$ & Skin & & $\mathrm{X}$ & $\mathrm{X}$ & & $\begin{array}{l}257,260,265 \\
290,673\end{array}$ \\
\hline $\begin{array}{l}\text { Pithesaroptes } \\
\text { talapoini }\end{array}$ & Skin & & & $\mathrm{X}$ & & $260,265,290$ \\
\hline $\begin{array}{l}\text { Cosarcoptes } \\
\text { scanloni }\end{array}$ & Skin & & & $\mathrm{X}$ & & $265,290,804$ \\
\hline $\begin{array}{l}\text { Notoedres } \\
\quad \text { galagoensis }\end{array}$ & Skin & $\mathrm{X}$ & & & & $\begin{array}{l}257,259,265 \\
290\end{array}$ \\
\hline $\begin{array}{l}\text { Alouattalages } \\
\text { corbeti }\end{array}$ & Skin & & $\mathrm{X}$ & & & 263,290 \\
\hline $\begin{array}{c}\text { Fonsecalges } \\
\text { saimirii }\end{array}$ & Skin & & $\mathrm{X}$ & & & $\begin{array}{l}148,207,263 \\
289,290\end{array}$ \\
\hline $\begin{array}{l}\text { Paracoroptes } \\
\text { gordoni }\end{array}$ & Skin & & & $X$ & & $257,290,512$ \\
\hline $\begin{array}{l}\text { Pangorillages } \\
\text { pani }\end{array}$ & Skin & & & & $\mathrm{X}$ & 256,290 \\
\hline $\begin{array}{l}\text { Listrocarpus } \\
\text { cosgrovei }\end{array}$ & Skin & & $\mathrm{X}$ & & & $148,264,290$ \\
\hline $\begin{array}{l}\text { Listsrocarpus } \\
\text { hapalei }\end{array}$ & Skin & & $\mathrm{X}$ & & & 264,290 \\
\hline $\begin{array}{l}\text { Listrocarpus } \\
\text { saimirii }\end{array}$ & Skin & & $\mathrm{X}$ & & & 264,290 \\
\hline $\begin{array}{l}\text { Listrocarpus } \\
\text { lagothrix }\end{array}$ & Skin & & $\mathrm{X}$ & & & 264,290 \\
\hline $\begin{array}{c}\text { Rhyncoptes } \\
\text { anastosi }\end{array}$ & Skin & & $\mathrm{X}$ & & & 261,290 \\
\hline Rhyncoptes cebi & Skin & & $\mathrm{X}$ & & & 261,290 \\
\hline $\begin{array}{l}\text { Rhyncoptes } \\
\text { cercopitheci }\end{array}$ & Skin & & & $\mathrm{X}$ & & 261,290 \\
\hline $\begin{array}{r}\text { Saimirioptes } \\
\text { paradoxus }\end{array}$ & Skin & & $\mathrm{X}$ & & & 266,290 \\
\hline Audycoptes greeri & Hair follicles & & $\mathrm{X}$ & & & $\begin{array}{l}207,266,290, \\
515\end{array}$ \\
\hline $\begin{array}{c}\text { Audycoptes } \\
\text { lawrenci }\end{array}$ & Hair follicles & & $\mathrm{x}$ & & & $\begin{array}{l}207,266,290 \\
515\end{array}$ \\
\hline $\begin{array}{l}\text { Lemurnyssus } \\
\text { galagoensis }\end{array}$ & Nasal cavities & $\mathrm{X}$ & & & & 258,290 \\
\hline
\end{tabular}


TABLE 45.14. (Continued).

\begin{tabular}{|c|c|c|c|c|c|c|}
\hline $\begin{array}{c}\text { Parasite } \\
\text { genus-species }\end{array}$ & $\begin{array}{l}\text { Location in } \\
\text { host }\end{array}$ & $\begin{array}{l}\text { Pro- } \\
\text { simians }\end{array}$ & $\begin{array}{l}\text { New World } \\
\text { monkeys }\end{array}$ & $\begin{array}{l}\text { Old World } \\
\text { monkeys }\end{array}$ & $\begin{array}{l}\text { Great } \\
\text { apes }\end{array}$ & References \\
\hline $\begin{array}{l}\text { Mortelmansia } \\
\text { brevis }\end{array}$ & Nasal cavities & & $\mathrm{X}$ & & & $\begin{array}{l}148,207,252 \\
258,290\end{array}$ \\
\hline $\begin{array}{l}\text { Mortelmansia } \\
\quad \text { longis }\end{array}$ & Nasal cavities & & $\mathrm{X}$ & & & $\begin{array}{l}148,207,252 \\
258,290\end{array}$ \\
\hline $\begin{array}{l}\text { Mortelmansia } \\
\text { duboisi }\end{array}$ & Nasal cavities & & $\mathrm{X}$ & & & $\begin{array}{l}148,207,258 \\
290,492\end{array}$ \\
\hline $\begin{array}{l}\text { Dunnalges } \\
\text { lambrechti }\end{array}$ & Skin & & $\mathrm{X}$ & & & $\begin{array}{l}207,461,515 \\
516\end{array}$ \\
\hline $\begin{array}{l}\text { Rosalialges } \\
\quad \text { cruciformis }\end{array}$ & Skin & & $\mathrm{X}$ & & & $\begin{array}{l}207,461,515 \\
516\end{array}$ \\
\hline Prosarcoptes sp. & Skin & & & $\mathrm{X}$ & & 804 \\
\hline Pithesarcoptes $\mathrm{sp}$ & Skin & & & $\mathrm{X}$ & & 804 \\
\hline Kutzerocoptes sp. & Skin & & & $\mathrm{X}$ & & 517,804 \\
\hline $\begin{array}{l}\text { Trombiculidids } \\
\text { Trombicula sp. }\end{array}$ & Skin & & & $\mathrm{X}$ & & 281,848 \\
\hline
\end{tabular}

gibbons, and siamiangs) [281, 290, 334, 706, 718, 742, 864, 890, 891]. A closely related species, Prosarcoptes pitheci, has been reported in Old World monkeys (African green monkeys and baboons) and New World monkeys in captivity (cebus monkeys) $[257,260,265,290,673]$. Two sarcoptiform species, Dunnalges lambrechti and Rosalialges cruciformis, have been reported from New World monkeys (marmosets and owl monkeys) [461, 515]. There appear to be no reports of $S$. scabiei infection in prosimians [281].

Signs associated with $S$. scabiei infection in nonhuman primates include intense pruritus, anorexia, weakness, weight loss, tremors, and emaciation. Gross lesions include thickening and scaling of the skin and severe alopecia. The severe itching can result in self-mutilation, with secondary hemorrhage and suppurative bacterial dermatitis [290, 334, 523, 791, 864, 891]. Death of a chimpanzee has been ascribed to a severe $S$. scabiei infection [675].

Histopathologically, the infected skin is characterized by hyperkeratosis, parakeratosis, and crusting. The epidermis contains burrows in which many parasites and eggs are seen [290, 305, 334, 742, 791].

The tentative diagnosis of scabies is based on the signs and lesions and confirmed by demonstrating and identifying the parasites and/or eggs in deep skin scrapings [290, 791].

Sarcoptes scabiei infections in nonhuman primates are transmissible to humans by direct contact $[290,334,742,891,931]$. Thus, infected nonhuman primates, or those suspected of being infected, should be handled with caution by those responsible for their care and management [290].

\section{PULMONARY ACARIASIS}

The cause of this condition is any one of at least ten species of lung mites in the genus Pneumonyssus that have been reported from the lower respiratory tract of Old World monkeys (rhesus monkeys, cynomolgus monkeys, pig-tailed macaques, patas monkeys, Celebes black apes, mangabeys, baboons, numerous members of the genus Cercopithecus, colobus monkeys, langurs, and proboscis 
monkeys) and the great apes (chimpanzees, gorillas, and orangutans) [24, 56, $233,246,247,249,251,253,270,290,326,349,405,413,456,457,585,629$, $630,666,742,938]$. Also, there has been one species of lung mite in the genus Pneumonyssoides that has been reported from the lungs, larynx, nasal cavities, and sinuses in New World monkeys (woolly monkeys and howler monkeys) [254, $290,405,413,742,871]$.

The most commonly encountered member of this genus, Pneumonyssus simicola, is found in the lungs of essentially $100 \%$ of imported rhesus monkeys [286, $290,301,326,413,414,453,454,522,725]$. Also, this mite has been seen in the lungs of infant rhesus monkeys allowed to remain with their wild-caught parents after birth [519]. Reports of $P$. simicola infection in other macaque species are less frequent $[24,251,254,290,393,821]$. Despite the common occurrence in feral $M$. mulatta, $P$. simicola has not been seen in laboratory-born monkeys taken from their mothers at birth $[290,464]$. A high incidence of lung mite infection with species other than $P$. simicola has been reported from baboons [451, $452,823]$. The complete life cycle of this parasite is unknown [290, 301, 454].

The infection in the rhesus monkey is usually nonsymptomatic, and clinical signs are uncommon $[290,306,413,414,456,457,791]$. There have been reports of paroxysms of sneezing and coughing, but these may be the result of associated pulmonary disease $[290,375,413]$.

Gross lesions are randomly located throughout the pulmonary parenchyma and consist of varying-sized pale spots or yellowish-gray foci that are usually flat or slightly umbilicated on the surface and contain translucent areas. Those located near the surface of the lungs elevate the visceral pleura. The lesions can resemble tubercules but are soft to the touch rather than firm. Adjacent lesions may become confluent. Bullous emphysematous lesions and hemorrhagic lesions may be seen in some cases. Many animals have fine, stringlike fibrous adhesions between visceral and parietal pleural surfaces and between all of the lung lobes. Under the dissecting microscope, the lesions present as pale, white, jellylike masses that have a small opening or slit in the center. These so-called "mite houses" can contain from 1 to 20 mites. The majority of these are females, but sometimes eggs, larvae, and male mites are also present. A characteristic goldenbrown to black pigment permeates the lesions and surrounding pulmonary parenchyma $[290,326,341,349,413,414,456-458,503,791]$.

Histopathologically, lung mite lesions are characterized by a localized bronchiolitis, peribronchiolitis, focal lobular pneumonitis, alveolar collapse or consolidation, and sometimes bronchiolectasis. There is thickening of the bronchiolar wall, loss of the lining epithelium, hyperplasia of the bronchiolar smooth muscle, and formation of peribronchiolar lymphoid aggregations. A pleocellular inflammatory cell exudate consisting of neutrophils, eosinophils, lymphoplasmacytes, and macrophages infiltrates the affected bronchiolar wall. There is little or no tissue necrosis or giant cell formation $[290,326,341,349$, 413, 414, 456-458, 503, 791].

Macrophages, whose cytoplasm is laden with a golden-brown to blackish pigment and refractile crystals, are always present in and around the lesions and throughout the lung tissues. This pigment, which is not seen in the lungs of mitefree monkeys, does not contain carbon or melanin but is iron positive and birefringent under polarized light. The exact source of the pigment is not known, 
but it is felt that it probably results from the breakdown and excretion of the hosts' blood proteins by the mites $[290,326,341,349,413,414,456-458,503,639$, 791]. The immunological response to pulmonary acariasis has been reviewed by $\operatorname{Kim}[457]$.

Lung mite infection has been reported to be associated with pneumothorax [711] and pulmonary arteritis [510, 522,914] in the rhesus monkey. There is also a report that describes extensive pleuritis and pericarditis associated with ruptured lung mite lesions [455].

Even though several earlier reports ascribe fatalities to $P$. simicola infection, it probably results in death only under conditions of massive infections. Such cases of massive infections and resultant death have been reported in the rhesus monkey, proboscis monkey, "lion macaque," pig-tailed macaque, douc langurs, and chimpanzee $[14,34,298,344,357,405,457,818]$. The gross lesions and histopathology of lung mite infection in baboons and chimpanzees are similar to those described for rhesus monkeys [458, 570].

Diagnosis of lung mite infection in live monkeys is difficult. Thoracic $\mathrm{x}$-rays or hematologic studies are of little value $[290,414,791]$. There has been some success in demonstrating lung mite larvae in tracheobronchial washings, but a negative finding is not conclusive proof that infection does not exist. Gross lesions are rather characteristic but must be differentiated from tuberculosis. Tissue sections containing the mites and/or the characteristic pigment and crystals are diagnostic $[290,414,791]$. Lung mites can be found in the feces of infected nonhuman primates [667].

There is no evidence that $P$. simicola infects humans. Therefore, there is no public health significance associated with lung mite infections in nonhuman primates [290].

\section{NASAL ACARIASIS}

Five species of nasal mites of the genus Rhinophaga have been described from the upper skull and olfactory mucosa of Old World monkeys (rhesus monkeys, baboons, Cercopithecus sp.) and great apes (orangutan) [249, 268, 405, 413, $450,457,573,574,653]$. Rhinophaga papinois is found in the maxillary sinuses of the chacma baboon where it causes mucosal polyps [457, 547, 573]. In the lungs it causes pneumonitis and excessive mucus production. Rhinophaga elongata, also reported from the chacma baboon, is an extremely long mite that has been described in the apex of small mucosal nodules randomly distributed throughout the nasal cavity. The anterior third of the mite was embedded deeply in the nasal mucosa and in some cases in the adjacent bone. An inflammatory reaction and obstruction of the mucosal glands, which became greatly dilated, was associated with the presence of this mite [457, 573, 574]. Rhinophaga dinolti has been reported from the lungs and nasal cavities of the rhesus monkey. Lesions associated with the presence of this parasite in tissues have not been reported $[247,290,306,413,653]$. Rhinophaga cercopitheci has been reported from the lungs and frontal sinuses of several species of guenons (Cercopithecus ascanius, C. mitis). Lesions include pneumonitis and excessive mucus production [268, 290, 413, 821]. Rhinophaga pongicola has been reported from the maxillary sinuses and nasal fossae of an orangutan [250, 413]. 
TABLE 45.15. Pentastomids described from nonhuman primates.

\begin{tabular}{|c|c|c|c|c|c|c|}
\hline $\begin{array}{c}\text { Parasite } \\
\text { genus-species }\end{array}$ & $\begin{array}{l}\text { Location in } \\
\text { host }\end{array}$ & $\begin{array}{l}\text { Pro- } \\
\text { simians }\end{array}$ & $\begin{array}{l}\text { New World } \\
\text { monkeys }\end{array}$ & $\begin{array}{c}\text { Old World } \\
\text { monkeys }\end{array}$ & $\begin{array}{l}\text { Great } \\
\text { apes }\end{array}$ & References \\
\hline $\begin{array}{l}\text { Linguatula } \\
\text { serrata }\end{array}$ & $\begin{array}{l}\text { Mesenteric } \\
\text { lymphnodes, } \\
\text { viscera }\end{array}$ & & $\mathrm{X}$ & $\mathrm{X}$ & & $290,493,788$ \\
\hline $\begin{array}{c}\text { Porocephalus } \\
\text { clavatus }\end{array}$ & $\begin{array}{l}\text { Peritoneum, } \\
\text { viscera }\end{array}$ & & $\mathrm{X}$ & & & $\begin{array}{l}148,290,461 \\
623,689,750 \\
785,787,791 \\
800,815\end{array}$ \\
\hline $\begin{array}{l}\text { Porocephalus } \\
\text { subulifer }\end{array}$ & Viscera & $X$ & & $X$ & & $\begin{array}{l}255,290,788 \\
791\end{array}$ \\
\hline $\begin{array}{c}\text { Gigliolella } \\
\text { brumpti }\end{array}$ & Mesentery & $\mathrm{X}$ & & & & 104,290 \\
\hline $\begin{array}{l}\text { Armillifer } \\
\quad \text { armillatus }\end{array}$ & $\begin{array}{l}\text { Peritoneal } \\
\text { cavity }\end{array}$ & $X$ & $\mathrm{X}$ & $X$ & $\mathrm{X}$ & $\begin{array}{l}153,177,207, \\
255,280,290, \\
339,362,382, \\
393,461,486, \\
641,750,788, \\
791,815,902, \\
937\end{array}$ \\
\hline $\begin{array}{l}\text { Armillifer } \\
\quad \text { moniliformis }\end{array}$ & $\begin{array}{l}\text { Viscera, } \\
\text { peritoneal cavity }\end{array}$ & & & $X$ & & $\begin{array}{l}45,262,290 \\
788,791\end{array}$ \\
\hline $\begin{array}{l}\text { Porocephalus } \\
\text { crotali }\end{array}$ & Peritoneal cavity & & $\mathrm{X}$ & & & $177,207,815$ \\
\hline $\begin{array}{l}\text { Nephridiacanthus } \\
\text { sp. (juvenile) }\end{array}$ & Rectal wall & & & $\mathrm{X}$ & & 486,487 \\
\hline
\end{tabular}

\section{LARYNGEAL ACARIASIS}

A newly recognized mite, Pneumonyssus vocalis, has been reported from the mucosa of the laryngeal ventricles and vocal pouch of the chacma baboon where it elicits a mild local inflammatory response $[457,573,577]$.

\section{Pentastomids}

The parasitic pentastomid nymphs described from nonhuman primates are listed in Table 45.15. They are discussed in detail below.

\section{Pentastomiasis}

The parasites that cause this disease are considered to be highly aberrant arthropods [255, 290, 461, 785, 788]. Four genera have been described: Linguatula, which has a world-wide distribution; Porocephalus, found in both South America and Africa; Armillifer, which occurs in Africa, Asia, and Australia; and

TABLE 45.16. Anaplasmatids described from nonhuman primates.

\begin{tabular}{|c|c|c|c|c|c|c|}
\hline $\begin{array}{c}\text { Parasite } \\
\text { Genus-species }\end{array}$ & $\begin{array}{c}\text { Location in } \\
\text { Host }\end{array}$ & $\begin{array}{c}\text { Pro- } \\
\text { simians }\end{array}$ & $\begin{array}{l}\text { New World } \\
\text { Monkeys }\end{array}$ & $\begin{array}{l}\text { Old World } \\
\text { Monkeys }\end{array}$ & $\begin{array}{l}\text { Great } \\
\text { Apes }\end{array}$ & References \\
\hline $\begin{array}{l}\text { Hemobartonella } \\
\text { sp. }\end{array}$ & Erythrocyte & & $\mathrm{X}$ & & & 5 \\
\hline
\end{tabular}


Gigliolella, found on the Island of Madagascar. The nymph form occurs in nonhuman primates, which serve as intermediate hosts in the pentastome life cycle $[153,177,229,290,461,788,791,937]$. The adult forms of Linguatula are found in the nasal passages of dogs, other canids, domestic animals, and humans. Adults of the other two genera are found in the lungs and air sacs of various snakes $[290,461,788,791]$. Pentastomid nymphs have been reported in a wide variety of nonhuman primates, including prosimians, New and Old World monkeys, and great apes $[148,150,255,262,280,290,297,355,382,393,461,493,609$, $623,787,788,800,937]$.

Infection with this parasite usually is asymptomatic. Dead nymphs act as foreign bodies and invoke an intense inflammatory response in the host. Fatal peritonitis has been reported in overwhelming infections with penetration of the intestinal wall by nymphs. When one infection follows another of considerable duration, there may be a lymphocytic response as a result of presensitization by the initial infection $[150,255,290,297,461,786,787,800,902]$.

Diagnosis usually is based on an incidental finding at necropsy and hinges on the identification of the characteristic C-shaped nymph in the tissues [290]. Nymphs have been described in the lungs, liver, omentum, and serosa of the intestinal tract of nonhuman primates $[290,461,623,788,791]$ but may be found in almost any tissue, including the brain [297, 788].

Pentastomids have been reported in humans in tropical Africa and Asia, but the parasite in captive animals is of no public health significance [290, 692, 749]. Infection of humans can occur only through the ingestion of eggs passed in the feces or in the saliva of the definitive host [290].

Acknowledgments. The portion of this chapter concerning parasites of the alimentary tract and pancreas is reprinted from Toft JD II (1982) The pathoparasitology of the alimentary tract and pancreas of nonhuman primates: a review. Vet Pathol 19 (Supp 7): 44-92. Used by permission of Veterinary Pathology and The American College of Veterinary Pathologists.

\section{References}

1. Abbott DP, Majeed SK (1984) A survey of parasitic lesions in wild-caught laboratory-maintained primates (rhesus, cynomolgus, and baboon). Vet Pathol 21:198-207.

2. Aberle SD (1945) Primate malaria. Natl Acad Sci-Natl Res Council Publ, Washington, DC.

3. Abrambulo PV III, Abass JB, Walker JS (1974) Silvered leaf monkey (Presbytis cristatus). II. Gastrointestinal parasites and their treatment. Lab Anim Sci 24:299-306.

4. Adams L (1980) Research scores breakthrough in answer to marmoset disease. Zoo Sounds 16:11.

5. Adams MR, Lewis JC, Bullock BC (1984) Hemobartonellosis in squirrel monkeys (Saimiri sciureus) in a domestic breeding colony. Lab Anim Sci 34:82-85.

6. Albuquerque RDR, Baretto MP (1969) Estudos sobre reservatorios e vectores silvestres de Trypanosoma cruzi, XXXII-infeccão natural do simio Callicebus nigrifons (Spix, 1823) pelo T. cruzi. Rev Inst Med Trop S Paulo 11:115-122.

7. Allen AM (1957) Pulmonary hyatid in a rhesus monkey. Arch Path 64:148-151.

8. Allen AM (1960) Occurrence of the nematode, Anatrichosoma cutaneum, in the nasal mucosae of Macaca mulatta monkeys. Amer J Vet Res 21:389-392. 
9. Amberson JM, Schwarz E (1952) Ternidens deminatus Railliet and Henry, a nematode parasite of man and primates. Ann Trop Med Parasitol 46:227-237.

10. Amyx HL, Asher DM, Nash TE, Gibbs CJ Jr, Gajdusek DC (1978) Hepatic amebiasis in spider monkeys. Amer J Trop Med Hyg 27:888-891.

11. Anastos G (1950) The scutate ticks of Ixodidae of Indonesia. Entomol Amer 30 (New Ser): $1-144$.

12. Anderson DC, McClure HM (1982) Acute disseminated fatal toxoplasmosis in a squirrel monkey. JAVMA 181:1363-1366.

13. Anderson RC (1957) The life cycles of dipetalonematid nematodes (Filaroidea: Dipetalonematidae): the problem of their evolution. J Helminthol 31:203-224.

14. Anderson S (1974) Diseases in freshly imported Proboscis monkeys (Nasalis larvatus). 18th Internationalen Symposium über die Erakrankungen der Zootier Acad Verlag, Berlin, pp 307-312.

15. Anver MR, King NW, Hunt RD (1972) Congenital encephalitozoonosis in a squirrel monkey (Saimiri sciureus). Vet Pathol 9:475-480.

16. Artigas $P$ de $T$ (1933) Sobre o parasitismo do Saimiris sciureus por um Gongilonema (G. saimirisi, N. sp.) e as possibilidades de infestacão humana. Rev Soc Paulista Med Vet 3:83-91. Cited by Dunn FL The parasites of Saimiri in the context of Platyrrhine parasitism. In: Rosenblum LA, Cooper RW (eds) (1968) The squirrel monkey, Chapter 2. Academic, New York, pp 31-68.

17. Arya SN (1981) A new species of the genus Probstmayria Ransom, 1907 (Nematoda:Atractidae) from the rhesus macaque, Macaca mulatta. Primates 22:261-265.

18. Auerbach E (1953) A study of Balantidium coli Stein, 1863 in relation to cytology and behavior in culture. J Morphol 93:405-445.

19. Augustine DL (1939) Some observations on some ascarids from a chimpanzee (Pan troglodytes) with experimental studies on the susceptibility of monkeys (Macaca mulatta) to infection with human and pig ascaris. Amer J Hyg 30:29-33.

20. Ayala FM (1961) Hallazgo de Trypanosoma cruzi Chagas, 1909 en el mono Saimiri boliviensis de la Amazonia Peruana. Rev Bras Malar Doenc Trop 13:99-105.

21. Ayers KM, Jones SR (1978) The cardiovascular system. In: Benirschke K, Garner FM, Jones TC (eds) Pathology of laboratory animals, chapter 1, vol I. SpringerVerlag, New York, pp 2-69.

22. Baker EW, Evans TM, Gould DJ, Hull WB, Keegan HL (1956) A manual of parasitic mites of medical or economic importance. Tech Publ Natl Pest Control Assoc, New York.

23. Baker JR (1972) Protozoa of tissues and blood (other than the Haemosporina). In: Fiennes RNT-W (ed) Pathology of simian primates. Part II. Infections and parasitic diseases. S Karger, Basel, pp 29-56.

24. Banks N (1901) A new genus of endoparasitic acarians. Geneesk Tidschr NederlIndie 41:334-336.

25. Barretto MP, Siqueira AF, Ferriolli F, Carvelheiro JR (1966) Estudos sôbre reservatorios e vectores silvestres do Trypanosoma cruzi. Rev Inst Med Trop S Paulo 8:103-112.

26. Baskin GB, Wolf RH, Worth CL, Soike K, Gibson SV, Bieri JG (1983) Anemia, steatitis, and muscle necrosis in marmosets (Saguinus labiatus). Lab Anim Sci 33:74-80.

27. Baskin GB, Eberhard ML, Watson E, Fish R (1984) Diagnostic exercise: skin lesions in sooty mangabeys. Lab Anim Sci 34:602-603.

28. Baylis HA (1928) Some further parasitic worms from Sarawak. Ann Mag Nat Hist (10)1:606-608; cited by Inglis WG, Dunn FL (1963) The occurrence of Lemuricola (Nematoda:Oxyurinae) in Malaya: with the description of a new species. Z Parasitenk 23:354-359. 
29. Baylis HA (1929) A manual of helminthology, medical and veterinary. William Wood, New York. Cited by Ruch TC (1959) Diseases of laboratory primates. WB Saunders, Philadelphia.

30. Beach TD (1936) Experimental studies on human and primate species of strongyloides. V. The free-living phase of the life cycle. Amer J Hyg 23:243-277.

31. Beddard FE (1916) On two new species of cestodes belonging to the genera Linstowia and Cotugnia. Proc Zool Soc London, 87:695-706.

32. Belding DL (1965) Textbook of parasitology, 3rd ed. Appleton-Century-Crofts, New York.

33. Benirschke K (1979) Diagnostic exercise. Lab Anim Sci 29:33-34.

34. Benirschke K (1983) Occurrence of spontaneous diseases. In: Viral and immunological diseases in nonhuman primates. Alan R. Liss, New York, pp 17-30.

35. Benirschke K, Adams FD (1980) Gorilla diseases and causes of death. J Reprod Fertil Suppl 28:139-148.

36. Benirschke K, Low RJ (1970) Acute toxoplasmosis in woolly monkey (Lagothrix spp.). Comp Pathol Bull 2:3-4.

37. Benirschke K, Richart R (1960) Spontaneous acute toxoplasmosis in a marmoset monkey. Amer J Trop Med Hyg 9:269-273.

38. Benson RE, Fremming BD, Young RJ (1955) Care and management of chimpanzees at the Radiobiological Laboratory of the University of Texas and the United States Air Force, School Aviation Med. US Air Force Rept 55-48.

39. Berghe van den L, Peel E, Chardome M (1956) Trypanosoma irangiense, N. sp. parasite du singe de nuit Protodicticus [sic] potto ibeanus en Congo belge. Folia Scient Afr Cent 2:17

40. Berghe van den L, Chardome M, Peel E (1956) Etude d'un trypanosome du potto. Folia Scient Afr Cent 2:20.

41. Berghe van den L, Chardome M, Peel E (1963) Trypanosomes of the African lemurs, Perodicticus potto ibeanus and Galago demidovi thomasi. J Protozool 10:133-135.

42. Berghe van den L, Chardome M, Peel E (1964) The filarial parasites of the eastern gorilla in the Congo. J Helminthol 38:349-368.

43. Bergner JF Jr, Jachowski LA Jr (1968) The filarial parasite Macacanema formosana, from the Taiwan monkey and its development in various arthropods. Formosan Sci 22:1-68.

44. Bernstein JJ (1972) An epizootic of hydatid disease in captive apes. J Zoo Anim Med 3:16-20.

45. Bezubik B, Furmaga S (1960) The parasites in Macacus cynomolgus L. from Indonesia. Acta Parasit Pol 8:334-344.

46. Biagi FF, Beltran FH (1969) The challenge of amoebiasis: understanding pathogenic mechanisms. Int Rev Trop Med 3:219-239.

47. Bingham GA, Rabstein MM (1964) A study of the effectiveness of thiabendazole in the rhesus monkey. Lab Anim Care 14:357-365.

48. Bisseru B (1967) Diseases of man acquired from his pets. William Heinemann Medical Books, London.

49. Blackie WK (1932) A helminthological survey of southern Rhodesia. Mem London Sch Hyg Trop Med 9:91.

50. Blacklock B, Adler S (1922) A parasite resembling Plasmodium falciparum in a chimpanzee. Ann Trop Med Parasitol 16:99-106.

51. Blacklock B, Adler J (1922) The pathological effects produced by Strongyloides in a chimpanzee. Ann Trop Med Parasitol 16:283-290.

52. Blair WR (1904) Internal parasites in wild animals. Rep NY Zool Soc 8:129.

53. Blair WR (1912) Some common affections of the respiratory tract and digestive organs among primates. Zoologica 1:175-186, 1912. Cited by Ruch TC (1959) Diseases of laboratory primates. WB Saunders, Philadelphia. 
54. Blanchard $R$, Langeron $M$ (1913) Le paludisme des macaques (Plasmodium cynomolgi Mayer, 1907). Arch Parasitol 15:529-542.

55. Boever WJ, Britt $\mathrm{J}$ (1975) Hydatid disease in a mandrill baboon. JAVMA 167:619-621.

56. Böhm LK, Supperer R (1955) Zwei neue Lungenmilben aus Menschenaffen: Pneumonyssus oudemansi and Pneumonyssus vitzthumi (Ascarina, Halarachnidae). Oest Zool Z 6:11-29.

57. Bond VP, Bostic W, Hansen EL, Anderson AH (1946) Pathologic study of natural amebic infection in macaques. Amer J Trop Med 26:625-629.

58. Bonne C, Sandground JH (1939) On the production of gastric tumors, bordering on malignancy in Javanese monkeys through the agency of Nochtia nochti, a parasitic nematode. Amer J Cancer 37:173-185.

59. Bostrom RC, Slaughter LJ (1968) Trematode (Athesmia foxi) infection in two squirrel monkeys (Saimiri sciureus). Lab Anim Care 18:493-495.

60. Bostrom RE, Ferrell JF, Martin JE (1968) Simian amebiasis with lesions simulating human amebic dysentery. Abstr 51 19th Ann Meeting Amer Assoc Lab Anim Sci, Las Vegas.

61. Brack M, Niemitz C (1984) The parasites of wild-caught tarsiers (Tarsius bancanus). In: Niemitz C (ed) Biology of tarsiers. Gustav Fischer Verlag, New York, pp 77-84.

62. Brack M, Myers BJ, Kuntz RE (1973) Pathogenic properties of Molineus torulosus in capuchin monkeys, Cebus apella. Lab Anim Sci 23:360-365.

63. Brack M, Boncyk LH, Kalter SS (1974) Filaroides cebus (Gebauer, 1933)parasitism and respiratory infections in Cebus apella. J Med Primatol 3:164-173.

64. Brannon MJC, Faust EC (1949) Preparation and testing of a specific antigen for diagnosis of human strongyloidiasis. Amer J Trop Med Hyg 29:229-239.

65. Bray RS (1956) Studies on malaria in chimpanzees: I. The erythrocytic forms of Plasmodium reichenowi. J Parasitol 42:588-592.

66. Bray RS (1957) Studies on malaria in chimpanzees: III. Gametogony of Plasmodium reichenowi. Ann Soc Belge Med Trop 37:169-174.

67. Bray RS (1958) Studies on malaria in chimpanzees: V. The sporogonous cycle and mosquito transmission of Plasmodium vivax schwetzi. J Parasitol 44:46-51.

68. Bray RS (1959) Pre-erythrocytic stages of human malaria parasites: Plasmodium malariae. Brit Med J 2:679-680.

69. Bray RS (1960) Studies on malaria in chimpanzees. VIII. The experimental transmission and pre-erythrocytic phase of Plasmodium malariae, with a note on the host-range of the parasite. Amer J Trop Med Hyg 9:455-465.

70. Bray RS (1963) Malaria infections in primates and their importance to man. Ergeb Mikrobiol Immunitätsfor Exp Therap 36:168-213.

71. Bray RS (1963) The malaria parasites of anthropoid apes. J Parasitol 49:888-898.

72. Bray RS (1964) A check-list of the parasitic protozoa of west Africa with some notes on their classification. Bull Inst for Afr Noire 26:238-315.

73. Brede HD, Burger PJ (1977) Physaloptera caucasica (= abbreviata caucasica) in the South African baboon (Papio ursinus). Arbeiten aus dem Paul-Ehreich-Institut und dem Georg-Speyer-Hause 71:119-122.

74. Breznock AW, Pulley TL (1975) Anatrichosoma infection in two white-handed gibbons. JAVMA 167:631.

75. Britz WE Jr, Fineg J, Cook JE, Miksche ED (1961) Restraint and treatment of young chimpanzees. JAVMA 138:653-658.

76. Brooks BA (1963) More notes on Saimiri sciureus. Lab Primate Newslett 2:3-4.

77. Brown HW, Perna VP (1958) An overwhelming strongyloides infection. JAVMA 138:653-658.

78. Brown RJ (1969) Acanthocephalan myositis in a bushbaby. JAVMA 155:11411143. 
79. Brown RJ, Hinkle DK, Trevethan SP, Kupper JL, McKee AE (1972) Nosematosis in a squirrel monkey (Saimiri sciureus). J Med Primatol 2:114-123.

80. Brug SL (1934) Observations on monkey malaria. Riv Malar 13:121-142.

81. Brumpt E (1939) Les parasites du paludisme des chimpanzés. CR Sc Soc Biol 130:837-840.

82. Brumpt E, Joyeux C (1912) Sur un infusoire nouveau parasite du chimpanzé Troglodytella abrassarti, n. g, n. sp. Bull Soc Path Exot 5:499-503.

83. Brumpt E, Urbain A (1938) Epizootie vermineuse por acanthocéphales (Prosthenorchis) ayant sévi ala singerie due Museum de Paris. Ann Parasitol Hum Comp 16:289-300.

84. Bück G, Coudurier J, Quesnel JJ (1952) Sur deux nouveaux plasmodium observés chez un lémurien de Madagascar splénectomisé. Arch Institut Pasteur d'Algérie 30:240-243.

85. Buckley JJC (1931) On two new species of Enterobius from the monkey Lagothrix humboldti. J Helminthol 9:133-140.

86. Buckley JJC (1949) Cysticerci in liver and lung of ring-tailed lemur. Trans Roy Soc Trop Med Hyg 43:2.

87. Buckley JJC (1960) On Brugia gen. nov. for Wuchereria sp. of the "malayi" group, i.e. W. malayi (Brug, 1927), W. pahangi Buckley and Edeson, 1956, and W. pateri Buckley, Nelson and Heisch, 1958. Ann Trop Med Parasitol 54:75-77.

88. Bullock BC, Wolf RH, Clarkson TB (1967) Myocarditis associated with trypanosomiasis in a Cebus monkey (Cebus albifrons). JAVMA 151:920-922.

89. Burrows RB (1965) Microscopic diagnosis of the parasites of man VI. Yale University Press, New Haven.

90. Burrows RB (1972) Protozoa of the intestinal tract. In: Fiennes RNT-W (ed) Pathology of simian primates. Part II. Infectious and parasitic diseases. S Karger, Basel, pp 2-28.

91. Burton FD, Underwood C (1976) Intestinal helminths in Macaca sylvanus of Gibraltar. Can J Zool 54:1406-1407.

92. Butler TM (1973) The chimpanzee. In: Selected topics in laboratory animal medicine. Vol XVI: Aeromedical Review 1-73. USAF Sch Aerospace Med, Aerospace Med Div (AFSC), Brooks AFB, Texas, pp 1-81.

93. Bywater JEC, Mann KH (1960) Infestation of a monkey with the leech Dinobdella ferox. Vet Rec 72:955.

94. Caballero y CE, Peregrina DI (1938) Nemátodes de los mamiferos de México, I. An Inst Biol Univ Méx 18:169.

95. Cahill KM (1967) Thabendazole in massive strongyloidiasis. Amer J Trop Med Hyg 16:451-453.

96. Cameron TWM (1929) The species of Enterobius Leach, in primates. J Helminthol 7:161-182.

97. Casey HW, Ayers KM, Robinson FR (1978) The urinary system. In: Benirschke K, Garner FM, Jones TC (eds) Pathology of laboratory animals, chapter 3, vol I. Springer-Verlag, New York, pp 116-173.

98. Castellani A, Chalmers AJ (1910) Manual of tropical medicine. Ballière, Tindall and Cox, London.

99. Castellani A, Chalmers AJ (1913) Manual of tropical medicine, 2nd ed. Ballière, Tindall and Cox, London.

100. Chabuad AG (1952) Le genre Dipetalonema Diesing 1861: essai de classification. Ann Parasitol Hum Comp 27:250-285.

101. Chabaud AG (1955) Essai d'interprétation phylétique des cycles évolutifs chez les nématodes parasites de vertébres. Conclusions taxo-moniques. Ann Parasitol Hum Comp 30:83-126.

102. Chabaud AG, Anderson RC (1959) Nouvel essai de classification des filaires (superfamille des Filarioidea) II. Ann Parsitol Hum Comp 34:64-87. 
103. Chabaud AG, Choquet MT (1953) Nouveau essai de classification des filaires superfamille des Filarioidea. Ann Parasitol Hum Comp 28:172-192.

104. Chabaud AG, Choquet MT (1954) Nymphes du pentastome Gigliolella (n. gen.) brumpti (Giglioli, 1922) chez un Lemurien. Riv Parassitol 15:331-336.

105. Chabaud AG, Choquet MT (1955) Deux nématodes parasites de lémurien. Ann Parasitol Hum Comp 30:329.

106. Chabaud AG, Petter AJ (1958) Les nematodes parasites de lémuriens Malgaches. I. Mém Inst Sci Madagascar Ser A 12:139-158. Cited by Inglis WG, Dunn FL (1963) The occurrence of Lemuricola (Nematoda:Oxyurinae) in Malaya: with the description of a new species. Z Parasitenkunde 23:354-359.

107. Chabaud AG, Petter AJ (1959) Les nematodes parasites de lémuriens Malgaches. II. Un nouvel oxyure: Lemuricola contagiosus. Mém Inst Sci Madagascar Ser A 13:127-132. Cited by Inglis WG, Dunn FL (1963) The occurrence of Lemuricola (Nematoda:Oxyurinae) in Malaya: with the description of a new species. Z Parasitenkunde 23:354-359.

108. Chabaud AG, Petter AJ, Golvan YJ (1961) Les nematodes parasites de lémuriens Malgaches. III. Collection recolteé par M et Mme Francis Petter. Ann Parasit Hum Comp 36:113-126. Cited by Inglis WG, Dunn FL (1963) The occurrence of Lemuricola (Nematoda:Oxyurinae) in Malaya: with the description of a new species. $\mathrm{Z}$ Parasitenkunde 23:354-359.

109. Chagas C (1909) Neue Trypanosomen. Vorläufige Mitteilung Arch Schiffsu TropenHyg 13:120-122.

110. Chagas C (1924) Infection naturelle des singes due para (Chrysothrix sciureus L.) par Trypanosoma cruzi. CR Soc Biol 90:873-876.

111. Chalifoux LV, Hunt RD, García FG, Sehgal PK, Comiskey JR (1973) Filariasis in New World monkeys: histochemical differentiation of circulating microfilariae. Lab Anim Sci 23:211-220.

112. Chalmers DT, Murgatroyd LB, Wadsworth PF (1983) A survey of the pathology of marmosets (Callithrix jacchus) derived from a marmoset breeding unit. Lab Anim 17:270-279.

113. Chandler AC (1925) New records of Bertiella satyri (cestoda) in man and apes. Parasitol Cambr 17:421-425.

114. Chandler AC (1929) Some new genera and species of nematode worms, filarioidea, from animals dying in the Calcutta Zoological Garden. Proc US Nat Mus 75:1.

115. Chandler AC (1953) An outbreak of Prosthenorchis (Acanthocephala) infection in primates in the Houston Zoological Garden, and a report of this parasite in Nasua narica in Mexico. J Parasitol 39:226.

116. Chandler AC, Read CP (1961) Introduction to parasitology, with special reference to the parasites of man, 10th ed. John Wiley, New York.

117. Chandler FW, McClure HM, Campbell WG Jr, Watts JC (1976) Pulmonary pneumocystosis in nonhuman primates. Arch Pathol Lab Med 100:163-167.

118. Chang J, McClure HM (1975) Disseminated oesophagostomiasis in the rhesus monkey. JAVMA 167:628-630.

119. Chang J, Kornegay RW, Wagner JL, Mikat EM, Hackel DB (1980) Toxoplasmosis in a sifaka. In: Montali RJ, Migaki G (eds) The comparative pathology of zoo animals. Smithsonian Institution Press, Washington, DC, pp 347-352.

120. Chang PCH, Graham GL (1957) Parasitism, parthenogenesis and polyploidy: the life cycle of Strongyloides papillosus. J Parasitol Suppl 43:13.

121. Chapman WL, Crowell WA, Isaac W (1973) Spontaneous lesions seen at necropsy in 7 owl monkeys (Aotus trivirgatus). Lab Anim Sci 23:434-442.

122. Chardome M, Peel E (1949) La répartition des filaires dans la region de Coquilhatville et la transmission de Dipetalonema streptocerca par Culicoides grahami. Ann Soc Belge Med Trop 29:99-119.

123. Chase RE, Degaris CF (1938) Anomalies of venae cavae superiores in an orang. Amer J Phys Anthro 24:61-65. 
124. Cheever AW, Kirschstein RL, Reardon LV (1970) Schistosoma mansoni infection of presumed natural origin in Cercopithecus monkeys from Tanzania and Ethiopia. Bull World Health Org 42:486-490.

125. Cheng TC (1964) The biology of animal parasites. WB Saunders, Philadelphia.

126. Chin W, Contacos PG, Coatney GR, Kimball HR (1965) A naturally acquired quotidian-type malaria in man transferable to monkeys. Science 149:865.

127. Chitwood M (1970) Comparative relationships of some parasites of man and Old and New World subhuman primates. Lab Anim Care 20:389-394.

128. Chitwood M, Lichtenfels JR (1972) Identification of parasitic metazoa in tissue sections. Exper Parasitol 32:407-519.

129. Chitwood MB, Smith WN (1958) A redescription of Anatrichosoma cynomolgi Smith and Chitwood 1954. Proc Helminthol Soc, Washington, DC 25:112-117.

130. Christeller E (1922) Über die Balantidienruhr bei den Schimpansen des Berliner Zoologischen Gartens. Virchows Arch 238:396-422. Cited by Ruch TC (1959) Diseases of laboratory primates. WB Saunders, Philadelphia.

131. Christensen LT (1964) Chimp and owners share worm infestation. Vet Med 59:801-803.

132. Cicmanec JL, Neva FA, McClure HM, Loeb WF (1974) Accidental infection of laboratory-reared Macaca mulatta with Trypanosoma cruzi. Lab Anim Sci 24:783-787.

133. Clark JD (1969) Coenurosis in a Gelada baboon (Theropithecus gelada). JAVMA 155:1258-1263.

134. Clarkson TB, Bullock BC, Lehner NDM, Manning PJ (1970) Diseases affecting the usefulness of nonhuman primates for nutrition research. In: Harris RS (ed) Feeding and nutrition of nonhuman primates. Academic, New York, pp 233-250.

135. Coatney GR, Collins WE, Warren McW, Contacos PG (1971) The primate malarias. US Govt Printing Office, Washington, DC, pp 1-366.

136. Coatney GR, Elbel RE, Kocharantana $P(1960)$ Some blood parasites found in birds and mammals from Loei Province, Thailand. J Parasitol 46:701-702.

137. Cockburn TA (1948) Balantidium infection associated with diarrhoea in primates. Trans Roy Soc Trop Med Hyg 42:291-293.

138. Cockrell BY, Valerio MG, Garner FM (1974) Cryptosporidiosis in the intestines of rhesus monkeys (Macaca mulatta). Lab Anim Sci 24:881-887.

139. Colley FC, Mullin SW (1972) Eimeria pachylepyron sp. n. (Protozoa:Eimeriidae) from the slow loris in Malaysia. J Parasitol 58:110-111.

140. Collins WE (1974) Primate malarias. Adv Vet Sci Comp Med 18:1-23.

141. Collins WE, Contacos PG, Garnham PCC, Warren MSW, Skinner JC (1972) Plasmodium hylobati: a malaria parasite of the gibbon. J Parasitol 58:123-128.

142. Conrad HD, Wong MM (1969) Anatrichosoma sp. in Old World non-human primates. Program and Abstracts. No 52, p 41. 44th Ann Meeting Amer Soc Parasitologists, 3-7 Nov, Washington, DC. Cited by Orihel TC (1970) Anatrichosomiasis in African monkeys. J Parasitol 56:982-985.

143. Conran PB (1967) Monkey malaria. Abstr 38, 18th Ann Meeting Amer Assoc Lab Animal Sci, Washington, DC.

144. Cooley RA, Kohls GM (1944) The Argasidae of North America, Central America and Cuba. Amer Midl Natur Monogr 1.

145. Cooreman J (1946) Observations sur Pneumonyssus duttoni Newstead et Todd. Acarien parasite de la trachée de Cercopithecus ascanius Audebert au Congo belge. Rev Zool Bot Afr 39:331-335.

146. Copeland BE, Kimber J (1968) Nuclear size in diagnosis of Entamoeba histolytica on stained smears. Amer J Clin Path 38:664-668.

147. Cosgrove GE (1966) The trematodes of laboratory primates. Lab Anim Care 16:23-39.

148. Cosgrove GE, Nelson B, Gengozian N (1968) Helminth parasites of the tamarin, Saguinus fuscicollis. Lab Anim Care 18:654-656. 
149. Cosgrove GE, Humanson G, Lushbaugh CC (1970) Trichospirura leptostoma, a nematode of the pancreatic ducts of marmosets (Saguinus spp.). JAVMA 157: 696-698.

150. Cosgrove GE, Nelson BM, Self JT (1970) The pathology of pentastomid infection in primates. Lab Anim Care 20:354-360.

151. Cram EB (1928) A species of the genus Bertiella in man and chimpanzees in Cuba. Amer J Trop Med Hyg 8:339-344.

152. Crosby WM, Ivey MH, Shaffer WL, Holmes DD (1968) Echinococcus cysts in the Savannah baboon. Lab Anim Care 18:395-397.

153. Cruz AA da, De Sousa L (1959) Armillifer armillatus in chimpanzee (Pan satyrus verus). Rev Cien Vet 54:21-24.

154. Cummings BF (1916) Studies on the Anoplura and Mallophaga being a report upon a collection from the mammals and birds in the Society's gardens. Proc Zool Soc London 1:253-295.

155. Cummins LB, Keeling ME, McClure HM (1973) Preventive medicine in anthropoids: parasite control. Lab Anim Sci 23:819-822.

156. Cunha A da, Muniz J (1929) Nota sobre os parasitas intestinaes do Macacus rhesus com a descripcão de una nova especie de Octomitus. Mem Inst Oswaldo Cruz Suppl 5:34-35.

157. Curasson GCM (1929) Troglodytella abrassarti infusoire pathogène du chimpanzé. Ann Parasitol Hum Comp 7:465-468.

158. Das KM (1965) Discussion. In: Ribelin WE, McCoy JR (eds) Pathology of laboratory animals. Charles C Thomas, Springfield, IL, pp 363-364.

159. Deane LM (1962) Infeccão natural sagüi Callithrix jacchus por tripanosoma do tipo cruzi. Rev Inst Med Trop S Paulo 4:225-229.

160. Deane LM (1964) Animal reservoirs of Trypanosoma cruzi in Brazil. Rev Bras Malar Doenc Trop 16:27-48.

161. Deane LM (1967) Tripanosomídeos de mamiferos de regiao Amazônico. Rev Inst Med Trop S Paulo 9:143-148.

162. Deane LM, Damasceno RG (1961) Tripanosomídeos de mamiferos de região Amazônico. II. Tripanosomas de macacos de zona de Salgado, estado do Pará. Rev Inst Med Trop S Paulo 3:61-70.

163. Deane LM, Martins R (1952) Sobre um tripanosoma encontrado em macaco da Amazonia e que evolui em triatomineos. Rev Bras Malar Doenc Trop 4:47-61.

164. Deane LM, Deane MP, Neto JF (1966) Studies on transmission of simian malaria and on a natural infection of man with Plasmodium simium in Brazil. Bull World Health Org 35:805-808.

165. Deane LM, Ferreira N, Sitonio JG (1968) Novo hospedeiro natural do Plasmodium simium e do Plasmodium brasilianum: o mono, Brachyteles arachnoides. Rev Inst Med Trop S Paulo 10:287-288.

166. Deane LM, Batista D, Ferreria Neto JA, DeSouza H (1970) Tripanosomídeos de mamiferos da região Amazônico. V. Trypanosoma lambrechti Marinkelle, 1968, em macacos de Estado do Amazonas, Brasil. Rev Inst Med Trop S Paulo 12:1-7.

167. Deinhardt JB, Devine J, Passovoy M, Pohlman R, Deinhardt F (1967) Marmosets as laboratory animals. I. Care of marmosets in the laboratory. Pathology and outline of statistical evaluation of data. Lab Anim Care 17:11-29.

168. Deinhardt F, Holmes AW, Devine J, Deinhardt Jean (1969) Marmosets as laboratory animals. IV. The microbiology of laboratory kept marmosets. Lab Anim Care $17: 48-70$.

169. De Korte WE (1905) On the presence of sarcosporidium in the thigh muscles of Macaca rhesus. J Hyg 5:451-453.

170. DePaoli A (1965) Schistosoma haematobium in the chimpanzee-a natural infection. Amer J Trop Med Hyg 14:561-565. 
171. DePaoli A, Johnsen DO (1978) Fatal strongyloidiasis in gibbons (Hylobates lar). Vet Pathol 15:31-39.

172. Deschiens REA (1927) Sur les protozoaires intestinaux des singes. Bull Soc Path Exot 20:19-23. Cited by Miller MJ, Bray RS (1966) Entamoeba histolytica infections in the chimpanzee (Pan satyrus). J Parasitol 52:386-388.

173. Deschiens REA, Limousin H, Troisic J (1927) Eléments preséntant les caractéres d'un protozoaire sanguicole observés chez le chimpanzé. Bull Soc Path Exot 20:597-600.

174. Desowitz RS (1968) Hepatocystis sp. from a gibbon. Trans Roy Soc Trop Med Hyg 62:4.

175. Desowitz RS (1970) Observations on hepatocystis of white-cheeked gibbon (Hylobates concolor). J Parasitol 56:444-446.

176. Desportes C (1945) Sur Strongyloides stercoralis (Bavay 1876) et sur les strongyloides des primates. Ann Parasitol Hum Comp 20:160-190.

177. Desportes C, Roth $\mathbf{P}(1943)$ Helminthes rècoltés au cours d'autopsies pratiquées sur différents mammiferes morts á la ménagerie due Muséum de Paris. Bull Musée Hist Nat Paris 15:108-114. Cited by Dunn FL (1968) The parasites of Saimiri in the context of Platyrrhine parasitism. In: Rosenblum LA, Cooper RW (eds) The squirrel monkey. Academic, New York, pp 31-68.

178. Dickson J, Fry J, Fairfax R, Spence T (1983) Epidemic toxoplasmosis in captive squirrel monkeys (Saimiri sciureus). Vet Rec 12:302.

179. Dissanaike AS (1958) On hydatid infection in a Ceylon toque monkey Macaca sinica. Ceylon Vet 7:33-35.

180. Dissanaike AS, Nelson P, Garnham PCC (1965) Two new malaria parasites, Plasmodium cynomolgi ceylonensis subsp. nov. and Plasmodium fragile sp. nov., from monkeys in Ceylon. Ceylon J Med Sci 14:1-9.

181. Dissanaike AS, Nelson P, Garnham PCC (1965) Plasmodium simiovale sp. nov. A new simian malaria parasite from Ceylon. Ceylon J Med Sci 14:27-32.

182. Dobell C (1931) Researches on the intestinal protozoa of monkeys and man. IV. An experimental study of the histolytica-like species of Entamoeba living naturally in macaques. Parasitology 23:1-72.

183. Döbereiner J (1955) Toxoplasmose espontânea em macaco. Veterinaria 9:44-55.

184. Dodd K, Murphy E (1970) Dipetalonema gracile in a capuchin monkey (Cebus capucinus). Vet Rec 87:538-539.

185. Dollifus RP, Chabaud, AG (1955) Cing espéces de nématodes chez un atéle mort á la ménagerie du muséum. Arch Musée Natl Hist Nat 3:27-40. Cited by Dunn FL (1968) The parasites of Saimiri in the context of Platyrrhine parasitism. In: Rosenblum LA, Cooper RW (eds) The squirrel monkey. Academic, New York, pp 31-68.

186. Donovan JC, Stokes WS, Montrey RD, Rozmiarek H (1983) Hematologic characterization of naturally occurring malaria (Plasmodium inui) in cynomolgus monkeys (Macaca fascicularis). Lab Anim Sci 33:86-89.

187. Dougherty EC (1943) The genus Filaroides van Beneden, 1858, and its relatives. Preliminary note. Proc Helminthol Soc Washington, DC 10:69-74.

188. Dougherty EC (1952) A note on the genus Metathelazia Skinker, 1931 (Nematoda: Metastrongylidae). Proc Helminthol Soc Washington, DC 19:55-63.

189. Dubey JP (1973) Feline toxoplasmosis and coccidiosis: a survey of domiciled and stray cats. JAVMA 162:873-877.

190. Dubey JP (1976) A review of sarcocystis of domestic animals and of other coccidia of cats and dogs. JAVMA 169:1061-1078.

191. Dubey JP, Swan GV, Frenkel JK (1972) A simplified method for isolation of Toxoplasma gondii from the feces of cats. J Parasitol 58:1005-1006.

192. Dubin IN, Wilcox A (1947) Sarcocyst is in Macaca mulatta. J Parasitol 33:151-153.

193. Dubois G (1966) Un néodiplostome (Trematoda: Diplostomatidae) chez le tamarin Leontocebus nigricollis (Spix). Rev Suisse Zool 73:37-42. 
194. Duke BOL (1954) The transmission of loiasis in the forest-fringe area of the British Cameroons. Ann Trop Med Parasitol 48:349-355.

195. Duke BOL (1954) The uptake of the microfilariae of Acanthocheilonema streptocerca by Culicoides grahamii, and their subsequent development. Ann Trop Med Parasitol 48:416-420.

196. Duke BOL (1955) The development of Loa in flies of the genus Chrysops and the probable significance of the different species in the transmission of loiasis. Trans Roy Soc Trop Med Hyg 49:115-121.

197. Duke BOL (1956) The intake of the microfilariae of Acanthocheilonema perstans by Culicoides grahamii and $C$. inornatipennis, and their subsequent development. Ann Trop Med Parasitol 50:32-38.

198. Duke BOL (1960) Studies on loiasis in monkeys. III. The pathology of the spleen in drills (Mandrillus leucophaeus) infected with Loa. Ann Trop Med Parasitol 54:141-146.

199. Duke BOL, Wijers DJB (1958) Studies on loiasis in monkeys. I. The relationship between human and simian Loa in the rain-forest zone of the British Cameroons. Ann Trop Med Parasitol 52:158-175.

200. Dumas J (1953) Les animaux de laboratoire Paris (Ed. Médicales Flammarion, Paris). Cited by Ruch TC (1959) Diseases of laboratory primates. WB Saunders, Philadelphia.

201. Dunn FL (1961) Molineus vexillarius sp. n. (Nematoda:Trichostrongylidae) from a Peruvian primate Tamarinus nigricollis (Spix, 1823). J Parasitol 47:953-956.

202. Dunn FL (1962) Raillietina (R.) trinitatae (Cameron and Reesal, 1951), Baer and Sandars, 1956 (Cestoda) from a Peruvian primate. Proc Helminthol Soc Washington, DC 29:148-152.

203. Dunn FL (1963) A new trichostrongylid nematode from an oriental primate. Proc Helminthol Soc Washington, DC 30:161-165.

204. Dunn FL (1963) Acanthocephalans and cestodes of South American monkeys and marmosets. J Parasitol 49:717-722.

205. Dunn FL (1964) Blood parasites of Southeast Asian primitive primates. J Parasitol 50:214-216.

206. Dunn FL (1965) On the antiquity of malaria in the Western Hemisphere. Hum Biol 37:385-393.

207. Dunn FL (1968) The parasites of Saimiri in the context of Platyrrhine parasitism. In: Rosenblum LA, Cooper RW (eds) The squirrel monkey. Academic, New York, pp 31-68.

208. Dunn FL (1970) Natural infection in primates: helminths and problems in primate phylogeny, ecology, and behavior. Lab Anim Care 20:383-388.

209. Dunn FL, Greer WE (1962) Nematodes resembling Ascaris lumbricoides L., 1758, from a Malayan gibbon, Hylobates agilis $\mathrm{F}$. Cuvier, 1821. J Parasitol 48:150.

210. Dunn FL, Lambrecht FL (1963) On some filarial parasites of South American primates with a description of Tetrapetalonema tamarinae $\mathrm{n}$. $\mathrm{sp}$. from the Peruvian tamarin marmoset, Tamarinus nigricollis (Spix, 1823). J Helminthol 37:261-286.

211. Dunn FL, Lambrecht FL (1963) The hosts of Plasmodium brasilianum Gonder and von Berenberg-Gossler, 1908. J Parasitol 49:316-319.

212. Dunn FL, Lambrecht FL, du Plessis R (1963) Trypanosomes of South American monkeys and marmosets. Amer J Trop Med Hyg 12:524-534.

213. Dunn FL, Lim BL, Yap LF (1968) Endoparasites patterns in mammals of the Malayan rain forest. Ecology 49:1179-1184.

214. Durden LA, DeBruyn EJ (1984) Louse infestations of tree shrews (Tupaia glis). Lab Anim Sci 34:188-190.

215. Durette-Desset M-C, Palmieri JR, Purnomo, Cassone J (1981) Two new species of Tupaiostrongylus Dunn, 1963 (Nematoda: Molineidae) from a tree shrew (Tupaia tana) of Indonesia. System Parasitol 3:237-242. 
216. Durette-Desset MD, Chabaud AG (1975) Sur trois nematodes trichostrongylides parasites de Tupaiidae. Ann Parasitol 50:173-185.

217. Duszynski DW, File SK (1974) Structure of oocyst and excystation of sporozoites of Isospora endocallimici $\mathrm{n}$. sp. from marmoset Callimico goeldii. Trans Amer Micr Soc 93:403-408.

218. Dutton JE, Todd JL, Tobey EN (1906) Concerning certain parasitic protozoa observed in Africa. Mem Lpool Sch Trop Med 21:87-97.

219. Eastin CE, Roeckel I (1968) Trypanosoma cruzi complicating Prosthenorchis infestation in the squirrel monkey (Saimiri sciureus). Abst 52 19th Ann Meeting Amer Assoc Lab Animal Sci, Las Vegas.

220. Eberhard ML (1981) Intestinal parasitism in an outdoor breeding colony of Macaca mulatta. Lab Anim Sci 31:282-285.

221. Edeson JFB, Wharton RH, Laing ABG (1960) A preliminary account of the transmission, maintenance and laboratory vectors of Brugia pahangi. Trans Roy Soc Trop Med Hyg 54:439-449.

222. Edsall G, Gaines S, Landy M, Tigertt WD, Sprinz H, Trapani RJ, Mandel AD, Benenson AS (1960) Studies on infection and immunity in experimental typhoid fever. I. Typhoid fever in chimpanzees orally infected with Salmonella typhosa. J Exp Med 112:143-166.

223. Eichhorn A, Gallagher B (1916) Spontaneous amoebic dysentery in monkeys. J Inf Dis 19:395-407.

224. Eisenbrandt DL, Floering DA, David TD, McKee AE (1978) Scanning electron microscopy of a cryofractured hydatid cyst. In: Scanning electron microscopy, vol II. SEM, AMF O'Hare, IL, pp 229-233.

225. Eisenstein R, Innes JRM (1956) Sarcosporidiosis in man and animals. Vet Rev Annot 2:61-78.

226. Elek SR, Finkelstein LE (1939) Multiceps serialis infestation in a baboon. Report of a case exhibiting multiple connective tissue masses. Zoologica: Sci Contrib NY Zool Soc 24:323-328.

227. Else JG, Satzger M, Sturrock RF (1982) Natural infections of Schistosoma mansoni and $S$. haematobium in Cercopithecus monkeys in Kenya. Ann Trop Med Parasitol 76:111-112.

228. Essbach H (1949) Strongyloidose beim Schimpansen. Beitr Path Anat 110:319345. Cited by Ruch TC (1959) Diseases of laboratory primates. WB Saunders, Philadelphia.

229. Esslinger JH (1962) Hepatic lesions in rats experimentally infected with Porocephalus crotali (Pentastomida). J Parasitol 48:631-638.

230. Esslinger JH (1966) Dipetalonema obtusa (McCoy, 1936) comb. n. (Filarioidea:Onchocercidae) in Colombian primates, with a description of the adult. J Parasitol 52:498-502.

231. Esslinger JH, Gardiner CH (1974) Dipetalonema barbascalensis sp. n. (Nematoda: Filarioidea) from the owl monkey, Aotus trivirgatus, with a consideration of the status of Parlitomosa zakii Nagaty, 1935. J Parasitol 60:1001-1005.

232. Evans LB (1978) Fatal parasitism among free living bushbabies. J S Afr Vet Assoc 49:67-69.

233. Ewing HE (1929) Notes on the lung mites of primates (Acarina, Dermanyssidae), including the description of a new species. Proc Ent Soc Wash 31:126-130.

234. Ewing HE (1932) A new sucking louse from the chimpanzee. Proc Biol Soc Washington 45:117-118.

235. Ewing SA, Helland DR, Anthony HD, Leipold HW (1968) Occurrence of Athesmia sp. in the cinnamon ringtail monkey Cebus albifrons. Lab Anim Care 18:488-492.

236. Eyles DE (1963) The species of simian malaria: taxonomy, morphology, life cycle, and geographical distribution of the monkey species. J Parasitol 49:866-887.

237. Eyles DE, Warren McW (1962) Plasmodium inui in Sulawesi. J Parasitol 48:739. 
238. Eyles DE, Warren McW (1963) Hepatocystis from Macaca irus in Java. J Parasitol 49:891.

239. Eyles DE, Coatney GR, Getz ME (1960) Vivax-type malaria parasite of macaques transmissible to man. Science 131:1812-1813.

240. Eyles DE, Fong YL, Warren McW, Guinn E, Sandosham AA, Wharton RH (1962) Plasmodium coatneyi, a new species of primate malaria from Malaya. Amer J Trop Med Hyg 11:597-604.

241. Eyles DE, Laing ABG, Dobrovolny CG (1962) The malaria parasites of the pigtailed macaque Macaca nemestrina nemestrina (Linnaeus), in Malaya. Ind J Malar 16:285-298.

242. Eyles DE, Laing ABG, Fong YL (1962) Plasmodium fieldi sp. nov., a new species of malaria parasite from the pig-tailed macaque in Malaya. Ann Trop Med Parasitol 56:242-247.

243. Eyles DE, Warren McW, Fong YL, Sandosham AA, Dunn FL (1962) A malaria parasite of Malayan gibbons. Med J Malaya 17:86.

244. Eyles DE, Fong YL, Dunn FL, Guinn E, Warren McW, Sandosham AA (1964) Plasmodium youngi $\mathrm{n}$. sp., a malaria parasite of the Malayan gibbon, Hylobates lar lar. Amer J Trop Med Hyg 13:248-255.

245. Ezzat MAE, Gaafar SM (1951) Tetrathyridium sp. in a Syke's monkey (Cercopithecus albogulars) from Giza Zoological Gardens, Egypt. J Parasitol 37:392-394.

246. Fain A (1952) Sur les acariens parasites du genre Pneumonyssus au Congo Belge. Description de deux espèces nouvelles chez le daman et le colobe. Rev Zool Bot Afr 45:358-382.

247. Fain A (1955) Deux nouveaux acariens de la famille Halarachnidae Oudemans, parasites des fosses nasales des singes au Congo Belge et au Ruanda-Urandi. Rev Zool Bot Afr 51:307-324.

248. Fain A (1956) Coenurus of Taenia brauni setti parasitic in man and animals from the Belgian Congo and Ruanda-Ufundi. Nature 178:1353.

249. Fain A (1957) L'acariase pulmonaire chez le chimpanzé et le gorille par des acariens du genre Pneumonyssus Banks. Rev Zool Bot Afr 56:234-242.

250. Fain A (1958) Un nouveau parasite de l'orang-utan Rhinophaga pongoicola $\mathrm{n} . \mathrm{sp}$. (Acarina-Halarachnidae). Rev Zool Bot Afr 58:323-327.

251. Fain A (1959) Les acariens du genre Pneumonyssus Banks, parasites endopulmonaires des singes au Congo Belge (Halarachnidae:Mesostigmata). Ann Parasitol Hum Comp 34:126-148.

252. Fain A (1959) Deux nouveaux acariens nasicoles chez un singe platyrrhinien Saimiri sciurea (L). Bull Soc Roy Zool Anvers 12:3-12.

253. Fain A (1961) Pneumonyssus duttoni Newstead et Todd (1906) est une espèce composite. Description des deux espèces du complex duttoni (Mesostigmata:Halarachnidae). Rev Zool Bot Afr 63:213-226.

254. Fain A (1961) Sur le statut de deux espèces d'acariens du genre Pneumonyssus Banks déscrites par H. Vitzthum. Désignation d'un neotype pour Pneumonyssus simicola Banks, 1901 (Mesostigmata:Halarachnidae). Z Parasitenk 21:141-150.

255. Fain A (1961) Le pentastomidés de l'Afrique Centrale. Ann Mus Roy Afr Centr Ser 8 Sci Zool 92:1-115.

256. Fain A (1962) Pangorillages pani g.n., sp. n. Acarien psorique du chimpanzé (Psoralqidae:Sarcoptiformes). Rev Zool Bot Afr 66:283-290.

257. Fain A (1963) Les acariens producteurs de gale chez les lemuriens et les singes avec une étude des Psoroptidae (Sarcoptiformes). Bull Inst Roy Sci Nat Belg 39:1-125.

258. Fain A (1964) Les Lemurnyssidae parasites nasicoles des Lorisidae africains et des Cebidae sud-américains. Description d'une espèce nouvelle (Acarina:Sarcoptiformes). Ann Soc Belge Med Trop 44:453-458.

259. Fain A (1965) Notes sur le genre Notoedres Railliet, 1893 (Sarcoptidae:Sarcoptiformes). Acarologia 7:321-342. 
260. Fain A (1965) Nouveaux genres et espèces d'acariens Sarcoptiformes parasites (note préliminaire). Rev Zool Bot Afr 72:252-256.

261. Fain A (1965) A review of the family Rhyncoptidae:Lawrence, parasitic on porcupines and monkeys (Acarina:Sarcoptiformes). In: Naegele JA (ed) Advances in acarology, vol II. Cornell University Press, Ithaca, NY, pp 135-159.

262. Fain A (1966) Pentastomida of snakes-their parasitological role in man and animals. Mem Inst Butantan (São Paulo) 33:167-174.

263. Fain A (1966) Les acariens producteurs de gale chez les lémuriens et les singes. II. Nouvelles observations avec description d'une espèce nouvelle. Acarologia 8:94-114.

264. Fain A (1967) Diagnoses d'acariens Sarcoptiformes nouveaux. Rev Zool Bot Afr 65:378-382.

265. Fain A (1968) Étude de la variabilité de Sarcoptes scabei avec une revision des Sarcoptidae. Acta Zool Pathol Antverp 47:3-196.

266. Fain A (1968) Notes sur trois acariens remarquables (Sarcoptiformes). Acarologia 10:276-291.

267. Fain A, Schobbens S (1947) Lésions histopathologiques produites per l'acarien parasite Pneumonyssus duttoni. Newst et Todd. Rev Zool Bot Afr 40:12-16.

268. Fain A, Mignolet G, Bereznay Y (1958) L'acariase des voies respiratoires chez les singes due Zoo d'Anvers. Bull Soc Roy Zool Anvers 9:15-19.

269. Fairbairn H (1948) The occurrence of a piroplasm Entopolypoides macaci, in East African monkeys. Ann Trop Med Parasitol 42:118.

270. Fairbrother RW, Hurst EW (1932) Spontaneous diseases observed in 600 monkeys. J Path Bact 35:867-873.

271. Faust EC (1928) Studies on Thelazia callipaeda. Railliet and Henry, 1910. J Parasitol 15:75-86.

272. Faust EC (1933) Experimental studies on human and primate species of Strongyloides. II. The development of Strongyloides in the experimental host. Amer J Hyg 18:114-132.

273. Faust EC (1935) Notes on helminths from Panama. III. Filarial infection in the marmosets, Leontocebus geoffroyi (Pucheron) and Saimiri örstedii (Reinhardt) in Panama. Trans Roy Soc Trop Med Hyg 28:627.

274. Faust EC (1936) Strongyloides and strongyloidiasis. Rev Parasitol (Havana) 2:315-341.

275. Faust EC (1967) Athesmia (Trematoda:Dicrocoeliidae) Odhner, 1911 liver fluke of monkeys from Colombia, South America, and other mammalian hosts. Trans Amer Microse Soc 86:113-119.

276. Faust EC, Beaver PC, Jung RC (1968) Animal agents and vectors of human disease, 3rd ed. Lea \& Febiger, Philadelphia.

277. Fenstermacher R, Jellison WL (1932) Porcupine louse infesting the monkey. J Parasitol 18:294.

278. Fenwick A (1969) Baboons as reservoir hosts of Schistosoma mansoni. Trans Roy Soc Trop Med Hyg 63:557-567.

279. Fiennes RNT-W (1959) Report of the Society's pathologist for the year 1957. Proc Zool Soc London 132:129-146.

280. Fiennes RNT-W (1967) Zoonoses of primates. The epidemiology and ecology of simian diseases in relation to man. Weidenfeld and Nicolson, London.

281. Fiennes RNT-W (1972) Ectoparasites and vectors. In: Fiennes RNT-W (ed) Pathology of simian primates, part II. Infections and parasitic disease. S Karger, New York pp 158-176.

282. File SK (1974) Anatrichosoma ocularis sp. n. (Nematoda:Trichosomodidae) from the eye of the common tree shrew, Tupaia glis. J Parasitol 60:985-988.

283. File SK (1976) Probstmayria gombensis sp. n. (Nematoda:Atractidae) from the chimpanzee. J Parasitol 62:256-258. 
284. File SK, McGrew WC, Tutin CEG (1976) The intestinal parasites of a community of feral chimpanzees, Pan troglodytes schweinfurthii. J Parasitol 62:259-261.

285. Fineg J, Britz WE Jr, Cook JE, Edwards RH (1961) Clinical observations and methods used in the treatment of young chimpanzees. Air Force Missile Development Center, Holloman Air Force Base, New Mexico, Report Number AFMCDTR-61-12.

286. Finegold MJ, Seaquist ME, Doherty MJ (1968) Treatment of pulmonary acariasis in rhesus monkeys with an organic phosphate. Lab Anim Care 18:127-130.

287. Finkeldey W (1931) Pathologisch-anatomische Befunde bei der Oesophagostomiasis des Javeneraffen. Z Infektkr Haustiere 40:146-164. Cited by Ruch TC (1959) Diseases of laboratory primates. WB Saunders, Philadelphia.

288. Fischthal JH, Kuntz RE (1965) Six digenetic trematodes of mammals from North Borneo (Malaysia). Proc Helm Soc Washington, DC 32:154-159.

289. Flatt RE, Patton NM (1969) A mite infestation in squirrel monkeys (Saimiri sciureus). JAVMA 155:1233-1235.

290. Flynn RJ (1973) Parasites of laboratory animals. Iowa State University Press, Ames, IA.

291. Fonseca $F$ da (1951) Plasmódio de primata do Brasil. Mem Inst Oswaldo Cruz 49:543-553.

292. Foster AO, Johnson CM (1939) A preliminary note on the identity, life cycle, and pathogenicity of an important nematode parasite of captive monkeys. Amer J Trop Med 19:265-277.

293. Fox H (1926) Scabies in a male drill. Rep Lab Comp Pathol, Philadelphia, pp 27-28.

294. Fox H (1928) Balantidium in the red howler (Alouatta seniculus). Rep Lab Comp Pathol, Philadelphia, p 27.

295. Fox JG, Ediger RD (1970) Nasal leech infestation in the rhesus monkey. Lab Anim Care 20:1137-1138.

296. Fox JG, Hall WC (1970) Fluke (Gastrodiscoides hominis) infection in a rhesus monkey with related intussusception of the colon. JAVMA 157:714-716.

297. Fox JG, Diaz JR, Barth RA (1972) Nymphal Porocephalus clavatus in the brain of a squirrel monkey, Saimiri sciureus. Lab Anim Sci 22:908-910.

298. Frank H (1962) Durch Milben verursachte tödliche Lungenerkrankung bei einem Affen. Berl Münch Tier Woch 76:135-137.

299. Frank H (1982) Pathology of amebiasis in leaf monkeys (Colobidae). Proc 24th Int Symp Dis Zoo Anim, pp 321-326.

300. Fremming BD, Vogel FS, Benson RE, Young RJ (1955) A fatal case of amebiasis with liver abscesses and ulcerative colitis in a chimpanzee. JAVMA 126:406-407.

301. Fremming BD, Harris MD Jr, Young RJ, Benson RE (1957) Preliminary investigation into the life cycle of the monkey lung mite (Pneumonyssus foxi). Amer J Vet Res 18:427-428.

302. Frenkel JK (1971) Protozoal diseases of laboratory animals. In: Marcial-Rojas RA (ed) Pathology of protozoal and helminthic diseases. Williams and Wilkins, Baltimore, pp 318-369.

303. Frenkel JK (1974) Advances in the biology of sporozoa. Z Parasitenk 45:125-162.

304. Frenkel JK (1976) Angiostrongylus costaricensis infections. In: Binford CH, Connor $\mathrm{DH}$ (eds) Pathology of tropical and extraordinary diseases, an atlas, vol II, section 9. Diseases caused by other nematodes; Chapter 10. Angiostrongyliasis. Armed Forces Institute of Pathology, Washington, DC, pp 452-454.

305. Fuerstenberg MHF (1861) Die Kraetzmilben der Menschen und Tiere. Englemann, Leipzig.

306. Furman DP (1954) A revision of the genus Pneumonyssus (Acarina:Halarachnidae). J Parasitol 40:31-42.

307. Gardiner CH (1982) Syllabus: identification of animal parasites in histologic section. Reg Vet Pathol, AFIP, Washington, DC, pp 1-71. 
308. Gardiner CH, Nold JB, Sanders JE (1982) Diagnostic exercise. Lab Anim Sci 32:601-602.

309. Gardner MB, Esra G, Cain MJ, Rossman S, Johnson C (1978) Myelomonocytic leukemia in an orangutan. Vet Pathol 15:667-770.

310. Garner E (1967) Dipetalonema gracile infection in squirrel monkeys (Saimiri sciureus). Lab Anim Dig 3:16-17.

311. Garner E, Hemrick R, Rudiger H (1967) Multiple helminth infections in cinnamonringtailed monkeys (Cebus albifrons). Lab Anim Care 17:310-315.

312. Garner FM, Stookey JL (1968) Syllabus: diseases of nonhuman primates. Amer Reg Path, AFIP, Washington, DC, pp 22-28, 36-53.

313. Garnham PCC (1947) Exoerythrocytic schizogony in Plasmodium kochi Laveran: a preliminary note. Trans Roy Soc Trop Med Hyg 40:719-722.

314. Garnham PCC (1948) The development cycle of Hepatocystis (Plasmodium) kochi in the monkey host. Trans Roy Soc Trop Med Hyg 41:601-616.

315. Garnham PCC (1950) Blood parasites of East African vertebrates with a brief description of exoerythrocytic schizogony in Plasmodium pitmani. Parasitology 40:328-337.

316. Garnham PCC (1959) A new sub-species of Plasmodium cynomolgi. Riv Parasitol 20:273-278.

317. Garnham PCC (1963) Distribution of simian malaria parasites in various hosts. J Parasitol 49:905-911.

318. Garnham PCC (1963) A new sub-species of Plasmodium knowlesi in the long-tailed macaque. J Trop Med Hyg 66:156-158.

319. Garnham PCC (1973) Distribution of malaria parasites in primates, insectivores and bats. Symp Zool Soc London 33:377-404.

320. Garnham PCC, Uilenberg G (1975) Malaria parasites of lemurs. Ann Parasitol $50: 409-418$.

321. Garnham PCC, Lainson R, Gunders AE (1956) Some observations on malaria parasites in a chimpanzee, with particular reference to the persistence of Plasmodium reichenowi and Plasmodium vivax. Ann Soc Belge Med Trop 36:811-822.

322. Garnham PCC, Lainson R, Cooper W (1958) The complete life cycle of a new strain of Plasmodium gonderi from the drill (Mandrillus leucophaeus), including its sporogony in Anopheles aztecus and its preerythrocytic schizogony in the rhesus monkey. Trans Roy Soc Trop Med Hyg 2:509-517.

323. Garnham PCC, Heisch RB, Minter DM (1961) The vector of Hepatocystis (Plasmodium) kochi; the successful conclusion of observations in many parts of tropical Africa. Trans Roy Soc Trop Med Hyg 55:497-502.

324. Garnham PCC, Gonzales-Mugaburu L (1962) A new trypanosome in Saimiri monkeys from Colombia. Rev Inst Med Trop S Paulo 4:79-84.

325. Garnham PCC, Rajapaksa N, Peters W, Killick-Kendrick R (1972) Malaria parasites of the orang-utan (Pongo pygmaeus). Ann Trop Med Parasitol 66:287-294.

326. Gay DM, Branch A (1927) Pulmonary acariasis in monkeys. Amer J Trop Med 7:49-55.

327. Gebauer O (1933) Beitrag zur Kenntnis von Nematoden aus Affenlungen. Z Parasitenk 5:724-734.

328. Gedoelst L (1916) Notes sur la faune parasitaire du Congo Belge. Rev Zool Afr 5:1-90.

329. Geiman QM (1964) Shigellosis, amebiasis, and simian malaria. Lab Anim Care 14:441-454.

330. Geisel O, Krampitz HE, Willaert E (1975) Invasive amoebiasis caused by Entamoeba histolytica in a douc langur (Pygathrix nemaeus L. 1771). Berlin Muench Tieraerztl Woch 88:52-55.

331. Gisler DB, Benson RE, Young RJ (1960) Colony husbandry of research monkeys. Ann NY Acad Sci 85:758-768. 
332. Gleason NN, Wolfe RE (1974) Entopolypoides macaci (Babesiidae) in Macaca mulatta. J Parasitol 60:844-847.

333. Goldberger J, Crane C (1911) A new species of Athesmia (A. foxi) from a monkey. Bull Hyg Lab 71:48-55.

334. Goldman L, Feldman MD (1949) Human infestation with scabies of monkeys. Arch Dermatol Syphilol 59:175-178.

335. Goldsmid JM (1974) The intestinal helminthzoonoses of primates in Rhodesia. Ann Soc Belge Med Trop 54:87.

336. Goldsmid JM, Rogers S (1978) A parasitological study on the chacma baboon (Papio ursinus) from the Northern Transvaal. J So Afr Vet Assoc 49:109-111.

337. Gonder R, Von-Berenberg-Gossler H (1908) Untersuchungen über Malariaplasmodien der Affen. Malar Lpz 1:47-56.

338. Goussard B, Collet J-Y, Garin Y, Tutin CEG, Fernandez M (1983) The intestinal entodiniomorph ciliates of wild lowland gorillas (Gorilla gorilla gorilla) in Gabon, West Africa. J Med Primatol 12:239-249.

339. Graham GL (1960) Parasitism in monkeys. Ann NY Acad Sci 85:842-860.

340. Grigorova O, Nesturch M (1934) Filariasis in a young chimpanzee. Trans Lab Exp Biol, Moscow 6:210-211.

341. Grinker JA, Karlin DA, Estrella PM (1962) Lung mites: pulmonary acariasis in the primate. Aerosp Med 33:841-844.

342. Groot H (1951) Nuevo foco de trypanosomiasis humana en Colombia. Anales Soc Biol Bogota 4:220-221.

343. Groot H, Renjifo S, Uribe C (1951) Trypanosoma ariarii, n. sp., from man, found in Colombia. Amer J Trop Med 31:673-691.

344. Grzimek B (1951) Tod durch Lungenmilben bei einem Schimpansen. Zool Gart Lpz 18:249.

345. Guilloud NB, King AA, Lock A (1965) A study of the efficacy of thiabendazole and dithiazanine iodide-piperazine citrate suspension against intestinal parasites in the Macaca mulatta. Lab Anim Care 15:354-358.

346. Gupta NK, Dutt K (1975) On three nematode parasites of the genus Subulura Molin, 1860 from India. Riv Parassitol 36:185-188.

347. Haaf E, Soest van AH (1964) Oesophagostomiasis in man in North Ghana. Trop Geogr Med 16:49-53.

348. Habermann RT, Menges RW (1968) Filariasis (Acanthocheilonema perstans) in a gorilla (a case history). Vet Med Sm Anim Clin 63:1040-1043.

349. Habermann RT, Williams FP Jr (1957) Diseases seen at necropsy of 708 Macaca mulatta (rhesus monkey) and Macaca philippinensis (cynomolgus monkey). Amer J Vet Res 18:419-426.

350. Habermann RT, Williams FP Jr (1958) The identification and control of helminths in laboratory animals. J Natl Cancer Inst 20:979-1009.

351. Habermann RT, Williams FP Jr, Thorp WTS (1954) Identification of some internal parasites of laboratory animals. Public Health Service Publ No 343, US Dept of Health, Education, and Welfare.

352. Haddow AJ, Williams MC, Woodall JP, Simpson DIH, Goma LKH (1964) 12 Isolations of Zika virus from Aedes stegomyia africanas (Theobald) taken in and above a Uganda forest. Bull World Health Org 31:57-69.

353. Halberstädter L, von Prowazek S (1907) Untersuchungen über die Malaria-parasiten der Affen. Arb Gesundh Amt, Berlin 26:37-43.

354. Hamerton AE (1932) Report on the deaths occurring in the Society's gardens during the year 1931. Proc Zool Soc London 103:613-638.

355. Hamerton AE (1933) Report on deaths occurring in the Society's gardens during the year 1932. Proc Zool Soc London 104:451-482.

356. Hamerton AE (1937) Report on the deaths occurring in the Society's gardens during 1936. Proc Zool Soc London 107:443-474. 
357. Hamerton AE (1938) Report on the deaths occurring in the Society's gardens during the year 1937. Proc Zool Soc London 108:489-526.

358. Hamerton AE (1941-1942) Report on the deaths occurring in the Society's gardens during 1939-1940. Proc Zool Soc London 111:151-184.

359. Hamerton AE (1943) Report on the deaths occurring in the Society's gardens during 1942. Proc Zool Soc London 113:149.

360. Harper JS III, Rice JM, London WT, Sly DL, Middleton C (1982) Disseminated strongyloidiasis in Erythrocebus patas. Amer J Primatol 3:89-98.

361. Hartman HA (1961) The intestinal fluke (Fasciolopsis buski) in a monkey. Amer J Vet Res 22:1123-1126.

362. Hashimoto I, Honjo S (1966) Survey of helminth parasites in cynomologus monkeys (Macaca irus). Jap J Med Sci Biol 19:218.

363. Hawking F (1972) Entopolypoides macaci, a Babesia-like parasite in Cercopithecus monkeys. Parasitology 65:89-109.

364. Hawking F, Webber WAF (1955) Dirofilaria aethiops Webber, 1955, a filorial parasite of monkeys. II. Maintenance in the laboratory. Parasitology 45:378-387.

365. Hayama S, Nigi H (1963) Investigation on the helminth parasites in the Japan Monkey Centre during 1959-61. Primates 4:97-112.

366. Healy GR, Hayes NR (1963) Hydatid disease in rhesus monkeys. J Parasitol 49:837.

367. Healy GR, Myers BJ (1973) Intestinal helminths. In: Bourne GH (ed) The chimpanzee, vol 6. University Park Press, Baltimore, pp 265-296.

368. Hegner RW (1934) Specificity in the genus Balantidium based on size and shape of body and macronucleus with descriptions of six new species. Amer J Hyg 19:38-67.

369. Hegner RW (1934) Intestinal protozoa of chimpanzees. Amer J Hyg 19:480-501.

370. Hegner RW (1935) Intestinal protozoa from Panama monkeys. J Parasitol 21:60-61.

371. Hegner RW, Chu HJ (1930) A survey of protozoa parasitic in plants and animals of the Philippine Islands. Philippine J Sci 43:451-482.

372. Held JR (1969) Primate malaria. Ann NY Acad Sci 162:587-593.

373. Held JR, Whitney RA Jr (1978) Epidemic diseases of primate colonies. In: Chivers DJ, Ford EHR (eds) Recent advances in primatology, vol 4. Medicine. Academic, New York, pp 23-41.

374. Held JR, Contacos PG, Coatney GR (1967) Studies of the exoerythrocytic stages of simian malaria. I. Plasmodium fieldi. J Parasitol 53:225-232.

375. Helwig FC (1925) Arachnid infection in monkeys (Pneumonyssus foxi of Weidman). Amer J Pathol 1:389.

376. Henderson JD Jr, Webster WS, Bullock BC, Lehner NDM, Clarkson TB (1970) Naturally occurring lesions seen at necropsy in eight woolly monkeys (Lagothrix sp.). Lab Anim Care 20:1087-1097.

377. Hendricks LD (1974) A redescription of Isospora arctopitheci Rodhain, 1933 (Protozoa:Eimeriidae) from primates of Panama. Proc Helminthol Soc Washington, DC 41:229-233.

378. Hendricks LD (1977) Host range characteristics of the primate coccidian Isospora arctopitheci Rodhain 1933 (Protozoa:Eimeriidae). J Parasitol 63:32-35.

379. Herman CM, Schroeder CR (1939) Treatment of amoebic dysentery in an orangutan. Zoologica 24:339.

380. Herman LH (1967) Gastrodiscoides hominis infestation in two monkeys. Vet Med 62:355-356.

381. Hessler J, Woodard J, Tucek P (1971) Lethal toxoplasmosis in a woolly monkey. JAVMA 159:1588-1594.

382. Heuschele WP (1961) Internal parasitism of monkeys with the pentastomid, Armillifer armillatus. JAVMA 139:911-912.

383. Hickey TE, Kelly WA, Sitzman JE (1983) Demodectic mange in a tamarin (Saguinus geoffroyi). Lab Anim Sci 33:192-193. 
384. Hill WCO (1951) Report of the Society's prosector for the year 1950. Proc Zool Soc London 121:641-650.

385. Hill WCO (1953) Report of the Society's prosector for the year 1952. Proc Zool Soc London 123:227-251.

386. Hill WCO (1954) Report of the Society's prosector for the year 1953. Proc Zool Soc London 124:303-311.

387. Hill WCO, Porter A, Southwich MD (1952) The natural history, endoparasites, and pseudoparasites of the tarsiers (Tarsius carbonarius) recently living in the Society's menagerie. Proc Zool Soc London 122:79-119.

388. Hoare CA (1932) On protozoal blood parasites collected in Uganda. Parasitology $24: 210-224$.

389. Hoare CC (1958) The enigma of host-parasite relations in amebiasis. Rice Inst Pamphlet 45:23-35.

390. Holmes DD, Kosanke SD, White GL (1980) Fatal enterobiasis in a chimpanzee. JAVMA 177:911-913.

391. Honigberg BM, Lee JJ (1959) Structure and division of Trichomonas tenax (O. F. Müller). Amer J Hyg 69:177-201.

392. Honjo R, Imaizumi K (1965) Diseases observed in monkeys. Bull Exp Anim $14: 162-163$.

393. Honjo S, Muto K, Fujiwara T, Suzuki Y, Imaizumi K (1963) Statistical survey of internal parasites in cynomolgus monkeys (Macaca irus). Jap J Exp Med $16: 217-224$.

394. Hoogstraal H (1956) African Ixodoidea. I. Ticks of the Sudan (with special reference to Equatoria province and with preliminary reviews of the genera Boophilus, Margaropus, and Hyalomma). US Navy Dept Washington, DC Res Rept NM 005 050.29.07.

395. Hoogstrall H, Theiler G (1959) Ticks (Ixodoidea, Ixodidae) parasitizing lower primates in Africa, Zanzibar, and Madagascar. J Parasitol 45:217-222.

396. Hopkins GHE (1949) The host associations of the lice of mammals. Proc Zool Soc London 119:387-604.

397. Houser WD, Paik SK (1971) Hydatid disease in a macaque. JAVMA 159:15741577.

398. Howard EB, Gendron AP (1980) Echinococcus vogeli infection in higher primates at the Los Angeles zoo. In: Montali RJ, Migaki G (eds) The comparative pathology of zoo animals. Smithsonian Institution Press, Washington, DC, pp 379-382.

399. Howard LM, Cabrera BD (1961) Simian malaria in the Philippines. Science 134:555-556.

400. Hsu C-K, Melby EC Jr (1974) Isospora callimico, n. sp. (Coccidia Eimeriidae) from Göldi's marmoset (Callimico goeldii). Lab Anim Sci 24:476-479.

401. Hsü HF, David JR, Hsü SYL (1969) Histopathological lesions of rhesus monkeys and chimpanzees infected with Schistosoma japonicum. Z Tropenmed Parasitol 20:184-205.

402. Hsü SYL, Hsü HF (1968) A chimpanzee naturally infected with Schistosoma mansoni: Its resistance against a challenge infection of $S$. japonicum. Trans Roy Soc Trop Med Hyg 62:901-902.

403. Hubbard GB, Butcher WI (1983) What's your diagnosis? Passengers. Trematodiasis and typhlitis caused by Gastrodiscoides hominis. Lab Anim 12:12, 14.

404. Huff CG, Hoogstraal H (1963) Plasmodium lemuris n. sp. from Lemur collaris. J Inf Dis 112:233-236.

405. Hull WB (1970) Respiratory mite parasites in non-human primates. Lab Anim Care $20: 402$.

406. Hunt RD, Jones TC, Williamson M (1970) Mechanisms of parasitic damage and the host response. Lab Anim Care 20:345-353.

407. Hunt RD, Anderson MP, Chalifoux LV (1978) Spontaneous infectious diseases of marmosets. Prim Med 10:239-253. 
408. Ilievski V, Esber H (1969) Hydatid disease in a rhesus monkey. Lab Anim Care 19:199-204.

409. Inglis WG (1961) The oxyurid parasites (nematoda) of primates. Proc Zool Soc London 136:103-122.

410. Inglis WG, Cosgrove GE (1965) The pinworm parasites (Nematoda:Oxyuridae) of the Hapalidae (Mammalia:Primates). Parasitology 55:731-737.

411. Inglis WG, Dunn FL (1963) The occurrence of Lemuricola (Nematoda: Oxyurinae) in Malaya: with description of a new species. Z Parasitenk 23:354-359.

412. Inglis WG, Dunn FL (1964) Some Oxyurids (Nematoda) from neotropical primates. Z Parasitenk 24:83-87.

413. Innes JRM, Hull WB (1972) Endoparasites-lung mites. In: Fiennes RNT-W (ed) Pathology of simian primates. Part II. Infections and parasitic diseases. S Karger, New York, pp 177-193.

414. Innes JRM, Colton MW, Yevich PP, Smith CL (1954) Pulmonary acariasis as an enzootic disease caused by Pneumonyssus simicola in imported monkeys. Amer $\mathbf{J}$ Pathol 30:813-835.

415. Inoki S, Takemura S, Makiura Y, Hotta F (1942) Studies on Plasmodium inui var. Cyclopsis n. sp., new malaria parasite found in Formosan macaques (Macaca cyclopsis). Osaka Igakkuizassi 41:1327-1343.

416. Irving GW III (1972) Parasitology. In: Selected topics in laboratory animal medicine. Vol VIII. Aeromedical Review 2-72. USAF School of Aerospace Medicine, Aerospace Medical Division (AFSC), Brooks AFB, TX, pp 1-44.

417. Irving GW III (1972) Zoonoses of primates. In: Selected topics in laboratory animal medicine. Vol XIV. Aeromedical Review 13-72. US Air Force School of Aerospace Medicine, Aerospace Medical Division (AFSC), Brooks, AFB, TX.

418. Itakura C, Nigi $H$ (1968) Histopathological observations on two spontaneous cases of toxoplasmosis in the monkey (Lemur catta). Jap J Vet Sci 30:341-346.

419. Jaskoski BJ (1960) Physalopteran infection in an orangutan. JAVMA 137:307.

420. Jensen JM, Huntress SL (1982) Capillaria hepatica infestation in a gelada baboon (Theropithecus gelada) troop. Amer Assoc Zoo Vet Ann Proc 48-49.

421. Jessee MT, Schilling PW, Stunkard JA (1970) Identification of intestinal helminth eggs in Old World primates. Lab Anim Care 20:83-87.

422. Johnsen DO, Gould DJ, Tanticharoenyos P, Diggs CL, Wooding WL (1970) Experimental infection of gibbons with Dirofilaria immitis. Trans Roy Soc Trop Med Hyg 64:937-938.

423. Johnson CM (1941) Observations on natural infections of Endamoeba histolytica in Ateles and rhesus monkeys. Amer J Trop Med 21:49-61.

424. Jones DM (1982) Veterinary aspects of the maintenance of orang-utans in captivity. In: Boer de LEM (ed) The orang-utan: its biology and conservation. Dr W Junk, The Hague, pp 171-199.

425. Jones ND, Brooks DR, Harris RL (1980) Macaca mulatta-a new host for Choanotaenia Cestodes. Lab Anim Sci 30:575-577.

426. Jones SR (1973) Toxoplasmosis: a review. JAVMA 163:1038-1042.

427. Jones TC, Hunt RD (1983) Diseases due to protozoa. Veterinary pathology, 5th ed. Lea \& Febiger, Philadelphia, pp 719-777.

428. Jones TC, Hunt RD (1983) Diseases caused by parasitic helminths and arthropods. Veterinary pathology, 5th ed. Lea \& Febiger, Philadelphia, pp 778-879.

429. Jortner BS, Percy DH (1978) The nervous system. In: Benirschke K, Garner FM, Jones TC (eds) Pathology of laboratory animals, chapter 5, vol I. Springer-Verlag, New York, pp 320-421.

430. Kagan IG, Allain DS, Norman L (1959) An evaluation of the hemagglutination and flocculation tests in the diagnosis of Echinococcus disease. Amer Trop Med Hyg $8: 51-55$.

431. Kalter SS (1980) Infectious diseases of the great apes of Africa. J Reprod Fertil Suppl 28:149-159. 
432. Kalter SS, Heberling RL (1978) Health hazards associated with newly imported primates and how to avoid them. In: Chivers DJ, Ford EHR (eds) Recent advances in primatology, vol 4. Medicine. Academic, New York, pp 5-21.

433. Karr SL Jr, Wong MM (1975) A survey of sarcocystis in nonhuman primates. Lab Anim Sci 25:641-645.

434. Karr SL Jr, Henrickson RV, Else JG (1979) A survey for Anatrichosoma (Nematoda: Trichinellida) in wild-caught Macaca mulatta. Lab Anim Sci 29:789-790.

435. Karr SL Jr, Henrickson RV, Else JG (1980) A survey for intestinal helminths in recently wild-caught Macaca mulatta and results of treatment with mebendazole and thiabendazole. J Med Primatol 9:200-204.

436. Kasa TJ, Lathrop GD, Dupuy HJ, Bonney CH, Toft JD II (1977) An endemic focus of Trypanosoma cruzi infection in a subhuman primate research colony. JAVMA 171:850-854.

437. Kaufmann AF, Morris G, Richardson JH, Healy G, Kaplan W (1970) A survey of newly arrived South American monkeys for potential human pathogens. In: Primate zoonoses surveillance. Report No. 1. Centers for Disease Control, Atlanta, GA.

438. Keeling ME, McClure HM (1972) Clinical management, diseases and pathology of the gibbon and siamang. In: Rumbaugh DM (ed) Gibbon and siamang, vol 1. S Karger, Basel, pp 207-249.

439. Keeling ME, McClure HM (1974) Pneumococcal meningitis and fatal enterobiasis in a chimpanzee. Lab Animal Sci 24:92-95.

440. Keeling ME, Wolf RH (1975) Medical management of the rhesus monkey. In: Bourne GH (ed) The rhesus monkey, vol 2. Academic Press, New York, pp 11-96.

441. Kellogg VL (1913) Ectoparasites of the monkeys, apes and man. Science 38:601.

442. Kennard MA (1981) Abnormal findings in 246 consecutive autopsies on monkeys. Yale J Biol Med 13:701-712.

443. Kessel JF (1928) Intestinal protozoa of monkeys. Univ Calif (Berkeley) Publ Zool 31:275-306.

444. Kessel JF, Johnstone HG (1949) The occurrence of Endamoeba polecki Prowazek, 1912, in Macaca mulatta and in man. Amer J Trop Med 29:311-317.

445. Kessel JF, Kaplan F (1949) The effect of certain arsenicals on natural infections of Endamoeba histolytica and of Endamoeba polecki in Macaca mulatta. Amer J Trop Med 29:319-322.

446. Kessler MJ (1982) Nasal and cutaneous anatrichosomiasis in the free-ranging rhesus monkeys (Macaca mulatta) of Cayo Santiago. Amer J Primatol 3:55-60.

447. Kessler MJ, Yarbrough B, Rawlins RG, Berard J (1984) Intestinal parasites of the free-ranging Cayo Santiago rhesus monkeys (Macaca mulatta). J Med Primatol $13: 57-66$.

448. Keymer IF (1976) Report of the pathologist, 1973 and 1974. J Zool 178:456-493.

449. Kikuth W (1927) Piroplasmose bei Affen. Arch Schiffs Tropen Hyg 31:37-40.

450. Kim CS, Bang BG (1970) Nasal mites parasitic in nasal and upper skull tissues in the baboon (Papio sp.). Science 169:372-373.

451. Kim CS, Kalter SS (1972) Unilateral renal aplasia in an African baboon (Papio sp.). Folia Primatol 2:352.

452. Kim CS, Eugster AK, Kalter SS (1968) Pathologic study of the African baboon (Papio sp.) in his native habitat. Primates 9:93-104.

453. Kim CS, Bang FB, DiGiacomo RF (1972) Hemagglutination assay of antibodies associated with pulmonary acariasis in rhesus monkeys. Infect Immun 5:138-140.

454. Kim JCS (1974) Distribution and life cycle stages of lung mites (Pneumonyssus sp.). J Med Primatol 3:105-119.

455. Kim JCS (1976) Scanning electron microscopic studies of simian lung mites. J Med Primatol 5:3.

456. Kim JCS (1977) Pulmonary acariases in Old World monkeys. Vet Bull 47:249-255.

457. Kim JCS (1980) Pulmonary acariasis in Old World monkeys: a review. In: Montali 
RJ, Migaki G (eds) The comparative pathology of zoo animals. Smithsonian Institution Press, Washington, DC, pp 383-394.

458. Kim JCS, Kalter SS (1975) Pathology of pulmonary acariasis in baboons (Papio sp.). J Med Primatol 4:70.

459. Kim JCS, Abee CR, Wolf RH (1978) Balantidiosis in a chimpanzee (Pan troglodytes). Lab Anim 12:231-233.

460. Kim KC, Emerson KC (1968) Descriptions of two species of Pediculidae (Anoplura) from great apes (Primates, Pongidae). J Parasitol 54:690-695.

461. King NW Jr (1976) Synopsis of the pathology of new world monkeys. In: First interAmerican conference on conservation and utilization of American nonhuman primates in biomedical research. Scientific Publ No 317, Pan American Health Organization, Pan American Sanitary Bureau Regional Office of the WHO, Washington, DC, pp 169-198.

462. Kingston N, Cosgrove GE (1967) Two new species of Platynosomum (Trematode:Dicrocoeliidae) from South American monkeys. Proc Helminthol Soc Washington, DC 34:147-151.

463. Kirby $\mathrm{H} \mathrm{Jr}$ (1928) Notes on some parasites from chimpanzees. Proc Soc Exp Biol Med 25:698-700.

464. Knezevich AL, McNulty WP Jr (1970) Pulmonary acariasis (Pneumonyssus simicola) in colony bred Macaca mulatta. Lab Anim Care 20:693-696.

465. Knowles R (1919) Notes on the monkey plasmodium and on some experiments in malaria. Ind J Med Res 7:195-202.

466. Knowles R, Das Gupta BM (1932) A study of monkey malaria and its experimental transmission to man. Ind Med Gaz 67:213-268.

467. Knowles R, Das Gupta BM (1936) Some observations on the intestinal protozoa of macaques. Ind J Med Res 24:547-556.

468. Kobayashi H (1925) On the animal parasites in Korea. Jap Med World 5:9-16.

469. Kohn DF, Haines DE (1982) Diseases of the Prosimii: a review. In: Haines DE (ed) The lesser bushbaby (Galago) as an animal model: selected topics. CRC, Boca Raton, FL, pp 285-301.

470. Kopciowska L, Nicolau S (1938) Toxoplasmose spontanée du chimpanzé. CR Soc Biol (Paris) 129:179-181.

471. Korté WF de (1905) On the presence of a sarcosporidium in the thigh muscles of Macaca rhesus. J Hyg 5:451-452.

472. Kovatch RM, White JD (1972) Cryptosporidiosis in two juvenile rhesus monkeys. Vet Pathol 9:426-440.

473. Krascheninnikow S, Wenrich DH (1958) Some observations on the morphology and division of Balantidium coli and Balantidium caviae (?). J Protozool 5:196-202.

474. Kreis HA (1932) A new pathogenic nematode of the family Oxyuroidea, Oxyuronema atelophora n. g., n. $\mathrm{sp}$ in the red-spider monkey, Ateles geoffroyi. J Parasitol 18:295-302.

475. Kreis HA (1945) Beiträge zur Kenntnis parasitischer Nematoden. XII. Parasitische Nematoden aus den Tropen. Rev Suisse Zool 52:551.

476. Kreis HA (1955) Beiträge zur Kenntnis parasitischer Nematoden. XVIII. Das Genus Probstmayria Ransom, 1907. Schweiz Arch Tierheilkd 97:422-433.

477. Krishnamoorthy RV, Srihari K, Rahaman H, Rajasekharaiah GL (1978) Nematode parasites of the slender loris, Loris tardigradus. Proc Ind Acad Sci 87B:17-22.

478. Kugi G, Sawada I (1970) Mathevotaenia brasiliensis n. sp., a tapeworm from the squirrel monkey, Saimiri sciureus. Jap J Parasitol 19:467-470.

479. Kuhn H-J, Ludwig HW (1967) Die Affenläuse der Gattung Pedicinus. Z Zool Syst Evolutions 5:144-256.

480. Kumar V, DeMeurichy W (1982) Efficacy of Yomesan against Bertiella sp (Anoplocephalidae/Cestoda) of a chimpanzee, Pan schweinfurthii. Riv Parassitol 43: 161-163. 
481. Kumar V, DeMeurichy W, Van Peer L (1980) Microscopic pathology of liver of capuchin monkey (Cebus albifrons) infected with Athesmia foxi (Dicrocoelidae:Trematoda): a pictorial illustration. ACTA Zool Pathol Antverp 75:71-77.

482. Kuntz RE (1972) Trematodes of the intestinal tract and biliary passages. In: Fiennes RNT-W (ed) Pathology of simian primates, part II. Infectious and parasitic diseases. S Karger, Basel, pp 104-123.

483. Kuntz RE (1973) Models for investigation in parasitology. In: Bourne GH (ed) Nonhuman primates in biomedical research. Academic, New York, pp 167-201.

484. Kuntz RE (1982) Significant infections in primate parasitology. J Hum Evol $11: 185-194$.

485. Kuntz RE, Moore JA (1973) Commensals and parasites of African baboons (Papio cynocephalus L. 1766) captured in rift valley province of central Kenya. J Med Primatol 2:236-241.

486. Kuntz RE, Myers BJ (1966) Parasites of baboons (Papio doguera Pucheran, 1856) captured in Kenya and Tanzania, East Africa. Primates 7:27-32.

487. Kuntz RE, Myers BJ (1967) Microbiological parameters of the baboon (Papio sp): parasitology. In: Vagtborg $\mathrm{H}$ (ed) The baboon in medical research, vol 2. University of Texas Press, Austin, TX, pp 741-755.

488. Kuntz RE, Myers BJ (1967) Parasites of the Kenya baboon: arthropods, blood protozoa and helminths. Primates 8:75-82.

489. Kuntz RE, Myers BJ (1967) Primate cysticercosis: Taenia hydatigena in Kenya vervets (Cercopithecus aethiops Linnaeus, 1758) and Taiwan macaques (Macaca cyclopis Swinhoe, 1864). Primates 8:83-88.

490. Kuntz RE, Myers BJ (1969) A checklist of parasites and commensals reported for the Taiwan macaque (Macaca cyclopis Swinhoe, 1862). Primates 10:71-80.

491. Kuntz RE, Myers BJ (1969) Parasitic protozoa, commensals and helminths of chimpanzees imported from the Republic of the Congo. Proc 2nd Int Congr Primat, Atlanta GA, 1968, vol 3. S Karger, Basel/New York, pp 184-190.

492. Kuntz RE, Myers BJ (1972) Parasites of South American primates. Intern Zoo Yrbk 12:61-68.

493. Kuntz R, Myers BJ, Vice TC (1967) Intestinal protozoans and parasites of the gelada baboon (Theropithecus gelada Rüppel, 1835). Proc Helminthol Soc Washington, DC 34:65-66.

494. Kuntz RE, Myers BJ, Bergner JF Jr, Armstrong DE (1968) Parasites and commensals of the Taiwan macaque (Macaca cyclopis Swinhoe, 1862). Formosan Sci 22:120-136.

495. Kuntz RE, Myers BJ, Katzberg A (1970) Sparganosis and "proliferative-like" spargana in vervets and baboons from East Africa. J Parasitol 56:196-197.

496. Kuntz RE, Myers BJ, McMurray TS (1970) Trypanosoma cruzi-like parasites in the slow loris (Nycticebus coucang) from Malaysia. Trans Amer Micr Soc 89:304-307.

497. Kuntz RE, Myers BJ, Moore JA (1973) Parasitology. In: Kalter SS (ed) The baboon. Microbiology, clinical chemistry, and some hematological aspects. Primates in medicine, vol 8. S Karger, Basel, pp 79-104.

498. Kuntz RE, Huang T, Moore JA (1977) Patas monkey (Erythrocebus patas) naturally infected with Schistosoma mansoni. J Parasitol 63:166-167.

499. Kupper JL, Britz WE (1972) The squirrel monkey. In: Selected topics in laboratory animal medicine. Vol XVIII. Aeromedical Review 5-72. USAF School of Aerospace Medicine, Aerospace Medical Division (AFSC), Brooks AFB, TX, pp 1-16.

500. Laing ABG, Edeson JFB, Wharton RH (1960) Studies on filariasis in Malaya; the vertebrate hosts of Brugia malayi and B. pahangi. Ann Trop Med Parasit 54:92-99.

501. Lambert RA (1918) Echinococcus cysts in a monkey. Proc NY Path Soc 18:29-30.

502. Lambrecht FL, Dunn FL, Eyles DE (1961) Isolation of Plasmodium knowlesi from Philippine macaques. Nature 191:1117-1118.

503. Landois F, Hoepke H (1914) Eine endoparasitäre Milbe in der Lunge von Macacus rhesus. Zentralbl Bakteriol. Abt 1 73:384. 
504. Lang EM (1966) The care and breeding of anthropoids. Symp Zool Soc London 17:113-125.

505. Langeron M (1920) Note additionnelle sur une hémogrégarine d'un macaque. Bull Soc Path Exot 13:394.

506. Lapage G (1962) Mönnig's veterinary helminthology and entomology, 5th ed. Williams and Wilkins, Baltimore.

507. Lapage G (1968) Veterinary parasitology. Oliver and Boyd, Edinburgh/London.

508. Lapin BA (1962) Disease in monkeys within the period of acclimatization and during long-term stay in animal houses. In: Harris RJC (ed) The problems of laboratory. animal disease. Academic, New York, pp 143-149.

509. Lapin BA, Yakovleva LA (1960) Comparative pathology in monkeys. CC Thomas, Springfield, IL.

510. Lapin BA, Yakovleva LA (1963) Diseases of the cardiovascular system. In: Comparative pathology in monkeys. CC Thomas, Springfield, IL, pp 132-177.

511. Lasry JE, Sheridan BW (1965) Chagas' myocarditis and heart failure in the red uakari. Intern Zoo Yrbk 5:182-187.

512. Lavoipierre MMJ (1955) A description of a new genus of sarcoptiform mites and of three new species of Acarina parasitic on primates in the British Cameroons. Ann Trop Med Parasitol 49:299-307.

513. Lavoipierre MMJ (1955) The occurrence of a mange mite, Psoregates sp. (Acarina), in a West African monkey. Ann Trop Med Parasitol 49:351.

514. Lavoipierre MMJ (1958) Studies on the host-parasite relationships of filarialnematodes and their arthropod hosts. I. The sites of development and the migration of Loa loa in Chrysops silacea, the escape of the infective forms from the head of the fly, and the effect of the worm on its insect host. Ann Trop Med Parasitol 52:103-121.

515. Lavoipierre MMJ (1964) A new family of acarines belonging to the suborder Sarcoptiformes parasitic in the hair follicles of primates. Ann Natal Mus 16:1-18.

516. Lavoipierre MMJ (1964) A note on the family Psoralgidae (Acari:Sarcoptiformes) together with a description of two new genera and two new species parasitic on primates. Acarologia 6:342-352.

517. Lavoipierre MMJ (1970) A note on the sarcoptic mites of primates. J Med Entomol $7: 376-380$.

518. Leathers CW (1978) The prevalence of Hepatocystis kochi in African green monkeys. Lab Anim Sci 28:186-189.

519. Leathers CW (1978) Pulmonary acariasis in a infant, colony-born rhesus monkey (Macaca mulatta). Lab Anim Sci 28:102-103.

520. Lebel RR, Nutting WB (1973) Demodectic mites of subhuman primates. I. Demodex saimiri sp. n. (Acari:Demodicidae) from the squirrel monkey, Saimiri sciureus. J Parasitol 59:719-722.

521. Lee KJ, Lang CM, Hughes HC, Hartshorn RD (1981) Psorergatic mange (Acari: Psorergatidae) of the stumptail macaque (Macaca arctoides). Lab Anim Sci 31:77-79.

522. Lee RE, Williams RB Jr, Hull WB, Stein SN (1954) Significance of pulmonary acariasis in rhesus monkeys (Macaca mulatta). Fed Proc 13:85-86.

523. Leerhoy J, Jensen HS (1967) Sarcoptic mange in a shipment of cynomolgus monkeys. Nord Veterinarmed 19:128-130.

524. Lefrou G, Martignoles J (1955) Contribution à l'étude de Plasmodium kochi. Plasmodium des singes africans. Bull Soc Path Exot 48:227-234.

525. Leger M, Bédier E (1922) Hémogrégarine du cynocéphale, Papio sphinx E. Geoffrey. CR Soc Biol 87:933-934.

526. Leibegott G (1962) Pericarditis verminosa (strongyloides) beim Schimpansen. Virchows Arch Path Anat 335:211-225.

527. Levaditi C, Schoen R (1933) Présence d'un toxoplasme dans l'encéphale du cynocephalus babuin. Bull Soc Path Exot 26:402-405. 
528. Levine ND (1961) Protozoan parasites of domestic animals and of man. Burgess, Minneapolis.

529. Levine ND (1970) Protozoan parasites of nonhuman primates as zoonotic agents. Lab Anim Care 20:377-382.

530. Levine ND (1973) Protozoan parasites of domestic animals and of man, 2nd ed. Burgess, Minneapolis.

531. Levine ND (1976) Nematode parasites of domestic animals and of man. Burgess, Minneapolis.

532. Levine ND (1977) Nomenclature of Sarcocystis in the ox and sheep and of fecal coccidia of the dog and cat. J Parasitol 63:36-51.

533. Lichtenfels JR (1971) Morphological variation in the gullet nematode, Gongylonema pulchrum Molin, 1857, from eight species of definitive hosts with a consideration of gongylonema from Macacca spp. J Parasitol 57:348-355.

534. Lillie RD (1947) Reactions of various parasitic organisms in tissues to the Bauer Feulgen Gram and Gram-Weigert methods. J Lab Clin Med 32:76-88.

535. Lim-Boo-Liat (1974) New hosts of Angiostrongylus malaysiensis Bhaibulaya and Cross 1971, in Malaysia. Southeast Asian J Trop Med Pub Health 5:379-384.

536. Lindquist WD, Bieletzki J, Allison S (1980) Pterygodermatites sp. (Nematode: Rictulariidae) from primates in Topeka, Kansas Zoo. Proc Helminthol Soc Washington, DC 47:224-227.

537. Linstow von OFB (1899) Nematoden aus der Berliner zoologischen Sammlung. Mitt Zool Mus Berl 1(2)-1.

538. Linstow von OFB (1903) The American hookworm in chimpanzees. Amer Med $6: 611$.

539. Linstow von OFB (1912) Cestoda and cestodaria. In: Stilles and Hassall Indexcatalogue of medical and veterinary zoology. Bull 85 Hyg Lab US Publ Health and Mar Hosp Serv.

540. Little MD (1962) Experimental studies on the life cycle of Strongyloides. J Parasitol Suppl 48:41.

541. Little MD (1966) Comparative morphology of six species of Strongyloides (Nematoda) and redefinition of the genus. J Parasitol 52:69-84.

542. Loeb WF, Bannerman RM, Rininger BF, Johnson AJ (1978) Hematologic disorders. In: Benirschke K, Garner FM, Jones TC (eds) Pathology of laboratory animals, chapter 11, vol I. Springer-Verlag, New York, pp 1000-1021, 1032-1050.

543. Long GG, White JD, Stookey JL (1975) Pneumocystis carinii infection in splenectomized owl monkeys. JAVMA 167:651-654.

544. Loomis MR, Britt JO (1983) An epizootic of Entamoeba histolytica in colobus monkeys. Amer Assoc Zoo Vet Ann Proc, p 10.

545. Loomis MR, Britt JO, Gendron AP, Holshuh HJ, Howard EB (1983) Hepatic and gastric amebiasis in black and white colobus monkeys. JAVMA 183:1188-1191.

546. Lothe DF (1958) An immature Oesophagostomum sp. from an umbilical swelling in an African child. Trans Roy Soc Trop Med Hyg 52:12.

547. Lucker JT (1933) Gongylonema macrogubernaculum Lubimov, 1931: two new hosts. J Parasitol 19:243.

548. Lucker JT (1933) Two new hosts Gongylonema pulchrum Molin, 1857. J Parasitol 19:248.

549. Lushbaugh CC, Humason G, Gengozian N (1969) Intrauterine death from congenital Chagas' disease in laboratory marmosets (Saguinus fuscicollis labonotus). Amer J Trop Med 18:662-665.

550. Lussier G, Marois P (1964) Animal sarcosporidiosis in the province of Quebec. Can J Publ Health 55:243-246.

551. Machida M, Araki J, Koyama T, Kumada M, Horii Y, Imada I, Takasaka M, Honjo S, Matsubayashi K, Tibat T (1978) The life cycle of Streptopharagus pigmentatus (Nematoda, Spiruroidea) from the Japanese monkey. Bull Nat Sci Mus (Ser A) 4:1-9. 
552. MacKenzie PS (1979) Pathogenicity, identification and treatment of Prosthenorchis elegans infestation in squirrel monkeys (Saimiri sciureus). Prim Suppl 4:5-7.

553. MacKinnon DL, Dibb MJ (1938) Report on intestine protozoa of some mammals in the zoological gardens at Regent's Park. Proc Zool Soc London Ser B 108:323345.

554. Magalhaes Pinto R (1970) Occurrence of Subulura jacchi (Marcel, 1857) Railliet and Henry, 1913 (Nematoda, Subuluroidea) in a new host: Callithrix aurita coelestis (M. Ribeiro, 1924). Atas de Sociedade de Biologia do Rio De Janeiro 13:143145.

555. Mandour AM (1969) Sarcocystis nesbitti n. sp. from the rhesus monkey. J Protozool 16:353-354.

556. Manwell RD (1968) Simian malaria. In: Weinman D, Ristic M (eds) Infectious blood diseases of man and animals, vol II. Academic, New York, pp 78-88.

557. Manwell RD, Kuntz RE (1966) Hepatocystis in Formosan mammals with a description of a new species. J Protozool 13:670-672.

558. Maplestone PA (1931) Parasitic nematodes obtained from animals dying in the Calcutta Zoological Gardens. Pt 4-8. Rec Indian Mus 33:71-171.

559. Marinkelle CS (1966) Observations on man, monkey, and bat trypanosomes and their vectors in Colombia. Trans Roy Soc Trop Med Hyg 60:109-116.

560. Marinkelle CJ (1968) Trypanosoma lambrechti $\mathrm{n}$. sp. aislado de micos (Cebus albifrons) de Colombia. Caldasia 10:155-165.

561. Masbar S, Palmieri JR, Marwoto HA, Purnomo, Darwis F (1981) Blood parasites of wild and domestic animals from South Kalimantan (Borneo), Indonesia. Southeast Asian J Trop Med Pub Health 12:42-46.

562. Masse R, Geneste M, Thiery G (1965) Acariose pulmonaire du singe traitement, prophylaxie. Rec Méd Vét Ecole Alfort 141:1227-1234.

563. Mayer M (1907) Über Malaria beim Affen. Med Klin 3:579-580.

564. Mayer M (1933) Über einen neuen Blutparasiten des Affen (Entopolypoides macaci n. g. n. sp.). Arch Schiffs Tropen Hyg 37:504-505.

565. Mayer M (1934) Ein neuer, eigenartiger Blutparasit des Affen (Entopolypoides macaci n. g. et n. sp.). Zentr Bakteriol Parasitenk Abt I Orig 131:132-136.

566. Mazza S (1930) Doble parasitismo por filarias en monos Cebus del norte. 5a Reun Soc Argent Pat Reg N 1929 2:1140.

567. McCarrison R (1920) The effects of deficient dietaries on monkeys. Brit Med J Feb $21249-253$.

568. McClure GW (1932) Nematode parasites of mammals with a description of a new species, Wellcomia branickii from specimens collected in the New York Zoological Park, 1930. Zoologica NY 15:1.

569. McClure GW (1934) Nematode parasites of mammals from specimens collected in the New York Zoological Park, 1932. Zoologica NY 15:49.

570. McClure HM, Guilloud NB (1971) Comparative pathology of the chimpanzee. In: Bourne GH (ed) The chimpanzee, vol 4. Behavior, growth and pathology of chimpanzees. University Park Press, Baltimore, pp 103-272.

571. McClure HM, Strozier LM, Keeling ME, Healy GR (1973) Strongyloidosis in two infant orangutans. JAVMA 163:629-632.

572. McClure HM, Chapman WL Jr, Hooper BE, Smith FG, Fletcher OJ (1978) The digestive system. In: Benirschke K, Garner FM, Jones TC (eds) Pathology of laboratory animals, chapter 4, vol I. Springer-Verlag, New York, pp 176-317.

573. McConnell EE (1977) Parasitic diseases observed in free-ranging and captive baboons. Comp Path Bull 9:2.

574. McConnell EE, Basson PA, Devos V (1971) Nasal acariasis in the chacma baboon. Papio ursinus Kerr 1792. Onderstepoort J Vet Res 38:207.

575. McConnell EE, DeVos AJ, Basson PA, DeVos V (1971) Isopora papionis n. sp. (Eimeriidae) of the Chacma baboon Papio ursinus (Kess, 1792). J Protozool $18: 28-32$. 
576. McConnell EE, Basson PA, Thomas SE, DeVos V (1972) Oocysts of Isospora papionis in the skeletal muscle of Chacma baboons. Onderstepoort $\mathrm{J}$ Vet Res 39:113-116.

577. McConnell EE, Basson PA, DeVos V (1972) Laryngeal acariasis in the chacma baboon. JAVMA 161:678-682.

578. McConnell EE, Basson PA, DeVos V, Myers BJ, Kuntz RE (1972) A survey of diseases among 100 free-ranging baboons (Papio ursinus) from Krueger National Park. Onderstepoort J Vet Res 41(3):97-167.

579. McConnell EE, Basson PA, Wolstenholme B, DeVos V, Malherbe H (1973) Toxoplasmosis in "free-ranging" chacma baboons (Papio ursinus) from the Krueger National Park. Trans Roy Soc Trop Med Hyg 67:851-855.

580. McCoy OR (1936) Filarial parasites of monkeys of Panama. Amer J Trop Med 16:383-403.

581. McKissick GE, Ratcliffe HL, Koestner A (1968) Enzootic toxoplasmosis in caged squirrel monkeys. Saimiri sciureus. Pathol Vet 5:538-560.

582. Mendonca de MM (1983) Mathevotaenia cruzsilvai n. sp. (cestoda Anoplocephalidae), parasite of Macaca irus F. Cuvier, 1818. Bull Mus (Nat) d'Hist Nat A3:1081-1086.

583. Middleton CC (1966) Acanthocephala (Prosthenorchis elegans) infection in squirrel monkeys (Saimiri sciureus). Lab Anim Dig 2:16-17.

584. Middleton CC, Clarkson TB, Garner FM (1964) Parasites of squirrel monkeys (Saimiri sciureus). Lab Anim Care 14:335.

585. Migaki G, Seibold HR, Wolf RH, Garner FM (1971) Pathologic conditions in the patas monkey. JAVMA 159:549-556.

586. Miller JH (1959) Hepatocystis (= Plasmodium) kochi in the dog face baboon, Papio doguera. J Parasitol Suppl 45:53.

587. Miller JH (1959) The dog face baboon, Papio doguera, a primate reservoir host for Schistosoma mansoni in East Africa. J Parasitol 45:22-25.

588. Miller MJ, Bray RS (1966) Entamoeba histolytica infections in the chimpanzee (Pan satyrus). J Parasitol 52:386-388.

589. Moncol DJ, Batte EG (1966) Transcolostral infection of newborn pigs with Strongyloides ransomi. Vet Med 61:583-586.

590. Monnig HO (1920) Filaria nycticebi eine neue Filaria aus dem Nycticebus. Centralb Bakteriol 85:216-221.

591. Montali RJ, Bush M (1980) Diagnostic exercise. Lab Anim Sci 30:33-34.

592. Montali RJ, Bush M (1981) Rictulariasis in callitrichidae at the National Zoological Park. In: XXIII. Internationalen Symposiums über die Erkrankungen der Zootiere Halle/Saale. Akademie-Verlag, Berlin, pp 197-202.

593. Montali RJ, Gardiner CH, Evans RE, Bush M (1983) Pterygodermatites nycticebi (Nematoda:Spirurida) in golden lion tamarins. Lab Anim Sci 33:194-197.

594. Montgomery CA (1978) Muscle diseases. In: Benirschke K, Garner FM, Jones TC (eds) Pathology of laboratory animals, chapter 10, vol I. Springer-Verlag, New York, pp 841-853, 880-887.

595. Moore G, Myers BJ (1974) Parasites of non-human primates. In: Ann Proc Amer Assoc Zoo Vet, Washington, DC pp 79-86.

596. Moore JA, Kuntz RE (1975) Entopolypoides macaci Mayer 1934 in the African baboon (Papio cynocephalus L. 1776). J Med Primatol 4:1-7.

597. Moore JG (1970) Epizootic of acanthocephaliasis among primates. JAVMA 157:699-705.

598. Mooreman AE (1941) Balantidium coli and pinworm in a chimpanzee. J Parasitol 27:366.

599. Mortelman J, Vercruysse J, Kageruka P (1971) Three pathogenic intestinal protozoa of anthropoid apes: Entamoeba histolytica, Balantidium coli and Troglodytella abrassarti. In: Biegert J, Leutenegger W (eds) Proceedings of the Third International 
Congress of Primatology, vol 2. Neurobiology, immunology, cytology. S Karger, Basel, pp 187-191.

600. Morton HL (1969) Sparganosis in African green monkeys (Cercopithecus aethiops). Lab Anim Care 19:253-255.

601. Muller R, Ruedi D (1981) Gastric amebiasis in a proboscis monkey (Nasalis larvatus). ACTA Zool Pathol Antverp 76:9-16.

602. Mulligan HW (1935) Description of two species of monkey Plasmodium isolated from Silenus irus. Arch Protistenk 84:285-314.

603. Mullin SW, Orihel TC (1972) Tetrapetalonema dunni sp. n. (Nematoda:Filaroidea) from Malaysian tree shrews. J Parasitol 58:1047-1051.

604. Mullin SW, Colley FC, Stevens GS (1972) Coccidia of Malaysian mammals: new host records and descriptions of three new species of Eimeria. J Protozool 19:260-263.

605. Mullin SW, Dondero TT Jr, Sivanandam S, Dewey R (1972) Filarial parasites of Malaysian monkeys. Southeast Asian J Trop Med Publ Health 3:548-551.

606. Murphy JC, Fox JG, Shalev M (1979) Paragonimus westermani infection in a cynomolgus monkey. JAVMA 175:981-984.

607. Myers BJ (1970) Techniques for recognition of parasites. Lab Anim Care 20:342-344.

608. Myers BJ (1972) Echinococcosis, coenurosis, cysticercosis, sparganosis, etc. In: Fiennes RNT-W (ed) Pathology of simian primates. Part II. Infectious and parasitic diseases. S Karger, Basel, pp 124-143.

609. Myers BJ, Kuntz RE (1965) A checklist of parasites reported for the baboon. Primates 6:137-194.

610. Myers BJ, Kuntz RE (1967) Parasites of baboons taken by the Cambridge Mwanza expedition (Tanzania 1965). East Afr Med J 44:322-324.

611. Myers BJ, Kuntz RE (1968) Intestinal protozoa of the baboon Papio doguera Pucheran 1856. J Protozool 15:363-365.

612. Myers BJ, Kuntz RE (1969) Nematode parasites of mammals (Dermoptera, Primates, Pholidata, Rodentia, Carnivora, and Artiodactyla) from North Borneo (Malaysia). Can J Zool 47:419-421.

613. Myers BJ, Kuntz RE (1972) A checklist of parasites and commensals reported for the chimpanzee (Pan). Primates 13:433-471.

614. Myers BJ, Kuntz RE, Vice TE (1965) Hydatid disease in captive primates (Colobus and Papio). J Parasitol Suppl 51:22.

615. Myers BJ, Kuntz RE, Vice TE, Kim CS (1970) Natural infection of Echinococcus granulosus (Batsch, 1786) Rudolph, 1805 in the Kenya baboon (Papio sp.). Lab Anim Care 20:283-286.

616. Myers BJ, Kuntz RE, Malherbe H (1971) Intestinal commensals and parasites of the South African baboon (Papio cynocephalus). Trans Amer Micr Soc 90:80-83.

617. Myers BJ, Kuntz RE, Kamara JA (1973) Parasites and commensals of chimpanzees captured in Sierra Leone, West Africa. Pro Helminthol Soc Washington, DC 40:298-299.

618. Mysorekar NR, Chakravarti RN, Chawla LS, Chhuttani PN (1966) Diseases of rhesus monkeys. III. Large intestine. J Assoc Phys Ind 14:583-587.

619. Nagaty HF (1935) Parlitomosa zakii (Filariinae). A new genus and species and its microfilaria from Leontocebus rosalia. J Egypt Med Assoc 18:483-496.

620. Naquira C (1963) Estudio preliminar sobre la infeccion celomica de Triatoma infestans por Trypanosoma cruzi y Trypanosoma sp. de mono. Biol Santiago 35:3-8.

621. Napier JR, Napier PH (1967) A handbook of living primates. Academic, New York.

622. Narama I, Tsuchitani M, Umemura T, Tsuruta M (1983) The morphogenesis of a papillomatous gastric polyp in the crab-eating monkey (Macaca fascicularis). J Comp Path 93:195-203. 
623. Nelson B, Cogrove GE, Gengozian N (1966) Diseases of an imported primate Tamarinus nigricollis. Lab Anim Care 16:255-275.

624. Nelson EC (1932) The cultivation of a species of Troglodytella, a large ciliate, from the chimpanzee. Science 75:317-318.

625. Nelson GS (1960) Schistosome infections as zoonoses in Africa. Trans Roy Soc Trop Med Hyg 54:301-316.

626. Nelson GS (1965) The parasitic helminths of baboons with particular reference to species transmissible to man. In: Vagtborg $\mathrm{H}$ (ed) The baboon in medical research. University of Texas Press, Austin, TX, pp 441-470.

627. Nelson GS, Teesdale C, Highton RB (1962) The role of animals as reservoirs of bilharziasis in Africa. In: Wolstenholme, O'Conner (eds) Bilharziasis. Ciba Foundation Symposium Bilharziasis, Churchill, London, pp 127-149.

628. Nery-Guimaraes F, Franken AJ, Chagas WA (1971) Toxoplasmose em primates não humanos. I. Infeccões naturais em Macaca mulatta e Cebus apella. Mem Inst Oswaldo Cruz 69:77-96.

629. Newstead R (1906) On another new Dermanyssid Acarid parasitic in the lungs of the rhesus monkey (Macaca rhesus). Mem Lpool Sch Trop Med 18:45.

630. Newstead R, Todd JL (1906) On a new dermanyssid acarid found living in the lungs of monkeys (Cercopithecus schmidti) from the upper Congo. Mem Lpool Sch Trop Med 18:41-44.

631. Nicholas WL (1967) The biology of acanthocephala. Adv Parasitol 5:205-246.

632. Nielsen DH (1980) Prosthenorchis elegans infection in a primate colony. Amer Assoc Zoo Vet Ann Proc, pp 113-116.

633. Nigi H, Itakura C (1968) Spontaneous toxoplasmosis in Lemur catta. Primates $9: 155-160$.

634. Noda S (1962) Comparative studies on morphology of free-living stages of Strongyloides parasitic in monkeys. Jap J Parasitol 11:207-229.

635. Nonoyama T, Sugitani T, Orita S, Miyajima H (1984) A pathological study in cynomolgus monkeys infected with Edesonfilaria malayensis. Lab Anim Sci 34:604-609.

636. Nouvell J, Prot-Lassele J (1963) Shigella dysenteriae 2 chez des chimpanzé en captivité. Bull Acad Vét Fr 36:373-379.

637. Nuttal GHF, Warburton C (1915) The genus Haemaphysalis. In: Ticks, a monograph of the Ixodoidea, part III. Cambridge University Press, pp 349-550.

638. Offutt EP Jr, Telford IR (1945) Sarcocystis in the monkey. A report of two cases. J Parasitol Suppl 21:15.

639. Ogata T, Imai H, Coulston F (1971) Pulmonary acariasis in rhesus monkeys: electron microscopic study. Exp Mol Pathol 15:137.

640. O'Grady JP, Yeager CH, Esra GN, Thomas W (1982) Ultrasonic evaluation of echinococcosis in four lowland gorillas. JAVMA 181:1348-1350.

641. Ogunsusi RA, Mohammed AN (1978) The chimpanzee (Pan troglogdytes), a new host for nymphal Armilliter armillatus (Pentastomida:Porocephalida) in West Africa. Revue d'Elevage et de Med Vet Des Pays Trop 1:361-362.

642. Orihel TC (1966) Brugia tupaiae sp. n. (Nematoda:Filarioidea) in tree shrews (Tupaia glis) from Malaysia. J Parasitol 52:162-165.

643. Orihel TC (1970) Primates as models for parasitological research. In: Goldsmith EI, Moor-Jankowski J (eds) Medical primatology. S Karger, Basel, pp 772-782.

644. Orihel TC (1970) Anatrichosomiasis in African monkeys. J Parasitol 56:982-985.

645. Orihel TC (1970) The helminth parasites of nonhuman primates and man. Lab Anim Care 20:395-401.

646. Orihel TC (1970) Filariasis in chimpanzees. In: Bourne GH (ed) The chimpanzee, vol 3. University Park Press, Baltimore, pp 56-70.

647. Orihel TC (1971) Necator americanus infection in primates. J Parasitol 57:117-121.

648. Orihel TC, Esslinger JH (1973) Meningonema peruzzii gen. et sp. n. (Nematoda: 
Filarioidea) from the central nervous system of African monkeys. J Parasitol 59:437-441.

649. Orihel TC, Seibold HR (1971) Trichospirurosis in South American monkeys. J Parasitol 57:1366-1368.

650. Orihel TC, Seibold HR (1972) Nematodes of the bowel and tissues. In: Fiennes RNT-W (ed) Pathology of simian primates. Part II. Infectious and parasitic diseases. S Karger, Basel, pp 76-103.

651. Ortlepp RJ (1924) On a collection of helminths from Dutch Guiana. J Helminthol 2:15.

652. Otsuru M, Sekikawa H (1968) A survey of simian malaria in Japan. Trans Roy Soc Trop Med Hyg 62:558-561.

653. Oudemans AC (1935) Kritische Literaturübersicht zur Gattung Pneumonyssus. Beschreibung dreier Arten, darunter einer neuen. Z Parasitenk 7:466-512.

654. Owen D, Casillo S (1973) A preliminary survey of the nematode parasites of some imported Old-World monkeys. Lab Anim 7:265-269.

655. Ow-Yang CK, Wah MJ (1975) A remarkable trematode from the parotid gland of Tupaia glis. Southeast Asian J Trop Med Publ Health 6:449.

656. Padovan D, Cantrell C (1983) Causes of death of infant rhesus and squirrel monkeys. JAVMA 183:1182-1184.

657. Palmieri JR, Krishnasamy M (1978) Phaneropsolus aspinosus sp. n. (Lecithodendriidae Phaneropsoline) from leaf monkey Macaca fascicularis (Raffles). J Helminthol 52:155-158.

658. Palmieri JR, Krishnasamy M, Sullivan JT (1977) Helminth parasites of the Old World leaf monkey Presbytis sp. from west Malaysia. Southeast Asian J Trop Med Publ Health 8:409.

659. Palmieri JR, Purnomo, Dennis DT, Marwoto HA (1980) Filarid parasites of South Kalimantan (Borneo) Indonesia. Wuchereria kalimantani sp. n. (Nematoda:Filarioidea) from the silvered leaf monkey, Presbytis cristatus Eschscholtz 1921. J Parasitol 66:645-651.

660. Palmieri JR, Purnomo, Lee VH, Dennis DT, Marwoto HA (1980) Parasites of the silvered leaf monkey, Presbytis cristatus Eschscholtz 1921, with a note on a Wuchereria-like nematode. J Parasitol 66:170-171.

661. Palmieri JR, Dalgard DW, Conner DH (1984) Gastric amebiasis in a silvered leaf monkey. JAVMA 185:1374-1375.

662. Palmieri JR, Van Dellen AF, Tirtokusumo S, Masbar S, Rusch J, Connor DH (1984) Trapping, care, and laboratory management of the silvered leaf monkey (Presbytis cristatus). Lab Anim Sci 34:194-197.

663. Palotay JL, Uno H (1975) Hydatid disease in four nonhuman primates. JAVMA 167:615-618.

664. Parker GA, Gilmore CJ, Roberts CR (1979) Diagnostic exercise. Lab Anim Sci 29:457-458.

665. Patten RA (1939) Amoebic dysentery in orang-utans (Simia satyrus). Aust Vet J 15:68-71.

666. Paulicki A (1872) Beiträge zur vergleichenden pathologischen Anatomie aus dem Hamburger Zoologischen Garten II. Grüne Psorospermienheerde in der Affenlunge. Magges Thierheilk 38:1.

667. Pavor ML (1965) Lung mites (Pneumonyssus simicola) in the feces of Macaca mulatta. Lab Primate Newslett 4:4.

668. Peddie JF, Larson EJ (1971) Demodectic acariasis in a woolly monkey. Vet Med/Sm Anim Clin 66:485-488.

669. Peel E, Chardome M (1946) Note préliminaire sur des filaridès de chimpanzés, Pan paniscus et Pan satyrus au Congo Belge. Rec Sci Méd Congo Belge 5:244.

670. Peel E, Chardome M (1946) Sur des filaridés de chimpanzés "Pan paniscus" et "Pan satyrus" au Congo Belge. Ann Soc Belge Med Trop 26:117-156. 
671. Peel E, Chardome M (1947) Note complémentaire sur des filaridés de chimpanzés, Pan paniscus et Pan satyrus Congo Belge. Ann Soc Belge Méd Trop 27:241250.

672. Penner LR (1981) Concerning threadworm (Strongyloides stercoralis) in great apes-lowland gorillas (Gorilla gorilla) and chimpanzees (Pan troglodytes). J Zoo Anim Med 12:128-131.

673. Phillipe J (1948) Note sur les gales du singe. Bull Soc Path Exot 41:597-600.

674. Pietrzyk J, Uminski J (1967) Malaria u malp Cercopithecus wywolana prezez Hepatocystis kochi. Zwierzeta Lab 2:72-79.

675. Pillers AWN (1921) Sarcoptic scabies (or itch) in the chimpanzee. Brit Vet J 77:329-333.

676. Pillers AWN (1924) Ascaris lumbricoides causing fatal lesions in a chimpanzee. Ann Trop Med Parasitol 18:101-102.

677. Pillers AWN, Southwell T (1929) Strongyloides of the woolly monkey (Lagothrix humbodti). Ann Trop Med Parasitol 23:129.

678. Poelma FG (1966) Eimeria lemuris n. sp., E. galago n. sp. and E. otolicni n. sp. from a galago Galago senegalensis. J Protozool 13:547-549.

679. Poelma FG (1975) Pneumocystis carinii infections in zoo animals. Z Parasitenk 46:61-68.

680. Poindexter HA (1942) A study of the intestinal parasites of the monkeys of the Santiago Island primate colony. Puerto Rico J Publ Health Trop Med 18:175-191.

681. Poisson R (1953) Sous-ordre des hémosporidies (Haemosporidiidea Danilewsky, 1889 emend.; Doflein, 1901). In: Grassé PP (ed) Traité de Zoologie anatomiesystématique biologie, vol I, fasc II. Masson, Paris, pp 798-906.

682. Pope BL (1966) Some parasites of the howler monkey of northern Argentina. J Parasitol 52:166-168.

683. Pope BL (1968) XV. Parasites. In: Malinow MR (ed) Biology of the howler monkey (Alouatta caraya). Bibl Primat. No 7. S Karger, Basel, pp 204-208.

684. Porter A (1945) Report of the honorary parasitologist for 1944. Proc Zool Soc London 115:384-386.

685. Porter A (1952) Chilomastix tarsii sp. n., a new flagellate from the gut of Tarsius carbonarius. Proc Zool Soc London 121:915.

686. Porter A (1953-1954) Report of the honorary parasitologist for the year 1952. Proc Zool Soc London 123:253-257.

687. Porter A (1954) Report of the honorary parasitologist for the year 1953. Proc Zool Soc London 124:313-316.

688. Porter A (1955) Summary of the report of the honorary parasitologist for the year 1954. Proc Zool Soc London 125:541.

689. Porter JA Jr (1972) Parasites of marmosets. Lab Anim Sci 22:503-506.

690. Porter JA Jr, Johnson CM, DeSousa L (1966) Prevalence of malaria in Panamanian primates. J Parasitol 52:669-670.

691. Powers RD, Price RA, Houk RP, Mattlin RH (1966) Echinococcosis in a drill baboon. JAVMA 149:902-905.

692. Prathap K, Law KS, Bolton JM (1969) Pentastomiasis. A common finding at autopsy among Malaysian aborigines. Amer J Trop Med Hyg 18:20-27.

693. Price DL (1959) Dirofilaria magnilarvatum n. sp. (Nematoda:Filarioidea) from Macaca irus Cuvier. I. Description of the adult filarial worms. J Parasitol 45:499-504.

694. Prine JR (1968) Pancreatic flukes and amoebic colitis in a gorilla. Abst 50 19th Ann Meeting Amer Assoc Lab Animal Sci, Las Vegas, 1968.

695. Prosl H, Tamer A (1979) The parasite fauna of the rhesus monkey (Macaca mulatta) and the Java ape (Macaca irus). Zentralbl Veterinärmed 26B:696-709.

696. Pryor WH Jr, Bergner JF, Raulston GL (1970) Leech (Dinobdella ferox) infection of a Taiwan monkey (Macaca cyclopis). JAVMA 157:1926-1927. 
697. Pucak GJ, Johnson DK (1972) Sarcocystis in a Patas monkey (Erythrocebus patas). Lab Anim Dig 8:36-39.

698. Purvis AJ, Ellison IR, Husting EL (1965) A short note on the findings of schistosomes in baboons (Papio rhodesiae). Central African J Med 11:368.

699. Railliet A, Henry A (1909) Sur la classification des Strongylidae. I. Metastrongylinae. CR Soc Biol 66:85-88.

700. Railliet A, Marullaz M (1919) Sur un cénure nouveau du bonnet chinois (Macacus sinicus). Bull Soc Path Exot 12:223-228.

701. Railliet A, Henry A, Joyeux C (1912) Sur deux trématodes de primates. Bull Soc Path Exot 5:833-837.

702. Ramakrishnan SP, Mohan BN (1961) Simian malaria in the Nilgiris, Madras State, India. Bull Natl Soc Ind Malar Mosquito Dis 9:139-140.

703. Ramakrishnan SP, Mohan BN (1962) An enzootic focus of simian malaria in Macaca radiata radiata Geoffrey of Nilgiris, Madras State, India. Ind J Malariol 16:87-94.

704. Ratcliffe HL (1931) A comparative study amoebiasis in man, monkeys and cats, with special reference to the formation of the early lesions. Amer J Hyg 14:337352.

705. Ratcliffe HL (1942) Deaths and important diseases. Rep Penrose Res Lab, pp 11-25.

706. Ratcliffe HL (1955) Causes of death in the animal collection. Rep Penrose Res Lab pp 6-16.

707. Ratcliffe HL (1962) Causes of death in the animal collection. Rep Penrose Res Lab Zool Soc Philadelphia, 1961, 6-18.

708. Ratcliffe HL (1963) Causes of death in the animal collection. Rep Penrose Res Lab Zool Soc Philadelphia, 1962, 13-24.

709. Ratcliffe HL, Worth CB (1951) Toxoplasmosis of captive wild birds and mammals. Amer J Path 27:655-667.

710. Raulston GL (1972) Psorergatic mites in patas monkeys. Lab Anim Sci 22:107-108.

711. Rawling CA, Splitter GA (1973) Pneumothorax associated with lung mite lesions in a rhesus monkey. Lab Anim Sci 23:259-261.

712. Reardon LV, Rininger BF (1968) A survey of parasites in laboratory animals. Lab Anim Care 18:577-580.

713. Reichenow E (1917) Parásitos de la sangre y del intestino de los monos antropomorfos africanos. Bol Real Soc Espan Hist Nat Secc Biol 17:312-332.

714. Reichenow E (1949-1953) Lehrbuch der Protozoenkunde, 6th ed, 3 vol. Fischer, Jena.

715. Reid WA, Reardon MJ (1976) Mesocestoides in the baboon and its development in laboratory animals. J Med Primatol 5:345-352.

716. Remfry J (1982) The endoparasites of rhesus monkeys (Macaca mulatta) before and after capture. Microbiologica 5:143-147.

717. Renquist DM, Johnson AJ, Lewis JC, Johnson DJ (1975) A natural case of Schistosoma mansoni in the chimpanzee (Pan troglodytes). Lab Anim Sci 25:763-768.

718. Rewell RE (1948) Diseases of tropical origin in captive wild animals. Trans Roy Soc Trop Med Hyg 42:17-36.

719. Reyes E (1970) Iodamoeba wallacei $\mathrm{n}$. sp. of amoeba found in Cercopithecus diana L. (Mammalia-Primate) (Sarcodina-Endamoebidae) Bol Soc d Biol Concepcion 42:215-256.

720. Richart R, Benirschke K (1963) Causes of death in a colony of marmoset monkeys. J Path Bacteriol 86:221-223.

721. Richter CB, Humason GL, Godbold JH Jr (1978) Endemic Pneumocystis carinii in a marmoset colony. J Comp Path 88:171-180.

722. Rijpstra AC (1967) Sporocysts of Isospora sp. in a chimpanzee (Pan troglodytes, L.). Proc Kon Nederl Akad Wet 70:395-401.

723. Riopelle AJ, Daumy OJ (1962) Care of chimpanzees for radiation studies. Proc Int 
Symp Bone Marrow Therapy and Chemical Protection in Irradiated Primates. Aug 15-18, 1962. Rijswijk, The Netherlands, pp 205-223.

724. Riopelle AJ (1967) The chimpanzee. In: UFAW Staff (ed) UFAW handbook on the care and management of laboratory animals, 3rd ed. Livingstone and the Universities Federation for Animal Welfare, London, pp 696-708.

725. Robertson OH, Loosli CG, Puck TT, Wise H, Lemon HM, Lester W Jr (1947) Tests for the chronic toxicity of propylene glycol and triethylene glycol on monkeys and rats by vapor inhalation and oral administration. J Pharmacol Exp Therap 91:52-76.

726. Rodaniche de ED (1954) Spontaneous toxoplasmosis in the whiteface monkey, Cebus capucinus, in Panama. Amer J Trop Hyg 3:1023-1025.

727. Rodhain J (1933) Sur une coccidie de l'intestin de l'ouistiti: Hapale jacchus penicillatus (Geoffroy). CR Soc Biol 114:1357-1358.

728. Rodhain J (1941) Notes sur Trypanosoma minansense Chagas: identité spécifique du trypanosome du saimiri: Chrysothrix sciureus. Acta Biol Belg 1:187-193.

729. Rodhain J (1941) Sur un Plasmodium du gibbon Hylobates leusciscus Geoff. Acta Biol Belg 1:118-123.

730. Rodhain (1948) Contribution á l'étude des Plasmodiums des anthropoides africains. Transmission du Plasmodium malariae de l'homme au chimpanzé. Ann Soc Belge Med Trop 28:39-49.

731. Rodhain J, Dellaert R (1943) L'infection á Plasmodium malariae du chimpanzé chez l'homme. Étude d'une premiére souche isolée de l'anthropoide Pan satyrus verus. Ann Soc Belge Med Trop 23:19-46.

732. Rodhain J, Dellaert R (1955) Contribution á l'etude de Plasmodium schwetzi E. Brumpt. II. Transmission du Plasmodium schwetzi á l'homme. Ann Soc Belge Med Trop 35:73-76.

733. Rodhain J, van den Berghe L (1936) Contribution á l'etude des Plasmodiums des singes africains. Ann Soc Belge Med Trop 16:521-531.

734. Rodhain J, van den Berghe L (1939) Paraloa anthropopitheci genre et espéce nouveaux de Filaroidea chez le chimpanzé du Congo Belge. Ann Soc Belge Med Trop $19: 445$.

735. Rodhain J, Wanson M (1954) Un nouveau cas de coenurose chez le babouin (Theropithecus gelada Ruppell). Riv Parassitol 15:613-620.

736. Ronald NC, Wagner JE (1973) Pediculosis of spider monkeys: a case report with zoonotic implications. Lab Anim Sci 23:872-875.

737. Rosen S, Hono JE, Barry KG (1968) Malarial nephropathy in the rhesus monkey. Arch Pathol 85:36-44.

738. Ross PH (1905) A note on the natural occurrence of piroplasmosis in the monkey (Cercopithecus). J Hyg 5:18-23.

739. Rousselot R (1956) Hepatite filarienne des anthropides. Bull Soc Path Exot 49:301-303.

740. Rousselot R, Pellissier A (1952) Pathologie du gorille. III. Oesophagostomose nodulaire a Oesophagostomum stephanostomum du gorille et du chimpanzé. Bull Soc Path Exot 45:568-574.

741. Rowland Eloise, Vandenbergh JG (1965) A survey of intestinal parasites in a new colony of rhesus monkeys. J Parasitol 51:294-295.

742. Ruch TC (1959) Diseases of laboratory primates. WB Saunders, Philadelphia.

743. Ruiz A, Frenkel JK (1976) Recognition of cyclic transmission of Sarcocystis muris by cats. J Infect Dis 133:409-418.

744. Sachs R, Voelker J (1975) A primate, Mandrillus leucophaeus, as natural host of the African lung fluke Paragonimus africanus in West Cameroon. Tropenmed Parasitol 26:205-206.

745. Sagartz JW, Tingpalapong M (1974) Cerebral cysticercosis in a white-handed gibbon. JAVMA 165:844-845.

746. Sakakibara I (1981) Naturally occurring diseases in cynomolgus monkeys. Jap J Med Sci Biol 34:263-267. 
747. Sakakibara I, Sugimoto Y, Koyama T, Honjo S (1982) Natural transmission of Entamoeba histolytica from mother cynomolgus monkeys (Macaca fascicularis) to their newborn infants under indoor rearing conditions. Exper Anim 31:135138.

748. Salis $\mathrm{H}$ (1941) Studies on the morphology of the $E$. histolytica-like amoebae found in monkeys. J Parasitol 27:327-341.

749. Sambon LW (1910) Porocephaliasis in man. J Trop Med Hyg 13:17-24, 212-217, 258-263.

750. Sambon LW (1922) A synopsis of the family Linguatulidae. J Trop Med Hyg 25:188-206, 391-428.

751. Sambon LW (1924) The elucidation of cancer. J Trop Med Hyg 27:124-174.

752. Sandground JH (1925) Speciation and specificity in the nematode genus Strongyloides. J Parasitol 12:59-80.

753. Sandground JH (1930) Notes and descriptions of some parasitic helminths collected by the expedition. Contrib Dept Trop Med Inst Trop Biol Med 5:462-486.

754. Sandground JH (1933) Report on the nematode parasites collected by the KelleyRoosevelts expedition to Indo-China with descriptions of several new species. I. Parasites of birds. 2. Parasites of mammals. Z Parasitenk 5:542.

755. Sandground JH (1936) On the occurrence of a species of Loa in monkeys in the Belgian Congo. Ann Soc Belge Med Trop 16:273.

756. Sandground JH (1936) Scientific results of an expedition to rain forest regions in Eastern Africa. Bull Mus Comp Zool Harvard 79:343-366.

757. Sandground JH (1937) On a coenurus from the brain of a monkey. J Parasitol 23:482-490.

758. Sandground JH (1938) Some parasitic worms in the helminthological collection of the Museum of Comparative Zöology. 2. A redescription of Tetrapetalonema digitata (Chandler 1929) comb. nov., a filariid parasite of gibbon apes with an enumeration of its congeners. Bull Mus Comp Zool Harv 85:49.

759. Sandosham AA (1950) On Enterobius vermicularis (Linnaeus, 1758) and some related species from primates and rodents. J Helminthol 24:171-204.

760. Sandosham AA (1951) On two helminths from the orang-utan, Leipertrema rewelli, n.g., n. sp. and Dirofilaria immitis (Leidy, 1856). J Helminthol 25:19-26.

761. Sandosham AA (1954) Malaysian parasites. XV. Seven new worms from miscellaneous hosts. Stud Inst Med Res Fed Malaya 26:213-226.

762. Sandosham AA, Wharton RH, Warren M, Eyles DE (1962) Microfilariae in the rhesus monkey (Macaca mulatta) from East Pakistan. J Parasitol 48:489.

763. Sano M, Kino H, deGuzman TS, Ishii AI, Kino J, Tanaka T, Tsuruta M (1980) Studies on the examination of imported laboratory monkey Macaca fascicularis for E. histolytica and other intestinal parasites. Intern J Zoon 7:34-39.

764. Sasa M, Tanaka H, Fukui M, Takata A (1962) Internal parasites of laboratory animals. In: Harris RJC (ed) The problems of laboratory animal disease. Academic, New York, pp 195-214.

765. Sawada I, Kifune T (1974) A new species anoplocephaline cestode from Macaca irus. Jap J Parasitol 23:366-368.

766. Schacher JF (1962) Morphology of the microfilaria of Brugia pahangi and of the larval stages in the mosquito. J Parasitol 48:679-692.

767. Schacher JF (1962) Developmental stages of Brugia pahangi in the final host. J Parasitol 48:693-706.

768. Schad GA, Anderson RC (1963) Macacanema formosana n. g., n. sp. (Onchocercidae:Dirofilariinae) from Macaca cyclopsis of Formosa. Can J Zool 41:797-800.

769. Schiefer B, Loew FM (1978) Amebiasis and salmonellosis in a woolly monkey (Lagothrix). Vet Pathol 15:428-431.

770. Schmidt GD (1972) Acanthocephala of captive primates. In: Fiennes RNT-W (ed) Pathology of simian primates. Part II. Infectious and parasitic diseases. S Karger, Basel, pp 144-156. 
771. Schmidt GD, File S (1977) Tupaiataenia quentini gen. et sp. n. (Anoplocephalidae:Linstowiinae) and other tapeworms from the common tree shrew, Tupaia glis. J Parasitol 63:473-475.

772. Schmidt LH, Greenland R, Genther CS (1961) The transmission of Plasmodium cynomolgi to man. Amer J Trop Med Hyg 10:679-688.

773. Schmidt LH, Greenland R, Rossan R, Genther C (1961) Natural occurrence of malaria in rhesus monkeys. Science 133:753.

774. Schmidt RE (1978) Systemic pathology of chimpanzees. J Med Primatol 7:274-318.

775. Schmidt RE, Prine JR (1970) Severe enterobiasis in a chimpanzee. Path Vet 7:56-59.

776. Schoeb TR (1984) Klossiella sp. infection in a galago. JAVMA 185:1381-1382.

777. Schultz AH (1939) Notes on diseases and healed fractures of wild apes, and their bearing on the antiquity of pathological conditions in man. Bull Hist Med 7:571-582. Cited by Ruch TC (1959) Diseases of laboratory primates. WB Saunders, Philadelphia.

778. Schwetz J (1933) Trypanosomes rares de la région de Stanleyville (Congo belge). Ann Parasitol Hum Comp 11:287-296.

779. Schwetz J (1934) Sur quelques trypanosomes rares de la région de Stanleyville (deuxieme note). Ann Parasitol Hum Comp 12:278-282.

780. Scott HH (1926) Report on the deaths occurring in the Society's gardens during the year 1925. Proc Zool Soc London 97:231-244.

781. Seibold HR, Fussell EN (1973) Intestinal microsporidiosis in Callicebus moloch. Lab Anim Sci 23:115-118.

782. Seibold HF, Wolf RH (1970) American trypanosomiasis in Hylobates pileatus. Lab Anim Sci 20:514-517.

783. Seibold HR, Wolf RH (1971) Toxoplasmosis in Aotus trivirgatus and Callicebus moloch. Lab Anim Sci 21:118-120.

784. Seibold HR, Wolf RH (1973) Neoplasms and proliferative lesions in 1065 nonhuman primate necropsies. Lab Anim Sci 23:533-539.

785. Self JT (1969) Biological relationships of the Pentastomida. A bibliography on the Pentastomida. Exp Parasitol 24:63-119.

786. Self JT (1972) Pentastomiasis host responses to larval and nymphal infections. Trans Amer Micr Soc 91:2-8.

787. Self JT, Cosgrove GE (1968) Penastome larvae in laboratory primates. J Parasitol 54:969.

788. Self JT, Cosgrove GE (1972) Penastomida. In: Fiennes RNT-W (ed) Pathology of simian primates. Part II. Infectious and parasitic diseases. S Karger, Basel, pp 194-204.

789. Seneca H, Wolf A (1955) Trypanosoma cruzi infection in the Indian monkey. Amer J Trop Med Hyg 4:1009-1014.

790. Sen Gupta PC, Ray HN (1955) A cytochemical study of Balantidium coli Malmsten, 1857. Proc Zool Soc India 8:103-110.

791. Shadduck JA, Pakes SP (1978) Protozoal and metazoal diseases. In: Benirschke K, Garner FM, Jones TC (eds) Pathology of laboratory animals, chapter 17, vol II. Springer-Verlag, New York, pp 1587-1696.

792. Shannon RC, Greene CT (1926) A bottfly parasite in monkeys. Zoopathologica $1: 285$.

793. Sheldon WG (1966) Psoregatic mange in the sooty mangabey (Cercocebus torquates atys) monkey. Lab Anim Care 16:276-279.

794. Shiroishi T, Davis J, Warren M (1968) Hepatocystis in white-cheeked gibbon Hylobates concolor. J Parasitol 54:168.

795. Shortt HE, Rao G, Qadri SS, Abraham R (1961) Plasmodium osmaniae, a malaria parasite of an Indian Macaca radiata. J Trop Med Hyg 64:140-143.

796. Sinton JA (1934) A quartan malaria parasite of the lower oriental monkey, Silenus irus (Macaca cynomolgus). Records Malaria Surv India 4:379-410. 
797. Sinton JA, Mulligan HW (1932-1933) A critical review of the literature relating to the identification of the malaria parasites recorded from monkeys of the families Cercopithecidae and Colobidae. Rec Malar Surv Ind 3:357-380, 381-444.

798. Skrjabin KI, Shirhobalova NP, Shults RS (1954) Trichostrongylids of animals and man. In: Skrjabin KI (ed) Essentials of nematodology, vol 3. Acad Sci, USSR. (English edition, Israel Program for Scientific Translations, Jerusalem, 1960.)

799. Slaughter LJ, Bostrom RE (1969) Physalopterid (Abbreviata poicilometra) infection in a sooty mangabey monkey. Lab Anim Care 19:235-236.

800. Slaughter LJ, Dade AW, Chineme C, Andrews EJ (1974) Pentastoma larvae in a squirrel monkey. JAVMA 164:711.

801. Sluiter C, Wellengrebel N, Ihle J (1922) De dierlyke parasieten van den mensch en van onze hursdieren scheltema and holkema. Amsterdam.

802. Sly DL, Toft JD II, Gardiner CH, London WT (1982) Spontaneous occurrence of Angiostrongylus costaricensis in marmosets (Saguinus mystax). Lab Anim Sci 32:286-288.

803. Smetana HF, Oriehel TC (1969) Gastric papillomata in Macaca speciosa induced by Nochtia nochti (Nematoda:Trichostrongyloidea). J Parasitol 55:349-351.

804. Smiley RL, O'Connor BM (1980) Mange in Macaca arctoides (Primates:Cercopithecidae) caused by Cosarcoptes scanloni (Acari:Sarcoptidae) with possible human involvement and descriptions of the adult male and immature stages. Intern J Acarol 6:283-290.

805. Smith WN, Chitwood MB (1954) Anatrichosoma cynamolgi, a new trichurid nematode from monkeys. J Parasitol Suppl 40:12.

806. Smith WN, Chitwood MB (1967) Trichospirura leptostoma gen et sp n (Nematoda: Thelazioidea) from the pancreatic ducts of the white-eared marmoset, Callithrix jacchus. J Parasitol 53:1270-1272.

807. Smith WN, Levy BM (1969) The effects of Trichospirura leptostoma on the pancreas of Callithrix jacchus. Program and Abstracts No 7, p 45, 44th Annual Meeting Amer Soc Path, Washington, DC 1969.

808. Soave OA (1963) Diagnosis and control of common diseases of hamsters, rabbits, and monkeys. JAVMA 142:285-290.

809. Sood ML, Toong R (1973) Streptopharagus guptai n. sp. (Nematoda:Spiruridae) from the rectum of a rhesus macaque Macaca mulatta from India. Zoolog Anz 190:132-136.

810. Soulsby EJL (1965) Textbook of veterinary clinical parasitology, vol I. Helminths. FA Davis, Philadelphia.

811. Soulsby EJL (1968) Helminths, arthropods and protozoa of domesticated animals (Mönnig), 6th ed. Williams and Wilkins, Baltimore.

812. Sousa OE, Rossan RN, Baerg DC (1974) The prevalence of trypanosomes and microfilariae in Panamanian monkeys. Amer J Trop Med Hyg 23:862-868.

813. Stam AB (1960) Fatal ascaridosis in a dwarf chimpanzee. Ann Parasitol Hum Comp 35:675.

814. Stiles CW, Hassall A (1929) Key-catalogue of parasites reported for primates (monkeys and lemurs) with their possible public health importance. Hyg Lab Bull No 152 Public Health Serv, Washington, DC. Cited by Dunn FL (1968) The parasites of Saimiri; in the context of Platyrrhine parasitism. In: Rosenblum, LA, Cooper RW (ed) The squirrel monkey, chapter 2. Academic, New York, pp 31-68.

815. Stiles CW, Nolan MO (1929) Key-catalogue of primates for which parasites are reported. Hyg Lab Bull No 152, Public Health Serv, Washington, DC. Cited by Dunn FL (1968) The parasites of Saimiri; in the context of Platyrrhine parasitism. In: Rosenblum LA, Cooper RW (eds) The squirrel monkey, chapter 2. Academic, New York, pp 31-68.

816. Stokes WS, Donovan JC, Montrey RD, Thompson WL, Wannemacher RW Jr, Rosmiarek H (1983) Acute clinical malaria (Plasmodium inui) in a cynomolgus monkey (Macaca fascicularis). Lab Anim Sci 33:81-85. 
817. Stolz G (1962) Spontaneous lethal toxoplasmosis in a woolly monkey. Schweiz Arch Tierheilkd 104:162-166.

818. Stone WB, Hughes JA (1969) Massive pulmonary acariasis in the pig-tail macaque. Bull Wildl Dis Assoc 5:20.

819. Stone WM (1964) Strongyloides ransomi prenatal infection in swine. J Parasitol 50:568.

820. Stookey JL, Moe JB (1978) The respiratory system. In: Benirschke K, Garner FM, Jones TC (eds) Pathology of laboratory animals, chapter 2, vol I. Springer-Verlag, New York, pp 72-113.

821. Strandtmann RW, Wharton GW (1958) A manual of mesostigmatid mites parasitic on vertebrates. Contrib No 4 Inst Acarology University of Maryland, College Park.

822. Strong JP, McGill HC Jr, Miller JH (1961) Schistosomiasis mansoni in the Kenya baboon. Amer J Trop Med Hyg 10:25-31.

823. Strong JP, Miller JH, McGill HC Jr (1965) Naturally occurring parasitic lesions in baboons. In: Vagtborg $\mathrm{H}(\mathrm{ed}) \mathrm{The}$ baboon in medical research, Univ of Texas Press, Austin, TX, pp 503-512.

824. Stunkard HW (1923) On the structure, occurrence and significance of Athesmia foxi, a liver fluke of American monkeys. J Parasitol 10:71-79.

825. Stunkard HW (1940) The morphology and life history of the cestode, Bertiella studeri. Amer J Trop Med 20:305-333.

826. Stunkard HW (1965) Paratriotaenia oedipomidatis gen. et sp. n. (Cestoda), from a marmoset. J Parasitol 51:545-551.

827. Stunkard HW (1965) New intermediate hosts in the life cycle of Prosthenorchis elegans (Diesing 1851), an acanthocephalan parasite of primates. J Parasitol $51: 645-649$.

828. Stunkard HW, Goss LJ (1950) Eurytrema brumpti Railliet, Henry and Joyeux, 1912 (Trematoda:Dicrocoeliidae), from the pancreas and liver of African anthropoid apes. J Parasitol 36:574-581.

829. Suldey EW (1924) Dysentérie amibienne spontanée chez le chimpanzé (Troglodytes niger). Bull Soc Path Exot 17:771-773.

830. Summers WA (1960) A case of hydatid disease in the rhesus monkey (Macaca mulatta). Allied Vet 31:141-143.

831. Sureau P, Raynaud JP, Lapeire C, Brygoo ER (1962) Premier isolement de Toxoplasma gondii à Madasgascar. Toxoplasmose spontanée et experimentale du Lemur catta. Bull Soc Path Exot 55:357-362.

832. Swellengrebel NH, Rijpstra AC (1965) Lateral-spined schistosome ova in the intestine of a squirrel monkey from Surinam. Trop Geograph Med 17:80-84.

833. Swift HF, Boots RH, Miller CP (1922) A cutaneous nematode infection in monkeys. J Exp Med 35:599-620.

834. Takos MJ, Thomas LJ (1958) The pathology and pathogenesis of fatal infections due to an acanthocephalid parasite of marmoset monkeys. Amer J Trop Med Hyg 7:90-94.

835. Taliaferro WH, Taliaferro LG (1934) Morphology, periodicity and course of infection of Plasmodium brasilianum in Panamanian monkeys. Amer J Hyg 20:1-49.

836. Tanaka H, Fukui M, Yamamoto H, Hayama S, Kodera S (1962) Studies on the identification of common intestinal parasites of primates. Bull Exp Anim 11:111-116.

837. Tanguy Y (1937) La piroplasmose du singe. Ann Inst Pasteur 59:610-623.

838. Taylor AER (1959) Dirofilaria magnilvarvatum Price, 1959 (Nematoda:Filarioidea) from Macaca irus Cuvier. II. Microscopical studies on the microfilariae. J Parasitol 45:505-510.

839. Teare JA, Loomis MR (1982) Epizootic of balantidiasis in lowland gorillas. JAVMA 181:1345-1347.

840. Terrell TG, Stookey JL (1972) Chronic eosinophilic myositis in a rhesus monkey infected with sarcosporidiosis. Pathol Vet 9:266-271. 
841. Thatcher VE, Porter JA Jr (1968) Some helminth parasites of Panamanian primates. Trans Amer Micr Soc 87:186-196.

842. Thézé J (1916) Rapport sur les travaux de l'Institut d'Hygiene et de Bacteriologie. 1914-1915. Bull Soc Path Exot 9:449-469.

843. Thienpont D, Mortelmans J, Vercruysse J (1962) Contribution à l'étude de la Trihuriose du chimpanzé et de son traitement avec la methyridine. Ann Soc Belge Med Trop 2:211-218. Cited by Flynn RJ (1973) Parasites of laboratory animals. Iowa State University Press, Ames, IA.

844. Thornton $H(1924)$ The relationship between the ascarids of man, pig and chimpanzee. Ann Trop Med Parasitol 18:99-100.

845. Tihen WS (1970) Tetrapetalonema marmosete in cotton-topped marmosets, Saguinus oedipus, from the region of San Marcos, Colombia. Lab Anim Sci 20:759-762.

846. Toft JD II ( 1982) The pathoparasitology of the alimentary tract and pancreas of nonhuman primates: a review. Vet Pathol 19(Suppl 7):44-92.

847. Toft JD II, Ekstrom ME (1980) Identification of metazoan parasites in tissue sections. In: Montali RJ, Migaki G (eds) The comparative pathology of zoo animals. Smithsonian Institution Press, Washington, DC, pp 369-378.

848. Toft JD II, Schmidt RE, DePaoli A (1976) Intestinal polyposis associated with oxyurid parasites in a chimpanzee (Pan troglodytes). J Med Primatol 5:360-364.

849. Trapido H, Work TH (1962) Non-human vertebrates and hosts and disseminators of Kyasanur Forest disease. Proc 9th Pacific Sci Cong 17:85-87.

850. Trapido H, Gorerdham MK, Rajagopalan PK, Rebello MJ (1964) Ticks ectoparasitic on monkeys in the Kyasanur Forest disease area of Shimoga District, Mysore State, India. Amer J Trop Med 13:763-772.

851. Travassos LP, Vogelsang EG (1929) Sobre um novo Trichostrongylidae parasito de Maccacus [sic] rhesus. Sci Med Ital 7:509-511.

852. Treadgold CH (1920) On a filaria, Loa papionis n. sp. parasitic in Papio cynocephalus. Parasitology 12:113-115.

853. Troisier J, Deschiens RE (1930) Deux cas d'oxyurose chez le chimpanzé traversée de la paroi intestinale jusgu au peritonine. Ann Parasit 8:562-565.

854. Troisier J, Deschiens RE, Limousin H, Delorme MJ (1928) L'infestation du chimpanzé par un nématode du genre Hépaticola. Ann Inst Pasteur, Paris 42:827-840.

855. Troisier J, Deschiens RE, Limousin H, Delorme MJ (1928) L'infestation du chimpanzé par un nématode du genre Hépaticola. Bull Soc Path Exot 21:211-222.

856. Tuggle BN, Beehler BA (1984) The occurrence of Pterygodermatites nycticebi (Nematoda:Rictulariidae) in a captive slow loris Nycticebus coucang. Proc Helminthol Soc Washington, DC 51:162-163.

857. Uemura E, Houser WD, Cupp CJ (1979) Strongyloidiasis in an infant orangutan (Pongo pygmaeus). J Med Primatol 8:282-288.

858. Uilenberg G, Ribot JJ (1965) Note sur la toxoplasmose des lemuriens (Primates:Lemuridae). Rev Elev Med Pays Trop 18:247-248.

859. Ulrich CP, Henrickson RV, Karr SL (1981) An epidemiological survey of wild caught and domestic born rhesus monkeys (Macaca mulatta) for anatrichosoma (Nematoda:Trichinellida). Lab Anim Sci 31:726-727.

860. Urbain A, Bullier P (1935) Un cas de cénurose conjonctive chez un gelada (Theropithecus gelada) (Ruppel). Bull Acad Nat Med 8:322-324.

861. Urbain A, Nouvel J (1944) Petite enzootic de strongyloidose onservée sur des singes superieurs: gibbons á favoris blancs (Hylobates concolor leucogenis Ogilby) et chimpanzés (Pan troglodytes L.). Bull Acad Vét Fr 17:337-341.

862. Valerio DA, Miller RL, Innes JRM, Courtney KD, Pallotta AJ, Guttmacher RM (1969) Macaca mulatta: management of a laboratory breeding colony. Academic, New York.

863. Van Riper DC, Day PW, Finey J, Prince JR (1966) Intestinal parasites of recently imported chimpanzees. Lab Anim Care 16:360-362. 
864. Van Stee EW (1964) Some observations on the clinical management of the chimpanzee. USAF Sch Aerospace Med (AFSC) Brooks AFB, TX, Tech Doc Rept SAM-TDR 64-45.

865. Van Thiel PH (1926) On some filariae parasitic in Surinam mammals, with the description of Filariopsis asper n. g., n. sp. Parasitology 18:128.

866. Van Thiel PH, Wiegand-Bruss CJE (1945) Présence de Prosthenorchis spirula chez les chimpanzés. Son rōle pathogéne et son dévelopment. Dans Blattella germanica. Ann Parasitol Hum Comp 20:304-320.

867. Vickers JH (1966) Hepatocystis kochi in Cercopithecus monkeys. JAVMA 149:906-908.

868. Vickers JH (1968) Gastrointestinal diseases of primates. In: Kirk RW (ed) Current veterinary therapy. III. Small animal practice. WB Saunders, Philadelphia, pp 393-396.

869. Vickers JH (1969) Diseases of primates affecting the choice of species for toxicologic studies. Ann NY Acad Sci 162:659-672.

870. Vickers JH, Penner LR (1968) Cysticercosis in four rhesus brains. JAVMA 153:868-871.

871. Vitzhum H (1930) Pneumonyssus stammeri ein neuer Lungenparasit. Z Parasitenk 2:595-615.

872. Vogel H (1927) Beiträge zur Anatomie der Gattungen Dirofilaria und Loa. Zbl Bakt I Orig 102:81.

873. Vogel H, Vogelsang EG (1930) Neue Filarien aus dem Orang-utan und der Ratte. Zbl Bakt Abt 1, Orig 117:480-485.

874. Voller A (1972) Plasmodium and hepatocystis. In: Fiennes RNT-W (ed) Pathology of simian primates. Part II. Infectious and parastic diseases. S Karger, New York, pp 57-73.

875. Vuylsteke C, Rodhain J (1938) Dirofilaria schoutedeni n. sp. de Colobus polykomos uelensis. Rev Zool Bot Afr 30:356.

876. Walker AE (1936) Cysticercosis cellulosae in the monkey. A case report. J Comp Path 49:141-145.

877. Walker EL (1913) Experimental balantidiasis. Philip J Sci Sect B 8:333-339.

878. Wallace FG, Mooney RD, Sanders A (1948) Strongyloides fulleborni infection in man. Amer J Trop Med 28:299-302.

879. Wallace GD (1972) Experimental transmission of Toxoplasma gondii by cockroaches. J Infect Dis 126:545-547.

880. Wardle RA, McLeod JA (1952) The zoology of tapeworms. University of Minnesota Press, Minneapolis.

881. Warren MCW, Wharton RH (1963) The vectors of Simian malaria: identity, biology, and geographical distribution. J Parasitol 49:892-904.

882. Warren MCW, Bennett GF, Sandosham AA, Coatney GR (1965) Plasmodium eylesi sp. nov., a tertian malaria parasite from the white-handed gibbon, Hylobates lar. Ann Trop Med Parasitol 59:500-508.

883. Warren MCW, Coatney GR, Skinner JC (1966) Plasmodium jefferyi sp. n. from Hylobates lar in Malaya. J Parasitol 52:9-13.

884. Warren MCW, Shiroishi T, Davis J (1968) A hepatocystis-like parasite of the gibbon. Trans Roy Soc Trop Med Hyg 62:4.

885. Webber WAF (1955) The filarial parasites of primates: a review. I. Dirofilaria and Dipetalonema. Ann Trop Med Parasitol 49:123-141.

886. Webber WAF (1955) The filarial parasites of primates: a review. II. Loa, Protofilaria and Parlitomosa, with notes on incompletely identified adult and larval forms. Ann Trop Med Parasitol 49:235-249.

887. Webber WAF (1955) Dirofilaria aethiops Webber, 1955, a filarial parasite of monkeys. I. The morphology of the adult worms and microfilariae. Parasitology 45:369-377. 
888. Webber WAF (1955) Dirofilaria aethiops Webber, 1955, a filarial parasite of monkeys. III. The larval development in mosquitoes. Parasitology 45:388-400.

889. Webber WAF, Hawking F (1955) The filarial worms Dipetalonema digitatum and $D$. gracile in monkeys. Parasitology 45:401-408.

890. Weidman FD (1923) The animal parasites, their incidence and significance. In: Fox $\mathrm{H}$ (ed) Disease in captive wild mammals and birds: incidence, description, comparison. JB Lippincott, Philadelphia, pp 614-659.

891. Weidman FD (1923) Certain dermatoses of monkeys and an ape. Pemphigus, scabies, sebaceous cyst, local subcutaneous edema, benign superficial blastomycotic dermatosis and tinea capitis and circinata. Arch Dermatol Syphilol 7:289302 .

892. Weinberg M (1906) Kystes vermineux du gros intestin chez le chimpanzé et les singes inférieurs. CR Soc Biol, Paris 60:446-449.

893. Weinberg M (1907) Du rôle des helminthes, des larves d'helminthes, et des larves d'insectes dans la transmission des microbes pathogénes. Ann Inst Pasteur 21:417-442, 533-561. Cited by Ruch TC (1959) Diseases of laboratory primates. WB Saunders, Philadelphia.

894. Weinberg M (1908) Oesophagostomose des anthropoides et des singes inférieurs. Arch Parasitol 13:161-203.

895. Wellde BT, Johnson AJ, Williams JS, Langbehn HR, Sadun EH (1971) Hematologic, biochemical, and parasitologic parameters of the night monkey (Aotus trivirgatus). Lab Anim Sci 21:575-580.

896. Wenrich DH (1933) A species of Hexamita (Protozoa, Flagellata) from the intestine of a monkey (Macacus rhesus). J Parasitol 19:225-229.

897. Wenrich DH (1937) Studies of Iodamoeba bütschlii (protozoa) with special reference to nuclear structure. Proc Amer Phil Soc 77:183-205.

898. Wenrich DH, Nie D (1949) The morphology of Trichomonas wenyoni (Protozoa, Mastigophora). J Morphol 85:519-531.

899. Wenyon CM (1926) Protozoology: a manual for medical men, veterinarians and zoologists. 2 vol Balière. Tindall and Cox, London.

900. Wharton RH (1957) Studies on filariasis in Malaya: observations on the development of Wuchereria malayi in Mansonia (Mansoniodes) longipalpis. Ann Trop Med Parasitol 51:278-296.

901. Wharton RH (1959) Dirofilaria magnilarvatum Price, 1959 (Nematoda:Filarioidea) from Macaca irus Cuvier. IV. Notes on larval development in Mansonioides mosquitoes. J Parasitol 45:513-518.

902. Whitney RA Jr, Kruckenberg JM (1967) Pentastomid infection associated with peritonitis in mangabey monkeys. JAVMA 151:907-908.

903. Whitney RA, Johnson DJ, Cole WC (1967) The subhuman primate: a guide for the veterinarian. Edgewood Arsenal Maryland EASP 100-26.

904. Wigglesworth VB (1932) Exhibition of a new species of sucking louse from a chimpanzee. Proc Zool Soc London 1079.

905. Williams CSF, Murray RE, McGovney RM, Cockrell BY (1973) Adamantinoma in a spider monkey (Ateles fusciceps). Lab Anim Sci 23:273-275.

906. Wilson DA, Day PA, Brummer EG (1984) Diarrhea associated with Cryptosporidium sp. in juvenile macaques. Vet Pathol 21:447-450.

907. Windle DW, Reigle DH, Heckman MG (1970) Physaloptera tumefaciens in the stump-tailed macaque (Macaca arctoides). Lab Anim Care 20:763-767.

908. Witenberg GG (1964) Cestodiases. In: van der Hoeden J (ed) Zoonoses. American Elsevier, New York, pp 649-707.

909. Witenberg GG (1964) Acanthocephala infections. In: van der Hoeden (ed) Zoonoses. American Elsevier, New York, pp 708-709.

910. Wong MM (1970) Procedure in laboratory examination of primates with special reference to necropsy technics. Lab Anim Care 20:337-341. 
911. Wong MM, Conrad HD (1972) Parasite nodules in the macaques. J Med Primatol $1: 156-171$.

912. Wong MM, Conrad HD (1978) Prevalence of metazoan parasite infections in five species of Asian macaques. Lab Anim Sci 28:412-416.

913. Wong MM, Kozak WJ (1974) Spontaneous toxoplasmosis in macaques: a report of four cases. Lab Anim Sci 24:273-278.

914. Woodard JC (1968) Acarous (Pneumonyssus simicola) arteritis in rhesus monkeys. JAVMA 153:905-909.

915. Worms MJ (1967) Parasites of newly imported animals. J Inst Anim Technic 18:39-47.

916. Yamaguti S (1954) Studies on helminth fauna of Japan. Part 51. Mammalian nematodes. V Acta Med Okayama 9:105-121.

917. Yamaguti S (1958) The digenetic trematodes of vertebrates. Vol I. 2 parts. In: Yamaguti S, Systema helminthum. Interscience, New York.

918. Yamaguti S (1959) The cestodes of vertebrates. Vol II. In: Yamaguti S, Systema helminthum. Interscience, New York.

919. Yamaguti S (1961) The nematodes of vertebrates. Vol III. In: Yamaguti S, Systema helminthum. Interscience, New York.

920. Yamaguti S, Hayama S (1961) A redescription of Edesonfilaria malayensis Yeh, 1960 , with remarks on its systematic position. Proc Helminthol Soc Washington, DC 28:83-86.

921. Yamashiroya HM, Reed JM, Blair WH, Schneider MD (1971) Some clinical and microbiological findings in vervet monkeys (Ceropithecus aethiops pygerythrus). Lab Anim Sci 21:873-883.

922. Yamashita J (1963) Ecological relationships between parasites and primates. I. Helminth parasites and primates. Primates 4:1-96.

923. Yeh L-S (1957) On a filarial parasite, Deraïophoronema freitaslenti $\mathrm{n}$. sp. from the giant anteater, Myrmecophaga tridactyla from British Guiana, and a proposed reclassification of Dipetalonema and related genera. Parasitology 47:196-205.

924. Yeh L-S (1960) On a new filarioid worm, Edesonfilaria malayensis gen. et sp. nov. from the long-tailed macaque (Macaca irus). J Helminthol 34:125-128.

925. Yokogawa $S$ (1941) On the classficiation of the plasmodia found in the indigenous monkey (black-leg monkey) of Formosa found by us and previously reported. J Med Assoc Formosa 40:2185-2186.

926. Yorke W, Maplestone PA (1926) The nematode parasites of vertebrates. Blakiston, Philadelphia.

927. Yoshimura K, Hishinuma Y, Sato M (1969) Ogmocotyle ailuri (Price, 1954) in the Taiwanese monkey, Macaca cyclopis (Swinhoe, 1862). J Parasitol 55:460.

928. Young MD (1970) Natural and induced malarias in Western Hemisphere monkeys. Lab Anim Care 20:361-367.

929. Young RJ, Fremming BD, Benson RE, Harris MD (1957) Care and management of a Macaca mulatta monkey colony. Proc Anim Care Panel 7:67-82.

930. Yue MY, Jensen JM, Jorden HE (1980) Spirurid infections (Rictularia sp.) in golden marmosets, Leontopithecus rosalia (syn. Leontideus rosalia) from the Oklahoma City Zoo. J Zool Anim 11:77-80.

931. Yunker CE (1964) Infections of laboratory animals potentially dangerous to man: ectoparasites and other anthropods with emphasis on mites. Lab Anim Care $14: 455-465$.

932. Zarman V (1970) Sarcocystis sp. in the slow loris, Nycticebus coucang. Trans Roy Soc Trop Med Hyg 64:195-196.

933. Zaman V (1972) A trypanosome of the slow loris (Nycticebus coucang). Southeast Asian J Trop Med Publ Health 3:22-24.

934. Zaman V, Goh TK (1968) Isolation of Toxoplasma gondii from the slow loris, Nycticebus coucang. Ann Trop Med Parasitol 62:52-53. 
935. Zaman V, Goh TK (1970) Isolation of Toxoplasma gondii from Malayan tree shrew. Trans Roy Soc Trop Med Hyg 64:462.

936. Ziemann H (1902) Über das Vorkommen von Filaria perstans und von Trypanosomen beim Schimpanse. Arch Schiffs Tropen Hyg 6:362.

937. Zumpt F (1961) The arthropod parasites of vertebrates in Africa south of the Sahara (Ethiopian region), vol 1 (Chelicerata). Pub 5th Afr Inst Med Res 9:1-457.

938. Zumpt F, Till WM (1954) The lung and nasal mites of the genus Pneumonyssus Banks (Acarina:Laelaptidae) with description of two new species from African primates. J Ent Soc So Afr 17:195-212.

939. Zumpt F, Till WM (1955) The mange-causing mites of the genus Psorergates (Acarina:Myobiidae) with description of a new species from a South African monkey. Parasitology 45:269-274.

940. Zwicker GM, Carlton WW (1972) Fluke (Gastrodiscoides hominus) infection in a rhesus monkey. JAVMA 161:702-703. 